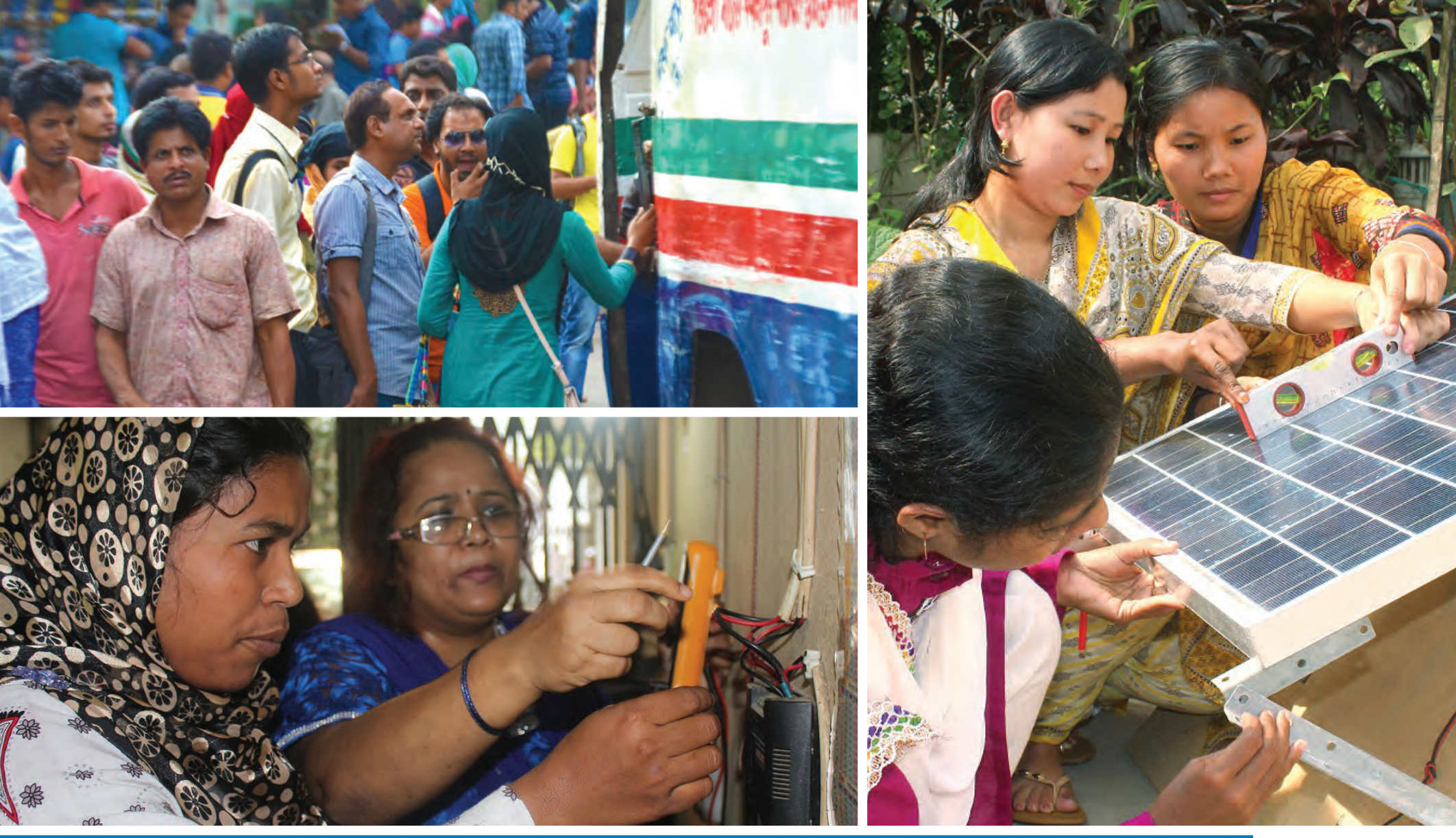

\title{
BANGLADESH \\ GENDER EQUALITY \\ DIAGNOSTIC OF \\ SELECTED SECTORS
}




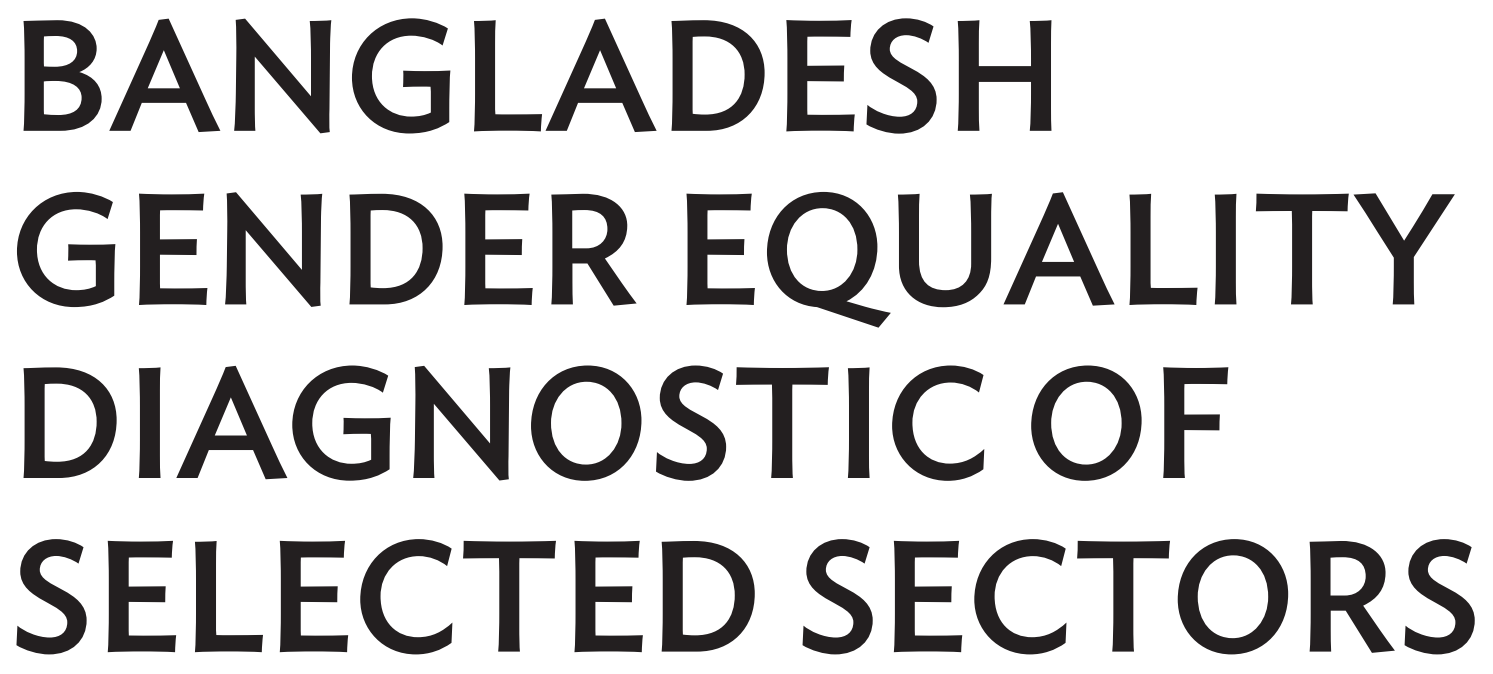


Creative Commons Attribution 3.0 IGO license (CC BY 3.0 IGO)

\author{
(C) 2017 Asian Development Bank \\ 6 ADB Avenue, Mandaluyong City, 1550 Metro Manila, Philippines \\ Tel +632632 4444; Fax +6326362444 \\ www.adb.org
}

Some rights reserved. Published in 2017.

ISBN 978-92-9261-006-7 (Print), 978-92-9261-007-4 (electronic)

Publication Stock No. TCS179121-2

DOI: http://dx.doi.org/10.22617/TCS179121-2

The views expressed in this publication are those of the authors and do not necessarily reflect the views and policies of the Asian Development Bank (ADB) or its Board of Governors or the governments they represent.

ADB does not guarantee the accuracy of the data included in this publication and accepts no responsibility for any consequence of their use. The mention of specific companies or products of manufacturers does not imply that they are endorsed or recommended by $\mathrm{ADB}$ in preference to others of a similar nature that are not mentioned.

By making any designation of or reference to a particular territory or geographic area, or by using the term "country" in this document, $\mathrm{ADB}$ does not intend to make any judgments as to the legal or other status of any territory or area.

This work is available under the Creative Commons Attribution 3.0 IGO license (CC BY 3.0 IGO)

https://creativecommons.org/licenses/by/3.0/igo/. By using the content of this publication, you agree to be bound by the terms of this license. For attribution, translations, adaptations, and permissions, please read the provisions and terms of use at https://www.adb.org/terms-use\#openaccess

This CC license does not apply to non-ADB copyright materials in this publication. If the material is attributed to another source, please contact the copyright owner or publisher of that source for permission to reproduce it. ADB cannot be held liable for any claims that arise as a result of your use of the material.

Please contact pubsmarketing@adb.org if you have questions or comments with respect to content, or if you wish to obtain copyright permission for your intended use that does not fall within these terms, or for permission to use the ADB logo.

Notes:

In this publication, "\$” refers to US dollars.

Photos courtesy of GED consultant-writers, Asma Huque, and Salma A. Shafi.

Corrigenda to ADB publications may be found at http://www.adb.org/publications/corrigenda 


\section{Contents}

Tables, Figures, and Boxes iv

Message-State Minister, Ministry of Women and Children Affairs vi

Message-Director General, South Asia Department, Asian Development Bank vii

Preface-Country Director, Bangladesh Resident Mission, Asian Development Bank viii

Abbreviations $\quad$ ix

Glossary xi

Overview 1

$\begin{array}{ll}\text { Urban Sector } & 15\end{array}$

Transport Sector $\quad 35$

Energy Sector $\quad \mathbf{5 7}$

Skills, Vocational, and Tertiary Education Sector $\quad 83$ 


\section{Tables, Figures, and Boxes}

\section{Tables}

1 Bangladesh Progress on Millennium Development Goals 3 and 5 Targets 4

2 Distribution of Employed Women by Education Level, 2005, 2010, and 2013

3 Labor Force Participation Rates according to Selected Individual Characteristics, 1999, 2005, and $2010 \quad 6$

4 Bangladesh Progress on Selected Millennium Development Goals Indicators, $2015 \quad 7$

5 Employed Persons Aged 15 Years and over by Broad Economic Sector, 2013

6 Persons Aged 15 Years and over by Status in Employment 9

7 Urban, Rural, and Slum Values for Selected Indicators of the 2009 Multiple Indicator $\begin{array}{ll}\text { Cluster Survey } & 17\end{array}$

8 Number of Male and Female Students in Major Private Universities of Bangladesh 39

9 National Policies in the Transport Sector 41

10 Bangladesh Transport Projects by ADB Gender Category $\quad 47$

11 Gender Action Plan: Sustainable Rural Infrastructure Improvement Project 48

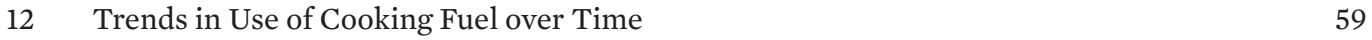

13 Female Participation in Some Fields of Technical Training (Excluding Health and Medical Technology) 64

14 Important Policies and Documents for the Energy Sector and Gender Considerations $\quad 68$

15 Bangladesh Energy Projects by ADB Gender Category $\quad 72$

16 Gross Enrollment, Completion, and Dropout Rates at Secondary Level 86

17 Secondary Cycle Completion Rate, Dropout Rate, and Coefficient of Efficiency by Sex in Secondary Schools, $2014 \quad 87$

18 Number of Secondary School Teachers and Enrollment by Sex, 2011-2015 87

19 Female Enrollment in Technical and Vocational Education Institutions, 201288

20 Number of Teachers and Students by Type of Universities and Sex 89

21 Number of Teachers and Students in Bangladesh University of Engineering and Technology by Sex 90

22 Number of Teachers and Students in the Medical Colleges by Sex 91

23 Bangladesh Education Projects by ADB Gender Category 99

\section{Figures}

$1 \quad$ Male and Female Students in Engineering and Technological Public Universities of Bangladesh 39

2 Bangladesh Transport Sector Agencies and Organizations $\quad 45$

3 Electricity Connection Rate in Rural and Urban Areas, 2014

4 Types of Fuel Used for Cooking in Bangladesh, 2011

5 Organogram of the Power Division of the Ministry of Power, Energy,
and Mineral Resources

\section{Boxes}

$1 \quad$ Administrative Structure and Gender-Related Targets and Quotas $\quad 13$

2 Prevalence of Violence against Women in Urban Contexts 20 
3 Institutionalizing Gender Mainstreaming in Local Government Engineering Department: Gender Equality Strategy and Forum 23

4 Community Mobilization in Urban Slums 24

5 ADB Gender Categorization of Projects $\quad 25$

6 Gender Strategy in the Public Transport System 43

7 Draft Dhaka Structure Plan 2016-2035: Objective-UD 09 (Pedestrian Linkages): Ensuring Walkability in Urban Streets $\quad 44$

8 Bus Rapid Transit Walkability Strategy: Moving Dangerously, Moving Pleasurably 45

9 Public-Private Partnership in Public Transportation Development 47

10 Gender and Energy Framework for the Bangladesh Rural Electrification Board 69

11 Feedback from Women Technicians Trained in Solar Home Systems 70

12 Women in Bangladesh Make Battery-Powered Lamps $\quad 70$

13 Some Definitions for this Chapter $\quad 84$

14 Women-Only Universities $\quad 92$

15 Training of Women Entrepreneurs 93

16 Beijing Platform for Action on Vocational Education 93

17 National Skills Development Council 94 


\section{Message}

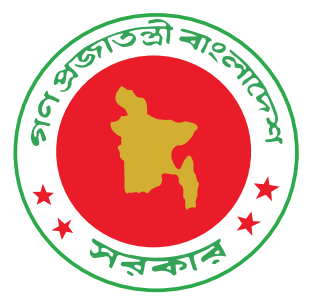

The Asian Development Bank (ADB) has been a valuable multilateral partner of the Government of Bangladesh since 1973. The government appreciates ADB's role in knowledge generation and technical support that accompany its development interventions. It has demonstrated a consistent commitment to promoting gender equality and gender mainstreaming even in sectors where traditionally it has been difficult to do so. This publication entitled Bangladesh: Gender Equality Diagnostic of Selected Sectors is timely as it coincides with the start of the Seventh Five Year Plan and the ADB Country Partnership Strategy (CPS), 2016-2020.

Discrimination against women and girls is a historical and social phenomenon that manifests itself in many ways. Achieving gender equality and women's empowerment is therefore a challenge for all of us. Legislation and policies are important but not sufficient to eliminate gender biases and discrimination. Reducing gender disparities requires the promotion of and support for gender equality in the various interventions and programs that the government undertakes, which also promote changes in attitudes and practices in the government and broader society. This requires long-term commitment and efforts of all development partners, including ADB.

Under the visionary leadership of honorable Prime Minister Sheikh Hasina, Bangladesh has attained mentionable progress in women's empowerment in spite of having few challenges. Now, Bangladesh is considered a role model country in the areas of women's empowerment. Our aim is to achieve the target of Planet $50-50$ by 2030 . We cannot achieve our desired goal unless we emancipate half of the population at par with the other half. So, we are striving to ensure equal opportunity in order to integrate women in the mainstreaming of development.

This publication is a welcome contribution to the government's work by identifying opportunities for and constraints on promoting women's empowerment in urban development, transportation, energy, and skills development. It provides an analysis of institutions, policies, and strategies to mainstream gender; insights into experiences of development initiatives in these sectors; and suggestions for further strengthening of gender equality. The analysis of the Bangladesh: Gender Equality Diagnostic of Selected Sectors has informed the ADB CPS, 2016-2020 and can also be used as a resource to promote and support government agencies and development partners to ensure that gender concerns are addressed in the selected sectors.

I wish to congratulate ADB for bringing out this useful publication and working with the Government of Bangladesh to promote gender equality.

Joy Bangla, Joy Bangabandhu.

May Bangladesh live forever.

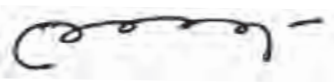

\section{Meher Afroze Chumki MP}

State Minister

Ministry of Women and Children Affairs

Government of the People's Republic of Bangladesh 


\section{Message}

I am pleased to present the Gender Equality Diagnostic of Selected Sectors of the Asian Development Bank (ADB) in Bangladesh. It provides scope for promoting gender equality and women's empowerment, and manifests the commitment of ADB to effectively pursue gender mainstreaming in key sectors of our development work in Bangladesh that have persistent and pressing gender issues-education, energy, transport, and urban development. The institutional context and genderrelated data discussed in each sector chapter will support evidence-based approach in conducting gender analysis, setting achievable baselines and targets for projects, and, ultimately, in accounting for gender equality results. The policies, good practices, and lessons learned in gender mainstreaming will help inform the design of project gender features and related initiatives.

We hope this publication will be a useful resource not only for ADB, but also for our partner government agencies and other development partners in our individual and joint efforts to achieve the gender objectives and targets of the Sustainable Development Goals to bring about significant positive changes in the lives of women and men, and in the promotion of inclusive development.

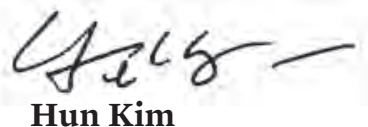

Hun Kim

Director General

South Asia Department

Asian Development Bank 


\section{Preface}

The Bangladesh Gender Equality Diagnostic of Selected Sectors (GEDSS) was produced to support the development objectives of the Government of Bangladesh set out in its Seventh Five-Year Plan (2016-2020), as well as the thrust of the Asian Development Bank (ADB) in promoting inclusive and environmentally sustainable growth as indicated in its Country Partnership Strategy (2016-2020).

The GEDSS is meant to guide the design of the gender features of ADB-supported projects in key sectors-skills, vocational, and tertiary education; energy; transport; and urban development. The gender issues, policies, and institutional contexts underpinning the issues presented in this material help inform gender analysis of projects. Good practices and lessons in gender mainstreaming and other gender mainstreaming approaches presented in the publication provide direction for the development of project-related initiatives to promote gender equality and social inclusion.

ADB extends its gratitude to the individuals and agencies who contributed to the preparation of Bangladesh GEDSS. Overall guidance was provided by Francesco Tornieri, principal social development specialist (gender and development) of ADB South Asia Department and Nasheeba Selim, social development officer (gender) of the Bangladesh Resident Mission. The BRAC Institute of Governance and Development of BRAC University undertook the study. Sector government agencies, private sector organizations, nongovernment organizations (NGOs), academics, researchers, and sectoral staff participated in seven consultations held in Dhaka, Bogra, Chittagong, and Khulna. The comments of ADB headquarters specialists helped shape the final report. Apart from extensive review of existing literature, studies, reports, statistics, and policies in each of the sectors, interviews were also done with key actors from government, NGOs, private sector, and academe in the sectors. The study was presented at a national seminar. The suggestions, insights, and recommendations obtained throughout the process from various stakeholders greatly enriched the report.

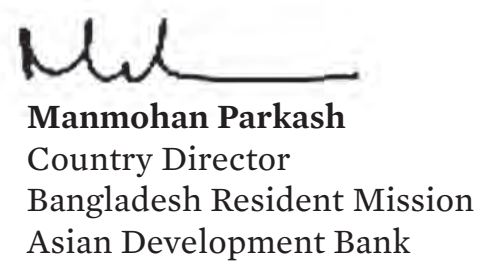




\section{Abbreviations}

\begin{tabular}{|c|c|}
\hline $\mathrm{ADB}$ & Asian Development Bank \\
\hline AKKF & A.K. Khan Foundation \\
\hline ARBAN & Association for Realisation of Basic Needs \\
\hline ASI & avoid-shift-improve \\
\hline BBS & Bangladesh Bureau of Statistics \\
\hline BMET & Bureau of Manpower, Employment and Training \\
\hline BPDB & Bangladesh Power Development Board \\
\hline BRAC & Building Resources Across Communities \\
\hline BREB & Bangladesh Rural Electrification Board \\
\hline BRT & bus rapid transit \\
\hline CLC & community learning center \\
\hline DAM & Dhaka Ahsania Mission \\
\hline EGM & effective gender mainstreaming \\
\hline ENERGIA & International Network on Gender and Sustainable Energy \\
\hline FY & fiscal year \\
\hline GAP & gender action plan \\
\hline GDP & gross domestic product \\
\hline GED & gender equality diagnostic \\
\hline GEN & gender equity theme \\
\hline HSC & higher secondary certificate \\
\hline ICT & information and communication technology \\
\hline IDCOL & Infrastructure Development Company Limited \\
\hline ILO & International Labour Organization \\
\hline $\mathrm{km}$ & kilometer \\
\hline LCS & labor contracting societies \\
\hline LFP & labor force participation \\
\hline LGED & Local Government Engineering Department \\
\hline LPG & liquefied petroleum gas \\
\hline MDG & Millennium Development Goal \\
\hline MFF & multitranche financing facility \\
\hline MOE & Ministry of Education \\
\hline MOWCA & Ministry of Women and Children Affairs \\
\hline MPEMR & Ministry of Power, Energy and Mineral Resources \\
\hline MW & megawatt \\
\hline NGE & no gender elements \\
\hline NGO & nongovernment organization \\
\hline NMT & nonmotorized transport \\
\hline NSDC & National Skills Development Council \\
\hline NSDP & National Skills Development Policy \\
\hline
\end{tabular}




\section{Abbreviations}

$\begin{array}{ll}\text { NTVQF } & \text { National Technical and Vocational Qualifications Framework } \\ \text { PBS } & \text { Palli Bidyut Samity (village electricity associations) } \\ \text { PPP } & \text { public-private partnership } \\ \text { RDA } & \text { Rural Development Academy } \\ \text { RRP } & \text { report and recommendation of the President } \\ \text { SDG } & \text { Sustainable Development Goal } \\ \text { SHS } & \text { solar home system } \\ \text { SMC } & \text { school management committee } \\ \text { SMEs } & \text { small and medium-sized enterprises } \\ \text { SREDA } & \text { Sustainable and Renewable Energy Development Authority } \\ \text { SRIIP } & \text { Sustainable Rural Infrastructure Improvement Project } \\ \text { SSC } & \text { secondary school certificate } \\ \text { STAR } & \text { Skills Training for Advancing Resources } \\ \text { TA } & \text { technical assistance } \\ \text { TQI } & \text { Teaching Quality Improvement } \\ \text { TTC } & \text { technical training center } \\ \text { TVET } & \text { technical and vocational education and training } \\ \text { UGIIP } & \text { Urban Governance and Infrastructure Improvement Project } \\ \text { UNICEF } & \text { United Nations Children's Fund } \\ \text { USAID } & \text { United States Agency for International Development } \\ \text { VAW } & \text { violence against women } \\ \text { WASA } & \text { Water Supply and Sewerage Authority } \\ \text { WID } & \text { women in development } \\ \text { WSS } & \text { water supply and sanitation }\end{array}$




\section{Glossary}

\begin{tabular}{|c|c|}
\hline char & strip of sandy land rising out of a river bed \\
\hline gano kendra & people's center \\
\hline haor & low-lying area which is flooded during certain times of the year \\
\hline hijra & transgender person \\
\hline madrasa & an institution for the study of Islamic theology and religious law \\
\hline mastaan & gangster \\
\hline parishad & council \\
\hline pourashava & municipality \\
\hline purdah & veil \\
\hline upazila & subdistrict \\
\hline zila & district \\
\hline
\end{tabular}





\section{Overview}

\section{Introduction}

The Asian Development Bank (ADB) has been supporting Bangladesh since 1973. As of April 2017, ADB has provided Bangladesh with $\$ 18.3$ billion for 269 loans, \$252.4 million for 422 technical assistance projects, and $\$ 787.10$ million for 35 grants. ${ }^{1}$ The key areas or priority sectors of ADB's support-as defined in the periodic $\mathrm{ADB}$ Bangladesh country partnership strategy (CPS)-are energy security, transport connectivity, education and skills development, water resources management, urban infrastructure, and finance. The periodic CPS contains an overview of gender equality issues in these key sectors and ADB's corresponding strategy in mainstreaming gender in related loan, grant, and TA projects.

To support the formulation of the gender strategy of the Bangladesh CPS (20162020), the ADB South Asia Department (SARD) commissioned a study for a gender diagnostic of four selected sectors, entitled Bangladesh: Gender Equality Diagnostic of Selected Sectors. ${ }^{2}$ These four sectors are (i) urban development (including governance, water supply and sanitation, primary health care, and environmental health including waste management); (ii) transport (especially mobility and gender-related aspects of infrastructure development-national rural and urban roads, railways, and ports-and transport services); (iii) energy (including rural

\footnotetext{
${ }^{1}$ ADB.2017. Asian Development Bank and Bangladesh: Fact Sheet. Manila. https://www.adb.org/ publications/bangladesh-fact-sheet

2 The initial draft (developed in early 2016) of this gender equality diagnostic (GED) of four selected sectors was used as a guide and basis for the formulation of the gender strategy in the ADB Bangladesh Country Partnership Strategy (CPS), 2016-2020. During the finalization of this GED, recent (2016) data were incorporated to produce a more updated report.
}

electrification and renewable energy); and (iv) education (with emphasis on vocational education, skills development, and tertiary education). This technical report presents the results of this gender equality diagnostic (GED).

This GED is aligned with the Seventh Five Year Plan of the Government of Bangladesh, and with the gender equality targets of the United Nations Sustainable Development Goals (SDGs). It provides the government with a tool and platform to advance progress in mainstreaming gender in sector policies, strategies, and programs, in line with the commitments set out in the National Women Development Policy 2011. It also serves as a resource to support government agencies and development partners to mainstream gender equality into its operational sectors. It presents an in-depth analysis of the different areas and forms of discrimination in each sector, and recommends sectorspecific solutions and strategies. The report also provides planners, practitioners, and evaluators with a practical reference for sector analyses, designing projects, monitoring implementation, and engaging in policy dialogue.

\section{Country Context}

Economic growth and poverty reduction. Bangladesh had a population of 144 million in 2011, and a gross domestic product (GDP) of Tk4,337 billion in 2013. With its GDP growing at $6 \%$ or more per year, the country has progressed into a middle-income country status. In general, the country performed well on the United Nations' Millennium Development Goals (MDGs), and has made rapid progress on several social and economic indicators, according to the Human Development Reports (HDRs) 2014-2016 of the UNDP, moving from a low human development category in 2013 to medium human development category 
in 2014 to 2016. It is rapidly urbanizing. Poverty declined from $56.7 \%$ in $1991-1992$ to $31.5 \%$ in 2010 , the rate of reduction being faster in 2005-2015. The Household Income and Expenditure Survey 2010 data shows that the incidence of poverty declined on average 1.74 percentage points. The poverty headcount ratio for 2015 is estimated to be $24.8 \% .^{3}$ Of note is the significant decline in the incidence of extreme poverty between 2005 and 2010. The percentage of population under the lower poverty line, the threshold for extreme poverty, decreased from $25 \%$ of the population in 2005 to $17.6 \%$ in 2010 , a decrease of $29.6 \%{ }^{4}$ The incidence of extreme poverty has also declined by $47 \%$ in urban areas and $26 \%$ in rural areas. ${ }^{5}$ The MDG Progress Report prepared by the General Economics Division of the Planning Commission states that the sharp

3 Government of Bangladesh, Bangladesh Bureau of Statistics. 2015. Household Income and Expenditure Survey 2015. Dhaka.

${ }^{4}$ Measurement of lower poverty line is based on the cost of basic needs method. Since 1995-1996, Bangladesh Bureau of Statistics has been using this as the standard method for estimating the incidence of poverty. In this method, two poverty lines are estimated:

(i) Lower poverty line. The extreme poor households are those households whose total expenditures on food and nonfood combined are equal to or less than the food poverty line.

(ii) Upper poverty line. This is estimated by adding together the food and nonfood poverty lines. The moderate poor households are those households whose total expenditures are equal to or less than the upper poverty line.

A brief description of estimating incidence of poverty using the cost of basic needs method is as follows:

(i) Food poverty line. (a) A basic food basket (11 food items) is selected. (b) The quantities in the basket are scaled according to the nutritional requirement of 2,122 kilocalories per person per day. (c) The cost of acquiring the basket is calculated and taken as the food poverty line.

(ii) Nonfood poverty line. This is calculated by estimating the cost of consuming nonfood items by the households close to the food poverty line. For estimating the poverty incidence with the Household Income and Expenditure Survey 2010 data, several options were tested. Finally, for ensuring comparability and transparency, an option was adopted for estimating poverty incidence that includes (i) updating food poverty lines of 2005 with food price inflation rates calculated from the unit values of survey 2005 data and survey 2010 data, and (ii) reestimating nonfood poverty line using survey 2010 data to adjust to changes in nonfood-food ratios.

${ }^{5}$ Government of Bangladesh, Planning Commission. 2015. Millennium Development Goals: Bangladesh Progress Report 2015. Dhaka. p. 21. increase in rural wage has had the greatest impact on poverty reduction. Due to greater reallocation of labor from farm to nonfarm and from wage labor to own-farm work, the rural labor market has shrunk, resulting in a steep increase in rural wage. ${ }^{6}$ Rural Bangladesh experienced a moderate increase in income inequality (0.39 in 2000 to 0.43 in 2010), although consumption inequality as reflected in the Expenditure Gini remained stable during the same period.?

Beginnings of structural and demographic transformations. The beginnings of a structural transformation in the economy started to manifest over the last 5 years, with the share of the manufacturing sector in GDP increasing slightly, while that of agriculture declining. However, the service sector has remained the dominant contributor to GDP and sustained a similar level of contribution throughout the 1990s and 2000s, and has emerged as the most dynamic sector of the economy. The provisional figures on sector growth rates of GDP for 2014-2015 show that while the average GDP growth rate was $6.5 \%$, it was higher in manufacturing (10.3\%), construction (8.6\%), financial intermediations (8.8\%), and education (8.2\%). Demographically, the country is going through a transition and is expected to benefit from an increasing proportion of the working age group.

Bangladesh's performance compared to its neighboring countries. HDR 2015 of the United Nations Development Programme (UNDP) listed Bangladesh among countries, which registered a rapid human development progress in 2013-2014. From a Human Development Index (HDI) of .515, a rank of 146 (out of 188 countries), and a low human development category in $2013,{ }^{8}$ its HDI rose to .570 with a higher rank of 142 (out of 188 countries), and a medium human development category in 2014. ${ }^{9}$ Its HDI in 2015 further went up to .579 and its rank to $139 .^{10}$

\footnotetext{
${ }^{6}$ Footnote 5 (Bangladesh Progress Report 2015), p. 22.

${ }^{7}$ Footnote 5 (Bangladesh Progress Report 2015), p. 24

${ }^{8}$ UNDP. 2013. Human Development Report 2013. The Rise of the South: Human Progress in a Diverse World. New York.

9 UNDP. 2015. Human Development Report 2015: Work for Human Development. New York.

${ }^{10}$ UNDP. 2016. Human Development Report 2016: Human Development for Everyone. New York.
} 


\section{Progress in the Status of Women}

Significant progress in primary education and maternal health. Bangladesh almost achieved the MDG target of $100 \%$ for universal primary education as the net enrollment ratio increased from $60.5 \%$ in $1991-1992$ to $97.94 \%$ in 2015 , and the survival rate (proportion of pupils who reach Grade 5) increased from $43 \%$ in 1991 to $81.3 \%$ in $2015 .{ }^{11}$ The MDG End Period Stocking and Final Evaluation Report (2000-2015) of Bangladesh did not provide sex-disaggregated data for 2015 , but its data for 2014 show that the net enrollment ratio was $98.8 \%$ for girls and $96.6 \%$ for boys, and the survival rate was $84.45 \%$ for girls and $77.65 \%$ for boys.

On maternal health, though the maternal mortality ratio (deaths per 100,000 live births) of 181 in 2015 was below the MDG 2015 target of 143 , this achievement was considered noteworthy considering its base figure of 472 in 1990-1991 and 318 in 2000. Similarly, while the achieved 42.1 proportion of births attended by skilled health personnel in 2014 was below the MDG 2015 of 50, given its base figure of 5.0 in 1990-1991 and 15.6 in 2000, this achievement could be considered as a significant progress. Nonetheless, the high maternal mortality ratio indicates the need to improve women's access to health care (only $55 \%$ of women have access to antenatal care from a trained provider, and only $32 \%$ of births are assisted by a skilled provider). There is still a high unmet need for contraception and nutrition remains an area of concern (almost 50\% of pregnant women are anemic). ${ }^{12}$ While the overall life expectancy has increased, women's life expectancy of 72.63 is higher than men's life expectancy of $68.75 .^{13}$

${ }^{11}$ S. Allam, ed. 2016. Millennium Development Goals: End-period Stocktaking and Final Evaluation Report (2000-2015). Dhaka: General Economics Division (GED), Bangladesh Planning Commission, Government of Bangladesh.

12 Government of Bangladesh, National Institute of Population Research and Training. 2013. Bangladesh Demographic and Health Survey 2011. Dhaka. p. 121 (services) and p. 189 (anemia).

${ }^{13}$ Because of decreasing age-specific death rates, life expectancy at birth increased for both women and men in urban and rural areas during 1999-2011, but again the increase was relatively more for women-62-70 years compared with 63-68 years
Table 1 shows the detailed achievements of Bangladesh in MDG 3 (promote gender equality and empower women) and MDG 5 (improve maternal health).

Progress in education contributing to progress in employment. The distribution of the employed population by education (Table 2) shows that the proportion of employed women with no formal schooling reduced by half (from $41 \%$ to $21 \%$ ) from 2010 to 2013 , while the proportion with primary level education (grades 1-5) increased considerably. The proportion with higher secondary education increased visibly, and so did the proportion with a bachelor's or higher degree. Thus, the employed female population has become more skilled over the years, with education level used as a measure of skill. Table 3 shows the individual characteristics of women and men in the labor force. It shows that women's labor force participation (LFP) rate is highest in the age group 25-44, highest among married women (38\%), and highest for women with university degrees or technical or vocational education.

However, the situation regarding women's access to technical and vocational training is less positive. There are gender disparities in enrollments-only $28 \%$ of students enrolled in technical and vocational training are females, and proportions are particularly low in the public sector educational institutions, as opposed to private institutions or nongovernment organizations (NGOs). ${ }^{14}$ Women's limited presence in technical and vocational training is one of the many factors that influence their employment patterns.

Increasing women's labor force participation. As shown in Table 4, women's LFP rates increased faster than men's - from $26.1 \%$ in $2002-2003$ to $33.5 \%$ in 2013, while men's LFP rates decreased from $87.4 \%$ to $81.7 \%$ during the same period. ${ }^{15}$ All the same, compared with

for men. See Government of Bangladesh, Bangladesh Bureau of Statistics. 2014. Statistical Pocketbook of Bangladesh 2013. Dhaka.

${ }^{14}$ Bangladesh Bureau of Educational Information and Statistics (BANBEIS). Educational Database. Summary Statistics and KPI-2013. Table 7.1. http:// data.banbeis.gov.bd/index.php?option=com_cont ent\&view=section\&id=36\&Itemid=225 (accessed 11 December 2016).

15 Government of Bangladesh, Bangladesh Bureau of Statistics. 2013. Labour Force Survey 2013. Dhaka. 
Table 1: Bangladesh Progress on Millennium Development Goals 3 and 5 Targets

Goals, Targets, and Indicators

Base Year Status

1990-1991 in 2000

Current Status

(Source)

Target

by 2015

Goal 3: Promote Gender Equality and Empower Women

Target 3.A: Eliminate gender disparity in primary and secondary education, preferably by 2005, and in all levels of education no later than 2015

3.1a: Ratio of girls to boys in Primary education (Gender Parity Index = Girls/Boys

\begin{tabular}{l|l|}
0.83 & 0.96 \\
& \\
&
\end{tabular}

1.04 (APSC, 2015, DPE)

1.07 (MICS 2012-2013)

1.10 (BDHS 2011)

3.1b: Ratio of girls to boys in secondary education (Gender Parity Index = Girls/Boys)

3.1c: Ratio of girls to boys in tertiary education (Gender Parity Index $=$ Girls/Boys)

3.2: Share of women in wage employment in the nonagricultural sector, \%

3.3: Proportion of seats held by women in national parliament, \%

0.52

0.37

1.06

1.14 (BANBEIS 2015)

1.30 (MICS 2012-2013)

$0.33 \quad 0.65$ (BANBEIS, 2015)

0.78 (UGC 2013)

19.10

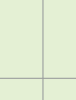

12.70

$\mid$

22.00

13.03

31.6 (LFS 2013)

20.29 (BPS 2015)

\section{Goal 5. Improve Maternal Health}

Target 5.A: Reduce by three quarters, between 1990 and 2015, the maternal mortality ratio

5.1: Maternal mortality ratio (per 100,000 live births)

472

318

170 (MMEIG 2013)

181 (SVRS 2015)

194 (BMMS 2010)

5.2: Proportion of births attended by skilled health personnel (\%)

5.0

$15.6 \quad 42.1$ (BDHS 2014)

43.5 (MICS 2012-2013)

Target 5.B: Achieve, by 2015, universal access to reproductive health

5.3: Contraceptive prevalence rate, $\%$

53

62.4 (BDHS 2014)

61.8 (MICS 2012-2013)

(CPS 1991)

62.1 (SVRS 2015)

5.4: Adolescent birth rate, (per 1,000 women)

79

39

83 (MICS 2012-2013)

113 (BDHS 2014)

(1990 SVRS)

75 (SVRS 2015)

5.5: Antenatal care coverage (at least one visit and at least four visits) (\%)

5.5a: Antenatal care coverage (at least one visit), \%

5.5b: Antenatal care coverage (at least four visits), \%

5.6: Unmet need for family planning, \%

\begin{tabular}{c|c} 
& \\
& \\
27.5 & 50.6 \\
$(1993-1994)$ & $(2004)$ \\
5.5 & 16.7 \\
$(1993-1994)$ & $(2004)$ \\
21.6 & 18.2 \\
$(1993-1994)$ & \\
\hline
\end{tabular}

\begin{tabular}{|l}
78.6 (BDHS 2014) \\
58.7 (MICS 2012-2013) \\
31.2 (BDHS 2014) \\
24.7 (MICS 2012-2013) \\
13.9 (MICS 2012-2013) \\
12.0 (BDHS 2014)
\end{tabular}

100

APSC = Annual Primary School Survey, BANBEIS = Bangladesh Bureau of Educational Information and Statistics, BDHS = Bangladesh Demographic and Health Survey, BPS = Bangladesh Parliament Secretariat, DPE = Department of Primary Education, LFS = Labour Force Survey, $\mathrm{MDG}=$ Millennium Development Goals, MICS=Multiple Indicator Cluster Survey, MMEIG = Maternal Mortality Estimation Inter-Agency Group.

Source: S. Allam, ed. 2016. Millennium Development Goals: End-period Stocktaking and Final Evaluation Report (2000-2015). Dhaka: General Economics Division (GED), Bangladesh Planning Commission, Government of Bangladesh.

men, women have lower LFP rates, higher unemployment rates, and much higher underemployment rates. ${ }^{16}$ For both women and men, LFP rates are higher in the rural areas than in the urban areas-23.4\% in

\footnotetext{
${ }^{16}$ International Labour Organization. 2012. Bangladesh: Decent Work Country Programme 2012-2015.
}

urban areas and $76.6 \%$ in rural areas in 2013. The figures are roughly similar for men and women.

Increasing women's wages. Women's wages have increased much faster than men's wages since 2000, and the gender gap in income and wages has narrowed considerably. The structure of monthly 


\begin{tabular}{|c|c|c|c|}
\hline Item & 2005 & 2010 & 2013 \\
\hline Total women employed ('000) & $11,277.00$ & $16,202.00$ & $16,846.00$ \\
\hline \multicolumn{4}{|l|}{ Education (\%) } \\
\hline No schooling & 52.00 & 41.30 & 21.40 \\
\hline Primary & 23.10 & 22.90 & 34.70 \\
\hline Secondary (includes SSC) & 19.80 & 31.10 & 29.30 \\
\hline Higher secondary (includes HSC) & 2.10 & 2.60 & 10.40 \\
\hline Tertiary & 2.90 & 2.00 & 3.90 \\
\hline Technical or vocational & 0.10 & 0.07 & - \\
\hline Others & 0.05 & 0.03 & 0.40 \\
\hline Total & & 100.00 & 100.00 \\
\hline
\end{tabular}

income of women and men shows that in $2000,78.2 \%$ of the women workers and $39.5 \%$ of the men workers were earning less than Tk2,000 per month. In 2010, this declined to $4.6 \%$ of the women workers and $1.6 \%$ of the men workers. At the highest income level in $2000,0.7 \%$ of the women workers and $2.2 \%$ of the men workers were earning more than Tk10,000 per month, whereas in 2010, $23.8 \%$ of the women workers (34 times increase) and $34.8 \%$ of the men workers (15.8 times increase) were in this earning category. The data from the Labour Force Survey 2013 shows that the average monthly income from employment was Tk11,621 for men and Tk11,136 for women, with a wider wage gap in urban areas (Tk14,186 for men and Tk12,312 for women) compared with rural areas (Tk10,304 for men and Tk10,264 for women). ${ }^{17}$ Education appears to be a critical factor.

Unfavorable terms of women's participation in labor market. The terms of women's participation in the labor market remain discriminatory. While there is some increase in numbers employed in the formal sectors, there is a larger percentage increase in the informal sector such as home-based work. The informal sector employs more labor than the formal

\footnotetext{
${ }^{17}$ Government of Bangladesh, Bureau of Statistics. 2000. Labour Force Survey 1999-2000, 2002-2003, 2005-2006, 2010, 2013. Dhaka;
}

sector: $86.9 \%$ of the total labor force is employed in the informal sector. More men than women are working in the formal sector: $9.7 \%$ of women are in the formal sector, and $90.3 \%$ in the informal sector. Rural-urban variations also exist: in the urban areas, $25.7 \%$ of employment is in the formal sector, while $74.3 \%$ is in the informal sector. On the other hand, in rural areas, $8.3 \%$ women are employed in the formal sector, while $91.7 \%$ are in the informal sector. ${ }^{18}$ Women are overrepresented in both the informal and rural sectors, which are by lower returns, greater insecurity, and generally unfavorable working conditions. This shows the relative unfavorable terms of women's engagement in the labor market.

As shown in Table 5, in 2013, 53.5\% of women were in agriculture, $23.7 \%$ in industry, and $22.8 \%$ in services. In 2013, the highest percentage $(41.7 \%)$ of men were engaged in agriculture, followed closely by services (38.7\%) and industry (19.6\%). Employed women remain more concentrated in agriculture than men, which suggests that women have more limited access to sectors with greater return to their labor.

Gender differences in employment status. Gender differences exist in the status of employment. As shown in Table 6, the highest percentage of employed persons were own-account workers (40.6\%), followed by employees (38.7\%) and contributing family helpers (18.2\%). Among men, $52.2 \%$ were own-account workers and $41.2 \%$ were employees. Among women, $50.1 \%$ were contributing family helpers and $32.8 \%$ were employees.

The number of unpaid family female helpers grew steadily from 4.7 million in 2002-2003 to 8.4 million in 2013. On the contrary, the number of men working as unpaid family labor decreased from 3.4 million in $2002-2003$ to 2.1 million in $2013 .{ }^{19}$ Approximately $60 \%$ of the increase in women's paid work during the 2000s was concentrated in urban areas, of which half was in the manufacturing sector. Over 2 million women were estimated to be employed in the ready-made garments industry, which dominates Bangladesh

\footnotetext{
${ }_{18}$ Footnote 15 (Labour Force Survey 2013), p. 66.

${ }^{19}$ Footnote 15 (Labour Force Survey 2013). p. 57.
} 
Table 3: Labor Force Participation Rates according to Selected Individual Characteristics, 1999, 2005, and 2010

\begin{tabular}{|c|c|c|c|c|c|c|}
\hline & \multicolumn{2}{|c|}{1999} & \multicolumn{2}{|c|}{2005} & \multicolumn{2}{|c|}{2010} \\
\hline & Male & Female & Male & Female & Male & Female \\
\hline Labor force participation rate & 0.84 & 0.24 & 0.86 & 0.30 & 0.83 & 0.36 \\
\hline \multicolumn{7}{|l|}{ Age } \\
\hline $15-24$ & 0.62 & 0.26 & 0.67 & 0.22 & 0.62 & 0.36 \\
\hline $25-34$ & 0.94 & 0.28 & 0.96 & 0.35 & 0.93 & 0.44 \\
\hline $35-44$ & 0.98 & 0.26 & 0.98 & 0.36 & 0.97 & 0.46 \\
\hline 45 and above & 0.84 & 0.18 & 0.86 & 0.27 & 0.83 & 0.18 \\
\hline \multicolumn{7}{|l|}{ Marital status } \\
\hline Unmarried & 0.63 & 0.29 & 0.67 & 0.19 & 0.61 & 0.28 \\
\hline Married & 0.93 & 0.24 & 0.94 & 0.31 & 0.91 & 0.38 \\
\hline Separated/widowed/divorced & 0.43 & 0.27 & 0.55 & 0.32 & 0.47 & 0.21 \\
\hline \multicolumn{7}{|l|}{ Highest class passed } \\
\hline No education & 0.90 & 0.26 & 0.93 & 0.33 & 0.90 & 0.32 \\
\hline Class i-v & 0.91 & 0.24 & 0.93 & 0.30 & 0.90 & 0.38 \\
\hline Class vi-viii & 0.79 & 0.21 & 0.88 & 0.26 & 0.86 & 0.42 \\
\hline Class ix-x & 0.79 & 0.21 & 0.76 & 0.21 & 0.69 & 0.37 \\
\hline SSC/equivalent & 0.68 & 0.23 & 0.68 & 0.22 & 0.67 & 0.34 \\
\hline HSC/equivalent & 0.68 & 0.23 & 0.67 & 0.26 & 0.50 & 0.25 \\
\hline Bachelor/equivalent & 0.77 & 0.33 & 0.82 & 0.43 & 1.00 & 1.00 \\
\hline Master equivalent & & & 0.88 & 0.51 & 0.81 & 0.48 \\
\hline Medical/engineering degree & & & 0.84 & 0.61 & 0.76 & 0.47 \\
\hline Technical/vocational education & & & 0.77 & 0.37 & 1.00 & 1.00 \\
\hline Others & & & 0.63 & 0.42 & 0.69 & 0.45 \\
\hline \multicolumn{7}{|l|}{ Literacy } \\
\hline Literate & 0.80 & 0.23 & 0.81 & 0.26 & 0.79 & 0.37 \\
\hline Nonliterate & 0.91 & 0.26 & 0.92 & 0.33 & 0.90 & 0.33 \\
\hline \multicolumn{7}{|c|}{ HSC = higher secondary certificate, $\mathrm{SSC}=$ secondary school certificate. } \\
\hline \multicolumn{7}{|c|}{$\begin{array}{l}\text { Source: S. Mahmud and S.H. Bidisha. 2016. Female Labor Market Participation in Bangladesh: Structural Changes and Determinants of } \\
\text { Labor Supply. In S. Raihan, ed. Structural Change and Dynamics of Labor Markets in Bangladesh: Studies on Labor and Employment. Dhaka: } \\
\text { SANEM Publications. }\end{array}$} \\
\hline
\end{tabular}

manufacturing export sector. There has also been significant recent growth in new areas such as public sector employment (teachers or health workers), selfemployment, and household enterprises. ${ }^{20}$ Women's participation in the ready-made garments sector, and the importance of this sector to national exports and economic growth, has contributed to changed

\footnotetext{
${ }^{20}$ K. Siddique. 2016. Report on Gender Aware Macroeconomic Analysis for Women's Economic Empowerment Program. Dhaka: United Nations Development Programme.
}

perceptions of women's economic and public role.

Visible change in women's roles in the economic sphere. According to the Global Gender Gap Report 2016, ownership of $12.70 \%$ of firms includes women; $4.80 \%$ of firms have women in the top management; and $25 \%$ of women (and $33 \%$ of men) have an account at a financial institution. ${ }^{21}$ The report also shows a .06 female-male

${ }^{21}$ World Economic Forum. 2015. Global Gender Gap Report 2015. Geneva. pp. 100-101. 
Table 4: Labor Force Participation Rates over Time

(\%)

\begin{tabular}{|c|c|c|c|c|}
\hline Item & $2002-2003$ & 2005-2006 & 2010 & 2013 \\
\hline Total & 57.3 & 58.5 & 59.3 & 57.1 \\
\hline Male & 87.4 & 86.8 & 82.5 & 81.7 \\
\hline Female & 26.1 & 29.2 & 36.0 & 33.5 \\
\hline \multicolumn{5}{|l|}{ Urban } \\
\hline Total & 56.8 & 55.7 & 57.3 & 56.7 \\
\hline Male & 85.1 & 83.2 & 80.2 & 81.7 \\
\hline Female & 27.4 & 27.4 & 34.5 & 32.9 \\
\hline \multicolumn{5}{|l|}{ Rural } \\
\hline Total & 57.5 & 59.4 & 60.0 & 57.3 \\
\hline Male & 88.1 & 88.0 & 83.3 & 81.6 \\
\hline Female & 25.6 & 29.8 & 36.4 & 33.7 \\
\hline
\end{tabular}

\section{Table 5: Employed Persons Aged 15 Years and over by Broad Economic Sector, 2013}

(\%)

\begin{tabular}{|l|c|c|c|}
\hline Sector & Total & Male & Female \\
\hline Total & 100.0 & 100.0 & 100.0 \\
\hline Agriculture & 45.1 & 41.7 & 53.5 \\
\hline Industry & 20.8 & 19.6 & 23.7 \\
\hline Services & 34.1 & 38.7 & 22.8 \\
\hline $\begin{array}{l}\text { Source: Government of Bangladesh, Bangladesh Bureau of Statistics. } 2013 . \\
\text { Labour Force Survey 2013. Dhaka. }\end{array}$ \\
\hline
\end{tabular}

Table 6: Persons Aged 15 Years and over by Status in Employment

\begin{tabular}{|l|r|r|r|}
\hline Status of Employment & Total & Male & Female \\
\hline Total & 100.0 & 100.0 & 100.0 \\
\hline Employer & 0.9 & 1.2 & 0.1 \\
\hline Own-account worker & 40.6 & 52.2 & 12.3 \\
\hline Contributing family helper & 18.2 & 5.1 & 50.1 \\
\hline Employee & 38.7 & 41.2 & 32.8 \\
\hline Others & 1.6 & 0.3 & 4.7 \\
\hline
\end{tabular}

Source: Government of Bangladesh, Bangladesh Bureau of Statistics. 2013. Labour Force Survey 2013. Dhaka.

ratio of legislators, senior officials, and managers (or $5 \%$ women and $95 \%$ men) and a .32 female-male ratio of professional and technical workers (or $24 \%$ women and $76 \%$ men). Though women continue to be a small minority in these positions, the report shows women slowly entering senior and decision-making posts that used to be mainly occupied by men.
Women's limited access to productive resources. Women continue to have more limited access than men to vital productive resources including land, housing, and technology. ${ }^{22}$ Women also have more limited access to information: in 2011, women accounted for only $15 \%$ of citizens reading newspapers and $28 \%$ of those using internet (though they were about half of those listening to radio and watching television). ${ }^{23}$ Women also have limited access to financial resources and services, and the constraints include lack of collateral (as ownership of property and land is limited by unequal inheritance rights) and insufficient financial literacy. ${ }^{24}$ The Government of Bangladesh has however taken initial measures to address this gap by giving priority to women entrepreneurs in the small and medium-sized enterprises (SMEs), as stated in the National Industrial Policy 2010: "Women Entrepreneurs will be given priority in the SME sector. At least 15\% of the total sanction will be held in reserve in favor of the women entrepreneurs and the interest rate will be $10 \%$ only." ${ }^{25}$ In line with this policy, the Bangladesh Bank has allocated $15 \%$ of refinance fund for women entrepreneurs and instructed banks and nonbank financial institutions to charge reduced interest rate of $10 \%$ (bank rate + $5 \%)$ to women entrepreneurs on refinance schemes. ${ }^{26}$

Increase of women in decision-making positions. Through elections to reserved seats and open seats, more women serve on local government councils, municipalities, and city corporations. This has increased opportunities for women to participate in decision-making and further legitimized a public role for women. In the cabinet formed in 2014, women led the following ministries: Ministry of Home Affairs,

${ }^{22}$ ADB. 2010. Country Gender Assessment: Bangladesh. Manila. p. 2.

${ }^{23}$ Government of Bangladesh, Bangladesh Bureau of Statistics. 2012. Population and Housing Census 2011: Socioeconomic and Demographic Report. National Series, Vol. 4. Dhaka.

${ }^{24}$ There are various measures taken by the Bangladesh Bank to remedy these constraints and facilitate women's entrepreneurship.

${ }^{25}$ Government of Bangladesh, Ministry of Industries. 2010. National Industrial Policy 2010. Dhaka. p. 22.

${ }^{26}$ Government of Bangladesh, Ministry of Finance. 2003. Chapter 8: Industrial Policy. http://www.mof. gov.bd/en/budget/15_16/ber/en/Ch-08.pdf 
Ministry of Agriculture, and Ministry of Women and Children Affairs (MOWCA). Women also led the Ministry of Primary and Mass Education and Ministry of Science and Technology. In the 10th Parliament, the 50 standing committees have 509 members, ${ }^{27}$ of whom 428 are males and 81 are females. ${ }^{28}$ The 2014 elections saw an increase in the number of women parliamentarians to 50 in the reserved seats and 19 directly electedbringing the percentage of women in the Parliament to $19.7 \% .^{29}$ Local government acts provide for direct elections of women to reserved seats. These acts are considered milestones because they have increased women's participation in politics and have provided a venue for women to develop their political skills. For instance, in the Union Parishad elections in 2011-2012, through these acts, 22 women were elected as chairs (compared with 4,132 male chairs), and 12,236 women were elected as members (compared with 38,036 male members). ${ }^{30}$ Though still few, women could use these acts as mechanisms to gradually increase their presence in the political sphere.

High rates of domestic violence. The recent survey on the prevalence of violence against women (VAW) carried out by the Bureau of Statistics (BBS) in 2011 shows the highest rates of violence against women found so far. This was the first nationally representative survey on VAW perpetrated by the current husband, previous husband, and non-partner perpetrators. As many as $87 \%$ of currently married women reported having experienced a type of violence in the last 12 months. Among the different types of violence reported, psychological violence was the most common, followed by physical violence. Regarding VAW by partners, the rate of sexual or physical violence is $67 \%$,

\footnotetext{
${ }^{27}$ The total is higher than the total of members of Parliament, as some are members of several committees.

28 Bangladesh Parliament. Name of Committees for 10th Parliament (Bangla). http://www.parliament. gov.bd/index.php/en/parliamentary-business/ committees/list-of-committees/name-ofcommittees-for-10th-parliament-bangla

${ }^{29}$ Election Commission Bangladesh. http://www. ec.org.bd/Bangla/

${ }^{30}$ Government of Bangladesh, Bangladesh Bureau of Statistics. 2012. Gender Statistics of Bangladesh 2012. Dhaka.
}

psychological violence $82 \%$, and economic violence 53\% (BBS 2012). Domestic violence is widely tolerated, even among women: one-third of women 15-49 years of age believe in at least one justification for a husband hitting his wife, such as arguing with him. ${ }^{31}$ The persistence of such attitudes suggests the deeply ingrained conservative gender norms and the importance of seizing all opportunities to promote respect for women's rights, dignity, and their contributions to households and communities.

Uneven burden of care work. Another area that highlights inequality between women and men is the uneven burden of care work, which is a constraint on participation in public life and in the workforce. This is often unpaid and performed by women, and generally is not recognized as valuable. The Centre for Policy Dialogue has recently assessed the household work of women to be $76.8 \%$ of GDP. ${ }^{32}$ There is increased policy attention to the distribution and amount of time spent by women and men on different economic and noneconomic activities. A recent BBS survey on time use found women spending far more time on care work compared with men (5.6 hours for women and only 1.5 hours for men), even when women are employed. On the other hand, men spend four times more than women in productive work (5.8 hours for men and 1.5 hours for women). ${ }^{33}$

Bangladesh performance in gender equality compared with other countries. The Global Gender Gap Report 2016 of the World Economic Forum presented Bangladesh as a top performing country in South Asia, recording a progress in the political empowerment gender gap. ${ }^{34}$ With a Global Gender Gap Index ${ }^{35}$ of .698, Bangladesh ranked 72 out of 144 countries

\footnotetext{
${ }^{31}$ Footnote 12 (Bangladesh Demographic and Health Survey 2011), p. 219.

32 F. Khatun, T. Khan, and S. Pervin. 2014. Estimating Women's Contribution to the Economy: The Case of Bangladesh. Dhaka: Center for Policy Dialogue.

${ }^{33}$ Government of Bangladesh, Bangladesh Bureau of Statistics. 2013. Time Use Pilot Survey 2012. Dhaka.

${ }^{34}$ World Economic Forum. 2016. The Global Gender Gap Report 2016. Geneva.

${ }^{35}$ A Global Gender Gap Index is a measurement of gender inequality in four dimensions: educational attainment, health and survival, economic participation, and political empowerment.
} 
in 2016. In 2006, the score was 0.627. During 2006-2016, with Global Gender Gap Index of .627 in 2006, the Global Gender Gap Index of Bangladesh improved by $0.07 .^{36}$ The World Economic Forum report attributed this increase to strong national commitment to better public health and education services, innovative poverty reduction programs, and strategic engagement in the world economy. ${ }^{37}$ Conversely, the Social Progress Index 2016 of the Social Progress Imperatives presented Bangladesh-with a Social Progress Index ${ }^{38}$ of 52.73, ranked 101 of 133 countries, and categorized as low social progress-the least performing country compared to four developing member countries of ADB in South Asia (Social Progress Index of Sri Lanka was 62.21, Nepal's was 57.40, and India's was 53.92. ${ }^{39}$

\section{Policy Environment for Progress Toward Gender Equality}

Bangladesh is a signatory to the Beijing Declaration and Platform for Action (1995), the Universal Declaration of Human Rights, and other international human rights instruments, particularly the Convention on the Elimination of All

${ }^{36}$ World Economic Forum. Global Gender Gap Index 2016. http://reports.weforum.org/global-gendergap-report-2016/rankings/ (accessed 11 December 2016).

37 On the education subindex, the country has a value of 0.94 (at medium level), which has evolved positively from 0.868 in 2006 . The subindex for economic activities was 0.477 in 2014 , which has not improved much since 2006. The health subindex was relatively high in 2006 at 0.950 and remained high in 2014 at 0.94 . The subindex for women's political empowerment increased from 0.267 in 2006 to 0.406 in 2014.

${ }^{38}$ Social Progress Index is a measurement of social progress in three dimensions: basic human needs, foundations of wellbeing, and opportunity. The basic human needs dimension includes nutrition and basic medical care, water and sanitation, shelter, and personal safety; the foundations of wellbeing dimension includes access to basic knowledge, access to information and communications, health and wellness, and environmental quality; and the opportunity dimension includes personal rights. Personal freedom and choice, tolerance and inclusion, and access to advanced education.

39 M. Porter, S. Stern, and M. Green. 2016. Social Progress Index 2016. Washington D.C.: Social Progress Imperative.
Forms of Discrimination against Women, the Convention on the Rights of the Child, the Declaration on the Elimination of Violence against Women, and the Declaration on the Right to Development. By doing so, Bangladesh has made itself an integral part of the ongoing global efforts to ensure gender equality.

Regarding national policies and laws, the Constitution ensures human and fundamental rights of citizens including women. Article 27 of the Constitution of Bangladesh states, "All citizens are equal before law and are entitled to equal protection of law." Article 28(1) states, "The State shall not discriminate against any citizen on grounds only of religion, race, caste, sex or place of birth." Article 28(2) states, "Women shall have equal rights with men in all spheres of the State and of public life." Article 28(4) states, "Nothing in this article shall prevent the State from making special provision in favour of women or children or for the advancement of any backward section of citizens."

There are provisions for reserved seats for women representatives. In the Parliament, through the 14th Amendment of the Constitution in 2004, the provision of women's seats was increased to 45 seats (in addition to the 300 general seats) and again to 50 through the 15th Amendment of the Constitution in 2011. The women are nominated in proportion to their seats by the parties present in Parliament, and are indirectly elected by the other members of Parliament. There are also provisions for direct elections to reserved seats for women (33\% of the total seats) in the different tiers of local government.

See Box 1 for the country's administrative structure and gender-related targets and quotas for representation of women in elected bodies.

The national planning documents, consecutive five-year plans, and poverty reduction strategy papers have integrated gender aspects in a progressive manner. Gender mainstreaming was adopted as an approach for all social and economic development sectors, starting from the Fourth Five Year Plan (1990-1995). The vision for gender equality as spelled out 


\section{Box 1: Administrative Structure and Gender-Related Targets and Quotas}

Bangladesh' administrative structure consists of divisions (8), districts (64), upazila or subdistricts (490), and unions with rural local government councils or parishads at district, upazila, and union levels (councils). There are 11 city corporations for the six largest cities (Dhaka, Chittagong, Khulna, Rajshahi, Sylhet, and Barisal) and pourashavas (urban municipalities) for 329 secondary towns. By some accounts, there are more than 500 places that should qualify as towns.

Government of Bangladesh's commitments to women's equitable representation in these include the following politically elected posts:

\section{Parliament}

- There are 300 general seats for members of Parliament with an additional 50 reserved seats for women appointed by political parties elected to Parliament as per 15th Amendment of the Constitution (2011).

- Since 2009 , the female share in the cabinet of ministers was $13 \%$; before that, the share was $3 \%-8 \%$ in various governments.

\section{Rural local government}

- District council elections took place in December 2016.

- Upazila parishads (second lowest tier of regional administration in Bangladesh composed of elected representatives) is headed by a chairperson; two elected vice-chairs, of which one must be a woman; and the chairs of all union parishads under the upazila. The female vice-chair leads half of the standing committees of the upazila parishad.

- Union parishads (third lowest tier of regional administration in Bangladesh composed of elected representatives) is composed of nine general members representing nine wards (one each, Union parishads having nine wards) and three reserved seats for directly elected female members, each covering three wards. Women are to chair one-third of standing committees.

\section{Urban local government}

- In city corporations and pourashavas, there are direct elections of women to reserved seats, with one seat for every three wards (with the number of wards varying with the size of the municipality).

- Local Government (Municipality) Law (2009) calls for greater participation of citizens in decision-making processes through town-level and ward-level citizen coordinating committees, and specifies that women should be $40 \%$ of the membership at the ward level.

- The law also specifies that women should hold two of the five seats of each municipal standing committee. These requirements and the provision for reserved seats for women reflect the overall government policy of increasing the participation of women in local decision-making.

\section{Administrative positions}

For administrative positions in government ministries and departments, there are recruitment quotas of $15 \%$ women in non-gazetted posts and 10\% women in gazetted posts. In 2013, the female share of public or government employment was $22 \%$, varying by class of officer-only $16 \%$ among Class I officers, and was even smaller for the top civil servants (4\%-6\% among secretaries and additional secretaries).

Note: Government employees in Bangladesh belong to four categories: Class I officers, Class II officers, Class III employees, and Class IV employees. Officers are also classified as "gazetted" officers and "non-gazetted" officers. Officers whose appointment, posting, transfer, and promotion are notified in the government gazette are known as gazetted officers. All Class I officers and some of the Class II officers are treated as gazetted officers.

Source: Government of Bangladesh, Bangladesh Bureau of Statistics. 2014. Statistical Pocketbook of Bangladesh 2013. Dhaka.

in the Seventh Five Year Plan (2016-2020) is that of establishing a country where men and women have equal opportunities and rights, and women are recognized as equal contributors in economic, social, and political development. The mission is to ensure women's advancement as self-reliant human beings, and to reduce discriminatory barriers by taking both developmental and institutional measures. The framework for women's empowerment and gender equality comprises four areas of strategic objectives: (i) improve women's human capabilities, (ii) increase women's economic gains, (iii) enhance women's voice and agency, and (iv) create an enabling environment for wome's advancement. ${ }^{40}$

\footnotetext{
${ }^{40}$ Government of Bangladesh, Planning Commission. 2015. Seventh Five Year Plan FY2016-FY2020. Dhaka.
} 
The National Policy for Women's Development has various positive measures. It was first formulated and approved in 1997, and revived in 2011 with a few amendments. It provides for equal wage for work of equal value for women and men, increased participation of women in the labor market, equal opportunity at the workplace, security, and removal of disparities in employment. It emphasizes political empowerment and women's participation in decisionmaking processes. To achieve the latter, it provides for $33 \%$ women's representation within political parties, and recommends that political parties nominate more women in the elections. Furthermore, to increase women's representation in the Parliament, the policy supports increasing the number of women's seats to $33 \%$ and advocates for direct elections of women to these extended number of seats. This is particularly significant as presently the total number of women members of Parliament is only 69 out of the total 350 members of the Parliament, 69 or $19.7 \%$ are women.

Following the approval of the National Policy for Women's Development was the approval of the National Action Plan (NAP) for Women's Advancement in 1998. In 2012, another action plan was approved, encompassing all the different aspects of women's life and all sectors. There is a plethora of policies and strategies including references to gender, and many of them have positive provisions for the practical needs and strategic interests of women.

Women's labor rights are protected by law. Through the revision of the Labour Act, 2006 in 2013 and formulation of Labour Rules in 2015, the rights of workers were addressed and initiatives taken to ensure a decent work environment. This included workers' right to trade unions, introduction of an insurance scheme, setting up of a central fund to improve the workers' living standards, and requiring 5\% of annual profit to be deposited in employee welfare funds. However, Bangladeshi law still is not compliant with some International Labour Organization (ILO) standards, including Convention No. 87 on Freedom of Association and Convention No. 98 on the Right to Organize and Bargain Collectively.
Although these abovementioned rights are not for women only, these provisions are of great importance to them because of the large number of women in industrial labor. The recent Labour Rules have also introduced detailed provisions such as on childcare and compensations. The National Industrial Health and Safety Council has drafted the Occupational Safety and Health Policy, which remains at the final stages of approval.

Women's migration is partially promoted. A ban on women's migration was withdrawn in 2003, resulting in a dramatic increase in the number of women migrating to different countries, including the Middle East. The government revised the Expatriates Welfare and Overseas Employment Policy 2016 that facilitates overseas employment and ensures decent work for all migrant workers. It recognizes women as a distinct group, and has a section on women migrants. To encourage women's participation in labor migration and to diversify their employment opportunities, gender-responsive activities are to be undertaken. The policy emphasizes regulation of recruiting agencies, clear information to migrants and employees, involvement of embassies at receiving end, specific contracts between recruiting agency at both ends, and training and orientation of migrant workers. The policy also provides for increasing women's participation as migrant workers through training and skills enhancement. Capacity development through enhancing financial knowledge, understanding of banking facility, knowledge of using remittance of expatriate workers, and provision of information related to employment especially for women have also been emphasized. Security training for the protection of migrant laborers has been incorporated. The need for diversification of women's employment opportunities has been recognized. In addition, there is the South Asian Association for Regional Cooperation Convention on Preventing and Combating Trafficking in Women and Children for Prostitution (2002) and the Child Labour Elimination Policy (2010). 


\section{Institutional Structures to Promote Action on Gender Equality Issues}

Various national development plans have emphasized the importance of gender mainstreaming in institutions, policies, and structures. Since women's empowerment is a cross-cutting issue, it is not only the Ministry of Women and Children Affairs (MOWCA) that is responsible for women's empowerment. It is crucial that all government sectors are equally involved in the integration of gender concerns, needs, and interests into their policies, plans, and programs. The MOWCA, as part of the National Women's Machinery, is mandated by the government to act as the focal point and catalyst for action on issues of women's equality and development. It also promotes a broader and more consistent response by all government agencies to the needs and priorities of women.

The following institutional structures are in place to ensure implementation and monitoring of the NAP:

- National Council for Women and Children Development (NCWCD)

- Parliamentary Standing Committee on Women and Children Affairs

- Women's Development Implementation and Evaluation Committee

- Interministerial Coordination Committee on the National Programs for the Prevention of Violence and Dowry

- MOWCA and its implementing agencies: Department of Women Affairs and Jatiya Mahila Sangstha (National Women's Association)

- Women in Development (WID) Focal Points Mechanism

- Policy Leadership Advocacy Unit in MOWCA

- District and Thana (subdistrict) level WID Coordination Committees.

National Council for Women and Children Development. The NCWCD is the most high-powered committee for women's development, headed by the Prime Minister. The council consists of 14 ministers, secretaries of 13 ministries, a member of the Planning Commission,
5 members of Parliament, and 10 prominent women, nominated by the government. The secretary of the MOWCA is the member secretary of NCWCD. Since it is chaired by the Prime Minister, it does not meet very often. It deals with women's empowerment as well as welfare and improvements in women's condition.

Parliamentary Standing Committee on Women and Children Affairs. The Parliamentary Standing Committee on Women and Children Affairs, headed by a member of Parliament, was established to fulfill the commitments of the National Women Development Policy. It has 10 members who meet monthly to review the activities of the MOWCA on behalf of the Parliament. The secretary of the MOWCA is the member secretary of this committee.

Women's Development Implementation and Evaluation Committee. The committee, headed by the minister of the MOWCA, was formed to monitor implementation of the NAP by different sectors. It is supposed to meet on a quarterly basis. The secretary of the MOWCA is the member secretary.

Interministerial Coordination Committee for the National Programs for the Prevention of Violence and Dowry. The committee includes representatives from the ministries and civil society. Its objective is to coordinate and review programs of all organizations and committees working on VAW. It reviews the activities of law enforcement agencies and meets twice a year.

Department of Women Affairs. The Department of Women's Affairs is under the Ministry of Women and Children Affairs and their main goal is to empower women and children and ensure their development in all spheres of life. Within the framework of the Sustainable Development Goals and the Poverty Reduction Strategy paper of Bangladesh, the department undertakes various development activities and implements them at the ground level. The key areas of their work include human resource development and selfemployment, poverty reduction and creation of employment opportunities, prevention of violence against women and children, 
institutional development and access to service delivery, and awareness raising and promoting gender equality.

Jatiya Mahila Sangstha. The National Women's Association is a statutory organization under MOWCA formed by the Jatiya Mahila Sangstha Act, 1991. It works with women's organizations registered with the Department of Women Affairs to promote the implementation of national and international commitments that are part of its mandate. It seeks to increase awareness of women's rights and development, increase their skills, provide resources for socioeconomic development, develop skilled workforce, and attain sociopolitical rights.

Women in Development Focal Points Mechanism. Since the Fourth Five Year Plan, all sectors and ministries are responsible for incorporating WID issues into their programs. Each ministry selects an official at the rank of joint secretary to function as the WID focal point. This mechanism was established in 1990 to ensure that gender concerns are included in the policies, plans, and programs of all line ministries. In 1997, the focal point position was upgraded to that of joint secretary or joint chief, and deputy secretary or deputy chief were nominated as associate WID focal points.

Policy Leadership Advocacy Unit. The unit plays an analytical role by reviewing sectoral policies to ensure consistency with the Convention on the Elimination of All Forms of Discrimination against Women and the National Women Development Policy. It also reviews national laws and policies to ensure consistency with international commitments and to prepare proposals for necessary changes to national laws. It is supposed to consolidate reports provided by WID Focal Points and to prepare reports for various interministerial committees. However, this unit is understaffed and under-resourced.

District and Subdistrict level WID Coordination Committees. The WID focal points at the district and subdistrict levels form a coordination committtee that facilitates and ensures gender mainstreaming in planning, design, reporting, and monitoring of development interventions at the field level.
The government recognizes the role of women's organizations and nongovernment organizations in national development efforts and encourages their participation in different forums and committees. The influence of such organizations is also internationally recognized, and a recent publication states, "There is a small but extremely active women's movement, largely urban based but with networks in the countryside, that has been extremely influential in protesting violenceagainstwomen and demandingfairer legislation.”41 Representatives of women's organizations and eminent women's rights activists, writers, and researchers are part of the National Women's Machinery that has been set up to monitor Beijing to monitor the fulfillment of the country's commitment to the Beijing Platform for Action. NGOs, women's organizations, and human rights organizations continue to play an active and important role. Their programs range from providing direct services to raising awareness, mobilizing support, community organizing, and policy advocacy. NGOs range from small village clubs to large NGOs, like the Building Resources Across Communities (BRAC). The various categories of civil society organizations are regulated by various government registration authorities such as the Ministry of Social Welfare, Department of Women Affairs, and their own boards.

In 2003, the Ministry of Finance took the initiative of establishing a monitoring and reporting facility called the Recurrent, Capital, Gender, and Poverty model, through which all expenditure items are disaggregated to indicate what percentage of allocated funds contribute to poverty reduction and gender equity. The system allows government ministries to enter estimates in terms of percentages for recurrent, capital, gender, and poverty information. It provides a yearly trend analysis by ministry for recurrent, capital, gender, and poverty expenditures. The data is provided when the ministries fill in the required formats while responding to Budget Call Circular 1. The Ministry of Finance has been driving the gender responsive

\footnotetext{
${ }^{41}$ N. Kabeer et al. 2013. Paid Work, Women's Empowerment and Inclusive Growth: Transforming the Structures of Constraint. UN Women. p. 63.
} 
budgeting agenda as part of the midterm budgeting framework process, which began in fiscal year (FY) 2006 with four ministries and now covers all the ministries. It requires all ministries to explicitly relate their budget proposals to the policy priorities of the government and the ministries' mandates.

\section{General Contents and Organization of this Gender Equality Diagnostic}

With the general country context, status of women, supporting policy environment and institutional structures for gender equality as backdrop, this gender equality diagnostic examines in-depth the gender dimension of four selected priority sectors (i.e., urban development, energy, transport, and tertiary and vocational skills development) of ADB in the country. The next four chapters correspond to these four selected sectors.
The gender dimension of each sector is tackled in seven parts: (i) summary of gender issues, actions undertaken, and prospects for strengthened pursuit of gender equality in and through the sector; (ii) sector context for the pursuit of gender equality; (iii) key gender issues in the sector; (iv) sector policies and institutional context for addressing gender inequality; (v) good practices and lessons in mainstreaming gender equity in the sector; (vi) ADB experience in mainstreaming gender equity in the sector; and (vii) ways to strengthen gender equality approaches in the sector. Each sector chapter ends with two annexes. The first annex contains a tip sheet on the analysis of gender issues and selection of approaches for gender mainstreaming in programs and projects in the sector; and the second annex is a list of useful resources for further reading. Unless otherwise specified, data refer to available data as of December 2016. 


\section{Urban Sector}

\section{Summary}

Bangladesh is undergoing rapid urbanization, which contributes to economic growth, creation of jobs and livelihoods, as well as growth of low-income settlements and slums. Women and the poor face multiple insecurities and challenges in the urban environment, including finding and keeping housing, securing tenure, and accessing basic facilities such as water, electricity, and services (e.g., education and health). Slums are more underserved than the rural areas. Women and girls are more exposed to violence and threats of violence in public spaces, at the workplace, and at home. The institutional and policy context makes it difficult to address the specificities of urban life. There are multiple agencies that function independently and despite local government bodies working together, there is further scope for improving their effective coordination. While the draft urban policy is yet to be approved, the government is working on reforming the government structures and institutions dealing with rapid urbanization. There are positive policy directions in the Seventh Five Year Plan, and sectoral policies such as water supply and sanitation (WSS) and health address urban development. Urban local government legislation has been revised from time to time, and city corporations and municipalities are being given greater authority and responsibilities. Although transport is often considered as an urban issue, this report will deal with both urban and rural transportation separately in the next chapter.

With increasing attention given to urban development, there are several good practices which have been developed by the government and others to address priorities and participation of women and girls. These include institutional measures such as adopting gender policies and setting up a Gender and Development Forum in the Local Government Engineering Department (LGED), providing low-cost housing for the urban poor through loans, initiatives to increase women's safety and security in public spaces, and childcare in the slums for working mothers. ADB and government agencies working in the urban sector have also evolved several good practices. Institutional capacity has been developed through gender action plans (GAPs), employment of gender specialists; identification and allocation of resources to gender-specific project objectives, outputs, and activities; and active monitoring and follow-up. Elected women representatives of the urban local government have been involved in project activities, and their capacity and role in local planning and budgeting have been enhanced. Investments have been made to make public space more women-friendly, and women's employment at all levels has been promoted with stress on maintaining labor standards and equal wages for work of equal value. Various challenges remain due to the scale of urbanization, and new challenges have emerged with changes in the context. Several follow-up actions are identified to strengthen gender equity approaches in urban development in planning and policy making, institutional capacity development, strengthening women's leadership, resource allocation, monitoring, and public-private partnerships. Annex 1 provides a tip sheet on questions and design features for gender mainstreaming in urban development projects, and Annex 2 provides a list of resources for further reading.

\section{Sector Context}

Urbanization is rapidly growing. Of the total population of 148 million, $28 \%$ or 46 million live in urban areas. They are largely concentrated in the four largest 
cities of Dhaka, Chittagong, Khulna, and Rajshahi. Greater Dhaka is one of the fastest growing cities in the world. Each year about 300,000 to 400,000 new migrants arrive. By 2025, it will have a population of 22 million, making it the eighth largest city in the world..$^{42}$ The growth of the urban areas is due to natural population growth, territorial expansion of urban areas, and rural to urban migration, where women are more involved than was the case in the past. According to the agglomeration index, an alternative measure of urban concentration, the share of Bangladesh's population living in areas with urban characteristics in 2010 was $45.7 \%$. This compares with an urban share of the population based on official definitions of urban areas of almost $28 \%$, suggesting the existence of considerable hidden urbanization. ${ }^{43}$

Urbanization is known to be an effective engine of economic growth and sociocultural development. In economic terms, despite only $28 \%$ urbanization, urban areas contribute to more than $60 \%$ of the GDP, which grew from $25 \%$ in $1972-1973$ to $45 \%$ in $1995-1996 .{ }^{44}$ However, the rapid urbanization that Bangladesh is experiencing also has many negative consequences and challenges such as poor access to transport, sanitation, housing, health, and education services, as well as congestion and pollution. Inhabitants of slum settlements are particularly affected by these problems. To cope with the growth rate, realistic urban planning is necessary to ensure access to utility services, health, energy, education, livelihoods, and transportation for social, environmental, and economic development.

Women's vulnerabilities are a reason for concern. The Beijing +20 national report has identified urbanization as a key priority for action for women in the

\footnotetext{
${ }^{42}$ M. Hildebrand et al. 2012. Sustainable Urbanization and Poverty Reduction Asia Pacific. Draft UNDP Urban Strategy. Bangkok: UNDP.

43 World Bank. 2015. Leveraging Urbanization in Bangladesh. World Bank Brief. 24 September. http://www.worldbank.org/en/country/ bangladesh/brief/leveraging-urbanizationbangladesh

${ }^{44}$ N. Islam. 2013. Overview of Urbanization in Bangladesh. A presentation to the Urban Dialogue organized by Habitat for Humanity. Dhaka. 1 September.
}

next 3-5 years. It states that unless rapid urbanization is managed strategically, it can cause reversals in the progress that has been made for women's empowerment. Women are particularly affected in lowcost settlements in accessing water, gas, electricity, sanitation, and transportation. They are also subject to frequent sexual harassment and violence that are specific to urban settlements having dense and flimsy housing, communal toilets and water points, and insufficient lighting. ${ }^{45}$

Women and families are a significant portion of the slum population. The proportion of the poor living in the urban areas increased from $10 \%$ in 1992 to $18 \%$ in 2010, and the number of poor living in urban areas increased from 6.2 million in 1992 to 8.3 million in 2010 . The pattern in the future is likely to be that, although overall poverty rates will decline, an increasing share of the remaining poor will live in towns as the towns grow. ${ }^{46}$ According to the Census of Slum Areas and Floating Population conducted in 2014 by BBS, a total of 13,938 slums and 2.2 million people covered all city corporations, municipalities, upazila headquarters, and all other urban areas. Of this population, 1,139,768 were male and 1,086,180 were female, and 1,806 were hijra (transgender) giving a male to female sex ratio of 105 . The sex ratio is significant because, formerly, rural to urban migration was mainly male, but now women as well as entire families are migrating to urban areas. A total of 592,998 slum households of an average size of 3.75 persons were counted in 2014. This is an increase of $77 \%$ in the number of slum households over the 17 years since the 1997 census was released (against an increase of $36 \%$ in the number of slums over the same period). ${ }^{47}$ The government MDGs report of 2015 stated that $5.25 \%$ of the total urban population lived in the slum areas in

\footnotetext{
${ }^{45}$ Government of Bangladesh, Ministry of Women and Children Affairs. 2014. Bangladesh Report: The Implementation of the Beijing Declaration and Platform for Action (1995) and the Outcomes of the Twenty-Third Special Session of the General Assembly (2000). Dhaka.

${ }^{46}$ World Bank. 2012. Bangladesh: Towards Accelerated, Inclusive and Sustainable Growth-Opportunities and Challenges. Washington, DC.

47 Government of Bangladesh, Bangladesh Bureau of Statistics. 2014. Census of Slum Areas and Floating. Population. p. 26.
} 
Table 7: Urban, Rural, and Slum Values for Selected Indicators of the 2009 Multiple Indicator Cluster Survey

\begin{tabular}{|l|c|c|c|c|}
\hline & & & & Slum worse than rural \\
Indicator & Urban & Rural & Slum & 44 \\
\hline Under-five mortality rate (per 1,000 live births) & 53 & 66 & 95 & -21 \\
\hline Skilled attendant at birth & $45 \%$ & $19 \%$ & $15 \%$ & -83 \\
\hline Population using an improved sanitation facility & $54 \%$ & $54 \%$ & $9 \%$ & -41 \\
\hline Net attendance ratio in pre-school education & $26 \%$ & $22 \%$ & $13 \%$ & -20 \\
\hline Net attendance ratio in primary education & $84 \%$ & $81 \%$ & $65 \%$ & -40 \\
\hline Pupils starting Grade 1 who reach Grade 5 & $80 \%$ & $80 \%$ & $48 \%$ & 700 \\
\hline Drop out in primary education & $1 \%$ & $1 \%$ & $8 \%$ & -63 \\
\hline Net attendance ratio in secondary education & $53 \%$ & $48 \%$ & $18 \%$ & -27 \\
\hline Youth literacy (women aged 15-24 years) & $77 \%$ & $70 \%$ & $51 \%$ & -27 \\
\hline Adult literacy (women aged 15-49 years) & $66 \%$ & $48 \%$ & $35 \%$ & 7 \\
\hline Gender parity index in secondary education & 1.08 & 1.18 & 1.26 & -48 \\
\hline Birth registration & $53 \%$ & $54 \%$ & $28 \%$ & \\
\hline $\begin{array}{l}\text { Source: Westhof, Dirk. 2010. Understanding Urban Inequalities in Bangladesh: A Prerequisite for Achieving Vision 2012. Dhaka: United } \\
\text { Nations Children's Fund. p. 13. }\end{array}$ & & & \\
\hline
\end{tabular}

2014 in Bangladesh. ${ }^{48}$ Dhaka has one of the biggest slum populations and the highest proportion of slum dwellers.

Slum dwellers face multiple insecurities. Depending on the types of slums ${ }^{49}$ and the cities, between a third and half of the slum population are tenants or squatters who suffer from insecurity of tenure and, more often, not all of them benefit from development interventions. Land values in parts of Dhaka exceed those in Manhattan, making evictions a constant threat for those living in informal settlements, especially on private land..$^{50}$ The poor pay as much and sometimes more per square foot than people living in better quality housing.

${ }^{48}$ Government of Bangladesh, Planning Commission. 2015. Millennium Development Goals Report 2015. p. 102.

${ }^{49}$ In the Multiple Indicator Cluster Survey (UNICEF/BBS), urban areas are broken down into municipality, city corporation, and slums. Slums are defined as settlements with a minimum of 10 households or a mess unit with a minimum of 25 members and predominantly very poor housing; very high population density and room crowding; very poor environmental services, especially water and sanitation; very low socioeconomic status; and lack of security of tenure. Source: Islam, N., A.Q.M. Mahbub, and N. Nazem. 2009. Urban slums of Bangladesh. The Daily Star. 20 June. http://www .thedailystar.net/story.php?nid=93293

${ }^{50}$ M. Sattar. 2014. Why the cost of real estate in the crowded, slum-packed city of Dhaka rivals Manhattan. Global Post. 9 April.
Utilities are more expensive, and the urban poor often pay more for water that is not as clean and electricity that is less reliable. ${ }^{51}$ Health problems are particularly serious in slums. Although health is improving nationally, the rates of noncommunicable diseases in slums are rising, a rise caused largely by the poor living environment and diet. Only $27 \%$ of slum dwellers consult qualified doctors (compared with $71 \%$ of other urban dwellers). Health programs reach only half of all slum dwellers. About $79 \%$ of households have to manage their own solid waste collection, $25 \%$ have no sanitation, and $22 \%$ have an inadequate supply of drinking water. ${ }^{52}$ These conditions affect women and children more than men.

Table 7 shows that slums have the worst values for 12 indicators of the 2009 Multiple Indicator Cluster Survey.

Low-cost housing is scarce. Bangladesh's expanding urban populations presents it with a considerable affordable housing challenge. In the best-case scenario

\footnotetext{
51 The average rent in slums is Tk41 per square foot. A middle class flat in Mohammadpur costs Tk13 per square foot. See Shaon, A.I. 2014. Slum dwellers pay more but get much less. Dhaka Tribune. 10 February.

52 D. Westhof. 2010. Understanding Urban Inequalities in Bangladesh. A Prerequisite for Achieving Vision 2012. Dhaka: UNICEF
} 
in which urban population density remains constant, meeting this challenge will require expanding the amount of developable urban land by just over 7,000 square kilometers $\left(\mathrm{km}^{2}\right)$, or almost $45 \%$, between 2010 and $2050 .{ }^{53}$

The Sustainable Development Goals have gone further than the Millennium Development Goals in addressing urban development. This is true with Goal 6 (Ensure availability and sustainable management of water and sanitation for all) and Goal 11 (Make cities and human settlements inclusive, safe, resilient and sustainable). Target 11.1 addresses access to safe and affordable housing; target 11.2 safe, affordable, accessible, and sustainable transport systems; target 11.3 inclusive and sustainable urbanization and capacity for participatory planning; target 11.6 reducing the adverse environmental impact of cities; and target 11.7 universal access to safe, inclusive, and accessible green and public spaces, particularly for women and children, older persons, and persons with disabilities. As these are issues that have been identified in the gender analysis of urban development as important, the provisions in the Sustainable Development Goals (SDGs) will help focus attention and resources on them in Bangladesh in the coming years.

\section{Key Gender Issues in the Sector}

Urban issues affect women differently. Urban development includes water supply, waste management, drainage, transportation, electrification, housing, land use planning, slum improvement, sanitation and hygiene, environmental management, and employment generation. Women and men differ in their roles, needs, and perceptions regarding urban development. Women are often the primary collectors, transporters, users, and managers of domestic water and promoters of home and community-based sanitation activities. Women also play a primary role in waste disposal and environmental management. They also bear a primary responsibility in household chores and

\footnotetext{
${ }^{53}$ Footnote 43 (Leveraging Urbanization in Bangladesh).
}

childcare, hence housing design including lighting, ventilation, and security is of immediate importance for them. Access to services and transportation has specific implications for women and men, young and old, and for those differently abled. Poorer settlements such as urban slums are also likely to include populations living in households headed by women, and such households also have special needs. Gender norms often constrain women's mobility and access to services, education, and employment opportunities. Violence, or the threat of violence, is one of the constraining factors. Other constraints are lack of knowledge, poor confidence, and inadequate economic resources.

Women are more affected by time poverty. As income poverty in urban areas is compounded by inadequate and expensive accommodation, limited access to basic infrastructure and services, exposure to environmental hazards, this puts a "disproportionate burden on those members of communities and households who are responsible for unpaid care work such as cleaning, cooking and looking after children, the sick and the elderly." ${ }^{44}$ Also, because of cash poverty, women and girls are compelled to work in either informal or formal low-paid activities. Their access to work is constrained by their unequal position in the urban labor market and their limited ability to secure assets independently of male relatives. At times of increasing prices and economic crises, women have to work longer hours for the same income or to be able to manage within the same income. ${ }^{55}$ This results in women having to work increasingly long hours combining both paid and unpaid care work, which leads to time poverty. BBS statistics show that in the urban areas women are spending 3 hours on household work compared with 1 hour for men (3.6 hours for women in rural areas). However, women in urban areas are spending more time in

\footnotetext{
${ }^{54}$ C. Tacoli. 2012. Urbanization, Gender, and Urban Poverty: Paid Work and Unpaid Care Work in the City. Urbanization and Emerging Population Issues Working Paper. No. 7. London: International Institute for Environment and Development and United Nations Development Programme. p. 4.

55 N. Hossain. 2009. Reading Political Responses to Food, Fuel and Financial Crises: The Return of the Moral Economy? Development. 52 (3). pp. 329-333.
} 
paid work (6.2 hours) than rural women (5 hours). ${ }^{56}$

Slum dwellers have greater difficulties in access to services. Data from the 2009 Multiple Indicator Cluster Survey in Bangladesh indicates that conditions in slum areas are much worse than those in most rural areas, even in regard to indicators such as secondary education attendance rate and skilled attendant at birth (Table 7). Literacy rates are lower in rural areas, though gender parity in secondary education is higher. Access to skilled birth attendants or even sanitation is lower than in rural areas. Slum populations are twice as likely as rural populations to have improved sanitation, but it is usually shared and of poor quality. In slums, $86 \%$ of households share a latrine and half of households share with five or more persons. Since often it is the women who have the primary responsibility for accessing services for the family (health or water), they are the ones who have to bear the brunt of the difficulties, such as having to stand in line for water, rations, or other services. This results in time poverty and raises economic costs. On the other hand, awareness on menstrual hygiene and management has gained importance as part of health and well-being of women and girls.

Women's disadvantages compared with men become clear when reproductive health issues are considered. This includes maternal health services along with contraception, reproductive health education, adolescents' ability to take decisions regarding their body, as well as bodily integrity and freedom from violence.

Waterlogging, poor drainage, and lack of safe water aggravate women's difficulties. Aggravated by climate change, environmental problems are multidimensional, cut across many sectors, and are particularly acute in urban areas. A combination of unsafe and insufficient water supply, sanitation, and storm drainage can greatly threaten urban environmental health, and infant and child mortality in particular, thus increasing

\footnotetext{
${ }^{56}$ Government of Bangladesh, Bangladesh Bureau of Statistics. 2013. Time Use Pilot Survey 2012. Dhaka. p. 26.
}

women's household responsibilities as well as damaging their reproductive and general health and well-being. In Bangladesh, which is situated on the flood plains of Ganges and Brahmaputra, flooding is natural. Urbanization and the building of roads and embankments have in many cases interfered with the natural drainage. While flood embankments have been built to protect urban areas from flooding, they also do not allow water to flow out. They have also led people to build their houses in low lying areas, making them prone to flooding and waterlogging during certain periods of the year.

Women are negatively affected by housing or tenure insecurity. There is a significant shortage in housing stock. Majority of the dwelling units are structurally very poor, lack services and utilities, and are built without proper planning. As for the tenure conditions, about $40 \%$ of the urban dwellers live in an informal status. ${ }^{57}$ Secure shelter that is affordable and protected from arbitrary eviction is critical for both women and men. However, women are less likely to be legal owners or occupiers of their homes, as men are typically assumed to be heads of households and therefore land and housing titles tend to be registered in their names. Divorced or deserted women may face eviction or homelessness, and widows may lose their rights to the family home. Legal, financial, and social restrictions limit women from owning land or their homes; women are more likely to be renters. Renting generally provides less security than owning homes or land.

Housing finance for the poor is limited. Despite the opportunities that exist for the poor to access collateral-free credit, NGOs and microfinance institutions are unable to offer housing finance options to the poor because of land tenure or insecurity issues and because the poor do not have land titles. The Seventh Five Year Plan has emphasized the importance of creating an efficient housing market and improving mechanisms for housing financing under the proposed urban strategy. In June 2016, the World Bank approved the $\$ 50$ million

\footnotetext{
${ }^{57}$ N. Islam and S. Shafi. 2008. A Proposal for a Housing Development Program in Dhaka City. Dhaka: Centre for Urban Studies. p. 20.
} 
Low Income Community Housing Support Project that will pilot a community-driven approach to improve the living conditions of the urban poor in selected municipalities. The focus of the project is on secondary towns and/or city corporations outside Dhaka. The United Nations Development Programme is working on the upcoming Community Housing Development Fund, which will focus on community-based access to housing finance for municipalities and city corporations outside Dhaka.

The formal and informal sectors are faced with problems. The formal sector has been struggling to respond to the need for employment of men and women, and the informal sector has seen a growth (in manufacturing, trade, and services) with both its advantages and disadvantages. ${ }^{58}$ Poor urban women tend to concentrate on lower-quality and insecure forms of paid work to be able to carry out their family responsibilities for unpaid domestic work and care work. Another reason is that the gender segregation of labor markets prevents women from entering better paid and protected work. Domestic work is likely to be a major category of employment for women in urban areas of low and middle-income countries. This is related to the increased labor force participation of women in middle-income households who then need support for household work and childcare. ${ }^{59}$ Workers in the informal sector are unprotected by law, face abuse and discrimination, do not get regular work, are paid low wages, and work long hours. ${ }^{60}$

Women's employment in the manufacturing sector increased from $13.3 \%$ in 2010 to $23.7 \%$ in 2013. In $2013,33 \%$ of all the workers in industry were women (compared with $22.5 \%$ in 2010). ${ }^{61}$ This increase is mainly in the urban areas. However, the jobs available, although better than in the informal sector, are often at the lower end in terms of skills and salaries.

\footnotetext{
58 See "Status of Women" under Overview.

59 Footnote 54 (Urbanization, Gender and Urban Poverty), p. 18.

60 Rights of domestic and agricultural workers are not included in the present Labour Law of 2013.

61 There are also changes in the definition of the industry that explain part of this increase.
}

Insecurity or violence against women in urban areas is a major concern. While Bangladesh has high prevalence of violence against women (VAW) in general, the urban context has certain specificities (Box 2). Violence takes place in the home, workplace, and public spaces. There are a few differences between urban and rural areas in that more urban women frequent work places (32.09\% versus $27.70 \%)$, solitary or public spaces $(45.03 \%$ versus $42.88 \%$ ), and educational institutions as sites of possible sexual violence (15.99\% versus 11.08). ${ }^{62}$ Also, in urban areas, women tend to work outside the home even after dusk (unlike in rural areas), and women and girls face higher chances of violence in the streets and public spaces. See Box 2 for a discussion of VAW in urban contexts.

\section{Box 2: Prevalence of Violence against Women in Urban Contexts}

There is evidence of higher prevalence of violence against women (VAW) in urban areas, including slums. About $66 \%$ of women in slum areas reported experiencing physical and/or sexual violence, and $45 \%$ in non-slum areas. ${ }^{a}$ A study by International Centre for Diarrhoeal Disease Research, Bangladesh (icddr,b) carried out in 2011 found that about $52 \%$ of urban men and $46 \%$ of rural men reported emotionally abusing their female intimate partners during their lifetime. Both this study and others show that there is widespread acceptance of VAW among men and women. Another study found that Bangladesh is also characterized by high levels of physical violence against unmarried female adolescents, which varies widely across communities. ${ }^{\mathrm{b}}$ Another study reported that $43 \%$ of rural unmarried adolescent girls experienced sexual harassment on their way to school, college, or social visits. ${ }^{c}$ In urban areas, girls have greater mobility for work compared with girls in rural areas. Widespread sexual harassment and intimidation on the way to work was reported by the young female garments workers in a qualitative study in Dhaka city. ${ }^{\mathrm{d}}$

a National Institute of Population Research and Training (NIPORT). 2011. Bangladesh Demographic and Health Survey 2009. Dhaka.

${ }^{\mathrm{b}}$ NIPORT; MEASURE Evaluation; icddr,b; and Associates for Community and Population Research, Bangladesh Urban Health Survey.

c icddr,b and Population Council. 2013. From Evidence to Policy: Addressing Gender-Based Violence against Women and Girls in Bangladesh. A report submitted to Department for International Development.

${ }^{d}$ N. Alam, S. Roy, and T. Ahmed. 2010. Sexually Harassing Behavior against Adolescent Girls in Rural Bangladesh: Implications for Achieving Millennium Development Goals. Journal of Interpersonal Violence. 25(3). pp. 443-456; D. Siddiqi. 2003. The Sexual Harassment of Industrial Workers: Strategies for Intervention in the Workplace and Beyond. CPD-UNFPA Working Paper Series. No. 26. Dhaka: Centre for Policy Dialogue and United Nations Population Fund.

\footnotetext{
${ }^{62}$ Government of Bangladesh, Bangladesh Bureau of Statistics. 2013. Report on Violence Against Women Survey 2011. Dhaka.
} 
Women's and men's voice and/or influence is constrained. While urban local bodies strive to adequately represent and respond to the needs of citizens, women and men, there is scope to further strengthen the urban local governance and management systems to meet their needs better. However, the urban poor are beginning to see local politicians not as sources of individual patronage and preferment, but as representatives of their collective needs and views and whose performance in addressing these will be assessed at the ballot box. In turn the politicians are beginning to see the urban poor not as people whose votes can be bought via mastaans (gangsters), but as constituents whose legitimate needs must be addressed. This has been given impetus by the election of female members to reserved seats as local councilors and their inclusion in various committees and project activities by development projects. ${ }^{63}$

\section{Policy and Institutional Context for Addressing Gender Inequality}

\section{- National Legislation and Policies in the Urban Sector, and Gender Features}

In general, the provisions of national legislations and policies in the urban sectors that enable greater citizens' participation and accountability to users are likely to bring benefits to women and girls. The Local Government Ordinance of 1976 and the Pourashava Ordinance of 1977 originally created the basis for management of towns by elected councils and chairpersons. The latter was replaced by the Local Government (Pourashava) Act of 2009, which increased the responsibilities of municipalities for town planning and development, public health and sanitation, water supply and sewage disposal, and maintenance of public infrastructure. Participation of certain sections of the citizenry in decision-making processes has improved.

\footnotetext{
${ }^{63}$ N. Hossain and S. Akhter. Draft. Gender, Power, and Politics in Bangladesh: A baseline study for the Upazila Support Project. Dhaka: UNDP/DFID and UGIIP II of LGED/ADB.
}

There is a need for a comprehensive urban policy. The government has long been aware of the rapid pace of urbanization and the associated physical, economic, and social problems, and a comprehensive urban policy has been drafted that, once approved, will streamline the various pieces of legislation that are currently in place. For example, flood management of relevance to urban areas can, to some extent, be considered covered by the 1988 Flood Action Plan, and later by the National Water Management Plan of 2000, which was approved in 2004. Recently, the government approved the Strategic Transport Plan for Dhaka (2008). A draft urban policy was first formulated in 2004, and the $2013 \mathrm{draft}$ addresses gender issues positively. One of the objectives is "to include all classes of local citizens, including women and poor people, in participatory decision-making and implementation processes." One of the priorities identified for the policy is "gender awareness and sensitivity." The draft policy deals with most of the priority interests of women living and working in urban slums including housing, security of tenure, housing finance, physical security, and access to services. The draft urban policy suggests the need for upgrading or improvement of slums that are listed and categorized as "tenable." It suggests that to ensure security of tenure, steps should be taken to grant land tenure to the poor on government or municipal lands considered tenable. The provision of tenure and settlement rights are also an important area to ensure that gender considerations are addressed and that the process and means recognize and protect women as well as men tenants as well as those claiming ownership. ${ }^{64}$

Water and sanitation policies address urban issues. The provision of water and sanitation benefited from policy development starting in 1998 with the approval of the National Policy for Safe Water and Sanitation, emphasizing the principles of user participation, decentralization of water supply and sanitation (WSS) management to local government institutions and community-

\footnotetext{
${ }^{64}$ Government of Bangladesh. Draft. National Urban Policy.
} 
based organizations, and involvement of NGOs and the private sector in WSS service delivery, thus addressing women's use and involvement. It supported a new role for the Water Supply and Sewerage Authority (WASA) in Dhaka and Chittagong to promote collective initiative in slums and among squatters in accessing water supply services for payment. Subsequently, the government approved the Sector Development Framework (2004), the National Sanitation Strategy (2005), and the Pro-Poor Strategy (2005). While the MDGs set the target of reducing by half the percentage of people without safe water and basic sanitation by 2015, the government set a more ambitious target in 2005 of $100 \%$ coverage by 2010 . Due to women's greater responsibility for family health and hygiene, these improvements in water and sanitation have benefited women by increasing their well-being and reducing their workloads.

The Seventh Five Year Plan recognizes rapid urbanization as an essential part of the underlying growth process. The plan strategy has increased the focus on issues that can directly benefit women and disadvantaged groups by improving urban governance through better transparency and accountability of institutions, decentralization, community participation, more efficient resource mobilization, and involvement of the private sector in the development of the urban sector. Provision of adequate and affordable basic urban infrastructure and services, which are essential for safeguarding health, safety, welfare, and improved living environment of the poor and women, is to be an important strategic focus under the plan. The gender strategy of the plan also emphasizes the importance of ensuring women benefit from urbanization and are protected from its risks.

\section{- Bangladesh Urban Sector Agencies, Organizations, and Their Activities}

There are 11 city corporations for the largest cities and urban municipalities (pourashavas) for 329 secondary towns. ${ }^{65}$ Locally generated revenues make up about $30 \%$ of the total revenue, but collection

\footnotetext{
${ }^{65}$ Footnote 40 (Seventh Five Year Plan), p. 524.
}

rates are low (only $30 \%-40 \%$ is collected) ${ }^{66}$ This has implications for the budgets urban local government bodies can allocate for social development and gender-related activities. However, there have been positive examples whereby municipal corporations have increased revenue collection and made their own allocations for social development and gender-related expenditures. ${ }^{67}$

The Ministry of Local Government, Rural Development, andCooperativeshasremained responsible for a large part of the main implementation and supervision of public sector WSS in the country, mainly through its departments: (i) Local Government Division, which carries out policy formulation and strategic planning for the sector and monitoring; (ii) Department of Public Health Engineering, which is responsible for providing WSS services in areas not served by water and sewerage authorities (Dhaka and Chittagong), and for provision of technical assistance (TA) to local bodies responsible for WSS; (iii) Local Government Engineering Department (LGED), which is responsible for rural infrastructure and assistance to municipalities, including WSS in some externally supported integrated development projects; (iv) local government institutions such as union parishads, upazila parishads, and pourashavas, which are responsible for managing communal WSS systems; and (v) the National Institute of Local Government, which is responsible for much of the capacity development of local bodies.

\footnotetext{
${ }^{66}$ W. Fox and B. Menon. 2008. Decentralization in Bangladesh: Change has been Illusive. International Studies Program Working Paper. No. 08-29. Atlanta, Georgia: Georgia State University. http://icepp.gsu.edu/files/2015/03/ ispwp0829.pdf; World Bank. 2013. Bangladesh: Municipal Governance and Services Project (Project Document, Project Appraisal Document). Washington, DC. These two sources contradict each other: Georgia State University cited 30\% as the ratio of own source to central government funding for urban local bodies, while the World Bank cited a ratio of $4 \%-6 \%$

${ }^{67}$ For example, with project facilitation, over the course of the Second Urban Governance and Infrastructure Improvement (Sector) Project (UGIIP-II) municipal corporations expended Tk141.5 million from own revenue for their gender action plan (GAP) implementation, outside of project funds (as of March 2015). ADB. 2015. Second Urban Governance and Infrastructure Improvement (Sector) Project. Manila (Project 40559-013- BAN)
} 
Each government ministry and department has a WID focal point situated in the planning cell to oversee integration of gender issues into planning, monitoring, and budget allocations. While the focal points work as effectively possible, given their multiple responsibilities, they do not always have enough time and resources to carry out their tasks properly. There is also scope to build their capacity further to perform as WID focal points effectively. LGED stands out for its investments in policies and structures that promote gender equality: it has a gender strategy and a functional gender forum. Dhaka WASA has a gender strategy. See Box 3 for information on the LGED Gender and Development Forum.

\section{Box 3: Institutionalizing Gender Mainstreaming in Local Government Engineering Department: Gender Equality Strategy and Forum}

The Local Government Engineering Department (LGED), in accordance with its gender equality strategy, ensures that all its infrastructures are made women-friendly, create employment opportunities for the women in different activities, and establish increasingly a process of decision-making in each work through participation of both women and men.

The principal objective of this Strategy [LGED's Gender Equality Strategy] is to develop women and to create women-friendly ambience at all levels of LGED activities in consonance with the incorporation of the National Women Development Policy 2011... [The Strategy] has been formulated primarily to attain the very objective of transforming LGED into an example among the public sector organizations towards promoting gender values. $^{\text {a }}$

The Gender and Development Forum of LGED facilitates the sharing of experiences and lessons learned across projects in LGED. It is mandated to play a role in the planning of various projects by reviewing development project proposals. It is chaired by the additional chief engineer (implementation), and has a senior female engineer as the secretary. The project directors and female engineers of various projects are its members. Its budget is provided by various projects.

It recently led the review and updating of the Gender Strategy in 2014 to make it consistent with the National Women Development Policy (2011) and Women's Development Action Plan (2014). The Gender and Development Forum compiles information from projects and provides yearly awards to individuals by sector for exceptional performance. However, the forum has no staffing or budget of its own.

a Government of Bangladesh, Local Government Engineering Department. 2014. Gender Equality Strategy of the LGED. Dhaka.

\section{Overall Good Practices and Lessons}

Various initiatives from different organizations have been implemented to address specific problems and challenges women (especially those living in poverty) encounter, and which are specific to urban environments. This section will highlight a few examples of good practices and identify some lessons.

Mobilizing community to facilitate women's participation. A policy report concluded that "in most urban contexts in the global South, poverty can only be reduced significantly when urban poor groups and their organizations can influence what is done by the local and national government agencies that are tasked to support them, and when they have the space to design and implement their own initiatives and then scale-up with government support." ${ }^{\circ 8}$ The Urban Partnerships for Poverty Reduction project carried out women's community mobilization with very positive results. Community development projects such as UPPR have begun to make progress on giving the urban populations a stronger voice in the communities and towns, and enabling them to break free of systems of patronage that disadvantage them. See Box 4 for the UPPR experience of community mobilization.

Providing low-cost housing. The Association for Realisation of Basic Needs (ARBAN), an NGO working for the poor in Bangladesh, has built an apartment complex for 42 households in MirpurSection-2. The households have used their microcredit savings for deposit on the land and received housing loan assistance from ARBAN. The architectural design of the housing was done by the Architect-Planner Salma A. Shafi. The owners have contributed to construction, management, and full-time supervision of the project. ARBAN has currently started

\footnotetext{
68 D. Satterthwaite and D. Mitlin. 2013. A Future that Low-Income Urban Dwellers Want, and Can Help Secure. Human Settlements Working Paper Series. No. 38. London: International Institute for Environment and Development.
} 
the process for implementation of a lowcost housing project in Meradia, Khilgaon, and Dhaka. The project consists of two buildings with community facilities. The project beneficiaries will be low-income people who are members of ARBAN and some of the staff members of ARBAN with provisions to ensure ownership by women of a certain proportion of the housing. Without such initiatives, it is difficult for urban women-headed households to gain security of tenure.

Making cities safe. The United Nations Entity for Gender Equality and the Empowerment of Women (UN Women) has launched a worldwide campaign on safe cities for women. A methodology has been developed by UN Women and Jagori, a women's rights organization, in Delhi. In Bangladesh, Action Aid Bangladesh carried out a safety and security audit from a gender perspective in Narayanganj and Barisal. The next step would be for the city corporation to take concrete steps to address the problems the women identified. However, without waiting for top-down interventions, communities themselves can carry out women's and girls' safety audits to identify priority actions to prevent and reduce VAW in the public space, workplace, and home. For example, the Promotion of Legal and Social Empowerment of Women project of GIZ with the Ministry of Women and Children Affairs (MOWCA) had a component on community policing where the community forum members would carry out a mapping of their area to identify where and what kind of "antisocial" activities were occurring, including where women or girls were harassed or attacked. They would then identify what they could do to address the problems and where they would need the help of the police or local government representatives. There are materials and a methodology designed by GIZ and MOWCA that could be used by other agencies and programs for community safety audits. The SafetiPin app was launched in 2016 by Manusher Jonno Foundation, also addressing women's and girls' safety in public spaces. ${ }^{69}$

\footnotetext{
${ }^{69}$ Manusher Jonno Foundation is a human rights and governance funding body in Bangladesh.
}

\section{Recognizing and supporting unpaid} care work. An essential support to enable women to move out of poverty and to allow access to employment is the provision of day care programs in the communities. Many women are not able to undertake wage employment, and have to accept lowpaid home-based work as they do not have support for childcare. Children are left in the slums with no care or supervision, which may lead to abuse or neglect. Two different models of community-based childcare have been piloted in Dhaka. The first model by Phulki, ${ }^{70}$ an NGO, provides training to the caregiver and

\section{Box 4: Community Mobilization in Urban Slums}

The Urban Partnerships for Poverty Reduction (UPPR) project and Urban Governance and Infrastructure Improvement Project (UGIIP) II $^{\mathrm{a}}$ and UGIIP III emphasized community mobilization for poverty reduction:

Effective local social mobilization is at the core of the UPPR approach, with community development committees (CDCs) established by the programme directly driving improvements in living conditions and facilitating better livelihoods.

About 3 out of 4 poor UPPR households have joined one of more than 28,000 primary groups, each of which represents about 20 households and forms the grassroots level of the community governance structure. Almost all members of primary groups (98\%) are women. Other vulnerable social groups represented in primary groups include people with disabilities, ethnic minorities and scheduled castes.

In turn, the primary groups have coalesced into nearly 2,600 CDCs, which are supported to take the initiative to assess their community's physical, social and economic development status, prioritize their needs for poverty reduction, and use data gathered by the community to develop community action plans to address these.

A total of $213 \mathrm{CDC}$ cluster committees have been formed to bring CDCs together for even greater impact and knowledge sharing, and five towns have formed town-wide CDC federations to articulate voices and choices of the urban poor.

Federations in towns are now beginning to be formed, and some cluster leaders have been elected as town councilors and now have the opportunity to advocate for the needs of the urban poor and slum dwellers.

ADB. 2015. Second Urban Governance and Infrastructure Improvement (Sector) Project. Manila (Project Number: 40559-013-BAN).

Source: K.K. Dorji. 2013. Putting Community First: Expanding Voice and Choice for Bangladesh's Urban Poor. Dhaka: Urban Partnerships for Poverty Reduction.

\footnotetext{
70 Phulki or "spark" in Bengali, is a nonprofit organization promoting day care centers in the community and in garments factories. 
some supervision to a childcare program. The program is run by a woman in the slum with a room big enough to keep eight to ten children. The mothers each pay a monthly fee to the caregiver and provide food for their child. The caregiver earns a reasonable monthly income after covering her costs. The second model of community day care is implemented by BRAC under the MEJNIN ${ }^{71}$ Program with the Snehaloy (day care or early childhood development program in urban slums). Such a model is more expensive but provides better quality care for children.

\section{Gender Equality in Urban Development: the ADB Experience}

\section{- Good Overall Practices}

ADB has long implemented urban projects and other interventions with strong gender equality elements. A key instrument to promote and monitor gender mainstreaming in ADB project is the use of gender categories (Box 5). Other ADB good

\section{Box 5: ADB Gender Categorization of Projects}

$\mathrm{ADB}$ classifies a proposed program or project into any of the following gender mainstreaming categories:

(i) Category I: gender equity theme. This is used when the project outcome directly addresses gender equality and/or women's empowerment.

(ii) Category II: effective gender mainstreaming. The project outcome does not specifically address gender equality or women's empowerment, but the project outputs are designed to deliver tangible benefits to women by directly improving access to services, opportunities, infrastructure, and/or enhancing their voices and rigths.

(iii) Category III: some gender elements. The project is by nature likely to directly improve women's access to services, opportunities, improved voice but does not meet effective gender mainstreaming criteria; or it is unlikely to directly improve women's access to services, opportunities, and voice but significant efforts were made to include some gender features to enhance benefits for women.

(iv) Category IV: no gender elements. This is used when a project does not include any gender design features.

Source: ADB. 2013. Tip Sheet No. 1: Understanding and Applying Gender Mainstreaming Categories. Manila.

\footnotetext{
${ }^{71}$ Meyeder Jonno Nirapod Nagorikatto (MEJNIN) (Safe Citizenship for Girls) is one of the key areas of work of BRAC Gender Justice and Diversity Program.
}

practices and lessons regarding addressing gender equality are summarized below.

Effective leadership for urban governance. Good urban governance requires effective leadership by the elected representatives of city corporations and pourashavas with participation of the municipal officials, the central local government agencies, the private sector, NGOs, civil society, and citizens, both men and women. A number of ADB-supported Government of Bangladesh programs have contributed to setting into place structures for citizens' participation, accountability, and transparency, such as neighborhood committees, ward committees, town level coordination committees, and even the city development committee (Nagar Unnayan Committee or City Development Committee). In many of these structures work has been done to ensure participation of women and their representativesthe women ward and town councilors. Although constraints to their authority and jurisdiction remain, their potential and interest have been demonstrated. Elected female representatives have also been able to engage in decisions regarding budgeting and resource allocation-both of project funds and own budgets of the municipalities. ${ }^{72}$

Through the adoption by local governments of tools and processes to enhance transparency and accountability, such as participatory budgeting process, procedures for public petitioning, and codes of ethics for local governments, NGOs and civil society organizations have helped make them more accessible and comprehensible for the poor, the women, and other marginalized groups.

Institutional capacity development of government agencies to address gender. Significant resources are being dedicated to capacity development of the various government agencies active in the urban sector, such as LGED, WASA (Dhaka and Khulna), Urban Development Directorate, and the National Housing Authority. Particular attention is being devoted to human resource development

\footnotetext{
${ }^{72}$ ADB. 2012. The Urban Governance and Infrastructure Improvement Project in Bangladesh. Philippinnes.
} 
of these agencies. However, as technical agencies, they face certain difficulties in mainstreaming gender into their structures, staffing, and management. Women are lagging in professional categories and at senior levels. Gender training is perceived as something for women. ${ }^{73}$ While there has been progress in Dhaka WASA and LGED in adopting gender policies, developing action plans (Dhaka WASA), and assigning gender focal points, progress in achieving practical results is at different levels. The setting up of gender fora in different agencies, such as LGED Gender and Development Forum (Box 3), allows women staff to network, develop capacity, and advocate for common interests. In addition, LGED has established positions of gender focal points in districts and a community organizer in upazilas.

\section{- Good Project Level Practices}

Managing gender mainstreaming. An important element of $\mathrm{ADB}$ projects that are categorized as GEN or EGM (Box 5) is the use of gender action plans (GAPs), which are integrated with the core project activities and monitored through quarterly reports of progress in implementation. Some projects have been able to institutionalize GAPs at multiple levels with goals, targets, and monitoring indicators. For example, Urban Governance and Infrastructure Improvement Project (UGIIP) has GAPs in the pourashavas (municipalities), and guidelines are provided to the pourashava officials. Gender equity theme (GEN) and effective gender mainstreaming (EGM) projects also have institutional anchorsgender focal points nominated by the government authorities from among core senior level staff. To have someone in the institutional structure, who is often assisted by a gender specialist or consultant as and when needed, makes the results more sustainable and creates greater ownership. Regular meetings are held with the gender focal point of projects, as well as annual meeting of project directors and gender anchors at project level, with ADB officials. Another important part of the gender mainstreaming practices is the institutionalization of the collection

\footnotetext{
${ }^{73}$ Maheen Sultan. Interview with project consultants. Dhaka 2016.
}

and use of sex disaggregated data, regular monitoring, and indicators. As already mentioned, LGED has a monitoring and evaluation unit, which has capacity in this regard. It has also set up a gender information management software to monitor gender and development data by the Gender and Development Forum.

Formulating contractual obligations. ADB-assisted projects have been able to integrate provisions related to gender mainstreaming into loan conditions of the agreement between the Government of Bangladesh and ADB. Gender-related clauses are also integrated into contractors' agreements-working conditions, separate toilets, day care, equal pay. These give strong legal basis, and can also allow for corrective action if necessary. These place gender-related provisions on a par with other institutional and financial provisions. Providing orientation to the contractors on the legal obligations in this regard reemphasizes the importance $\mathrm{ADB}$ and the government agencies attach to these.

Setting employment targets. A number of project GAPs have set employment targets for women which have had a positive effect in focusing attention on this through regular monitoring. While it is important to set realistic targets, ${ }^{74}$ it is also important to bring into consideration issues of working environments. This includes ensuring that the working environment and facilities provide for women's needs and decent working conditions. It is relatively easy to recruit female staff responsible for community organizing, women laborers to do earthwork, and women health staff at lower levels as these are traditionally seen as women's activities and responsibilities. However, meeting employment targets for staff at more senior levels and in more specialized or technical jobs needs more of a concerted effort.

Increasing women's leadership. A good practice that addresses various dimensions at the same time is strengthening women's

\footnotetext{
${ }^{74}$ This is based on the experience of ADB's Teaching Quality Improvement (TQI) Project on setting of goals related to project loan disbursements, which is discussed further in the chapter on Skills, Vocational, and Tertiary Education Sector.
} 
leadership by working with female elected representatives and enabling them to fulfill their roles and responsibilities by involving them in project activities and by providing them with resources to carry out their responsibilities. The effectiveness of locally elected female representatives depends on how well they can listen, represent, and address the needs and concerns of their constituents. The UGIIP in Bangladesh initiated courtyard meetings to link women councilors with poor female voters so that they could listen, learn, and understand the priorities of women in the municipalities.

Institutionalization strategies. There are several good practices that will also enable greater sustainability of GEN and EGM project initiatives. One of these is working within the legal framework, e.g., Pourashava Act, at local government level and its provisions for a standing committee for women's development and participatory planning. Integrating gender mainstreaming into institutional policies and strategies and gender forums such as in LGED goes beyond individual projects. This is being attempted in Dhaka WASA by having an institutionalized gender policy, and through the integration of gender elements in the training policy and program and into the HR policy. Working at multiple levels is necessary, such as addressing policies and program design, interacting with providers and users, and developing budget allocations. Finally, ensuring necessary resource allocation, such as through central or local government budgets as has been done in UGIIP-supported pourashavas, is a means of ensuring that activities will continue even after projects are completed.

Promoting women's economic activities and employment. Some of the projects have provided employment opportunities for women, e.g., in construction and community outreach. GAP of the City Region Development Project included plans to reduce wage gaps between women and men and ensure adherence to core labor standards. Under UGIIP, women also benefited from microfinance and income-generating activities. Within the community development committees, primary groups and savings and credit groups were formed with about $95 \%$ female membership under Phase I. ${ }^{75}$

Providing women-friendly physical infrastructure. Some projects have focused on providing physical infrastructure that create conditions for women to be present and active in public spaces by increasing their security and comfort, and addressing their needs-e.g., construction of waiting rooms in bus terminals, public toilets (by City Region Development Project), and improvements in streetlighting and ticket counters in bus stations (UGIIP). Under UGIIP II, separate counters have been set up as one-stop services in 42 municipalities for women to avail, and 47 municipalities have set up rest and breastfeeding corners for women. Individual municipalities have taken such initiatives on their own, e.g., Chandpur Municipality setting up public toilets and benches in a public park. ${ }^{76}$

Improving access and outreach. The Second Urban Primary Health Care Project also established some important project level good practices. It was found that improving women's access to public health care can be done through locating health care facilities near the poor and urban households, and this can also increase access for the poorest families. Courtyard meetings and door-to-door counseling are effective ways to raise awareness and to support the adoption of good health practices including hygiene, child health, and reproductive health.

Involving men and boys. The Second Urban Primary Health Care Project has yielded important lessons on the advantages of involving men. ${ }^{77}$ Mother and child health should be placed in a broader context and steps taken (such as work with men and other family members) should be expanded. It is important to address men's responsibility in reproductive health. It is important to have more male staff at

\footnotetext{
${ }^{75}$ ADB. 2012. Completion Report: Urban Governance and Infrastructure Improvement (Sector) Project. Manila.

${ }^{76}$ ADB. Draft. Completion Report: Second Urban Governance and Infrastructure Improvement Project. Manila.

77 ADB. 2015. Gender Equality Results Case StudyBangladesh: Second Urban Primary Health Care Project. Manila. pp. 11-12.
} 
different levels, especially at the outreach levels, to reach men and boys. To reduce VAW, it is important to work with men and boys so that they do not consider VAW to be a normal phenomenon and develop greater respect for human rights. ${ }^{78}$

\section{- Common Challenges}

Despite considerable achievements and innovation, there are areas that can be strengthened further:

- The institutionalization of changes related to gender mainstreaming is challenging as it requires, among other things, strengthening governance in local government bodies and in sectors; supporting the institutional development of government agencies, including their technical capacity for gender analysis and programming; improving interagency coordination and partnerships; and creating enabling environments so that gender equity issues can be addressed.

- Resource constraints are a challenge. They include the need for more technical support from ADB Bangladesh Resident Mission for addressing genderrelated objectives and activities, and for more technical expertise in project teams, both on the government side and in consultant teams. While projects may emphasize capacity building, unless the necessary staff and resources are in place the capacity cannot be put into use.

- In several project interventions, steps have been taken to involve local communities, particularly women, children, and persons with disabilities, in decision-making and in setting priorities for the provision of services and infrastructure. There is a possibility that the organizations and resources will not be able to cope with the increased demand. User fees and charges may be one of the means of managing demand as long as women's differential access to, and control over, money is taken into account.

- While increasing employment of women has been recognized as a priority in many projects, there remains the need to break stereotypes so that women can enter and remain in nontraditional sectors, roles, and jobs. It is also important to influence larger change processes so that women will be able to make educational and professional choices that will bring them into technical fields such as engineering, architecture, transportation, and construction.

- While local economic development is an important function of urban local government bodies, this is generally addressed in a limited manner. However, the scope for promoting local economic development is wider and could consider setting up specific economic zones through land use planning for different types of industries or giving incentives to different industries or businesses.

- Although there is an increasing awareness of VAW being a barrier to women's participation, mobility, and as violation of human rights, there is still room to further integrate action for prevention into project design and activities.

\section{Strengthening Gender Equality Approaches}

This section outlines the possible actions to strengthen gender equality approaches in the urban sector. Annex 1 provides a tip sheet on integrating gender perspectives in urban development projects. Annex 2 provides a list of useful resource materials.

\footnotetext{
${ }^{78}$ Footnote 77 (Gender Equality Results Case Study Bangladesh: Second Urban Primary Health Care Project), pp. 11-12.
} 
A. Review and revise rules and regulations of the local government bodies that are being implemented to clarify provisions for women's representation in various committees and citizens' representation, and to provide equal rights and responsibilities.

B. Include in planning at all levels the perspectives and priorities of women from various socioeconomic, age, and professional groups by specifying at least one-third representation of women.

\section{Institutional Capacity Development of Government Agencies}

C. Consider the gender implications of institutional reforms for better urban governance with reference to the institutions' gender strategies (e.g., LGED and WASA).

- Review and revise human resources, training, finance, and other institutional practices for gender mainstreaming;

- Take special measures to increase the number and representation of women in decision-making and technical specializations; and

- Create an enabling environment for women to work comfortably alongside men.

D. For ADB BRM to dedicate adequate human resources for social development from varied backgrounds with experience relevant to specific project types.

E. For MOWCA to play oversight role in advising, guiding, and monitoring institutional strengthening of government institutions in terms of gender mainstreaming. MOWCA's role and responsibilities at various levels formalized through memorandums of understanding with other government agencies.

\section{Strengthening Women's Leadership}

F. Promote the development of the leadership skills and capacity of locally elected female representatives to fulfill their roles and responsibilities through involvement in program planning, community mobilizing, and networking among themselves. This may be made into performance criteria for receipt of block grants. Horizontal learning and exchanges can facilitate the dissemination and adoption of best practices in this area.

\section{Resource Allocation}

G. Provide adequate budget for the implementation of gender strategies and action plans whether it be from tax collection or from the central government budget.

H. Subject municipality and city corporation budgets to the same kind of screening as national budgets and prepare and evaluate them through a gender-responsive budgeting process, i.e., all budget allocations are analyzed for their potential impact on women and men. A minimum percentage, e.g., $30 \%$ of the overall budget, would have to be allocated for activities, services, staff that would benefit women.

\section{Responsibility}

Government of Bangladesh (Ministry of Local

Government, Rural Development and Cooperatives) in collaboration with local government institutes and civil society organizations

Government agencies, local government institutes, projects and civil society organizations

Government agencies, local government institutes and projects

$\mathrm{ADB}$

Ministry of Women and Children Affairs (MOWCA)
Government agencies, local government institutes, and projects in collaboration with women's organizations and MOWCA 


\begin{tabular}{|l|}
\hline Action Areas \\
Monitoring and Evaluation \\
I. Strengthen the monitoring and reporting of project and \\
institutional GAPs and integrate into the institutional \\
management information system. \\
- Ensure the collection, analysis, and use of sex-disaggregated \\
information at all levels; \\
- Embed monitoring responsibilities in the project \\
management units (not inly in consultant contracts) and \\
assign specific responsibilities to senior management \\
and monitoring and evaluation units for demanding, \\
disseminating, and using sex-disaggregated data.
\end{tabular}

\section{Employment Targets}

J. Continue setting project employment targets for women at all levels as this is effective in keeping attention focused on the issue. There is a need to set minimum qualifications required for different posts-to allow the hiring of women. Government quotas may need upward revision. Stereotypes about what jobs women are suitable need to be gradually changed and women supported to break them by providing safe and comfortable working environments.

\section{Institutionalizing Change and Sustainability Strategies}

$\mathrm{K}$. Integrate progressive provisions within the legal framework such as the Local Government Act 2009 and its stipulations for women's representation and their functions, the creation of standing committees, etc., used to provide legitimacy, promote sustainability, and further women's leadership.

L. Strengthen the capacity of staff, NGOs, and contractors in addressing gender issues.

M. Consistently integrate gender responsive requirements (e.g., on core labor standards, working conditions and facilities, safety and security) in all urban projects and contractors' legal and contractual obligations (standard bid documents).

\section{Public-Private Partnerships (PPP)}

$\mathrm{N}$. For the government to monitor compliance of the private sector with government policies and principles regarding gender equity and mainstreaming in the provision of urban housing, infrastructure, and services.

\section{Responsibility}

Government agencies, local government institutes and projects

Government agencies, local government institutes and projects, MOWCA

Government agencies and projects, development partners

Government agencies and projects, and development agencies

Government agencies, local government institutes and projects

Government, Local Government Division, local government institutes 


\section{Annex 1: Tip Sheet on Questions and Design Features for Gender Mainstreaming in Urban Development Projects}

\begin{abstract}
Illustrative outcomes of projects and related possible gender equality outcomes $^{\mathrm{a}}$ Improved services

New or upgraded urban water supply, sanitation, and waste disposal

- Better reflection of women's priorities in selection of infrastructure investments

- More women-friendly design and placement of infrastructure and increased personal safety

- Decreased workloads and time spent for women to meet household water and sanitation needs
\end{abstract}

Increased access to water and sanitation supply with improved service standards.

- More households with connections, decreasing demands on women's time and effort

- Better conditions for women's personal dignity and safety
Examples of questions to consider in analyses to formulate project strategies and gender-related design features

- What do women identify as their water and sanitation needs and priorities? How does this compare with men's?

- What are women's views on issues such as number and location of facilities (pumps, toilets); sharing vs. individual facilities; types of latrines; etc.?

- Are women's voices in community discussions and decision-making about water supply and sanitation adequate to meet their extensive household responsibilities for water and hygiene?

- Has the approach to service delivery in poor and slum areas considered how to overcome obstacles that poor households could face, particularly the lack of formal title or tenure to their dwelling?

- What are the safety issues related to location of water points and design and location of latrines that could be addressed through project plans and designs?
Examples of possible gender-related design features, measures, and activities that might be relevant (or adaptable)

- Ensure that consultations identify issues of women and men separately to better respond to needs.

- Give priority to women's views for type, design, and location of household or community water supply, toilet facilities, and waste collection.

- Emphasize separate toilet provisions for women in low-income communities.

- Explore options to ensure that procedures for connection, billing, and payment do not exclude poor women and poor households.

- Consider the potential for policy reform to delink service provision to households from tenure arrangements.

- Where toilets are not private, design and locate them so that women can reach and use them safely.

\section{Employment opportunities}

Expanded employment and income opportunities associated with new facilities and services

- Equitable access to employment and income opportunities generated in management, delivery, or maintenance of new and upgraded services

- Improved opportunities, productivity, and incomes for women
- What are the opportunities for employment related to management of new facilities (e.g., monitoring of functioning, or metering and billing processes)? Or in maintenance of new facilities (e.g., cleaning, repair)?

- What types of work do women do (considering casual labor, domestic service, market trading, home-based production, etc.)?
- Encourage municipal authorities managing new facilities to target women for training and employment in community-based management and maintenance.

- Consider the potential to involve women's enterprises or self-help groups for management of tasks such as meter reading, billing, or consumer information, or for maintenance tasks. 
Annex 1 continued

\section{Illustrative outcomes of projects and related possible gender equality outcomes $^{\mathrm{a}}$}

\section{Examples of questions to consider in analyses to formulate project strategies and gender-related design features}

- What are the specific constraints faced by women in slum areas in finding and keeping adequate jobs and incomes? Are these related to the context (e.g., transport options, time demands of inadequate services, limited employment on offer)? What are the constraints related to capacities (e.g., literacy, vocational, or management skills, etc.)?

- If involvement of self-help groups is envisaged, what are their strengths and weaknesses? What are their livelihood activities? What is the potential to form viable affinitybased groups?

Employment arising from project construction work

- Equitable access to temporary project jobs

- Better recognition of women's rights to equal pay and appropriate working conditions
- Are women active in the construction sector in the project area? How do skill and pay levels compare with men's?

- Are workers and employers and/ standards and workers' rights, including women's rights to nondiscrimination and equal pay? or contractors aware of core labor
Examples of possible gender-related design features, measures, and activities that might be relevant (or adaptable)

- Partner with nongovernment organizations to develop programs for skills training, entrepreneurship training, and support.

- If self-help groups are part of the project livelihoods strategy, ensure that the project allocates the support necessary to form and/or sustain viable groups.

- Increase linkages of women and women's self-help groups to government programs supporting livelihoods (skill training, entrepreneurship support).

- Set targets for women's participation at different skill levels that are meaningful and achievable (given labor supply, local conditions, etc.).

- Brief contractors on their responsibilities for equitable pay and working conditions.

\section{Governance and management}

Effective citizen participation in urban planning process, slum redevelopment planning, and other community committees

- Increased opportunities for women to voice their interests and participate in decision-making

- Increased capacity of men in the community to work productively with women

- Support to minority communities and those with special needs

Strengthened governance capacity and practices of urban local bodies (elected members and staff)

- Elected representatives and staff better informed about the needs of women in the areas they serve

- More informed and skilled women councilors and ward members

- Employment of female in the lower grade jobs, e.g., cleaners.
- What are the gender dynamics of participation in this locality? For example, are women equitably represented, do they have the opportunity or the confidence to voice their views, do men listen, and do women's views influence discussions and decisions?

- Do men accept women's participation in these committees and support decisions that provide benefits to women?

- How do male councilors and ward members see their responsibilities to women citizens, as users of services and as citizens?

- Do poor women have access to committee members and/or councilors?

- Are elected women participating in and chairing key ward and council committees? If not, why not?
- Work with municipal authorities to ensure that citizen participation plans respond to the identified constraints on women's participation (e.g., times and locations that allow women to attend, focus groups with women if there are difficulties in participating in mixed groups, supporting men to work constructively with women).

- Partner with women's advocacy organizations to provide training to elected officials (both women and men) about women's issues in the municipality.

- Facilitate linkages with government programs to train women councilors.

- Facilitate linkages and networking with elected women in other municipalities to exchange experience and strategies. 
Annex 1 continued

\section{Illustrative outcomes of projects and related possible gender equality outcomes $^{\text {a }}$}

Strengthened management capacity of state departments and municipal agencies

- Increased responsiveness of management and staff to gender differences in needs and priorities

- Improved data and skills for gender responsive policy and program development

Successful resettlement of those displaced by new infrastructure or restoration of women's livelihoods and income

- Maintenance or rebuilding of social networks

- Strengthened property rights of women
Examples of questions to consider in analyses to formulate project strategies and gender-related design features

- Do the information systems of the agency generate the sexdisaggregated data required for analyses of needs, options, and outcomes (e.g., data on use of public transport or managers of market stalls)?

- Do the agency's criteria for infrastructure choices or designs include attention to how they affect women's safety (e.g., role of streetlighting, bus bays, pedestrian walkways, protected access to public toilets)?

- Are there barriers to women's participation in consultation processes (related to, for example, transport availability or costs, household duties, local social mores)?

- How does displacement and resettlement affect women's livelihoods? Are there adequate and affordable transport services to reach places of employment? Can previous livelihoods in self-employment or trade be reestablished and be viable? What other services have been disrupted (e.g., childcare, schooling)?
Examples of possible gender-related design features, measures, and activities that might be relevant (or adaptable)

- Allocate resources and expertise to improving data systems so they generate sex-disaggregated data, and to improving analytic skills among planners for use of such data.

- Assist partner state or municipal agencies to develop linkages with research and advocacy organizations concerned with urban women's issues (to provide training, feedback, research inputs, etc.).

- Develop a consultation strategy that addresses the barriers identified to ensure that different categories of women are reached (households headed by women, widows, married women, single women).

- Develop and fund a plan to facilitate reestablishment of livelihoods (responding to findings of needs analysis).

- Follow up government commitments to strengthen women's land rights in resettlement processes (equitable land allocations to women and direct transfers to women).

Related possible gender equality outcomes refer to changes that reduce gender gaps or otherwise benefit women. 


\section{Annex 2: Useful Resources for Further Reading on Gender Equality in Urban Development}

\begin{tabular}{|c|c|}
\hline $\begin{array}{l}\text { Bangladesh-specific research } \\
\text { and analyses on gender and } \\
\text { urban development }\end{array}$ & $\begin{array}{l}\text { - F.S. Begum. 2014. Gender Equality and Women's Empowerment: Suggested Strategies for } \\
\text { the 7th Five Year Plan. Dhaka: General Economics Division, Planning Commission. } \\
\text { - S.A. Shafi. 2010. Women's Safety in Relation to Issues of Urbanization, Land } \\
\text { Tenure, Social and Physical Infrastructure Development: Case of Dhaka City. Third } \\
\text { International Conference on Women's Safety: Building Inclusive Cities. } \\
\text { New Delhi. 22-24 November. }\end{array}$ \\
\hline $\begin{array}{l}\text { Bangladesh-specific resources on } \\
\text { safe cities for women }\end{array}$ & $\begin{array}{l}\text { - Government of Bangladesh, Ministry of Women and Children Affairs. 2013. National } \\
\text { Plan of Action to Prevent Violence Against Women and Children 2013-2025. Dhaka. } \\
\text { - R.T. Naved et al. 2011. Men's Attitude and Practices regarding Gender and Violence against } \\
\text { Women in Bangladesh. Dhaka: icddr,b. }\end{array}$ \\
\hline $\begin{array}{l}\text { Other research and analysis articles } \\
\text { on gender and urban development }\end{array}$ & $\begin{array}{l}\text { - S. Chant. 2007. Gender, Cities, and the Millennium Development Goals in the Global } \\
\text { South. New Working Paper Series. No. 21. London: London School of Economics, } \\
\text { Gender Institute. } \\
\text { - D. Peters. 2011. Gender and Sustainable Urban Mobility. Thematic study prepared for } \\
\text { Sustainable Urban Mobility: Global Report on Human Settlements 2013. Nairobi. } \\
\text { www.toronto.ca/legdocs/mmis/2012/cc/bgrd/CC20_1_app3_24.pdf } \\
\text { - Equations. 2007. Women in Tourism: Realities, Dilemmas and Opportunities. } \\
\text { 15 September. www.equitabletourism.org/readfull.php?AID=419 } \\
\text { - D. Satterthwaite and D. Mitlin. 2013. A Future that Low-Income Urban Dwellers } \\
\text { Want, and Can Help Secure. Human Settlements Working Paper Series. No. 38. London: } \\
\text { International Institute for Environment and Development. } \\
\text { - Urban Partnerships for Poverty Reduction. 2015. Now I Can: Measuring Women's } \\
\text { Empowerment in Poor Urban Areas. Dhaka. } \\
\text { - Women in Cities International. 2010. Learning from Women to Create Gender Inclusive } \\
\text { Cities: Baseline Findings from the Gender Inclusive Cities Program. Montreal. }\end{array}$ \\
\hline $\begin{array}{l}\text { Guides and case studies on gender } \\
\text { and urban development }\end{array}$ & $\begin{array}{l}\text { - World Bank. 2010. Making Urban Development Work for Women and Men: Tools for } \\
\text { Task Teams. } \\
\text { - Women Watch. 2009. Gender Equality and Sustainable Urbanisation: Fact Sheet. } \\
\text { http://www.un.org/womenwatch/feature/urban/downloads/WomenWatch_Gender_ } \\
\text { Equality_and_Sustainable_Urbanisation-fact_sheet.pdf }\end{array}$ \\
\hline $\begin{array}{l}\text { ADB practical resources for project } \\
\text { planning and management in } \\
\text { the sector }\end{array}$ & $\begin{array}{l}\text { - ADB. 2006. Gender, Law, and Policy in ADB Operations: A Tool Kit. Manila. https://www. } \\
\text { adb.org/documents/gender-law-and-policy-adb-operations-tool-kit } \\
\text { - ADB. 2003. Gender Checklist: Resettlement. Manila. https://www.adb.org/sites/default/ } \\
\text { files/publication/28731/gender-checklist-resettlement.pdf } \\
\text { - Other ADB gender checklists and toolkits are currently available for a number of } \\
\text { themes (including water supply and sanitation, urban development and housing), } \\
\text { and others are planned (including one on public sector management). www.adb.org/ } \\
\text { themes/gender/checklists-toolkits } \\
\text { - ADB. 2009. Briefing Note: Project Gender Actions Plans, Lessons for Achieving Gender } \\
\text { Equality and Poverty Reduction Results. Manila. https://www.adb.org/sites/default/ } \\
\text { files/publication/29008/gender-briefing-note.pdf } \\
\text { - Further resources and guides on gender action plans: www.adb.org/themes/gender/ } \\
\text { project-action-plans }\end{array}$ \\
\hline
\end{tabular}




\section{Transport Sector}

\section{Summary}

Transportation is a major catalyst of economic growth and poverty reduction, but despite large investments, various constraints limit its potential benefits for various geographical areas and population groups such as women and children. The transport sector includes rail, water, air, and road transport, as well as pedestrian mobility. In view of the dominance of road transport and pedestrian mobility, this chapter will mainly concentrate on these.

Women are both users and transport providers. Women's mobility needs have increased over the years with more women getting an education and entering the workforce. The nature of mobility and gender constraints in urban and rural transportation is different. Women's accessibility also needs to be considered separately from mobility. The involvement of women in the public and private transport sector as employees, managers, business owners, and partners is low. Due to the lack of skills training, women find it hard to compete with male transport workers. Enrollment of women in major technical universities, which is a prerequisite to encourage women to join the workforce in the transport and infrastructure sector, is low.

The Seventh Five Year Plan mentions the importance of transportation as part of gender-responsive working environment. The institutional structure of the transport sector involves four types of broad subsectors: road, railway, water, and air. Each of these sectors includes different agencies and organizations. Various private sector transport operators work alongside these agencies.

Examples of good practices in promoting gender equity in transportation include the "avoid-shift-improve" approach applied to the Greater Dhaka Sustainable Urban Transport Project, which allows greater gender responsiveness. ${ }^{79}$ Community policing has been used to promote road safety awareness and practices. SafetiPin, a mobile phone app, is being tested to increase road safety for women. The transport sector accounts for the second largest number of loan and technical assistance (TA) projects of the Asian Development Bank (ADB) in Bangladesh and provides valuable experience in addressing gender. Transport projects implemented by the Local Government Engineering Department (LGED) benefit from the same institutional measures used for LGED urban projects, such as the LGED Gender and Development Forum and LGED Gender Equality Strategy. The LGED transport projects include capacity building of government agencies and local government bodies such as the municipalities (in the Urban Governance and Infrastructure Improvement Project [UGIIP]) and the union parishads (in Sustainable Rural Infrastructure Improvement Project [SRIIP]). ${ }^{80}$ Targets of female staff or the employment of women as laborers and in the labor contracting societies (LCS) both for construction and maintenance are set. Special emphasis is given in some projects to women as passengers, and various measures are taken to ensure their use of the transportation, safety, and comfort. Another good practice is the use of a TA project to test out and introduce practices in a project loan that can promote gender equality. The final section outlines the possible actions to strengthen gender equality approaches in transport sector development. Annex 1 provides a tip

\footnotetext{
$79 \quad$ ASI was developed during the 2011 Bogotá Declaration with the objective of promoting an alternative mobility solution and developing a sustainable transport system.

80 ADB. 2016. Sustainable Rural Infrastructure Improvement Project. Manila (Project 40515-013BAN).
} 
sheet on integrating gender perspectives in transport development. Annex 2 provides a list of useful resource materials.

\section{Sector Context}

The national transport sector consists of urban and rural roads, railways, air, and water transport services. The urban and rural road transportation system consists of national, regional, and local networks and service sectors. The service sector includes a range of motorized transport and nonmotorized transport (NMT) services with their supporting production employment and management subsectors.

The railway service is spread over most of the country except the hilly regions and the coastal belt. As of fiscal year (FY) 2015 , there were 2,877 kilometers $(\mathrm{km})$ of railway track. A measure of messenger traffic is passenger per $\mathrm{km}$, which showed an increase from 7,305,000 in FY2010 to 9,091,170 in FY2015. ${ }^{81}$

Historically, the Government of Bangladesh has been well connected by a water transportation network, including with other countries. The water transportation network has also been functioning since the British rule of the Indian subcontinent. Most of the urban and rural centers now have river ports and transportation for people and goods. However, despite the low cost, freight and passenger water transportation is not used to its full potential due to inadequate dredging and berthing facilities. The review of performance done for the Seventh Five Year Plan has also identified a decline in users due to the decline in management and services, which is also related to the lack of resources invested in the subsector. Another factor is the overloading of passengers, which causes accidents and deaths. The air transport sector has limited use, and connects major urban centers within the country; international airlines are operating mainly through the Hazrat Shahjalal International Airport, Dhaka.

Improving the transport system is a major strategic objective of the Perspective Plan of Bangladesh (2010-2021). The plan

\footnotetext{
${ }^{81}$ Footnote 40 (Seventh Five Year Plan), p. 348.
}

can be a catalyst of economic growth and poverty reduction because of its potential contribution to connecting people to goods, services, resources, and economic opportunities, as well as to the expansion of markets and enhancement of regional trade and investments. Consequently, according to the Government's Sixth Five Year Plan (2011-2015) and Seventh Five Year Plan (2016-2020), most development expenditures (38.5\% in FY2015) of the government and its development partners are on the transport sector. The Sustainable Development Goals (SDGs) and targets also address transportation, specifically the negative impact of road traffic accidents on healthy lives and well-being (Goal 3, Target 3.6). Goal 9, Target 9.1 seeks to "develop quality, reliable, sustainable and resilient infrastructure, including regional and transborder infrastructure, to support economic development and human wellbeing, with a focus on affordable and equitable access for all." Also under Goal 11, which is about making "cities and human settlements inclusive, safe, resilient and sustainable," Target 11.2 is aimed to "by 2030, provide access to safe, affordable, accessible and sustainable transport system for all, improving road safety, notably by expanding public transport, with special attention to the needs of those in vulnerable situations, women, children, persons with disabilities and older persons." ${ }^{22}$

Weaknesses in coverage and access remain. A review of the current state of the transport system in the country shows that the large investments on transport sector development have not covered all areas. Many places in the rural areas remain remote and physically cut off from other parts of the country during certain times of the year and weather conditions, especially in the chars (sandbanks), haors (lowlands), and some coastal areas. In the urban areas, the rapidly growing population is exacerbating

\footnotetext{
82 http://www.un.org/sustainabledevelopment/ health/

HYPERLINK "http://www.un.org/ sustainabledevelopment/infrastructureindustrialization/" $\backslash 1$ "d6c8el2dbefa1065e" $\backslash \mathrm{t}$ “_blank” http://www.un.org/ sustainabledevelopment/infrastructure-industri alization/\#d6c8e12dbefa1065e http://www.un.org/sustainabledevelopment/ cities/
} 
the state of the urban transport system. Specifically, Dhaka, Chittagong, and other cities and towns of Bangladesh are beset with severe transport problems. Demand for transport has outstripped road capacity and provision of viable transport services. Road congestion is affecting efficiency, productivity, public health, and safety. Overloaded roads and streets have resulted in high levels of air and noise pollution. In this situation, vulnerable groups, including children, women, the elderly, and persons differently challenged, are the most adversely affected.

Private sector providers dominate the public transport operations. This includes informal and paratransit ${ }^{83}$ motorized transport and NMT vehicles such as motorcycles, motor rickshaws, auto rickshaws, minibuses, vans, jeepneys, and human haulers. ${ }^{84}$ This system, as discussed in the next section, is also problematic with vulnerable groups, women being affected the most. This situation can be further improved with more partnerships between the government and the private sector in improving the mass and paratransit public transport systems in the country.

\section{Key Gender Issues in the Sector}

To ensure that vital investments in the transport sector contribute to socially inclusive growth, it is essential to track the extent to which they benefit a large segment of the society, including poor women and marginalized groups, and contribute to increasing gender equity. It is also important to identify the barriers to women's (compared to men's) greater benefit from these investments. In this pursuit of gender equity, ADB along with other development partners have played an important role over 3 decades, particularly in the roads, rails, ports, and urban transport subsectors. ${ }^{85}$

This section presents the gender issues in the transport sector from a two-pronged

\footnotetext{
${ }^{83}$ ADB. 2012. Sustainable Urban Transport: Dhaka Bus Rapid Transit Walkability Strategy. Manila.

${ }^{84}$ Footnote 83.

85 ADB. 2009. Country Partnership Strategy Midterm Review: Bangladesh, 2006-2010. Manila. p. 7.
}

perspective of women as transport users and as transport service providers.

\section{-Women as Users: Mobility Aspects}

The large-scale movements of people, objects, capital, and information across the world, as well as more local processes of daily transportation, movement through public and private spaces, and transport of material things in everyday life are considered mobility. Mobility encompasses patterns and processes of men's and women's movement in public spaces, as well as movement and travel in villages, cities, and regions. It also includes men's and women's movement in the local and neighborhood areas, both urban and rural.

Women's mobility needs have increased over the years. This is due to more women entering the workforce while remaining primarily responsible for accessing basic services (e.g., bringing children to school and health facilities, going to the market, etc.) for their families. The resulting weakening of social barriers such as purdah or seclusion has also allowed more girls and women to go out of their houses and communities to study, visit relatives, do outdoor household tasks and other outdoor activities. These social norm changes and economic challenges have pushed women to travel in unfriendly, hostile, and unsafe environments. For instance, $64.3 \%$ of 600 women respondents of a survey had experienced crime and violence in Dhaka's public space. ${ }^{86}$

Riverine transport has become almost extinct except for some routes. Railway transport is not available in many areas. This chapter will therefore be mainly discussing the major modes of transportation and mobility-road transportation and walking.

The nature of mobility and gender constraints in urban and rural transportation is different. In urban areas women travel long and short distances, and have diverse transport needs by age and occupation. There is a lack of reliable public transport, and local transports are not safe and economical. Roads are undeveloped and footpaths are rare. Women's activities are

\footnotetext{
${ }^{86}$ S.A. Shafi. 2010. Urban Crime and Violence in Dhaka. Dhaka: The University Press Limited. p. 91. 
very much hampered by the lack of access to good public transport. At the same time, poor road and footpath conditions and safety issues make walking or riding rickshaws and cycles difficult. Public transportation such as buses reserve few seats for women, resulting in the vulnerability of women to sexual harassment. Added to these are the lack of inadequate transport waiting areas or sheds and inadequate toilet facilities in terminal stations, affecting women's and girls' mobility negatively.

In rural areas, women travel short distances by foot or NMT. Roads are unsafe and often undeveloped. There is a lack of accessibility to social services and low-cost transport services. For long-distance travel, bus is the only transport. Rural women find it difficult to travel even in emergency needs. Young girls have problems going to high schools and colleges far away from home, with sexual harassment being a common problem.

There are numerous constraints on walking. Women in lower-income groups, both in urban and rural areas, often walk to work as is the case for $71.8 \%$ of garment workers. ${ }^{87}$ Walking is, however, constrained by lack of or overcrowded sidewalks, lack of lighting, badly maintained roads, and nonobservance of traffic rules. ${ }^{88}$ The air and noise pollution is a threat to the health of pedestrians and those using public transport, especially the children and the elderly. The lack of rural road sidewalks makes walking riskier with the increasing volume of traffic.

Next to walking, the use of rickshaws or other cheap transport is most prevalent, which is also hampered by bad road connections, irregular services, unsafe conditions, and lack of security especially at night. ${ }^{89}$ Furthermore, culturally and

\footnotetext{
${ }^{87}$ M.K. Shefali. 2000. Study on Gender Dimension in Dhaka Urban Transport Project.

${ }^{88}$ This is mentioned in a focus group discussion with the garments workers of Mohammadi Group for the Gender Equality Diagnostic (GED) preparations in October 2015.

89 S.A. Shafi. 2004. Spatial Growth of Dhaka, Metropolis: Transportation Needs and the Rickshaw as an Important Mode of Transport. Bimonthly Magazine on Public Services, Development and Administration. Good Governance India. 1 (4). Sep-Oct.
}

financially, there are many obstacles to women independently owning and using bicycles, motorcycles, and cars.

Data on road accidents and pedestrian casualty by sex shows that as the number of women on the move increases, the number of women having accidents also increases. The Accident Research Institute of Bangladesh University of Engineering and Technology in 2003 showed that $10.32 \%$ of the total casualties were women. This increased to $20.16 \%$ in 2013 , showing an increase in road accidents of women.

Women's accessibility also needs to be considered separately from mobility. Women's constraints to access reliable transportation are different from that of men in terms of pricing, timing, and physical constraints (e.g., height of door, stairs, and footpath). There have been studies on the availability of public toilets which have highlighted the constraints of availability, accessibility, and cleanliness..$^{90}$ The lack of secure and clean waiting rooms and prayer rooms in bus terminals, ferry terminals, and train stations also creates constraints for women. Unless overbridges are free of hawkers and squatters, women (and men) are reluctant to use them. There are also issues regarding the accessibility of footpaths, which are often used by hawkers, for the storage of building materials or taken over by street dwellers or used by motorcyclists.

\section{- Women as Transport Sector Providers: Present Employment and Future Opportunities}

Women's involvement in the transport sector is low. The involvement of women in both the public and private transport sector as employees, managers, business owners, and partners is low at $1.51 \% .{ }^{11}$ This situation is more pronounced in urban areas than in rural areas-the percentage of female employees in transport sector is $1.06 \%$ in urban areas and $7.93 \%$ in rural areas. ${ }^{92}$ This difference is most likely that unskilled women are getting jobs as laborers

\footnotetext{
${ }^{90}$ Studies done by WaterAid Bangladesh and Centre for Urban Studies.

${ }^{91}$ Government of Bangladesh, Bangladesh Bureau of Statistics. 2011. Labour Force Survey 2010. pp. 55-56.

92 Footnote 91.
} 
in rural areas. In addition to various social and cultural constraints, another barrier is the lack of technical skills and education. Female employment rate is very low in the informal transport sector. Job conditions and work environment are also poor especially for women from low-income groups. Women in unskilled jobs are mostly laborers or maintenance workers. This type of employment was initially promoted through various externally funded rural infrastructure development projects. Gradually it has become more usual for women to take up unskilled labor work in transport and other sectors in both urban and rural areas. Problems of health and

\begin{tabular}{|l|c|c|c|c|}
\hline \multicolumn{5}{|c|}{$\begin{array}{c}\text { Table 8: Number of Male and Female Students } \\
\text { in Major Private Universities of Bangladesh }\end{array}$} \\
\hline & $\begin{array}{c}\text { Total } \\
\text { Students }\end{array}$ & $\begin{array}{c}\text { Male } \\
\text { Students }\end{array}$ & $\begin{array}{c}\text { Female } \\
\text { Students }\end{array}$ & $\begin{array}{c}\text { Female } \\
\text { Students }\end{array}$ \\
\hline University & 13,990 & 9,506 & 4,484 & 32.1 \\
\hline North South University & 4,203 & 2,336 & 1,867 & 44.4 \\
\hline $\begin{array}{l}\text { University of Science and } \\
\text { Technology Chittagong }\end{array}$ & 6,843 & 4,635 & 2,208 & 32.3 \\
\hline $\begin{array}{l}\text { Ahsanullah University of } \\
\text { Science and Technology }\end{array}$ & 6,552 & 3,846 & 2,706 & 41.3 \\
\hline BRAC University & 10,571 & 7,925 & 2,646 & 25.0 \\
\hline $\begin{array}{l}\text { American International } \\
\text { University-Bangladesh }\end{array}$ & & & \\
\hline \multicolumn{3}{|l|}{ Source: University Grants Commission. Annual Report 2014. } \\
\hline
\end{tabular}

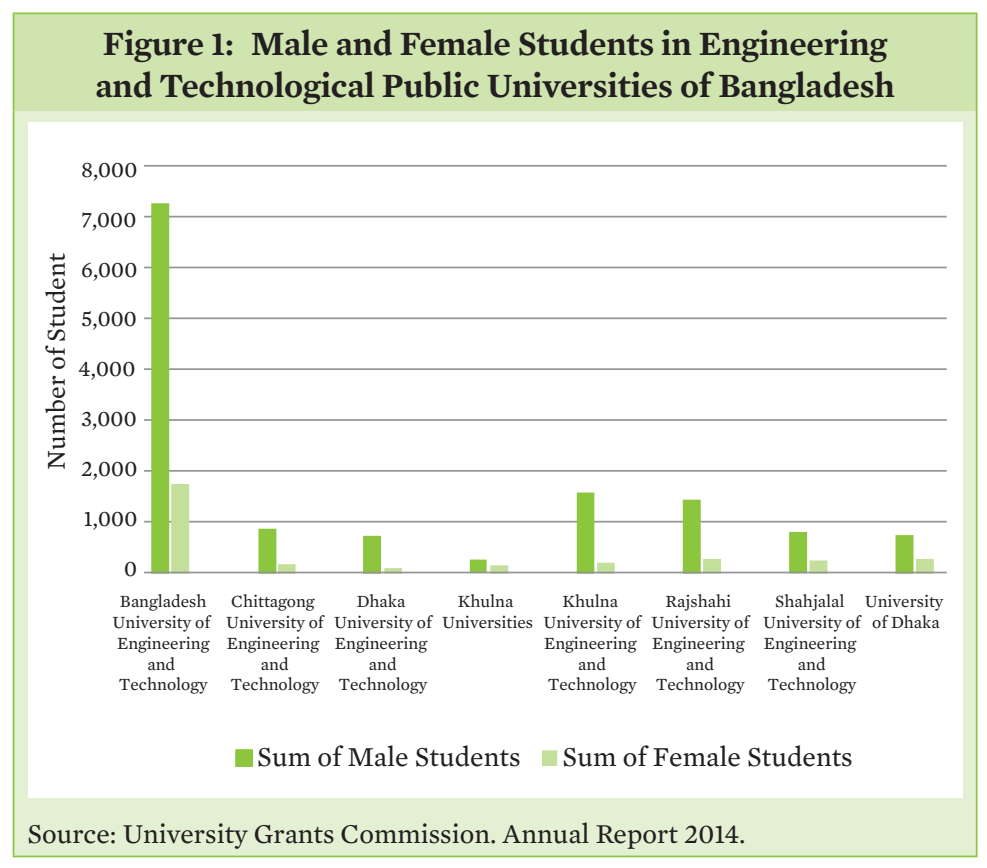

social insecurity mean that women cannot work consistently and cannot gain longterm job benefits. Various efforts are being made to improve their working conditions and reduce wage discrimination.

Due to the lack of skills training, women find it hard to compete with male transport workers. Women from lowincome groups cannot afford the training cost and thus cannot access skilled job opportunities. Women's participation in skilled jobs can be further increased with improved government training assistance.

Public and private transport sector employers have not systematically identified suitable jobs for women. Best practices from other Asian countries where women are employed as drivers in road, rail, water, and air transport can be replicated in Bangladesh. In neighboring countries such as India, Myanmar, and Nepal, it is becoming more common for women to work as operators, supervisors, and managers in toll booths and ticket counters of different types of terminals. There are women in toll booths and petrol pumps in the north of Bangladesh, and the working conditions can be further improved to encourage more women to work in these jobs. According to the bus owners who were consulted for this gender diagnosis, bus terminals in Dhaka City Corporation are safe work areas for women, especially for jobs like ticket counter operation, maintenance, supervision, and auto workshop management.

Enrollment in major technical universities is a prerequisite to encourage women to join the workforce in the transport and infrastructure sector. However, female students are currently less than $30 \%$ of the total in higher tertiary education, and women's enrollment under the Bangladesh Technical Education Board is 6\%. ${ }^{93}$ The current status of enrollment is shown in Table 8 and Figure 1. The board has four women-only institutes in Dhaka, Chittagong, Khulna, and Rajshahi. This indicates a need to encourage and make provision for more girls and women to enroll in technical institutions and gain entry in the formal transport sector.

\footnotetext{
93 Footnote 91
} 


\section{Policy and Institutional Context Relevant for Addressing Gender Inequality}

\section{- National Transport Sector Policies and Their Gender Features}

The Government of Bangladesh passed five policies from 2002 to 2013 (Table 9). While these policies address gender issues, there is scope to further integrate the gender perspective into the policies to ensure effective gender mainstreaming into the transport sector.

National general policies such as the Seventh Five Year Plan, 2016-2020 and the National Women Development Policy 2011 address gender issues in the transport sector. More specifically, the gender strategy section of the Seventh Five Year Plan provides guidelines on how to make the public transport system responsive to the travel needs of women. As stated in Box 6, this includes, among others, (i) providing buses with reserved seats for women or women-only buses during peak period, (ii) increasing bus services for girls' schools and colleges, (iii) making safety and security measures in public transport stations a compulsory part of transport management, and (iv) ensuring road safety. This gender strategy shows the commitment of the government to gender equality and women's empowerment in the transport sector.

The National Women Development Policy 2011 mentions the importance of transportation as part of a genderresponsive work environment. It recognizes that inadequate facilities for childcare, transport, occupational health, and safety discourage women from accessing the job market. It also emphasizes the importance of technical training for women at all levels. This policy specifically states that "Bangladesh has made significant progress towards reducing gender gap, especially in the area of initiative to promote gender-sensitive planning and management of human settlements, especially in urban areas." It also specifies that a Women's Development Training Institute and Training programs at division, district and upazila shall be set up in addition to strengthening the existing Women Development Training Institute in Dhaka. These programs shall impart technical and vocational training and training rights of the women, their education and related awareness. The transport and infrastructure as sectors can set up women development training institute at all levels of administrative boundaries. $^{94}$

Another policy is the Dhaka Structure Plan (2016-2035), which is aimed at improving walkability. Chapter 12 (Enhance the Cityscape with Urban Design and Landscape) seeks to ensure walkability of streets "by improving [the] physical condition and continuity of pedestrian network, integrating green network in required locations." The chapter presents 14 objectives with the ninth objective focusing on ensuring the walkability of Dhaka streets through pedestrian linkages (Box 7). With these policies implemented, women, particularly working women of low-income groups, will benefit significantly as their mobility will increase due to good footpaths, and safe and secure environment.

The institutional structure of the transport sector involves four types of broad subsectors: road, railway, water, and air. Each of these sectors includes different agencies and organizations (Figure 2) overseen by the Ministry of Road Transport and Bridges, Ministry of Railways, Ministry of Inland Waterways, and Ministry of Civil Aviation and Tourism. Various private sector transport operators work alongside these agencies.

\section{- International Policies on Gender in Transportation}

Increased focus on ensuring access to goods and services. There are international transport policies and guidelines that provide useful directions for the transport sector in Bangladesh, especially with regard to gender mainstreaming. At the World Summit on Sustainable Development held in Johannesburg in 2002, member states

\footnotetext{
94 Government of Bangladesh, Rajdhani Unnayan Kartripakkha. 2015. Chapter12: Enhance the Cityscape with Urban Design and Landscape. In Draft Dhaka Structure Plan 2016-2035. Dhaka.
} 
Table 9: National Policies in the Transport Sector

\begin{tabular}{|c|c|c|c|}
\hline Policy & Year & Main Features & $\begin{array}{l}\text { Whether Gender is Addressed } \\
\text { and How }\end{array}$ \\
\hline $\begin{array}{l}\text { National Road Safety } \\
\text { Strategic Action Plan }\end{array}$ & $\begin{array}{c}2002- \\
2004\end{array}$ & $\begin{array}{l}\text { The aim is to reduce road accidents and casualties } \\
\text { through the implementation of adequately } \\
\text { resourced national and local multi-sectoral } \\
\text { plans under the guidance of the National Road } \\
\text { Safety Council. }\end{array}$ & $\begin{array}{l}\text { The road safety policy focuses on } \\
\text { local awareness creation, improving } \\
\text { the quality of life of the poor } \\
\text { without mentioning women. This } \\
\text { can be expanded to include women } \\
\text { and girls. }\end{array}$ \\
\hline $\begin{array}{l}\text { National Land } \\
\text { Transport Policy }\end{array}$ & 2004 & $\begin{array}{l}\text { This is formulated in light of the government's } \\
\text { pledge to establish a transport system that is } \\
\text { safe, cheap, modern, technologically dependable, } \\
\text { environmentally friendly, and acceptable } \\
\text { considering globalization. } \\
\text { - This is prepared with a long term } 30 \text {-year vision } \\
\text { to highlight the role of transport in economic } \\
\text { activities and to support continued economic and } \\
\text { social development. }\end{array}$ & $\begin{array}{l}\text { Future policies have scope to be } \\
\text { more gender sensitive and address } \\
\text { some of issues flagged in this policy. }\end{array}$ \\
\hline $\begin{array}{l}\text { Strategic Transport } \\
\text { Plan for Dhaka }\end{array}$ & 2005 & $\begin{array}{l}\text { This is commissioned by the Dhaka Transport } \\
\text { Coordination Authority and focused } \\
\text { predominantly on developing strategies for } \\
\text { building new infrastructure, including rail } \\
\text { transit, bus rapid transit (BRT), and highway } \\
\text { development. } \\
\text { - The preferred strategy called for short-term } \\
\text { investment in a BRT-based mass transit system } \\
\text { together with the gradual development of a metro } \\
\text { rail system. BRT is a "high-quality bus-based } \\
\text { transit system that delivers fast, comfortable, and } \\
\text { cost-effective services at metro- level capacities } \\
\text { through the provision of dedicated lanes, with } \\
\text { bus ways and iconic stations typically aligned to } \\
\text { the program of the road, off-board fare collection, } \\
\text { and fast and frequent operations. Because BRT } \\
\text { contains features similar to a light rail or metro } \\
\text { system, it is much more reliable, convenient and } \\
\text { faster than regular bus services." } \\
\text { - This encompasses a road management program } \\
\text { that includes the removal of inappropriate road } \\
\text { users such as vendors using road space, and } \\
\text { improvements in the operational practices } \\
\text { of drivers. } \\
\text { - Recommendations of this policy include the } \\
\text { (i) consolidation of the reforms in the bus and } \\
\text { rickshaw industries, (ii) improvement of safety } \\
\text { measures in pedestrian facilities, (iii) institutional } \\
\text { strengthening and capacity building, and } \\
\text { (iv) establishment of a new unitary authority to } \\
\text { integrate land use and transport planning at the } \\
\text { strategic level. }\end{array}$ & $\begin{array}{l}\text { Along with the policy, the BRT } \\
\text { is now being implemented with } \\
\text { gender issues appropriately } \\
\text { addressed through pilot projects } \\
\text { that improve walkability and } \\
\text { safety (e.g., streetlights, dedicated } \\
\text { bus seating for women, reserved } \\
\text { commercial spaces for women at } \\
\text { the BRT stations etc.), and promote } \\
\text { pedestrians' rights. The two Asian } \\
\text { Development Bank-supported } \\
\text { government projects are in two } \\
\text { locations, Uttara in Dhaka North } \\
\text { City Corporation and Gazipur in } \\
\text { Gazipur City Corporation. } \\
\text { The BRT gender strategies may be } \\
\text { applied to all transport projects. }\end{array}$ \\
\hline
\end{tabular}


Table 9 continued

\begin{tabular}{|c|c|c|c|}
\hline Policy & Year & Main Features & $\begin{array}{l}\text { Whether Gender is Addressed } \\
\text { and How }\end{array}$ \\
\hline $\begin{array}{l}\text { Parking Policy } \\
\text { proposed by } \\
\text { Dhaka Transport } \\
\text { Coordination } \\
\text { Authority }\end{array}$ & 2012 & $\begin{array}{l}\text { The overall aims are to outline strategies to } \\
\text { reduce the negative effects of parking and to } \\
\text { provide a guideline for handling the increasing } \\
\text { demand for parking spaces. } \\
\text { - It provides guidelines for appropriate level } \\
\text { of expenditures on, and cost recovery of, the } \\
\text { provision of parking facilities. } \\
\text { - It serves as a framework with which parking } \\
\text { infrastructure and services can be provided and } \\
\text { used efficiently with support of the government } \\
\text { and private sectors, and with which appropriate } \\
\text { institutional arrangements can be created or } \\
\text { strengthened to facilitate effective provision and } \\
\text { management of facilities. }\end{array}$ & $\begin{array}{l}\text { Planned parking spaces can provide } \\
\text { safe jobs to women as managers and } \\
\text { toll collectors. }\end{array}$ \\
\hline $\begin{array}{l}\text { National Integrated } \\
\text { Multimodal } \\
\text { Transport Policy } \\
\text { (Draft) }\end{array}$ & 2013 & $\begin{array}{l}\text { - The major objective is to make the transport } \\
\text { system more affordable, efficient, and } \\
\text { environmentally friendly through reducing } \\
\text { transport cost and creating mechanisms for } \\
\text { reducing accidents. } \\
\text { - The policy is also expected to enhance } \\
\text { competitiveness and help develop service } \\
\text { industries. } \\
\text { - It focuses on the development of roads, rails, } \\
\text { domestic river ports, seaports, as well as on } \\
\text { human resource development that prioritizes rail } \\
\text { and river communication. } \\
\text { - The policy highlights mass transport system } \\
\text { including the urban transport and promotes the } \\
\text { increasing participation of the private sector. } \\
\text { - This policy has a dedicated fund named } \\
\text { "Road Fund." } \\
\text { - Institutional support for the implementation of } \\
\text { this policy was provided by passing the "Road } \\
\text { Fund Board Law 2013." }\end{array}$ & $\begin{array}{l}\text { The policy can play a crucial role in } \\
\text { transportation project planning and } \\
\text { implementation. }\end{array}$ \\
\hline \multicolumn{4}{|c|}{$\begin{array}{l}\text { Institute for Transportation \& Development Policy (ITDP). https://www.itdp.org/library/standards-and-guides/the-bus-rapid-transit- } \\
\text { standard/what-is-brt/ }\end{array}$} \\
\hline
\end{tabular}

agreed to "promote an integrated approach to policy making at the national, regional and local levels for transport services and systems to promote sustainable development, including policies and planning for land use, infrastructure, public transport systems and goods delivery networks, with a view to providing safe, affordable and efficient transportation, increasing energy efficiency, reducing pollution, congestion and adverse health effects and limiting urban sprawl, taking into account national priorities and circumstances," including the needs of women and men. ${ }^{95}$ As a consequence, the focus on transport has shifted away from moving goods and people to ensuring access to goods and services, which better meets the needs of women and men differentially.

\section{Bogotá Declaration on Sustainable Transport Objectives. The 2011 Bogotá} Declaration on Sustainable Transport Objectives, is another international

\footnotetext{
95 Rio+20. 2012. Sustainable, Low Carbon Transport in Emerging and Developing Economics. Rio 2012 Issues Briefs. No. 13. UN Commission on Sustainable Development Secretariat and the Partnership for Sustainable, Low Carbon Transport.
} 


\section{Box 6: Gender Strategy in the Public Transport System}

On promoting the gender responsiveness of the public transport system, the Seventh Five Year Plan (2016-2020) talks about access to support services:

Infrastructure and support services are key to increase women's participation in public spheres. Safe and affordable transport system is necessary to increase women's mobility. The public transport system would be made more frequent, safe and affordable. Public and private transport companies would be encouraged through budgetary incentive to run more buses with reserved seats for women or women only buses during peak period. Employers who employ more women in factories will be provided loan facilities to operate transport services for their women employees. A policy to increase bus services at least for girls' schools and colleges in all cities of the country will be reviewed for implementation. Safety and security (lighting, police patrols, safe toilets, waiting rooms) measures in public transport stations would be a compulsory part of transport management. Road safety can be ensured through enforcement of traffic rules and laws. Cleaning of footpaths, compulsory use of overbridges for road crossing, increased public transports are some other measures to support women's mobility. Training/orientation on the importance of traffic safety would be provided to both public and private service providers using media and also in schools if necessary. Commuter train services between Dhaka and nearby cities, like Narayanganj, Gazipur, Tongi and Narshingdi would be introduced/increased with ladies' compartments at peak hours.

Source: Government of Bangladesh, Planning Commission. 2015. Seventh Five Year Plan FY2016-2020. Dhaka. p. 659.

policy which has influenced the transport sector of Bangladesh, but which does not have an explicit gender dimension. ${ }^{96}$ It states that "the provision of services and infrastructure for the mobility of people and goods is needed for economic and social development, and improved quality of life and competitiveness. These services and transport infrastructure provide secure, reliable, economical, efficient, equitable and affordable access to all, while mitigating the negative impacts on health and the environment locally and globally, in the short, medium and long term, without compromising the development of future generations.”

The World Summit on Sustainable Development transportation development paradigm and the sustainable transport objectives of the 2011 Bogotá Declaration are reflected in the "avoid-shift-improve" (ASI) approach, which was developed with the objective of promoting alternative mobility solutions and developing sustainable transport systems. ${ }^{97}$ The approach entails three main avenues:

1. Avoid. Avoid the need for unnecessary travel by providing improved

\footnotetext{
${ }_{96}$ Foro de Transporte Sostenible para Américan Latina. 2011. Bogota Declaration: Sustainable Transport Objectives. The representatives of Argentina, Brazil, Bolivia, Chile, Colombia, Ecuador, Mexico, Paraguay, and Uruguay gathered in June 2011.

97 GIZ. n.d. Sustainable Urban Transport: Avoid-ShiftImprove $(A-S-I)$.
}

access to goods and services (by constructing more markets, health facilities, schools, and other key facilities near the homes of people; allowing home-based work; using telecommunication; integrating public transit into land use and urban planning; and others).

2. Shift. Shift to transport-efficient modes, such as bus rapid transit (BRT), public bike schemes, rail-based mass transit, and pedestrianization, which benefit the poor and women.

3. Improve. Improve existing forms of transport through technological improvements to make engines and fuels less carbon intensive; through inspection and maintenance programs to reduce local pollution, which affects women and children more; and through Global Plan for the Decade of Action for Road Safety 2011-2020, which is now an official UN campaign.

Since the World Summit on Sustainable Development in 2002 and the Bogotá Declaration in 2011, promising approaches to integrate gender considerations in the transport system and promote sustainable transport have been developed. As mentioned, one of these is the ASI approach, which offers a more sustainable alternative to unrestrained private motorization. This approach and the greater emphasis 
on mass public transportation have led to socially and gender-responsive transport initiatives, such as the Greater Dhaka Sustainable Urban Transport Project. The ASI approach has influenced the formulation of transport projects and programs of Road Transport and Highways Division and LGED. Development partners have also emphasized the need to target the abovementioned major three objectives in their funding of rural and urban programs in Bangladesh.

The gender strategies for the transport sector of the Seventh Five Year Plan and of the recently drafted Dhaka Structure Plan 2016-2035, which are presented in the previous section, are also aligned with the SDGs mentioned above.

\section{Overall Good Practices and Lessons}

Implementing the avoid-shift-improve approach for gender responsiveness. Greater Dhaka Sustainable Urban Transport Project is an ongoing project of the construction of a 20-km BRT corridor, sidewalks, one NMT lane along the BRT, and terminal facilities. This project aims to develop a sustainable urban transport system in Gazipur City Corporation, which forms part of north Greater Dhaka. ${ }^{98}$ This pilot project, which is expected to be operational by 2020 , incorporates transport safety design features for women, children, and the disabled, including the development of sidewalks and dedicated bus seating for women, and will have reserved commercial spaces at BRT stations for women vendors. The design of the BRT was based on a study on BRT walkability strategy done by the Work for a Better Bangladesh Trust in Dhaka. The recommendations of this study are listed in Box 8. This is still limited to Dhaka.

Making women and girls more mobile. An initiative to make women and girls more mobile is providing them with bicycles,

\footnotetext{
98 ADB. 2012. Report and Recommendation of the President to the Board of Directors: Proposed Loans and Technical Assistance Grant, and Administration of Loan and Grant to the People's Republic of Bangladesh for the Greater Dhaka Sustainable Urban Transport Project. Manila.
}

Box 7: Draft Dhaka Structure Plan 2016-2035: Objective-UD 09 (Pedestrian Linkages): Ensuring Walkability in Urban Streets

1. Policy-UD/9.1: Develop and Maintain Sidewalks in UserFriendly Way to Ensure Walkability

Strategic Actions

- Standardizing sidewalks for different types of streets based on their hierarchy and demand

- Adopting the policy by city corporations and municipalities in developing sidewalks

Implementation Tools

- Executing the policy during design and construction of streets sidewalks

- Enforcing law to evict the unauthorized uses of sidewalks to ensure walkability

Implementing Agencies

- Ministry of Local Government, Rural Development and Cooperatives, Local Government Engineering Department, city corporations and municipalities, Rajdhani Unnayan Kartripakkha (RAJUK), Roads and Highways Department

2. Policy-UD/9.2: Designate and Implement Pedestrian-Friendly Legible Street Networks and Green Pedestrian Networks in Continuation

Strategic Action

- Developing existing sidewalks and new sidewalks in userfriendly manner within the city centers, major activity nodes, and areas surrounding transit nodes (this is particularly relevant for women pedestrians, providing them a safe and secure walking environment for livelihoods and social and family reasons)

Implementation Tool

- Taking up project to redevelop existing sidewalks and green pedestrian networks in user-friendly way

- City corporations and municipalities, RAJUK, Roads and Highways Department

3. Policy-UD/9.3: Ensure Amenity and Safety of Handicapped and Elderly Pedestrians

Strategic Action

- Developing standards to develop sidewalks

Implementation Tool

- Taking up project to redevelop existing sidewalks and new sidewalks

Implementing Agencies

- City corporations and municipalities, RAJUK, Roads and Highways Department

Source: Government of Bangladesh, RAJUK. 2015. Dhaka Structure Plan 2016-2035. Dhaka.

scooters, or motorcycles. Some private banks are providing students with loans to buy bicycles to go to school or college and providing women with loans to buy scooters. Some development projects have provided their female field staff with motorcycles to 


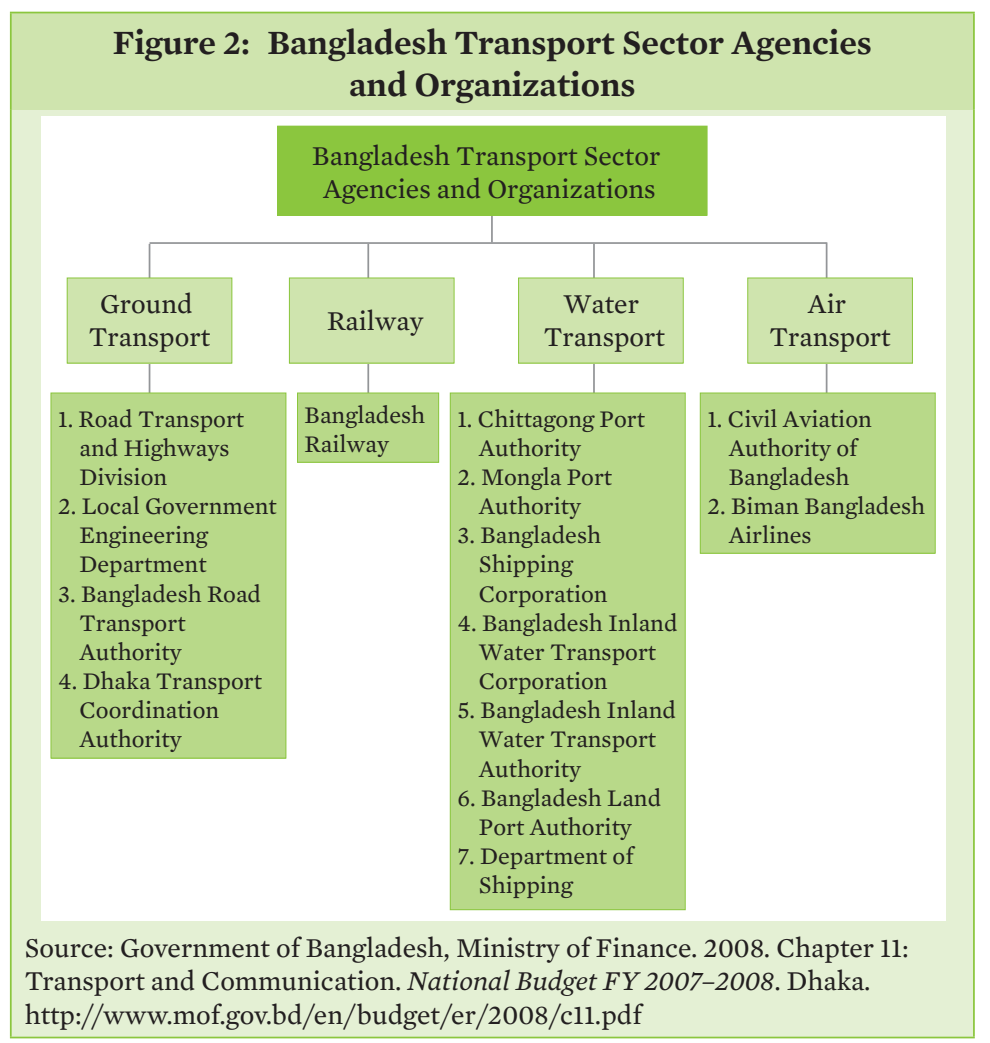

carry out their work, and its use has been mandatory. This practice, which dates to the 80 s, has contributed to making women's presence and mobility in the public sphere more common and acceptable.

Community Road Safety Project of the Building Resources Across Communities. A good practice is the adoption of community policing to promote road safety awareness and practices particularly to benefit women and children. ${ }^{99}$ Community policing is described by the Bangladesh Police as a national philosophy and strategy that "allows the police and community to work closely together in new ways to solve the problems of crime, fear of crime, physical and social disorder and neighborhood decay."100 In addition, the community activities for road safety benefit women passengers, particularly in the safety and security aspects of mobility. In adopting community policing, the intervention shows that this can be applied to road safety too. To do this, community road safety groups are organized

\section{Box 8: Bus Rapid Transit Walkability Strategy: Moving Dangerously, Moving Pleasurably}

In a study of bus rapid transit (BRT) walkability strategy, the Work for a Better Bangladesh (WBB) Trust put forward the following recommendations to improve the walkability of Shahjalal Avenue, Uttara, Dhaka:

(i) To accommodate pedestrians, ensure an unobstructed footpath width of 3 meters.

(ii) To reduce conflicts between pedestrians and vehicle users, use bicycle lanes as buffers, extend sidewalk widths at intersections, and raise well-used intersections to the level of footpaths.

(iii) To eliminate mobility barriers for pedestrians with physical disabilities, construct level footpaths, ensure crosswalks are raised (or, where this is impractical, cut curbs at intersections with wheelchair-friendly slopes (1:12 rise-run ratio), and retrofit existing car entry/exit cuts to accommodate wheelchairs.

(iv) To increase shade cover and protection from precipitation, plant trees (preferably fruit bearing, broad-leaved varieties) at 6-meter intervals along footpaths' outside edge and between vendors at the bazaar near the BRT corridor, plant banyan trees at gathering places, and erect planted trellis shades above bicycle parking and rickshaw stands.

The study also proposed the following:

(i) Improvement of rickshaws. This mode provides employment to a large section of the urban poor population. Rickshaws serve as an easy mode of transport for the low and middle-income groups. It poses as a solution to transportation needs of women, children, the elderly, and the disabled.

(ii) Promotion of bicycle use and training in bicycle riding. WBB Trust recommends the inclusion of bicycle lanes in all Asian Development Bank (ADB) transport projects for both urban and rural areas.

(iii) Provision of service roads along major highways and busy roads. This is to ensure safety for women who are frequent victims of road accidents.

Source: ADB. 2012. Sustainable Urban Transport: Dhaka Bus Rapid Transit Walkability Strategy. Consultant's report. Manila (TA 6350).

99 BRAC. Road Safety. http://www.brac.net/road-safety

100 Government of Bangladesh, Bangladesh Police. 2014. Community Policing: National Strategy for Bangladesh. www.nipsa.in/uploads/country_ resources_file/1014_Community_Policing_ National_Strategy.pdf 
and their capacity in road safety activities are developed. The responsibilities of the community road safety groups are to (i) keep the bus stand free of traffic congestion, (ii) assist passengers in getting in and out of the vehicles, (iii) help pedestrians in crossing the roads, and (iv) control irregular parking of vehicles along side roads. Their other activities are collecting money from the community to paint missing marks of a speed breaker, requesting LGED to install a shed at local bus bay, and advocating vendors to stop encroaching the road with their stalls. They also give post-accident support to victims of road casualties by helping them get medical treatment immediately after the accident and receive financial compensation. They also conduct infotainment or theater shows in the communities to raise awareness on road safety. Majority of the audience are women and children.

Increasing safety for women through SafetiPin. Another road safety measure applied in Bangladesh, particularly Dhaka, in June-July 2015 is the women safety audit using SafetiPin, ${ }^{101}$ which is a mapbased mobile phone application initiated in India. It seeks to make communities and cities safer by providing safetyrelated information collected by users and by trained auditors. The safety audit measures a set of nine parameters that together contribute to the perception of safety. These are (i) lighting in the area, (ii) openness of the area, (iii) visibility in the area, (iv) people density, (v) security, (vi) walk path, (vii) transportation in the area, (viii) gender diversity in the area, and (ix) feeling. Each audit results in a pin on the specific location where the audit was performed and records the time and date. Women in distress due to lack of road safety or harassment in the public place can seek help through the SafetiPin.

International practices facilitating access. It is also important to mention good practices in other South Asian countries (e.g., India and Nepal) on improving walkability through sidewalks, benches and others. Other good practices involve the use of women as bus conductors and ticket collectors, and separate bus doors for women. The Bangladesh Road Transport

\footnotetext{
${ }^{101}$ SafetiPin. http://safetipin.com/about/theApp
}

Corporation had tried to employ women bus conductors, but could not continue due to lack of social acceptability.

In Latin America, Mexico City leads the way in improving public transportation infrastructure. One of the first cities to designate women-only entrances and subway compartments during rush hour, the city also launched the Athena program (women-only buses) in 2008. Currently, there are 67 Athena buses covering 23 of the 91 routes across the city. Easily identified by large letters in pink saying, "Exclusive Service for Women," these buses run from 6 a.m. to 9 p.m. Pregnant women, elderly people, and those with disabilities travel free. ${ }^{102}$ This example shows that improving the public transport system from the viewpoint of women's safety does not require overly complicated or expensive solutions. What it does need is political will, a long-term vision, and sustained efforts, which combine improvements in infrastructure and services with sensitization, and capacity building.

Application of government policies and guidelines on gender equity to the private sector through public-private partnership. The adoption of publicprivate partnerships (PPP) in developing the transport sector is another promising approach recognized by the Seventh Five Year Plan (Box 9).

The following examples are private sector projects where the guidelines of the gender policy and the Seventh Five Year Plan are being followed.

An initiative by the private sector serving to customers of buses, trains and launches is Shohoz.com, a premium online travel service provider owned by Shohoj. It is aimed to make long-distance travel in Bangladesh easy and convenient. They have pioneered the online travel industry service of offering bus tickets, hotel reservations, and launch tickets. In general, buying tickets at the ticket counter is time-consuming, with people having to travel to the ticket

\footnotetext{
${ }^{102}$ Special Media Features on Women, Safety, and the City, Women Feature's Service, Global WOMEN ONLY: FROM DELHI TO MEXICO, MAKING PUBLIC TRANSPORT SAFER By Shipra Narang Suri, Pg 2. http://www.safedelhi.in/sites/default/ files/reports/WFS\%20Articles\%20_1.pdf
} 


\section{Box 9: Public-Private Partnership in Public Transportation Development}

At present, the private sector is involved in the transport sector through ownership and management of buses, taxis, baby taxis, ferries, and rickshaws that are used for public transport. The Seventh Five Year Plan supports this involvement of the private sector, as this lessens government responsibility of providing transport services to the growing number of population and reduces government expenditures on transport. To promote public-private partnership (PPP) in transport development, the plan discusses role of public and private sectors.

Both public and private actors have an important role to play in the provision of transportation. While it is necessary to encourage investment and partnership with private sector for infrastructure development, there should be efforts for increasing and ensuring employment, following labor standards and equity within PPP initiatives. The PPP contract conditions can be laid in advance with provisions for construction and management along with possible women's employment in road construction (share of work, ensuring equal wages for work of equal value, childcare, insurance etc.), transportation services (such as driving, ticketing, security). Equality of wages for women and men, and transport service designs to address women's needs as users and employees should be incorporated in all the contract conditions and monitored.

Source: Government of Bangladesh, Planning Commission. Sector 6 Transport \& Communication. In Seventh Five Year Plan FY2016-2020. Dhaka. pp. 387-400.

\begin{tabular}{|l|c|c|c|c|c|}
\hline \multicolumn{5}{|c|}{$\begin{array}{c}\text { Table 10: Bangladesh Transport Projects } \\
\text { by ADB Gender Category }\end{array}$} \\
\hline Year Approved & GEN & EGM & SGE & NGE & Total \\
\hline $2009-2012$ & 1 & 1 & 5 & & 7 \\
\hline $2013-2015$ & 2 & 1 & 1 & 2 & 6 \\
\hline Total & 3 & 2 & 6 & 2 & 13 \\
\hline $\begin{array}{l}\text { ADB = Asian Development Bank, EGM = effective gender mainstreaming, GEN } \\
\text { gender equity theme, NGE = no gender elements, SGE = some gender elements. } \\
\text { Source: South Asia Department Gender and Development Database 2016. }\end{array}$ \\
\hline
\end{tabular}

counters and stand in line, uncertain about whether they would be able to get tickets. Also, there is a practice of selling tickets on the black market, especially during peak periods. By putting customers in touch with the transport agencies, the middle persons are eliminated. Through such companies, women do not have to be dependent on others to get their tickets or have to face the inconvenience of purchasing them in person. ${ }^{103}$ The company has been set up by professionals in e-commerce and internet product development.

${ }^{103}$ Shohoz.com. https://www.shohoz.com/about-us
Hiring women to sell tickets at bus counters has recently been started by a special bus service run by HR Transport Agency in Hatirjheel Area, Dhaka. Out of 16 people working at the counters, eight are women. However, the media reports that the women have difficulties due to the lack of toilets and security. ${ }^{104} \mathrm{~A}$ more sustained initiative by the private sector is the provision of male and female stations as well as small snacks shops in all petrol pumps on all major roads, especially outside the cities.

\section{Gender Equality and Transport: the ADB Experience}

The transport sector accounts for the second largest number of $\mathrm{ADB}$ loan and TA projects in Bangladesh (after agriculture, natural resources, and rural development). The total number of ADB-funded transport projects in Bangladesh and their gender classifications (Box 5) are shown in Table 10. This section briefly reviews the gender strategies of some of these transport projects to be able to draw lessons from those.

\section{- Gender Features of Selected ADB-Assisted Projects}

Preparation of gender action plans. The ADB-assisted transport projects have some features that are common with projects in the urban development sector. This includes the preparation of gender action plans (GAPs), which are resourced and monitored, and have specific actions and outputs. In the case of the GEN loan project Sustainable Rural Infrastructure Improvement Project (SRIIP), a TA project Support to Local Government Engineering Department in Institutionalizing Women's Benefits from Rural Infrastructure Initiatives helped develop the GAP for the SRIIP. ${ }^{105}$ The resulting GAP of the project identified four key areas for facilitating women empowerment:

(i) Employment of the poor women in construction works by labor

\footnotetext{
${ }^{104}$ M. Chiran. 2016. Girls Break a Social Barrier. The Daily Star. 9 October.

105 ADB. 2010. Support to Local Government Engineering Department in Institutionalizing Women's Benefits from Rural Infrastructure Initiatives. Manila (Project 40515-022-BAN).
} 
contracting societies (LCS)

and contractors.

(ii) Employment of the poor women in road maintenance and tree plantation activities.

(iii) Skills development training for female shop owners, LCS members, and laborers in improved rural market infrastructure.

(iv) Better knowledge, tools, and genderrelated performance criteria used by LGED.

The details of component outputs of the GAP are provided in Table 11.

The implementation of GAPs also has their challenges, especially in the case of large complex projects. The experience of the Greater Dhaka Sustainable Urban Transport Project is that there is a need to include GAPs for every component in the case of projects as large and complex as this. Another lesson is that the establishment of a mechanism such as a gender cell (a specialized unit in the project or department) can further enhance the implementation and monitoring of the GAP.

Gender focal structure. Apart from preparing GAPs, the LGED has assigned an institutional structure-the Gender and Development Forum-that is tasked to strengthen gender mainstreaming in their projects. This structure facilitates crosslearning across projects and spearheads the implementation of the LGED's Gender Equality Strategy.

Gender mainstreaming capacity development for executing and implementing agencies. The transport projects of LGED provide capacity building to government agencies and local government bodies such as in the municipalities covered by the second and third Urban Governance and Infrastructure Improvement Project (UGIIP-II and UGIIP-III) and the union parishads covered by SRIIP.

Use of performance-based approach. UGIIP-II, UGIIP-III, and SRIIP use performance-based approach that has proven to be effective to improve the participation of women in local structures and processes. The TA project of $\mathrm{ADB}$ to

\begin{tabular}{|c|c|c|}
\hline \multicolumn{3}{|c|}{$\begin{array}{c}\text { Table 11: Gender Action Plan: Sustainable Rural } \\
\text { Infrastructure Improvement Project }\end{array}$} \\
\hline $\begin{array}{l}\text { Sector } \\
\text { Components }\end{array}$ & $\begin{array}{l}\text { Activities, Indicators, } \\
\text { and Targets }\end{array}$ & Cumulative Progress \\
\hline \multirow[t]{9}{*}{$\begin{array}{l}\text { Improved } \\
\text { rural roads }\end{array}$} & $\begin{array}{l}\text { Women's participation } \\
\text { in consultation on } \\
\text { infrastructure planning } \\
\text { and implementation }\end{array}$ & $\begin{array}{l}\text { Women participation } \\
\text { ensured in consultation } \\
\text { of infrastructure } \\
\text { planning (only for } \\
\text { awarded roads) }\end{array}$ \\
\hline & $\begin{array}{l}\text { Women's employment } \\
\text { (30\% of the estimated } \\
28,500 \text { person-years } \\
\text { of jobs created) as } \\
\text { laborers in labor } \\
\text { contracting societies } \\
\text { (LCS), earthworks, and } \\
\text { construction of roads } \\
\text { and markets }\end{array}$ & $\begin{array}{l}\text { Laborers employed } \\
\text { in } 122 \text { upazilas in } 21 \\
\text { districts for earth road } \\
\text { improvement work } \\
\text { (31.80\% women) }\end{array}$ \\
\hline & $\begin{array}{l}\text { 1,200 women in tree } \\
\text { plantation and road } \\
\text { maintenance through } \\
\text { LCS }\end{array}$ & $\begin{array}{l}155 \text { women as caretakers } \\
\text { for tree plantation } \\
\text { in } 38 \text { roads under } \\
12 \text { districts }\end{array}$ \\
\hline & $\begin{array}{l}\text { Pay equal wage for } \\
\text { women and men }\end{array}$ & \\
\hline & $\begin{array}{l}\text { Train 1,200 LCS women } \\
\text { on routine maintenance, } \\
\text { tree caretaking, etc. }\end{array}$ & \\
\hline & $\begin{array}{l}\text { Train 1,200 LCS women } \\
\text { on various income- } \\
\text { generating activities }\end{array}$ & $\begin{array}{l}\text { 20\% women within } \\
\text { various levels of } \\
\text { Sustainable Rural } \\
\text { Infrastructure } \\
\text { Improvement Project } \\
\text { (SRIIP) employment }\end{array}$ \\
\hline & $\begin{array}{l}\text { Require savings and } \\
\text { open bank accounts for } \\
\text { 1,200 LCS women }\end{array}$ & $\begin{array}{l}\text { - } 118 \text { LCS women opened } \\
\text { bank account in } \\
12 \text { districts }\end{array}$ \\
\hline & $\begin{array}{l}\text { Employ poor indigenous } \\
\text { women living in the } \\
\text { project area }\end{array}$ & $\begin{array}{l}\text { 1,344 poor indigenous } \\
\text { women employed at } \\
9 \text { districts of project area }\end{array}$ \\
\hline & $\begin{array}{l}\text { Include women in the } \\
\text { markets in the road } \\
\text { safety orientation }\end{array}$ & $\begin{array}{l}\text { Road safety awareness } \\
\text { program outsourced to } \\
\text { a local firm } 6 \text { batches } \\
\text { of participant lists } \\
\text { completed for } \\
\text { participatory training } \\
\text { on gender, market, and } \\
\text { road safety }\end{array}$ \\
\hline $\begin{array}{l}\text { Improved } \\
\text { rural market } \\
\text { infrastructure }\end{array}$ & $\begin{array}{l}\text { Construct and allocate } \\
\text { about } 500 \text { shops in } 50 \\
\text { growth center markets } \\
\text { for women traders } \\
\text { (allocate } 1-2 \text { shops to } \\
\text { indigenous women, } \\
\text { if available in the } \\
\text { project area) }\end{array}$ & $\begin{array}{l}\text { - Shops allotted to } \\
\text { women as shop owners } \\
\text { in markets include } \\
\text { indigenous women } \\
\text { - Women vendors allotted } \\
\text { space in open markets }\end{array}$ \\
\hline
\end{tabular}

continued on next page 
Table 11 continued

\begin{tabular}{|c|c|c|}
\hline $\begin{array}{l}\text { Sector } \\
\text { Components }\end{array}$ & $\begin{array}{l}\text { Activities, Indicators, } \\
\text { and Targets }\end{array}$ & Cumulative Progress \\
\hline & $\begin{array}{l}\text { Train } 500 \text { shop owners } \\
\text { on business skills, shop } \\
\text { management, market } \\
\text { management committee } \\
\text { function, and link them } \\
\text { with traders' association }\end{array}$ & \\
\hline & $\begin{array}{l}\text { Earmark and allocate } 15 \% \\
\text { space for women vendors } \\
\text { in open sheds to be } \\
\text { developed in } 92 \text { growth } \\
\text { center markets }\end{array}$ & \\
\hline & $\begin{array}{l}\text { Orient market } \\
\text { management committee } \\
\text { and traders to support } \\
\text { female shop owners and } \\
\text { women vendors and to } \\
\text { include them as members } \\
\text { of traders' associations }\end{array}$ & \\
\hline & $\begin{array}{l}\text { Provide support } \\
\text { including separate toilets } \\
\text { and safe water supply for } \\
\text { women in the markets }\end{array}$ & \\
\hline & $\begin{array}{l}\text { Provide solar energy and } \\
\text { piped water supply in } \\
\text { pilot markets }\end{array}$ & \\
\hline & $\begin{array}{l}\text { Provide need-based } \\
\text { training to } 100 \text { female } \\
\text { shop owners }\end{array}$ & \\
\hline
\end{tabular}

the Government of Bangladesh-Support to Local GovernmentEngineering Department in Institutionalizing Women's Benefits from Rural Infrastructure Initiativesexplored the potentials of applying the performance-based approaches of LGED in facilitating women's participation in the union parishads (local government institutions). One of the objectives was to help LGED pilot a performance-based approach to improve women's participation in local governments and union parishad structures and processes. The anticipated impact of the project is an enhancement of women's participation in local governance and the local economy. Such performancebased approaches provide an incentive for local government bodies to address gender equity concerns.

Setting targets for women's employment and participation. The Greater Dhaka Sustainable Urban Transport Project has a target of $20 \%$ female staff to be employed in the special project organization. The SRIIP and the Second Chittagong Hill Tracts Rural Development Project targeted 30\% women laborers and in the labor contracting societies (LCS) both for construction and maintenance, while putting in safeguards to ensure decent working conditions and equal wages. The GEN-categorized Second Chittagong Hill Tracts Rural Development Project (CHTRDP-II) prioritizes the project-affected people, particularly destitute women, in construction employment. ${ }^{106}$ The targets are to recruit at least $20 \%$ women for the union and upazila level construction employment; $100 \%$ women rural maintenance workers and preference will be given to interested destitute women for the hauling of construction materials. Both projects seek to ensure poor indigenous women are included. SRIIP includes the provision that the women employed through the LCS should have bank accounts and compulsory savings. Some of the constraints identified in the CHTRDP-II Project are the feeling of discomfort of indigenous women in working with supervisors from other cultures and lower payment for women compared with their male counterparts in the LCS groups. Lessons include the need for further study to identify better approaches to increasing women's participation in skills training, and the need to consider cultural differences and ethnic factors in the formulation of genderspecific project objectives. And most recently, the Greater Dhaka Sustainable Urban Transport Project specifies that 20\% of the staff to be recruited in the special project organization should be women.

Involving women in rural markets. SRIIP is providing training on business skills and shop management, and orientation to market management committees to support women. CHTRDP-II Project makes provisions for including women in decision-making positions in market management committees and reserves 50\% of market space for women sellers. Project achievements include the integration of the

\footnotetext{
${ }^{106}$ ADB. 2011. Second Chittagong Hill Tracts Rural Development Project. Manila (Project 42248-013BAN).
} 
needs of indigenous people in the project design, and participation of community groups including women. These are examples of proactive measures taken to overcome prevalent social barriers to women's access to markets, especially as sellers and entrepreneurs. This approach is not new to either LGED or ADB, and it is tried and tested as providing positive benefits to women.

Although not in rural areas, the Greater Dhaka Sustainable Urban Transport Project also plans to reserve at least $15 \%$ of the commercial spaces at BRT stations for women vendors.

Ensuring women's benefits from transport projects. The railways project (South Asia Subregional Economic Cooperation Railway Connectivity: Akhaura-Laksam Double Track Project) and the Greater Dhaka Sustainable Urban Transportation Project both give special emphasis to women as passengers and take various measures to ensure their use of the transportation, and their safety and comfort. ${ }^{107}$ The latter project aims at delivering a $20-\mathrm{km}$ BRT corridor. Part of its targets is to ensure that at least $70 \%$ of garment workers (the majority of whom are women) using BRT receive subsidized monthly travel passes; that $50 \%$ of students (60\% should be female) receive subsidized BRT monthly passes; and that $20 \%$ of the staff to be recruited in the special project organization are females. ${ }^{108}$ It also seeks to reserve $20 \%$ of bus seats for women with young children, pregnant women, children, the elderly, and the handicapped; to enforce availability of reserved seats; and to ensure separate queuing system for male and female passengers at BRT stations with priority boarding for pregnant women, the elderly, children, and the handicapped.

In the railway sector, among the targeted outputs of the EGM-categorized South Asia Subregional Economic Cooperation Railway Connectivity: Akhaura-Laksam Double Track Project is the rehabilitation

\footnotetext{
107 ADB. 2015. South Asia Subregional Economic Cooperation Railway Connectivity: Akhaura-Laksam Double Track Project. Manila (Project 46168-001BAN).

108 Footnote 98 (Greater Dhaka Sustainable Urban Transport).
}

of 11 railway stations to be equipped with separate toilets and ablution and prayer facilities for male and female passengers, and lighted waiting rooms and disabilityfriendly access features. Bangladesh Railway residential buildings are to include separate dormitories and facilities for men and women. Increasing the public's awareness on the improvements of Bangladesh Railway and motivating clients to use this transport mode can further enhance gender equality results in the project.

Attaching technical assistance projects to loan projects for greater opportunity to achieve gender equality and women's empowerment results. Gender equality and women's empowerment considerations are integrated and pursued in some ADBsupported transport projects through TA projects such as the Support to Local Government Engineering Department in Institutionalizing Women's Benefits from Rural Infrastructure Initiatives. This was attached to a GEN-categorized loan project, Sustainable Rural Infrastructure Improvement Project. The provision of such TA is also to test out and introduce practices which can promote gender equality.

Strengthening safety and security aspects of transport. A lesson is that the safety and security aspects of transport for users, particularly women and children, need to be strengthened and brought into public knowledge and cognizance by planners, implementers, and monitors. This was realized in the railway sector, in the project South Asia Subregional Economic Cooperation Railway Connectivity: Akhaura-Laksam Double Track Project. The Greater Dhaka Sustainable Urban Transport Project also addresses women's safety and security in various ways.

\section{Strengthening Gender Equality Approaches}

This section outlines the possible actions to strengthen gender equality approaches in the transport sector. Annex 1 provides a tip sheet on integrating gender perspectives in transport projects. Annex 2 provides a list of useful resource materials. 


\section{Policy Development}

A. Review and amend existing policies to ensure women's representation in the transport sector and to integrate gender considerations (e.g., different transportation-mobility and accessibility-needs and interests of women and men).

B. Formulate policies for pedestrian mobility (especially women's safety) during road and bridge construction and maintenance at the national and local government levels.

\section{Institutional Capacity Development of Government Agencies}

C. Increase women's participation and representation in transport sector institutions, e.g., associations, boards, committees of both private and public transport sector organizations.

D. Develop the competencies of government transport agencies and private sector transport operators and associations in mainstreaming gender in transport development and management.
Government of Bangladesh (Ministry of Commerce, Ministry of Railways, Bangladesh Inland Water Transport Authority, Ministry of Civil Aviation and Tourism)

Government of Bangladesh, donors, nongovernment organizations (NGOs)

Government of Bangladesh (Ministry of Commerce, Ministry of Railways, Bangladesh Inland Water Transport Authority, Ministry of Civil Aviation and Tourism), private sector transport associations

Private sector transport associations; government agencies such as Ministry of Commerce, Ministry of Railways, Bangladesh Inland Water Transport Authority, Ministry of Civil Aviation and Tourism, Ministry of Planning

\section{Building Partnerships between the Government and the Private Sector}

E. Do oversight and monitoring of private service providers to encourage and ensure (i) employment of women and provision of equal wage for work of equal value and type to women and men transport workers in compliance with labor standards, and (ii) attention to the differing needs and interests of women and men as users of transport services.

\section{Research and Evaluation}

F. Conduct continuous research and monitoring to assess the changing transport (mobility and accessibility) needs of women and men, and how transport service providers are addressing these needs. Pay attention to the needs of women in small towns, security of women in urban and rural areas (including road safety), and women's employment.

\section{Project Planning and Design}

G. Traffic planners and transport project designers must listen to the voices of women users and ensure that transport infrastructures (road, rail, and water) are responsive to their distinct needs.

H. Include civil society organizations (NGOs, transport associations, community organizations) during transport project formulation to address needs of special groups such as children, women, the elderly, and people with disabilities.

I. Ensure safe outdoor spaces with standard streetlighting and sanitation facilities in public places, and climate-resilient and disability-sensitive infrastructure design. Safety and security definitions should be broadened to include physical safety (e.g., not being injured in any type of traffic accident) as well as freedom from fear of sexual violence and harassment.

\section{Project Implementation and Evaluation}

J. Provide women with employment opportunities in project implementation (e.g., construction) and in the management of transport facilities and services.

K. Improve the access of girls and women to technical schools and training institutions to enable them to assume technical and supervisory roles in the transport sector, through quotas, providing scholarships, and training teachers and trainers in gender sensitivity.
Ministry of Road Transport and Bridges, Bangladesh Inland Water Transport Authority, private sector associations

Government of Bangladesh, donors, NGOs, consultants, contractors

Government of Bangladesh, donors, NGOs, community-based organizations

Planning Commission, NGOs, Transport

Owners Association

Government of Bangladesh, donors, NGOs and community-based organizations

Ministry of Road Transport and Bridges, Roads and Highways Department, Inland Water Transport Authority, railways

Directorate of Secondary and Higher Education; Ministry of Labour and Employment; Bureau of Manpower, Employment and Training 


\section{Annex 1: Tip Sheet on Questions and Design Features for Gender Mainstreaming in Transport Projects}

\section{Illustrative outcomes of projects and related possible gender equality outcomes \\ Increased connectivity \\ - Increased women's mobility \\ - Increased accessibility of transport through reduced travel time to reach social services (health facilities, schools, government welfare programs, etc.) for women \\ - Increased access to markets and employment for women \\ - Increased affordability of transport services to women of poor households \\ - Increased access even in conditions of bad weather and natural disasters}

Examples of questions to consider in analyses to formulate project strategies and gender-related design features

- What are the usual travel destinations of women, compared with those of men?

- How long does it usually take rural and urban women to reach these destinations? How about men?

- What are the common reasons for the less accessibility of these destinations for women? For men? How does this vary by income groups?

- What travel destination needs, both urban and rural, do most transport projects address? Which travel needs are mostly addressed-men's, women's, or both?

- Is the cost of transport services affordable to women of poor households?

- Are transport agencies aware of the different travel needs of women and men? Do they have an established system for collecting sex-disaggregated travel data?

- Are there policies that will oblige them to do so? Are there guidelines or manuals on how to prepare gender-responsive transport plans, programs, and projects? Are they trained to do this? Do they have a staff or officer assigned to ensure this?
Examples of possible gender- related design features, measures, and activities that might be relevant (or adaptable)

- Conduct consultations (preferably separate consultations with women and with men) to determine their usual travel destinations and state of transport infrastructures and services to these destinations.

- Conduct a gender assessment of transport agencies and transport projects.

- Review and enhance the gender responsiveness of transport policies, master plans, and implementation arrangements (including of the organizational setup and capacity of transport agencies).

- Establish or enhance genderresponsive transport data management system.

- Provide training on gender sensitivity and gender mainstreaming in transport development.

- Develop guides or manuals on how to mainstream gender in transport development.

- Ensure that transport plans and projects consider the differing travel destinations of women and men; plan routes of multimodal transport utilities in consideration of the differing travel needs of women and men.

- Address priorities for safety and security of women and girls, and needs of the disadvantaged groupsthe elderly, women with children, and people with disabilities.

- Ensure that the transport fare schemes are affordable for women of poor households. 


\section{Illustrative outcomes of projects and related possible gender equality outcomes \\ Improved road safety and transport security}

- Increased sense of personal security and dignity in women's use of public transport

\section{Examples of questions to consider in analyses to formulate project strategies and gender-related design features}

- Are transport designs (roads, railways, ports, etc.) sensitive to the travel safety and security needs of women? Are there sidewalks (strictly for use of pedestrians), footpaths, ramps, adequate streetlights, safe bike lanes, terminal stations with separate toilets for women and girls, lighted parking areas, road signage?

- Is the condition of roads safe for pregnant women, the elderly, and persons with disabilities?

- Are there emergency means of communicating and monitoring problems (phone booths, closedcircuit television, etc.)

- What is the usual transport or mobility mode used by women and men? Do buses and trains have reserved seats for women, the elderly, and persons with disabilities?

- Are there ways of monitoring safety issues and travel at night?

\section{- What are the barriers to women's} entry into transport agencies and association, and in transportrelated careers?

- Decreased gap in the proportion of women and men in transport sector

- Increased social acceptability of women's employment in the transport sector
- How many women (compared with men) are there in transport agencies and associations (government and private)?

- How many females (compared with males) have academic degrees related to transport development? How many females (compared with males) are currently enrolled in academic and vocational courses related to transport?

- What are the steps needed to promote women's employment in operation, maintenance, and supervisory positions?
Examples of possible gender- related design features, measures, and activities that might be relevant (or adaptable)

- Develop standards and guides for gender-sensitive transport infrastructure (roads, railways, ports, etc.) designs and public vehicles; and make compliance mandatory by policy.

- Conduct public awareness campaigns on the importance of gender-sensitive transport infrastructures (during designing construction and maintenance).

- Mobilize community participation (with both women and men in ensuring compliance of transport infrastructure projects with gendersensitive standards during designing, construction, and maintenance.

- Orient and test drivers on gendersensitive code of conduct for drivers.

- Develop a monitoring and evaluation system to continually assess the gender aspects of transportation infrastructures.

- Provide training to transport agencies on gender-sensitive transport infrastructures, and organize lateral learning visits to learn from others

- Develop educational or skills development programs that promote and support the entry of girls and women to careers and jobs related to transport development.

- Adopt measures to proactively identify and employ interested and qualified women in the transport project-field or road construction, office staff work, and others.

- Adopt a quota system for women staff and workers in the transport project. 


\begin{tabular}{|c|c|c|}
\hline $\begin{array}{l}\text { Illustrative outcomes of projects } \\
\text { and related possible gender } \\
\text { equality outcomes }\end{array}$ & $\begin{array}{l}\text { Examples of questions to consider } \\
\text { in analyses to formulate project } \\
\text { strategies and gender-related } \\
\text { design features }\end{array}$ & $\begin{array}{l}\text { Examples of possible gender- related } \\
\text { design features, measures, and } \\
\text { activities that might be relevant } \\
\text { (or adaptable) }\end{array}$ \\
\hline $\begin{array}{l}\text { - Increased number of women-led } \\
\text { transport-related enterprises } \\
\text { - Increased participation of women as } \\
\text { transport operators and owners }\end{array}$ & $\begin{array}{l}\text { What are transport-related } \\
\text { enterprises? How many women } \\
\text { entrepreneurs (compared with men) } \\
\text { are involved in these? } \\
\text { - What is the nature of the value chain } \\
\text { of the transport industries? What } \\
\text { is the proportion of women to men } \\
\text { involved in each phase of the value } \\
\text { and supply chain? What are the } \\
\text { possible entry points of women in } \\
\text { the value and supply chain? } \\
\text { - What are the facilitators and barriers } \\
\text { to women's entry in each phase of } \\
\text { the value and supply chain of the } \\
\text { transport industry? } \\
\text { - What interventions are needed to } \\
\text { increase and strengthen women's } \\
\text { participation in each phase of } \\
\text { the value and supply chain of the } \\
\text { transport industry? }\end{array}$ & $\begin{array}{l}\text { - Conduct a gender-responsive value } \\
\text { and supply chain analysis of the } \\
\text { transport industry and identify } \\
\text { possible entry points of women } \\
\text { based on the results. } \\
\text { - Provide transport-related enterprise } \\
\text { development skills and services } \\
\text { (including access to finance) to } \\
\text { interested women (actual and } \\
\text { potential entrepreneurs). } \\
\text { - Reserve commercial spaces in } \\
\text { terminal stations (bus, train, } \\
\text { pier, airport, etc.) for women } \\
\text { entrepreneurs. } \\
\text { - Provide finances to enable women to } \\
\text { become entrepreneurs in private run } \\
\text { motorized and vehicle business. } \\
\text { - Expose female students and women } \\
\text { to model women entrepreneurs in } \\
\text { the transport sector (develop videos } \\
\text { and case studies on these women). }\end{array}$ \\
\hline $\begin{array}{l}\text { Active representation and participation } \\
\text { of women in transport decision- } \\
\text { making bodies }\end{array}$ & $\begin{array}{l}\text { What transport bodies (structures } \\
\text { or groups) make decisions on } \\
\text { the design features and manner } \\
\text { of implementation of transport } \\
\text { infrastructure projects? What is } \\
\text { the proportion of women to men in } \\
\text { these transport bodies? } \\
\text { - What is the proportion of women to } \\
\text { men in community road safety groups? }\end{array}$ & $\begin{array}{l}\text { Adopt a quota system for women } \\
\text { representatives in transport } \\
\text { decision-making bodies and } \\
\text { community road safety groups. } \\
\text { - Conduct leadership training } \\
\text { program for women in the transport } \\
\text { sector and female students in } \\
\text { transport-related courses. }\end{array}$ \\
\hline $\begin{array}{l}\text { Established safeguards for } \\
\text { women affected by transport } \\
\text { infrastructure projects }\end{array}$ & $\begin{array}{l}\text { What policies, mechanisms, and } \\
\text { procedures are in place to ensure } \\
\text { that adverse effects of transport } \\
\text { infrastructure projects on women are } \\
\text { identified and adequately addressed? } \\
\text { - Are the designers and implementers } \\
\text { aware and capable of executing these } \\
\text { safeguards policies, mechanisms, and } \\
\text { procedures? } \\
\text { - How are safeguards frameworks or } \\
\text { plans (resettlement framework } \\
\text { or plan, livelihood restoration } \\
\text { framework or plan, hazards and } \\
\text { illness prevention framework or } \\
\text { plan, school disturbance prevention } \\
\text { framework or plan) formulated, } \\
\text { implemented, monitored, and } \\
\text { implemented? } \\
\text { - How do affected women participate } \\
\text { in the development, implementation, } \\
\text { monitoring, and evaluation of } \\
\text { safeguards plans? }\end{array}$ & $\begin{array}{l}\text { - Conduct public or community } \\
\text { awareness campaign on the social } \\
\text { safeguards policies of transport } \\
\text { infrastructure projects and on } \\
\text { safeguards framework or plan of } \\
\text { a project. } \\
\text { - Conduct consultations on the } \\
\text { potential effects of transport } \\
\text { projects; ensure the participation } \\
\text { of both women and men in } \\
\text { these consultations. } \\
\text { - Ensure that the project safeguards- } \\
\text { related frameworks and plans } \\
\text { equitably and adequately respond to } \\
\text { the specific conditions and needs of } \\
\text { women and men. } \\
\text { Ensure that the grievance resolution } \\
\text { mechanism is sensitive to the } \\
\text { conditions of women and men } \\
\text { and involve both women and men; } \\
\text { ensure that voices of women and } \\
\text { other marginalized groups are heard. }\end{array}$ \\
\hline
\end{tabular}


Annex 1 continued

\begin{tabular}{|c|c|c|}
\hline $\begin{array}{l}\text { Illustrative outcomes of projects } \\
\text { and related possible gender } \\
\text { equality outcomes }\end{array}$ & $\begin{array}{l}\text { Examples of questions to consider } \\
\text { in analyses to formulate project } \\
\text { strategies and gender-related } \\
\text { design features }\end{array}$ & $\begin{array}{l}\text { Examples of possible gender- related } \\
\text { design features, measures, and } \\
\text { activities that might be relevant } \\
\text { (or adaptable) }\end{array}$ \\
\hline & $\begin{array}{l}\text { What are considered in the } \\
\text { establishment of grievance } \\
\text { resolution mechanisms? What is } \\
\text { the participation of project-affected } \\
\text { women and men in the designing, } \\
\text { implementation, monitoring, and } \\
\text { evaluation of these mechanisms? }\end{array}$ & \\
\hline $\begin{array}{l}\text { Strong civil society participation } \\
\text { (with both women and men at the } \\
\text { frontline) in transport development } \\
\text { and management }\end{array}$ & $\begin{array}{l}\text { What policies and mechanisms are } \\
\text { in place to facilitate the participation } \\
\text { of the communities and community- } \\
\text { based organizations (including } \\
\text { women) in transport sector } \\
\text { development and management } \\
\text { (including road safety)? } \\
\text { - Who implements these mechanisms? } \\
\text { What is the participation of } \\
\text { nongovernment organizations } \\
\text { (NGOs)? } \\
\text { - What are the beliefs and practices } \\
\text { of the communities with regard to } \\
\text { women's participation in community } \\
\text { initiatives related to transport } \\
\text { development and management? } \\
\text { What capacity development } \\
\text { (orientation, values transformation, } \\
\text { skills, etc.) do men and women need } \\
\text { to enable women's participation in } \\
\text { these community initiatives? }\end{array}$ & $\begin{array}{l}\text { - Formulate policies, programs, } \\
\text { and mechanisms for gender- } \\
\text { responsive community participation } \\
\text { in transport development and } \\
\text { management (including road safety). } \\
\text { - Engage NGOs in mobilizing } \\
\text { community (including women's) } \\
\text { participation. } \\
\text { - Promote gender awareness and } \\
\text { sensitivity in the communities. } \\
\text { - Train women to participate in } \\
\text { community initiatives for transport } \\
\text { development and management. } \\
\text { - Develop videos and case studies } \\
\text { on model community participation } \\
\text { in transport development and } \\
\text { management. }\end{array}$ \\
\hline
\end{tabular}




\section{Annex 2: Useful Resources for Further Reading on Gender Equality in Transport}

\begin{tabular}{|c|c|}
\hline $\begin{array}{l}\text { Bangladesh-specific research } \\
\text { and analyses on gender and } \\
\text { transportation }\end{array}$ & $\begin{array}{l}\text { - Government of Bangladesh, Planning Commission. 2015. (Final Draft) Gender Equality } \\
\text { and Women's Empowerment: Suggested Strategies for the Bangladesh Seventh Five Year } \\
\text { Plan (2016-2020). Dhaka. } \\
\text { - Government of Bangladesh, Ministry of Local Government, Rural Development and } \\
\text { Cooperatives. 2011. National Urban Sector Policy (Draft). Dhaka. } \\
\text { - S.A. Shafi. 2004. Spatial Growth of Dhaka, Metropolis: Transportation Needs and the } \\
\text { Rickshawas an important Mode of Transport. Bimonthly Magazine on Public Services, } \\
\text { Development \& Administration. Good Governance India. 1(4). Sep-Oct. } \\
\text { - S.A. Shafi. 2000. Urban Crime and Violence in Dhaka. Dhaka: The University Press } \\
\text { Limited. } \\
\text { - M.K. Shefali. 2000. Study on Gender Dimension in Dhaka Urban Transport Project. } \\
\text { - S.C. Zohir. 2003. Integrating Gender into World Bank Financed Transport Programs: } \\
\text { Case Study-Bangladesh Dhaka Urban Transport Project. Washington, DC: World Bank. } \\
\text { http://documents.worldbank.org/curated/en/451771468206959040/Integrating- } \\
\text { gender-into-World-Bank-financed-transport-programs-case-study-Bangladesh-Dhaka- } \\
\text { Urban-Transport-Project }\end{array}$ \\
\hline $\begin{array}{l}\text { Other research and analyses articles } \\
\text { on gender and transportation }\end{array}$ & $\begin{array}{l}\text { - C. Duchène. 2011. Gender and Transport. International Transport Forum Discussion } \\
\text { Paper. No. 2011-11. http://www.itf-oecd.org/sites/default/files/docs/dp201111.pdf } \\
\text { - K. Kusakabe. 2009. Gender Mainstreaming in Transport Sector in ADB. Slides } \\
\text { summarizing a paper presented at Technical Session on Gender Mainstreaming } \\
\text { in Infrastructure Projects, 10th Session of the External Forum on Gender and } \\
\text { Development. Overview of issues with lessons learned and recommendations. } \\
\text { - D. Peters. 2001. Gender and Transport in Less Developed Countries: A Background } \\
\text { Paper in Preparation for CSD-9. Background paper for the Expert Workshop, Gender } \\
\text { Perspectives for Earth Summit 2002: Energy, Transport, Information for Decision- } \\
\text { Making. www.earthsummit2002.org/workshop/Gender\%20\&\%20Transport\%20S\%20 } \\
\text { DP.pdf } \\
\text { - D. Peters. 2011. Gender and Sustainable Urban Mobility. Prepared for the Global Report } \\
\text { on Human Settlements 2013. Provides a gender perspective on various forms of urban } \\
\text { transport (non-motorized, public, informal, commercial goods) as well as on transport } \\
\text { planning and policy approaches): http://www.toronto.ca/legdocs/mmis/2012/cc/bgrd/ } \\
\text { CC20_1_app3_24.pdf } \\
\text { - J. Babinard. 2011. World Bank Gender Transport Surveys: An Overview. World Bank } \\
\text { Transport Notes. TRN-43. September. go.worldbank.org/O5I149H4G0 } \\
\text { - University of Copenhagen. 2007. Gender Mainstreaming European Transport Research } \\
\text { and Policies, Building the Knowledge Base and Mapping Good Practices, Co-ordination for } \\
\text { Gender Studies. } \\
\text { - M.S. Haque et al. 2007. Impact of Garment Industries on Road Safety in Metropolitan } \\
\text { Dhaka. Proceeding of the Eastern Asia Society for transportation Studies. Vol. 6. } \\
\text { www.adb.org/publications/project-gender-action-plans-lessons-achieving-gender- } \\
\text { equality-andpoverty-reduction-res?ref=themes/gender/publications } \\
\text { - ADB. 2013. Gender mainstreaming strategy enhancing gender equality results in Asian } \\
\text { Development Bank. Manila. } \\
\text { - Further resources and guides on gender action plans: www.adb.org/themes/gender/ } \\
\text { project-action-plans }\end{array}$ \\
\hline
\end{tabular}

Bangladesh-specific research and analyses on gender and transportation

Other research and analyses articles on gender and transportation
- Government of Bangladesh, Planning Commission. 2015. (Final Draft) Gender Equality and Women's Empowerment: Suggested Strategies for the Bangladesh Seventh Five Year

Government of Bangladesh, Ministry of Local Government, Rural Development and Development \& Administration. Good Governance India. 1(4). Sep-Oct.

S.A. Shafi. 2000. Urban Crime and Violence in Dhaka. Dhaka: The University Press Limited.

S.C. Zohir. 2003. Integrating Gender into World Bank Financed Transport Programs: Case Study-Bangladesh Dhaka Urban Transport Project. Washington, DC: World Bank (1/documents.worldbank.org/curated/en/451771468206959040/Integratinggender-into-World-Bank-financed-transport-programs-case-study-Bangladesh-Dhaka-

Paper. No. 2011-11. http://www.itf-oecd.org/sites/default/files/docs/dp201111.pdf

K. Kusakabe. 2009. Gender Mainstreaming in Transport Sector in ADB. Slide in Infrastructure Projects, 10th Session of the External Forum on Gender and Development. Overview of issues with lessons learned and recommendations. Paper in Preparation for CSD-9. Background paper for the Expert Workshop, Gende Perspectives for Earth Summit 2002: Energy, Transport, Information for DecisionMaking. www.earthsummit2002.org/workshop/Gender\%20\&\%20Transport\%20S\%20 transport (non-motorized, public, informal, commercial goods) as well as on transport planning and policy approaches): http://www.toronto.ca/legdocs/mmis/2012/cc/bgrd/

J. Babinard. 2011. World Bank Gender Transport Surveys: An Overview. World Bank and Policies, Building the Knowledge Base and Mapping Good Practices, Co-ordination for Dhaka. Proceeding of the Eastern Asia Society for transportation Studies. Vol. 6. www.adb.org/publications/project-gender-action-plans-lessons-achieving-gender-

Further resources and guides on gender action plans: www.adb.org/themes/gender/ 


\section{Energy Sector}

\section{Summary}

Although one of the government's highest priorities is providing electricity and other commercial energy to the population for rapid overall economic growth, at the household level, especially in the rural areas, affordable clean energy remains scarce and inaccessible to many. About $76 \%$ of the population of Bangladesh has access to electricity as of June 2016. ${ }^{109}$ Biomass fuels remain the main source of cooking energy in the country, but these have various negative consequences. Renewable energy resources are available and can potentially enable greater and more equitable access. Energy is critical to women's empowerment and development because access to clean and affordable energy services is a precondition for improved women's health, children's better ability to study, and women's greater livelihood opportunities. With inadequate access to energy, women's domestic responsibilities are more burdensome. The women together with their daughters and other female members in charge of household chores are more at risk of health complications from using biomass for cooking. It is globally recognized that energy in the form of lighting contributes to education and livelihoods as well as to safety and security in the public space, especially for women. The development of energy infrastructure may, however, have unintended negative effects on livelihood and income generation of families, especially women, if the necessary safeguards are not in place.

To gear energy development toward responding to women's empowerment and development needs, it is important for

\footnotetext{
109 Power Division. Bangladesh's Power Sector at a Glance (accessed on 18 October 2017) http://www.powerdivision.gov.bd/ site/page/6cd25d49-3150-482a-8bd0701d18136af7/\%E0\%A6\%8F\%E0\%A6\%95-\%E0\%A 6\%A8\%Е0\%A6\%9C\%Е0\%А6\%В0\%Е0\%A7\%87
}

energy programs and projects to proactively adopt gender mainstreaming strategies. Unfortunately, although the government is committed to empowering women and achieving gender equality as reflected in its national policies and being a signatory to international gender-related agreements, there is still room for improvement for government agencies responsible for power generation and distribution, including promotion of renewable energy and energy efficiency to to mainstream gender into its programs and activities.

There are several good practices and lessons in mainstreaming gender equality in the energy sector. The Bangladesh Rural Electrification Board (BREB) has conducted gender analysis, and corresponding gender strategies have been formulated. ${ }^{110}$ Women technicians have been involved in renewable energy initiatives. Women's involvement in the Community Biogas Project of the Rural Development Academy (RDA) is a promising initiative. International development partners engaged in the energy sector of Bangladesh have also taken steps toward gender mainstreaming in their programs and projects. With its increasing commitment to achieving gender equality and women's empowerment, ADB is taking steps to ensure mainstreaming gender in its energy programs and projects. Nonetheless some challenges remain. The energy sector has been traditionally male dominated with technical and engineering education and jobs considered to be unsuitable for women. There is a lack of women at senior levels who can bring in a gender perspective to decision-making. Professionals and managers in the sector are not aware of how their ideas and information for new initiatives and projects, including those elements that relate to gender issues, could be addressed. The final section of

\footnotetext{
110 J. Clancy et al. 2003. Comprehensive Gender Strategy and Action Plan for Integration in REB Master Plan. ENERGIA.
} 
this chapter outlines the possible actions to strengthen gender equality approaches in energy sector development. Annex 1 provides a tip sheet on integrating gender perspectives in energy development. Annex 2 provides a list of useful resource materials.

\section{Sector Context}

The energy sector of Bangladesh mainly consists of electricity, gas, coal, oil, and renewable energy. The main focus of the government is to ensure energy security for the country in the short and long term by developing power generation capacity and ensuring supply of primary fuel such as oil, gas, and coal. The comprehensive 'Power System Master Plan (PSMP) 2016' has been produced for the attainment of stable power supply up to 2041, taking into consideration the need for diversification of fuel resources. The key strategies are (i) enhancement of imported energy infrastructure and its flexible operation; (ii) efficient development and utilization of domestic natural resources (gas and coal); (iii) construction of a robust, high-quality power network; (iv) maximization of green energy and promotion of its introduction; and (v) improvement of human resources and mechanisms related to the stable supply of energy.

Developing renewable energy and improving energy efficiency in all sectors of the economy are also given priority as part of the government's commitment to reducing and mitigating effects of climate change. At the user level, the main energy priorities and concerns of the government are to provide electricity and motive power to the industrial, commercial, irrigation, and household consumers.

There has been a concerted effort to improve the production and distribution of electricity. The government has adopted a reform program to increase the supply of electricity involving substantial investment, sector reforms, and regional trade. The implementation review done in preparation of the Seventh Five Year Plan revealed that there was a $133 \%$ increase in the expansion of installed power generation capacity up to FY2015 over the baseline
FY2010. ${ }^{111}$ The population's access to electricity increased from the FY2010 baseline of $48 \%$ to $72 \%$ in FY2015. ${ }^{112}$ The per capita electricity consumption also increased from 220 kilowatt-hour to 371 kilowatt-hour. Overall, these numbers suggest an impressive performance in electricity production, distribution, and consumption during the Sixth Five Year Plan period. About $76 \%$ of the population of Bangladesh has access to electricity as of June 2016, with a total of 21.8 million connections. $^{113}$ According to other sources (the World Bank and ADB), the electrification rate was $90 \%$ in urban areas and $42 \%$ in rural areas in 2014 (Figure 1). The majority of electricity is supplied through gas-powered thermal generation (67.98\%). ${ }^{114}$ Rental power producers using diesel, furnace oil, and gas generators have been contracted to meet peak demand in the summer. ${ }^{115}$ Bangladesh has been importing electricity from India since September 2013. The single hydropower generation facility in Kaptai is the primary grid-connected renewable energy source of power.

There are 14 government, autonomous, and semiautonomous organizations operating in power and energy sector, and all operate under the overall leadership of Ministry of Power, Energy and Mineral Resources (MPEMR). Out of those, seven are involved in electricity generation, one in transmission, and six in distribution. MPEMR and its related agencies are governed by 14 policy documents and 9 acts, starting from Electricity Act of 1910 to Bangladesh Rural Electrification Board Act 2015.116

\footnotetext{
${ }^{111}$ Second Five Year Plan FY2015-FY2020; Slide 19 https://www.google.com/url?sa=t\&rct=j\&q=\&e src $=$ s\&source $=$ web\&cd=3\&ved $=0$ ahUKEwiMx7 Pd2_nWAhVKMZoKHfGEAIAQFggwMAI\&url= http\%3A\%2F\%2Fird.portal.gov.bd\%2Fsites\%2F default\%2Ffiles\%2Ffiles\%2Fird.portal.gov.bd\%2 Fnotices\%2Fe1675bb0_7fef_4e99_8999_1f3c33da 74cd\%2FBANGLADESH\%2520SEVENTH\%252 OFIVE\%2520YEAR\%2520PLAN\%2520-FINAL. pptx\&usg=AOvVaw0OsafOXRcNhu_HZcUvk4PO

112 Footnote 109 (Power Division).

${ }^{113}$ Footnote 109 (Power Division).

114 Bangladesh Power Development Board Annual Report, 2014-2015. pp. 12-13.

115 Rental power producers are medium-scale private sector suppliers that own and operate about 2121 MW generation capacity.

116 Power Cell. Policy. http://www.powercell.gov.bd/ site/page/df8df070-9518-480c-bd53-eala24d0a783/ Policy
} 

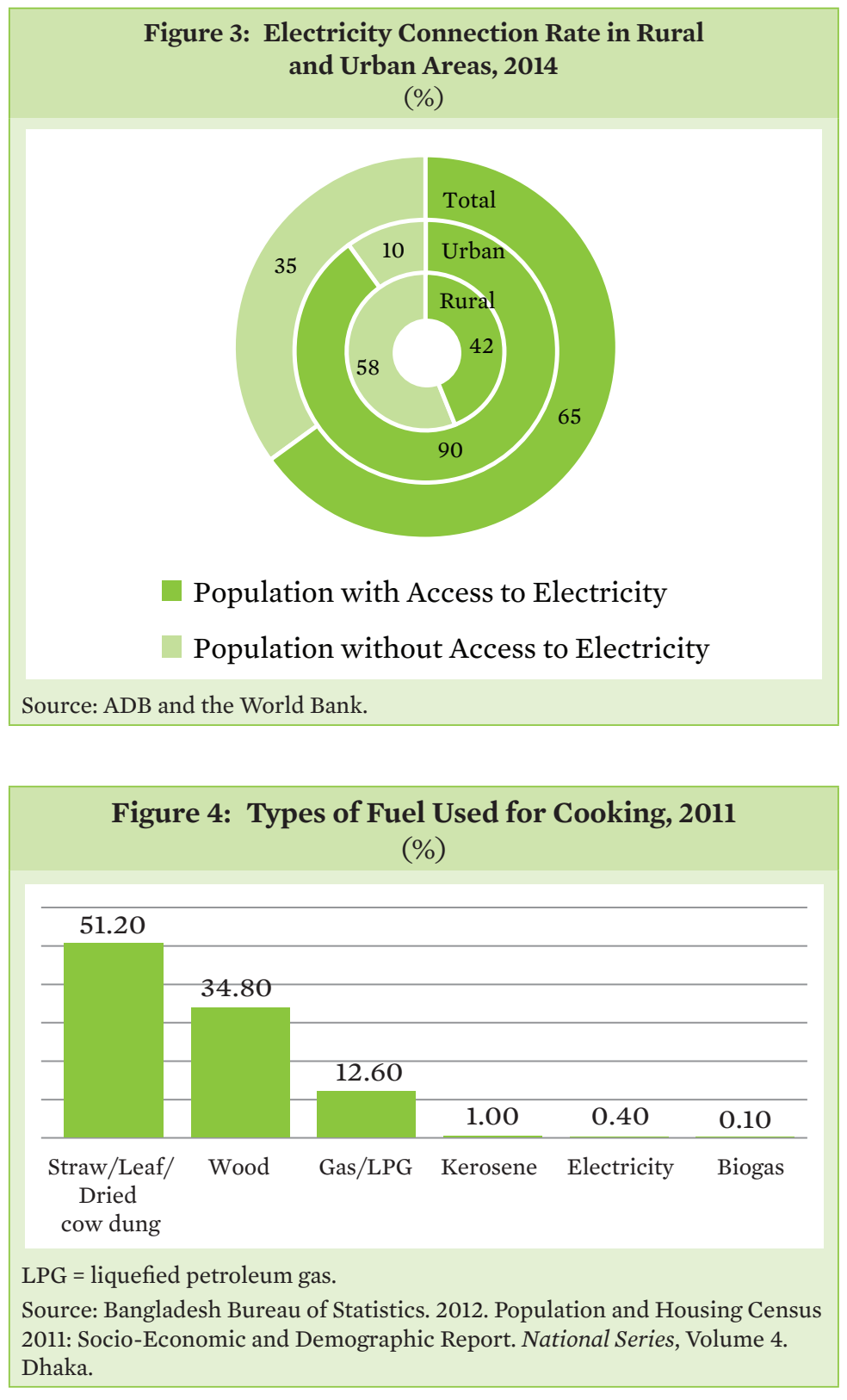

Table 12: Trends in Use of Cooking Fuel over Time (\%)

\begin{tabular}{|l|c|c|}
\hline Fuel Type & $\mathbf{2 0 1 1}$ & $\mathbf{2 0 0 4}$ \\
\hline Wood & 34.8 & 31.76 \\
\hline Kerosene & 1.0 & 1.79 \\
\hline Gas/liquefied petroleum gas & 12.6 & 9.09 \\
\hline Electricity & 0.4 & 0.76 \\
\hline Straw/Leaf/Dried cow dung & 51.1 & 55.91 \\
\hline Bio-gas & 0.1 & - \\
\hline $\begin{array}{l}\text { Source: Government of Bangladesh, Bangladesh Bureau of Statistics. 2012. } \\
\text { Socio-Economic and Demographic Report. National Series, Volume 4. Dhaka. } \\
\text { p. 10. }\end{array}$ \\
\hline
\end{tabular}

Figure 3 shows the electricity connection rate $^{117}$ in rural ${ }^{118}$ and urban areas. ${ }^{119}$ The main use of electricity in the residential sector is for lighting, fans, television, and mobile charging. Use of other appliances like iron, rice cookers, refrigerators, computers, music programs, etc., is more prevalent in the urban areas, but is also gaining popularity in more affluent rural households because of convenience of use and exposure to modern lifestyle. In addition to household use, electricity is one of the main sources of energy for productive and commercial activities.

Although one of the government's highest priorities is providing electricity and other commercial energy to the population for rapid overall economic growth at the household level, especially in the rural areas, affordable clean energy remains scarce and inaccessible to many.

In the rural areas, the primary source of energy for cooking is biomass fuels. Although Bangladesh is urbanizing rapidly, it is still primarily a rural country with $72 \%$ of the population living in rural areas. ${ }^{120}$ Biomass fuels remain the main source of cooking energy for households and commercial consumers in the rural areas. The contribution of biomass to total energy consumption in 2013 was about $27 \%$ of around 33,900 kilo tons of oil equivalent (ktoe). ${ }^{121}$ The share of different types of fuel used for cooking is provided in Figure $4 .{ }^{122}$ Consumption pattern of biomass fuels has seen changes in recent years-the percentage of total residential consumption decreased from $81 \%$ to $70 \%$ between 2000

117 ADB. 2013. Bangladesh: Increasing Access to Energy. Manila.

118 World Bank. 2014. US \$600 Million to Improve Electricity Supply in Rural Bangladesh Benefitting 25 Million People. Press release. 27 February

119 World Bank. Access to electricity (\% of population). http://data.worldbank.org/indicator/EG.ELC .ACCS.ZS

120 Government of Bangladesh, Bangladesh Bureau of Statistics. 2012. Population and Housing Census 2011: Socio-Economic and Demographic Report. National Series, Volume 4. Dhaka.

${ }^{121}$ World Bank. Data bank : World Development Indicators. http://databank.worldbank.org/data/ reports.aspx? source=2\&country=BGD (accessed 30 June 2017)

${ }^{122}$ Government of Bangladesh, Bangladesh Bureau of Statistics. Socio-Economic and Demographic Report 2012. Dhaka. pp. xi-xii. 
and 2012 (Table 12). ${ }^{123}$ This has been due to expansion of natural gas connections and availability of liquefied petroleum gas (LPG) cylinders in the urban areas.

Use of biomass fuel has costs in terms of time needed and negative health impacts. Biomass fuels consist of wood, leaves, dung, grass, peat, and agricultural residues. Most of rural and peri-urban women spend a large share of their time collecting biomass and cooking with it. Those who can afford it purchase firewood, but most of them use it in inefficient traditional fixed clay stoves. The use of hazardous cooking fuels in badly ventilated places contributes to over 49,000 premature deaths per year in Bangladesh, caused by indoor air pollution. Women, who tend to be primarily responsible for cooking, and the children are the most affected. ${ }^{124}$ For the vast majority of households, increasing efficiency of the biomass burning cookstoves is a desired outcome that will impact the health of millions of women users and eliminate the other negative effects of traditional and inefficient cooking practices. Improved cookstoves should ensure fuel efficiency, safety, reduced emissions, affordability, durability, and convenience for household cooking needs.

Piped gas and liquefied petroleum gas are safer and healthier alternatives for cooking energy. In some of the larger cities, adjacent townships, and peri-urban areas, piped natural gas connection is available at subsidized price. ${ }^{125}$ There are more than 3 million household gas connections in the country supplied by four natural gas transmission and distribution companies. ${ }^{126}$ However, this is not accessible everywhere. Because of increasing shortage of indigenous gas, most LPG is being imported and distributed in two or three sizes of cylinders for household use. This is, however, very

\footnotetext{
${ }^{123}$ Scaling Up Renewable Energy Program for Bangladesh (SREP Bangladesh); https://www.iea. org/policiesandmeasures/pams/bangladesh/name157149-en.php

${ }^{124}$ UNICEF. 2014. Improving the lives of children while cutting carbon emissions: Spotlight on Bangladesh.

125 Domestic gas tariff is Tk650 per month for unlimited use of a two-burner stove used in most households.

${ }^{126}$ Petrobangla. http://petrobangla.org.bd/?params=en/ distribution
}

expensive compared with natural gas, not affordable for most households, and not available everywhere in the country. ${ }^{127}$ Despite having higher costs than piped gas, improving the distribution network of LPG will allow many households to use this convenient fuel for cooking.

Renewable energy resources are more available and can potentially enable greater and more equitable access. Bangladesh has considerable renewable energy resources in the form of solar photovoltaic energy, solar thermal energy, and biogas. Application of renewable energy and energy efficiency initiatives, especially for cooking, lighting, and productive activities will greatly benefit women's lives. Solar technology is convenient, proven, and well accepted in Bangladesh. Considerable amount of solar irradiation is available throughout the year in all parts of the country. According to Sustainable and Renewable Energy Development Authority (SREDA), total generation based on solar energy is 185.27 megawatts (MW). ${ }^{128}$ This includes 4.4 million solar home systems installed up to April 2016 in off-grid areas all over the country. ${ }^{129}$ Solar pumping systems are increasingly being used for irrigation and drinking water supply to a certain extent. Other uses of solar energy are also being introduced by Infrastructure Development Company Limited (IDCOL) and others. ${ }^{130}$ Solar thermal is a technology that has large potential but is yet to be popularized.

Potential of economicallyharvestablewind resource on shore is being investigated through ongoing wind mapping projects. As the potential of wind energy is mainly limited to coastal areas and offshore islands, there have been limited investments in the absence of adequate data. The only two operating government projects are the 900 kilowatts grid-connected plant in Muhuri Dam and the 1,000 kilowatt windbattery hybrid power plant at Kutubdia

\footnotetext{
127 Monthly expenditure of LPG can vary from Tk1,200 to Tk5,000 or more depending on use or size of family.

128 SREDA. http://www.sreda.gov.bd/index.php/site/ re_present_status (accessed 1 November 2016).

129 Infrastructure Development Company Limited (IDCOL). http://idcol.org/home/solar

130 Footnote 109 (Powercell Policy).
} 
Island. ${ }^{131}$ However, the level of generation from the plants is not optimal.

Biogas technology is being promoted by different organizations. Bangladesh Council of Scientific and Industrial Research, Local Government Engineering Department (LGED), IDCOL, Rural Development Academy (RDA), Grameen Shakti, and others have been promoting biogas technology for a long time. ${ }^{132}$ Biogas is the mixture of different gases produced by the breakdown of organic matter; typically, biogas is produced from raw materials such as agricultural waste, manure, municipal waste, plant material, sewage, green waste, or food waste. Biogas plants not only provide gas for cooking purpose but also produce organic fertilizer for the crops and fish ponds. IDCOL has a target to install 100,000 biogas plants for use in household levels for supplying cooking fuel. This technology is also highly relevant for the involvement of women as both users and service providers.

\section{Key Gender Issues in the Sector}

Energy shortage has differential impacts on women, and it is a critical constraints on economic development and the quality of life for women in both urban and rural areas. Although poverty reduction and energy access have a direct linkage to each other, most of the time, poverty reduction and gender-related projects do not take this into consideration and the linkages with women's development and empowerment are not made. Since women have an important role to play in energy systems through their subsistence and productive tasks, they are also most affected by energy poverty.

Energy projects are treated as genderneutral, based on the assumption that energy impacts men and women in similar ways. In most countries, this does not reflect reality and has led to "gender-blind"

\footnotetext{
${ }^{131}$ Bangladesh Power Development Board (BPDB). Development of Renewable Energy Technologies by BPDB. http://www.bpdb.gov.bd/bpdb/index .php?option $=$ com_content $\&$ view $=$ article $\&$ id $=26 \&$ Itemid $=24$

132 A nonprofit village renewable energy scheme, linked to the microcredit lender, Grameen Bank, pioneering solar systems for homes in Bangladesh.
}

projects, which in some cases have not been successful due to the failure to consider the distinct situations of women and men in relation to energy production and use patterns. In addition, decisions concerning technical and other aspects of projects often only consider male views.

In this section, we will discuss a few key gender issues regarding energy: women's workloads and time-use; health impacts of cooking, water, and sanitation; security and lighting; energy use in productive activities; access to information; gender-neutral project design in the energy sector; and the lack of women in technical education and professions. All these aspects highlight the need for improved policy and measures related to energy access that are essential for achieving overall well-being and equity for women, confirming that energy is a "critical enabler." ${ }^{133}$ This means that access to clean and affordable energy services enables women to improve their health and expand their livelihood opportunities, children can study better, and the opportunity for women to earn income is enhanced.

Women's domestic responsibilities are more burdensome due to inadequate access to energy. Women and girls are generally responsible for the provision of energy for household use, including gathering fuel or paying for energy for cooking; water collection for cooking, washing, bathing, watering and grazing animals, lighting and heating. They also have to manage the different types of energy used and needed in the household including deciding how much time and money to allocate to each one. Lack of access to cleaner and more convenient fuels dramatically increases the burdens on women as they carry out traditional household tasks, as well as income-generating activities. Affordable access to modern fuel is needed to address cooking, heating, and food processing needs, and to reduce reliance on fuelwood and traditional uses of biomass material. More efficient energy provision and fuel-

\footnotetext{
${ }^{133}$ S. Dutta. 2015. Unlocking women's potential towards universal energy access. Boiling Point: A Practitioner's Journal on Household Energy, Stoves and Poverty Reduction. Issue 66: Women, Energy and Economic Empowerment. Household Energy Network. p. 2.
} 
efficient technologies would reduce the time and share of household income spent on domestic energy needs of cooking, lighting, and heating. Freed up time and income of women can then be devoted to other activities leading to building assets, increased income, and improved women's and family's well-being.

In urban and rural areas, women and girls are generally responsible for managing water for domestic consumption. Where there are no water pumps, women are generally tasked with hauling water. Besides creating additional burdens on women's time and strength, water scarcity limits agricultural productivity, decreases family sanitation, and reduces women's ability to cook. Mechanical or electrified water pumping relieves women's burdens and makes basic household sanitation and subsistence activities much healthier and less time-consuming.

Women and girls are more at risk of health complications from using biomass for cooking. An important aspect of energy poverty is the serious and growing public health concerns related to indoor air pollution from burning traditional cooking fuel inside poorly ventilated homes, and physical injury during fuel wood collection. This is burdensome, time-consuming, and in some cases, a cause of insecurities if they have to go long distances and to unsafe places to collect fuel. ${ }^{134}$ These risks can be reduced by expanding the distribution and use of improved stoves. As mentioned above, cooking with gas is not an option for everyone, as only in some of the larger cities and adjacent townships piped natural gas connection is available at low price and LPG is not affordable to all.

Access to reliable energy can contribute to improving overall health, especially of women and girls. Provision of modern renewable energy services can improve general health by enabling access to potable water (solar water pumping), cleaner cooking facilities (biogas, solar electricity,

\footnotetext{
${ }^{134}$ United Nations Economic and Social Commission for Asia and the Pacific. 2013. Partnerships for Universal Access to Modern Energy Services: A Global Assessment Report by United Nations Regional Commissions. Working Paper Series. New York.
}

etc.), lighting, and solar refrigeration for vaccines. Despite improvements in public health provisions and overall health indicators, there are gender, class, and rural/urban differences in access to quality health care. Availability of renewable energy-based electrical energy can enable modern preventative, diagnostic, and medical treatment and care, including electrification of healthcare facilities and energy for medical equipment sterilization. This can also be done through the provision of electricity if accessible and affordable.

It is globally recognized that energy in the form of lighting contributes to human resource development. Global evidence has shown that the availability of lighting in the home increases women's literacy and educational levels, as well as extending the working day of women for incomegenerating activities. It makes it easier for girls and boys to study and do homework, and for their parents to continue their learning. Where there is no electricity, studying has to be done using a kerosene lamp, which increases costs and is a fire hazard. Education in institutional settings is also facilitated if there is electricity and running water.

Lighting contributes to safety and security in the public space, especially for women. In areas without electrical power, adequate lighting in the home, workplace, and public spaces is a critical need. Once public spaces are lit up after dark, women's mobility increases as their physical security is improved. They can come home later if necessary. They can go to public latrines at any time of the day and night. They can go to markets, hospitals, and even enjoy leisure activities. Lighting in public places also increases the safety of communities and allows women greater access to public gatherings.

Energy in various forms can contribute to increasing economic production and productivity by women, both inside and outside the home. In many cases, enterprises headed by women frequently have to be located in the home, and are therefore overlooked by energy agencies, which makes it difficult to provide energy services to women-owned enterprises. Reliable and efficient energy can improve 
enterprise development, and lighting permits income generation activities beyond daylight hours, which is important for home-based production. Energy can be used to power laborsaving machinery and increase productivity of enterprises. Since illumination does not require a great deal of electrical power, better lighting can be provided through low-cost lighting options using battery power, small stand-alone home systems, or decentralized village power systems. Availability of electrical energy opens doors to new business and economic opportunities for both women and men. Renewable energy itself can create new job opportunities for women. As newer technologies are employed more and more, skilled personnel are required, creating opportunities for employment, training, and capacity building for women and men.

Electricity can increase women's access to information. Electricity is essential for radios, televisions, and other electronic equipment used for information and communications. Women who are socially and culturally restricted in their ability to leave the home or participate in public affairs may rely more heavily than men on radios (or televisions, if available) for news, information, and entertainment. Radios can be operated with very little electricity and can be effective tools for information sharing, training, marketing, and public awareness programs. With access to electricity, information about technologies, training, marketing, and public awareness programs become available through devices like radio, television, and mobile phone. Nowadays, with better efficiency, quality, and price of off-grid appliances, many parts of rural Bangladesh are gradually becoming better connected to sources of information.

Mobile phones powered by off-grid energy sources can be effective in enabling women to utilize business, trade, and market information in addition to maintaining contact with family members and others, strengthening their social connections and safety. Phones also facilitate entrepreneurship opportunities since running telephone services can provide rural women with a business. Mobile phone coverage is high in the country and charging requires little energy. The total number of mobile phone subscriptions has reached 135.982 million at the end of June 2017. ${ }^{135}$ A large share of subscribers are women. In addition, there is a tremendous increase in the use of smart phones that is opening new horizons for people in rural areas. The number of smartphone users in Bangladesh was 8.2 million in the third quarter of 2015, which was $22.2 \%$ of mobile phone shipments, starting from $18 \%$ in the second quarter in 2014. ${ }^{136}$ Such phones can be used to promote women's empowerment with targeted apps designed to disseminate information.

Lack of decision-making power among women for choosing energy sources and technologies. Although renewable energy is the cleanest solution to energy scarcity, women and households headed by women usually do not have adequate information on technologies available and access to financing or collateral. The gendered power relations in the household can influence decision-making, behavior change, and/or adoption ofimproved energy services like implementing renewable technology and/or energy-efficient appliances. For example, in one small private sector project carried out in Gopalganj, two biogas power plants of 6 cubic meters were built to generate electricity for the households. When the small 1 kilowatt generators stopped working because of irreversible technical problems, it was not possible to diversify use of gas from the plants for cooking as the men were interested only in the electricity for lighting and TV. This illustrates how male views are given priority over women's practical needs. ${ }^{137}$

Development of energy infrastructure may have unintended negative effects on livelihood and income generation of families, especially women. These can be in the form of displacement of households from areas where infrastructures are

\footnotetext{
135 Bangladesh Telecommunication Regulatory Commission. www.btrc.gov.bd/content/mobilephone-subscribers-bangladesh-january-2016 (accessed 1 December 2016).

136 I. Husain. 2016. Smartphone users on the rise. Dhaka Tribune. 24 January. http://archive .dhakatribune.com/business/2016/jan/24/ smartphone-users-rise\#sthash.uBUYnqK8.dpuf

137 Author's own research project in Gopalganj in 2008.
} 


\begin{tabular}{|c|c|c|c|c|c|c|c|}
\hline \multicolumn{8}{|c|}{$\begin{array}{c}\text { Table 13: Female Participation in Some Fields of Technical Training } \\
\text { (Excluding Health and Medical Technology) }\end{array}$} \\
\hline \multirow[b]{2}{*}{ Types of Institution } & \multirow[b]{2}{*}{ Management } & \multicolumn{2}{|c|}{ No. of Institution } & \multicolumn{2}{|c|}{ No. of Teacher } & \multicolumn{2}{|c|}{ No. of Student } \\
\hline & & Total & Female & Total & Female & Total & Girls \\
\hline \multirow[t]{2}{*}{ Polytechnic Institute } & Public & 46 & 4 & 1,481 & 172 & 88,302 & 10,723 \\
\hline & Private & 172 & $\mathrm{n} / \mathrm{a}$ & 2,971 & 488 & 48,660 & 4,051 \\
\hline \multirow{2}{*}{$\begin{array}{l}\text { Technical School } \\
\text { and College }\end{array}$} & Public & 64 & $\mathrm{n} / \mathrm{a}$ & 1,132 & 119 & 36,112 & 4,860 \\
\hline & Private & 103 & $\mathrm{n} / \mathrm{a}$ & 1,681 & 340 & 28,124 & 9,350 \\
\hline \multirow{2}{*}{$\begin{array}{l}\text { Technical Training } \\
\text { Centre }\end{array}$} & Public & 38 & & 1,120 & 180 & 20,294 & 6,781 \\
\hline & Private & 43 & & 172 & 32 & 5,666 & 1,899 \\
\hline \multirow[t]{2}{*}{ Total } & & 466 & 4 & 8,557 & 1,331 & 227,158 & 37,664 \\
\hline & & & $0.86 \%$ & & $15.55 \%$ & & $16.58 \%$ \\
\hline \multirow{4}{*}{$\begin{array}{l}\text { Total (Technical } \\
\text { Education) }\end{array}$} & Public & 245 & & 4,862 & 656 & 173,424 & 28,279 \\
\hline & Private & 3,082 & & 21,460 & 4,486 & 434,752 & 137,195 \\
\hline & Total & 3,327 & & 26,322 & 5,142 & 608,176 & 165,474 \\
\hline & & & & & $19.53 \%$ & & $27.21 \%$ \\
\hline
\end{tabular}

being built. Environmental degradation might take place, for example, leading to a decrease in agricultural fertility, which can in turn increase poverty. As households are resettled in new areas, women may face various forms of genderbased violence related to migration and new roadways. On the positive side, improved infrastructure can lead to better economic opportunities. Employment may be generated during the construction phase. Projects can put into place various safeguards against the potential risks. Projects can make it mandatory to issue land titles for women or jointly for husband and wife under new resettlement plans to mitigate adverse impacts.

Women studying technical subjects and working in the energy sector are scarce. A final aspect that needs to be highlighted is the lack of women with technical education who can take on employment in fields related to energy and engineering (Table 13). Because of the low number of girls entering technical education, there are few women who are able to pursue professional growth in nontraditional or technical fields of work like the energy sector. This also implies that there are less women available to influence policies and practices in the sector.

In conclusion, reduced drudgery for women and increased access to nonpolluting energy for lighting, cooking, and other household and productive purposes can have dramatic effects on women's empowerment, education, literacy, nutrition, health, economic opportunities, and involvement in community activities. Gender differences in roles and responsibilities that arise from cultural norms and social practices can lead to various impacts in women's access to energy services, which in turn can have longterm consequences on gender equality and relations. ${ }^{138}$

\footnotetext{
${ }^{138}$ See following sources for further discussion of gender dimensions of energy: World Bank. 2015. Gender and Electricity Infrastructure: Key Issues. Energy Sector Management Assistance Program. https://www.google.com/search?q=Gender+and+ Electricity+Infrastructure\%3A+Key+Issues.+ Energy+Sector+Management+Assistance+ Program. + \&ie $=u t f-8 \&$ oe $=u t f-8 \&$ client $=$ firefox $-b$ Fatema, N. 2005. The Impact of Structural Gender Differences and its Consequences on Access to Energy in Rural Bangladesh. Paper for Asia Sustainable and Alternative Energy (ASTAE) Energy Wing of the World Bank Group. p. 20.
} 
Figure 5: Organogram of the Power Division of the Ministry of Power, Energy, and Mineral Resources

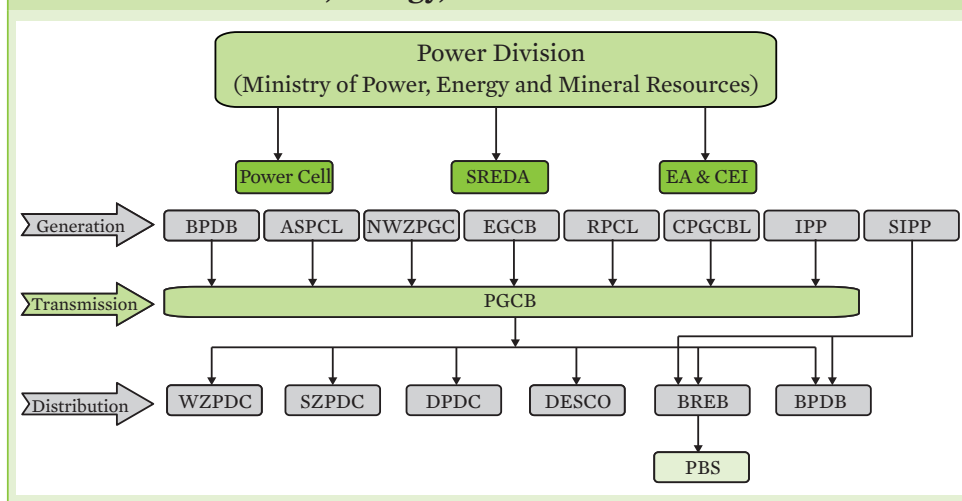

APSCL = Ashuganj Power Station Company Ltd.; EA \& CEI = Electric Advisor and Chief Electric Inspector; BPDB = Bangladesh Power Development Board; BREB = Bangladesh Rural Electrification Board; EGCB = Electricity Generation Company of Bangladesh Ltd.; DESCO = Dhaka Electric Supply Company Limited; DPDC $=$ Dhaka Power Distribution Company Limited; IPP = Independent Power Producer; NWZPGC = North-West Power Generation Company Limited; PGCB = Power Grid Company of Bangladesh Ltd.; PBS = Polli Biddyut Samity (Rural electrification cooperatives under BREB); RPCL = Rural Power Company Limited; SREDA = Sustainable and Renewable Energy Development Authority; SIPP = Small Independent Power Producer; SZPDC = South Zone Power Distribution Company Limited; WZPDC $=$ West Zone Power Distribution Company Limited.

Source: Government of Bangladesh, Ministry of Power, Energy and Mineral Resources (MPEMR). http://mpemr.gov.bd/about-us.

\section{Policy and Institutional Context for Addressing Gender Inequality}

\section{- Institutions in the Energy Sector and their Gender Focus}

Generation and distribution of power in different parts of the country is carried out by different organizations under the Ministry of Power, Energy and Mineral Resources. An organogram of the power generation, transmission, and distribution sector is shown in Figure 5. The independent power producers (IPPs) and the small independent power producers (SIPPs) are private sector organizations supplying electricity to the national grid.

Government agencies responsible for renewable energy and energy efficiency do not have gender strategies but address gender issues at project level. The recently initiated Sustainable and Renewable Energy Development Authority (SREDA) is the sole authority responsible for the development of renewable energy. SREDA promotes sustainable energy, working on renewable energy and energy efficiency toward building an energy-conscious nation to ensure energy security and to reduce carbon emission. Although SREDA does not have a strategy to address genderbased needs in the energy sector, gender elements may be integrated in the actual projects undertaken by its stakeholders. For example, in a project developed by ADB (Bangladesh Power System Enhancement and Efficiency Improvement Project), SREDA will be involved in capacity development for gender mainstreaming. It is overseeing the progress of the Bangladesh Country Action Plan for Clean Cookstoves, a project being implemented in association with the Global Alliance for Clean Cookstoves. All renewable energy projects of GIZ are also undertaken with the active guidance of SREDA, and gender issues are integrated in their implementation.

(i) Bangladesh Country Action Plan for Clean Cook stoves (CAP) makes the case for taking immediate action toward achieving the goal of $100 \%$ clean cooking solutions by 2030. The target of this CAP is to disseminate cook stoves to over 30 million households in Bangladesh. To achieve the goal of CAP, SREDA is implementing a project named "Household Energy Platform Program in Bangladesh" which is being implemented from July 2016 to June 2021. The main objectives of the project is to create awareness about improved cook stoves (ICS), ensure access to finance for entrepreneurs, create new business model, remove all barriers, introduce new technology, develop testing lab, reduce greenhouse gas emission, capacity building and research on new cooking solutions. This project aims to ensure clean efficient cooking for women resulting in their good health as well as time and money saved. Women are being engaged in entrepreneurship related to manufacturing, marketing, distribution, and maintenance of ICS.

(ii) SREDA is also promoting biogas technology in Bangladesh which is highly relevant for women's involvement as both users and service providers. 
(iii) In the upcoming renewable and energy efficiency projects, SREDA will keep options for capacity development in gender mainstreaming.

(iv) With other development partners, SREDA will take various planned measures focusing on gender issue in its upcoming projects and programs.

(v) SREDA also has the mandate to increase the renewable energy share in Bangladesh especially solar, wind, biomass, and biogas energy. In these sectors, SREDA will develop women technicians through training programs from various projects. With proper training, women can also be involved in off grid solar projects that will increase women's employment opportunities.

(vi) SREDA has plans for implementing pilot projects on Waste Management and waste to energy in municipal areas. By developing a suitable mechanism, women can be involved in this program.

(vii) SREDA has the goal of achieving $20 \%$ energy saving per GDP by 2030 . To achieve the target, women can be trained for household energy management to save energy.

Another government agency is Infrastructure Development Company Limited (IDCOL), which has been working since 2003 for the financing of renewable energy projects using concessionary funds of the World Bank, ADB, KfW, Japan International Cooperation Agency, Department for International Development of the United Kingdom, Islamic Development Bank, and many other development partners. It is working with the help of 57 partner organizations such as Grameen Shakti. ${ }^{139}$

Gender and energy concerns are integrated into rural infrastructure. LGED and RDA are implementers of rural infrastructure projects all over the country. LGED has been a pioneer in promoting gender concerns in many of its projects and programs such as providing streetlighting

\footnotetext{
139 It is a company set up by Grameen Bank for providing energy services in rural areas. Shakti means strength or power in Bangla.
}

and developing growth centers, keeping gender considerations in mind. It has set targets for employment of women, ensuring fair wages and sharing of profits from roadside plantations of LGED's road maintenance projects. RDA's communitybased biogas projects have been successful in including women in all stages of project implementation.

Development partners are involved in renewable energy. GIZ is one of the main development partners playing a technical role in supporting the government in its endeavors to promote renewable energy and energy efficiency through policy advocacy. The ongoing Sustainable Energy for Development program and Energizing Development Program work with SREDA to develop SREDA's institutional capacity to facilitate implementation of the planned measures. For its own activities in the country office, GIZ undertakes periodic gender analysis and includes genderfocused goals and activities in its projects and programs.

Some NGOs (e.g., Grameen Shakti and Centre for Mass Education in Science) and private firms (e.g., Prokaushali Sangsad, a consultancy firm with a view to bring together a group of engineers, architects, planners, economists, and other professionals to offer services in developmental activities of Bangladesh) are active and have been innovative in involving women.

\section{- National Policies in the Energy Sector and Their Gender Features}

The government's commitment to gender equity issues has been reflected in various policies of the country and being a signatory to many relevant international treaties. Bangladesh is a signatory to United Nations Framework Convention on Climate Change, which recognizes the importance of involving women and men equally in the treaty's processes and in the development and implementation of national climate policies that are gender-responsive. ${ }^{140}$ The relationship between energy needs, production, and

\footnotetext{
140 United Nations Framework Convention on Climate Change. 2014. Gender and Climate Change. http://unfccc.int/gender_and_climate_change/ items/7516.php
} 
encouragement of sustainable energy is increasingly recognized. The government has endorsed the Sustainable Development Goals (SDGs), of which Goal 7 is to "ensure access to affordable, reliable, sustainable and modern energy for all."

However, gender and energy issues have not received due recognition or been articulated in many of the relevant policies. This is evident from an assessment of energy issues in the national plans and policies provided in Table 14. Depending on the perceived users impacted by the policies, a gender focus has been included in some sector policies and guidelines, e.g., regarding rural women as beneficiaries of renewable energy programs. On the other hand, the National Women Development Policy 2011 does not mention energy at all. It states that the essential issues for women's economic empowerment are to give full and equal opportunity to women in health, education (including lifelong education and technical education), training (including incomegenerating training), and information and technology, but energy aspects are absent in most other gender-related public documents.

Energy policies are generally genderblind. Energy policies ignore differences in needs, access, and use between women and men. Most of them deal with largescale power generation, and no gender concerns are addressed. Documents on energy planning and renewable energy development have some references to women as users of household energy, but have no mention of how women can benefit from access to these energy technologies or how they can be involved in the sector. There is also no recognition in the policies that women's needs and use of energy are different from those of men because of their different reproductive and productive activities. The more formal sectors of gas (exploration, transmission, and distribution) and electricity (generation, transmission, and distribution) are still mainly treated as gender-neutral, i.e., not having any differential impacts on women and men. However, in recent years, increasing emphasis has been given to social considerations, which has resulted in inclusion of some gender aspects.
Household energy needs are recognized in some policies. Among the few policies that consider gender issues are the National Energy Policy (2004) and Bangladesh Energy Planning Project (1982-1984), which included assessment of biomass for household cooking energy as an important demand for energy in the rural areas. Data on availability of biomass is now being updated to help in area-based planning for cooking fuel and other uses. The Bangladesh Country Action Plan on Clean Cookstoves is the only plan endorsed by the government that is fully dedicated to women's energy concerns, specifically addressing women's traditional gender role of cooking for the family. ${ }^{141}$ The action plan defines a road map to disseminate cookstoves to over 30 million households in Bangladesh by 2030 in the shortest possible time. It identifies barriers to the large-scale adoption of clean cookstoves and fuels, as well as potential intervention options and mechanisms for quickly and effectively taking action. In addition to attending to the traditional aspect of women's work, the action plan is also aimed at improving women's health, reducing their drudgery, and alleviating their time poverty. It also seeks to motivate women to use new technology and draw lessons that can be used to support gender mainstreaming in other energy projects and programs.

Policy targets have also been set for promoting renewable energy development that benefit women from 2015 to 2021 . The goal set out in Renewable Energy Policy (2008) is to generate $5 \%$ of electricity by 2015 and $10 \%$ by 2020 from renewable sources. Most of the new capacity will be provided by solar (1,676 MW or $54 \%$ ) and wind (1,370 MW or $44 \%)$. There are also targets for biomass (47 MW), biogas (7 MW), and hydroelectricity (4 MW). ${ }^{142}$ Under the 500 MW Solar Program 20122016, the government has declared plans for promoting electricity generation based on solar energy. ${ }^{143}$ The significant experience

\footnotetext{
${ }^{141}$ Government of Bangladesh, MPEMR. 2013. The Country Action Plan for Clean Cookstoves. Dhaka.

${ }^{142}$ Footnote 123 (SREP), p. 10.

${ }^{143}$ Power Division, Ministry of Power, Energy and Mineral Resources. 2013.500 MW Solar Programme, 2012-2016: An Initiative to Promote Renewable Energy Programme in Bangladesh. Dhaka
} 
Table 14: Important Policies and Documents for the Energy Sector and Gender Considerations

Sl. No. Main Policy or Documents in the Energy Sector

A. National Energy Policy 2004

B. Power Pricing Framework 2004

C. Private Sector Power Generation Policy (revision 2004)

D. Policy Guidelines on Power Purchase from Captive Power Plant 2007

E. Remote Area Power Supply Systems Fund 2007

F. Renewable Energy Policy 2008

G. Bangladesh Private Sector Infrastructure Guidelines (revision November 2008)

H. Small Power Plant Policy

I. Policy Guidelines for Enhancement of Private Participation in the Power Sector, 2008

J. Power System Master Plan 2010

K. Action Plan for Energy Efficiency and Conservation, 2013

L. Solar Guide Book 2013

M. Country Action Plan for Clean Cookstoves, 2013

O. National Policy for the Advancement of Women by the Ministry of Women and Children Affairs
Directly Addresses Women's Energy Needs

Yes. The importance of provision for cooking energy is highlighted.

No

No

No

Yes. It promotes investment to facilitate electricity supply to households in remote areas.

Yes. The policy supports development of cooking fuels or technologies like biogas, improved cookstoves, solar electrification systems for households and community use, and other renewable energy technologies, which are to directly benefit women in their day-to-day activities.

No

No

No

No

Yes. All the sections take into consideration the impact of improved energy efficiency at the household level and the need for taking actions for raising awareness.

Yes. Women will benefit from the solar electrification, irrigation, and other technologies.

Yes. It attaches priority to reduced household air pollution, improved maternal and child health, women's economic empowerment through participation in cookstove-related entrepreneurship.

Yes. Solar electrification in unelectrified areas will enhance the quality of life of the population and reduce drudgery for women.

No

Source: Author.

in developing renewable energy projects is now being expanded in other off-grid technologies like solar mini-grids and solar irrigation pumps. Grid-connected technologies being planned for investment include utility-scale solar, wind, and wasteto-energy, which can provide scope for women's involvement both as users and service providers.

\section{Overall Good Practices and Lessons}

Gender analysis and formulation of gender strategy has been carried out for the Bangladesh Rural Electrification Board. The 77 Palli Bidyut Samities (PBSs) under the BREB have installed 


\section{Box 10: Gender and Energy Framework for the Bangladesh} Rural Electrification Board

\section{Gender and Energy End Goal}

Energy professionals working in partnership with the United States Agency for International Development (USAID) mission of Bangladesh must adopt more gender-sensitive strategies to meet the sustainable energy needs and priorities of both men and women stakeholders in rural Bangladesh.

\section{Gender-Specific Approaches}

(i) Increase the gender equity of workplace opportunities and improve the workplace environment for men and women professionals in energy institutions.

(ii) Broaden understanding of differences in rural men's and women's energy needs and interests in Bangladesh.

Source: USAID/Bangladesh. 2005. Gender Analysis and Recommendations for a Gender Plan of Action: Rural Energy Portfolio. DevTech Systems, Inc. and Institute of International Education, Inc. for International Development (USAID). Many gender awareness programs have also been undertaken through consulting activities of the National Rural Electric Cooperative Association. Another study was commissioned in 2005 by USAID where a gender and energy framework for USAID-supported activities was developed (Box 10). ${ }^{147}$

If the recommendations of the above studies are implemented, the countrywide network of BREB and PBS electricity cooperatives, as well as women and men in general, will benefit from the supply of uninterrupted power.

Bangladesh has also experienced progress in engaging women technicians in renewable energy initiatives in recent years. IDCOL program for renewable energy development has been successful with the implementation of solar home systems (SHSs) in the country, which resulted in expansion into other renewable energy and energy efficiency portfolio. Outputs of IDCOL projects are usually beneficial for women's empowerment because of the nature of the services provided by most of its project components, i.e., application of renewable energy technologies such as household electrification using solar panels and irrigation with solar water pumps. Currently, women technicians from NGOs are working in the field under IDCOL's SHS, improved cookstoves, and biogas programs. A training program for 27 women technicians was held by the private sector training institute of Prokaushali Sangsad. Some of the insights of the women involved are provided in Box 11.

Women technicians are trained for renewable energy systems. The Energy Sector Management Assistance Program funded the Ashden Award-winning project Opportunities for Women in Renewable Energy Technology Use in Bangladesh, which was implemented by Prokaushali Sangsad in 1999-2003. This was one of the first projects in Bangladesh addressing women in the energy sector (Box 12).

\footnotetext{
147 USAID/Bangladesh. 2005. Gender Analysis and Recommendations for a Gender Plan of Action: Rural Energy Portfolio. DevTech Systems, Inc. and Institute of International Education, Inc.
} 
Under this project, 35 women in the remote island of Char Montaz were trained in electronic assembly of direct current lamps and charge controllers to be used with SHS and battery-operated systems. Some of the reasons behind the project success include (i) using women's existing knowledge in the project design, (ii) providing compensatory training for gaps in technical and business knowledge, (iii) gaining male family members' support, (iv) providing incomegenerating opportunities, and (v) providing a service the community desired.

This idea was later scaled up by Grameen Shakti, and about 400 technical training centers (TTCs) were created to be run by women technicians of the SHS and improved cookstove program. The Energy Sector Management Assistance Program has also commissioned many reports on gender and energy in Bangladesh to disseminate these energy-related practices around the world.

Women's involvement in the community biogas project of Rural Development Academy is a promising initiative. The project has installed 106 community biogas plants in 36 districts of the country. The plants are around 130 cubic meters, supplying biogas to over 50 houses in each village, mostly for cooking. Unused gas from the plants is used for driving small generators to pump drinking water. Over 500 kilograms per day of organic fertilizer is also produced from the biogas slurry. In this project women are involved in all aspects of work, from rearing cattle to maintaining the biogas plant, from processing and selling bio slurry to waste management service.

Women are operating a plant using municipal waste for production of biogas. The project was implemented by Practical Action Bangladesh-assisted Gaibandha Municipality to establish a waste recycling (biogas) plant in 2012. Practical Action Bangladesh explored the potential of producing biogas from municipal waste through anaerobic treatment. The business of the plant is now managed by Chinnomul Mohila Samity (Bangla for very poor women's organization), an NGO based in Gaibandha. The project runs with income

\section{Box 11: Feedback from Women Technicians Trained in Solar Home Systems}

Female technicians face various problems at the workplace and in their career development, which include difficulty in getting promotions due to their inability to work after working hours, not having provision for weekly holidays at field level offices, inadequate transport, difficulty in renting accommodation, nonexistence of public toilets, sexual harassment, short maternity leave, and public attitude toward working women who are looked down upon as being from low-income families.

Women trainees also indicated that it is possible to increase household income by selling biogas as a commodity. Users of improved cookstoves have a healthier indoor environment, requiring less time for cleaning up. The availability of electricity can lead to new economic activities for women, leading to their empowerment.

Source: Author.

Box 12: Women in Bangladesh Make Battery-Powered Lamps

A project funded by the World Bank, the Energy Sector

Management Assistance Program, has been running on the island of Char Montaz in the south of Bangladesh since 1999. It aims to improve the lighting and indoor air quality of rural households by replacing traditional kerosene lamps with modern fluorescent battery-powered lamps. The fluorescent lamps are produced and marketed by a women's microenterprise, and so far about 1,000 households are using these lamps. The long-term potential is good with a market of 20,000 households in an area where grid extension within the next 20 years is highly unlikely.

The lamp business represents an important opportunity for the women to earn a relatively good wage. If a woman constructs and sells two lamps a day, she earns the wages equivalent to a skilled laborer, a significant opportunity which benefits her family and improves her social status. The remote community also benefited from the lamps, which are highly efficient and have low energy consumption. The advantage over kerosene lamps is the reduced risk of fire, as well as the elimination of smoke and other emissions which have negative health impacts. From the start, the project had recognized the importance of rural women's knowledge about local conditions and used major inputs by these women in the design of the energy service mechanisms. Recognizing that women had gaps in their knowledge of electronic components and the tools needed to work with the components, the project gave appropriate training to ensure that reliable lamps were produced. Training was also given in accounting and bookkeeping.

Source: H. Khan. 2001. Battery-Operated Lamps Produced by Rural Women. In S. Misana and G. Karlsson, eds. Generating Opportunities: Case Studies on Energy and Women. New York: UNDP. www.undp.org/content/dam/ undp/library/gender/Gender\%20and\%20Environment/Generating\%20 Opportunities-\%20Case\%20Studies\%20on\%20Energy\%20and\%20Women.pdf

from doorstep waste collection service from 1,237 households, and supplies piped biogas for cooking to 30 households. This is similar 
to the RDA project mentioned above, but works in the waste management sector and highlights the possibility of public-private partnership (PPP) efforts. The project has been successful in demonstrating that integrated approach to environmental improvement and increased access to clean energy at local level are very much feasible and offer an opportunity for women's economic involvement in energy sector.

International development organizations engaged in the energy sector of Bangladesh have also taken steps toward gender mainstreaming in their programs and projects. GIZ has programs on renewable energy and energy efficiency improvement in Bangladesh. GIZ Dhaka has undertaken many energy access and energy efficiency related projects in the country, creating supply and demand for sustainable energy solutions through building capacities of relevant stakeholders, promoting the application of energy efficient and renewable energy technologies. These include improved efficiency of rice parboiling furnaces and boilers, improved cookstoves, biogas technology, solar pumping for community drinking water supply, retained heat cooker, and pico-photovoltaic systems. ${ }^{148}$

Gender components are embedded in project tasks. Catalyzing Clean Energy in Bangladesh (CCEB), an ongoing project of USAID, has specific gender components embedded in all project tasks. Because of its project relationship with all the major organizations in the energy sector, CCEB can potentially influence other organizations to mainstream gender in their activities. CCEB has a gender strategy and action plan. A large component of the project supports promotion and commercialization of highly efficient massproduced stoves all over the country, which directly reduces women's workload and exposure to indoor air pollution, women being generally responsible for cooking. It also promotes training and certification of women as certified energy auditors.

An informal professional network is formed. The Gender and Energy Network

\footnotetext{
148 Mini photovoltaic systems.
}

Bangladesh is an informal network of professionals and organizations engaged in promoting gender awareness and gender mainstreaming activities in the energy sector since 2004. It is a voluntary organization and has conducted several studies, training programs, and awareness program under small grant funds from ENERGIA. These were intended for energy sector agencies and others, including BREB and PBS, Bangladesh Power Development Board (BPDB), LGED, Department of Public Health Engineering, and energy professionals. Services of organization like the Gender and Energy Network Bangladesh can be used to promote gender programs at the grassroots levels. ${ }^{149}$ The above activities have the potential for significant positive impacts on the intended beneficiaries, especially women. However, more in-depth studies over a longer period are needed to trace the impacts.

\section{Gender Equality in Energy: ADB Experience}

With its commitment to support the achievement of the United Nations Sustainable Development Goals (SDGs), including SDG 5 (Achieve gender equality and empower all women and girls), $\mathrm{ADB}$ is endeavoring to integrate gender considerations even in nontraditional sectors, such as energy infrastructure development. Table 15 presents the gender categorization of ADB-assisted projects in Bangladesh (see Box 5 for detailed definition of the gender categories). To date, no energy projects have been categorized as gender equity theme (GEN), which means that no energy project in ADB has been designed primarily to respond to gender issues in the sector. Nonetheless, the higher number of projects categorized as effective gender mainstreaming (EGM) and some gender elements (SGE) compared with the number of projects categorized as no gender elements (NGE) indicate the proactive efforts of project teams to integrate significant gender features in the projects. The Effective Gender Mainstreaming category means that the three projects are

\footnotetext{
${ }^{149}$ It is coordinated by Asma Huque, managing director of Prokaushali Sangsad Limited, who is also a focal point of ENERGIA.
} 
designed to directly respond to gender issues and achieve gender equality and women's empowerment results.

Some energy projects are discussed below with reference to the way in which gender considerations have been or could have been integrated. The contribution of projects to increasing women's access to energy has shown ADB's determination in helping to reduce women's energy poverty.

Providing increased household access to natural gas. As discussed above, women suffer most from the lack or irregular supply of cooking fuel as they are generally responsible for cooking. Its harmful effects on women's and children's health have also been discussed. Women as users have a vital role in reducing wastage of gas. Therefore, the expansion of provision of natural gas for households has an important gender dimension. The Natural Gas Access Improvement Project (2010) is an SGE category project where 200,000 households are to get access to gas through the new distribution network. ${ }^{150}$ The main activities under the project are (i) transmission capacity expansion of the national gas transmission network, (ii) safety and supply efficiency improvement of Titas gas field (design and implementation of safety measures to control gas seepage at problematic wells), (iii) access improvement in southwestern region, and (iv) supply and demand management. The project will have a positive impact on the environment and health of women who are vulnerable to indoor air pollution from the use of biomass and fuelwood, which will be replaced with natural gas.

Involving women in household energy management. The multitranche financing facility (MFF) Power System Expansion and Efficiency Improvement Investment Program (2012) is an NGE-categorized project. ${ }^{151}$ It is a typical power sector infrastructure development project where the main objective is to increase access to electricity connections. The project encompasses generation expansion through

\footnotetext{
150 ADB. 2010. Natural Gas Access Improvement Project. Manila (Project 38164-013-BAN).

151 ADB. 2012. Power System Expansion and Efficiency Improvement Investment Program - Tranche 1. Manila (Project 42378-015-BAN).
}

Table 15: Bangladesh Energy Projects by ADB Gender Category

Year Approved and Completed

2009-2012

2013-2016

Total
GEN

$\begin{array}{r}\text { EG } \\ \hline 1 \\ \hline 2 \\ \hline\end{array}$

EGM = effective gender mainstreaming, GEN = gender equity theme, $\mathrm{NGE}=$ no gender element, $\mathrm{SGE}$ = some gender elements.

Source: South Asia Department Gender and Development Database 2016.

efficiency improvement, transmission and distribution improvements, and a pilot solar irrigation component. Outputs envisaged are an additional 450,000 household electricity connections and 200 solar irrigation pumps benefiting around 4,000 poor farming families. The report and recommendation of the President (RRP) for Tranche 1 states that gender will not be addressed, but Tranche 2 will have more opportunities. However, previous experience has shown that if households are involved in project activities or as beneficiaries, it is possible to build in some degree of involvement of women (as well as men), for instance, as users and managers of household-level energy, ensuring that wastage does not take place and holding suppliers accountable. As part of the social and poverty analysis, the RRP states, "Increasing access and improving reliability of electricity will disproportionately benefit women by saving their time and allowing them to have more leisure time. Children will also directly benefit from the reliable power supply as they can extend their study hours." 152

Off-grid household electrification using renewable energy. The Second PublicPrivate Infrastructure Development Facility (2013) is an SGE-categorized project, and a component of this project is to provide a line of credit of $\$ 33$ million to IDCOL for promoting renewable energy

\footnotetext{
${ }_{152}$ ADB. 2012. Report and Recommendation of the President to the Board of Directors: Proposed Multitranche Financing Facility and Administration of Grant to People's Republic of Bangladesh: Power System Expansion and Efficiency Improvement Investment Program. Manila.
} 
systems in Bangladesh. ${ }^{153}$ This includes a \$10 million credit line for the SHS program implemented by IDCOL, which has been a major impetus for the rapid increase in SHS installations. This project addresses the infrastructure deficiencies in Bangladesh by providing long-term debt financing and catalyzing private sector participation through IDCOL. This will support poverty reduction through enhanced investment, economic growth, and increase in employment opportunities. The project design serves to attract commercial financing for infrastructure projects, thereby reducing the pressure on the public budget.

An additional objective of the project is to help provide the rural population and small and medium-sized enterprises (SMEs) in off-grid areas with access to environmentfriendly electricity. This component of the project directly benefits women through setting up of renewable energy systems, such as SHS or biomass installations, through a microfinance-based, direct sales program. These systems provide household electricity to areas unlikely to be reached by the grid in the near future, and while they do not support cooking, they can increase women's options and quality of life through, for example, reduced pollution by change of energy for lighting, particularly in kitchens, increased flexibility of schedules and security due to household lighting, and increased access to information through radio and television. All the physical aspects of IDCOL renewable energy projects (SHS, improved cookstoves, biogas, solar irrigation, solar mini-grids, and other renewables) have great potential for women's economic and social empowerment.

Creation of increased employment for women. Some projects in the energy sector have the objective of creating employment for women. According to the RRP on the Natural Gas Access Improvement Project (2010), as part of the project beneficiaries and benefits, it was identified that "industries such as jute mills, textile weaving factories, small

\footnotetext{
${ }^{153}$ ADB. 2013. Second Public-Private Infrastructure Development Facility. Manila (Project 42180-013BAN). https://www.adb.org/projects/42180-013/ main\#project-pds
}

cottage industries, and textile mills, and commercial entities such as restaurants and bakeries, will benefit, generating significant employment in the region and thus reducing poverty. ${ }^{154}$ The project will directly create 3,000 person-months of job opportunities during implementation."155

The Bangladesh-India Electrical Grid Interconnection Project (2015), an NGEcategorized project, also seeks to create employment. ${ }^{156}$ According to the RRP, "the project will generate jobs for the local communities during construction as a direct benefit. Other impacts of the project include greater production capacity of existing industries, and the creation of new industries, particularly in western Bangladesh that would generate employment."157 During implementation, efforts were made to ensure women were adequately represented and included.

The Bangladesh Power System Enhancement and Efficiency Improvement Project (2016), an EGM-categorized project, makes provisions for women's employment both within the PBS and for livelihoods opportunities for those affected by the project. Main project components are (i) strengthening transmission network in southern Bangladesh, (ii) improved distribution network control in Dhaka Electric Supply Company areas in Dhaka, (iii) enhancement of rural distribution network, and (iv) capacity development for sector planning and regulation. The project outputs are designed to deliver tangible benefits to women by directly improving their access to social services, economic, or financial resources or opportunities and basic rural infrastructures. A grantfunded TA is included in the project package, which will help in start-up of the various planned activities, specifically

${ }^{154}$ ADB. 2010. Natural Gas Access Improvement Project. Manila (Project 38164-013-BAN).

155 ADB 2010. Report and Recommendation of the President to the Board of Directors: Proposed Loans to People's Republic of Bangladesh: Natural Gas Access Improvement Project. Manila.

156 ADB. 2015. SASEC Second Bangladesh-India Electrical Grid Interconnection Project. Manila (Project 44192-016-BAN).

157 ADB. 2015. Report and Recommendation of the President to the Board of Directors: Proposed Loans to People's Republic of Bangladesh: SASEC Second Bangladesh-India Electrical Grid Interconnection Project. Manila (Project 44192-016-BAN). p. 8. 
focusing on addressing the gender issues through (i) model energy-based livelihoods developed with a focus on women's microenterprises development, (ii) enduser education for the safe and efficient use of energy, (iii) improving the environment in the PBSs for women employees and lifeline customers, and (iv) technical and skills training to avail of employment and livelihood opportunities in emerging areas including geographic information systems. ${ }^{158} \mathrm{~A}$ gender action plan (GAP) has also been prepared for the project.

Women solar pump operators breaking gender stereotypes. Outputs of the MFF Power System Expansion and Efficiency Improvement Investment Program (2012) include "members of 20 farmer organizations (males and females) trained on operation and maintenance of solar irrigation pumps by 2016"; and " 20 power sector personnel (males and females) trained on financial performance, auditing, and governance by 2016."159 In addition, 50 power sector personnel (males and females) were trained on investment planning, operations, planning, energy auditing, and monitoring in 2016. With adequate support, women solar pump maintenance groups can help break stereotypes about women's employment.

Formulation of gender frameworks for project design and implementation. While the Second Public-Private Infrastructure Development Facility (2013) has a gender action framework, this has been used as an overall reference and not as a basis for specific interventions. ${ }^{160}$ For this project, $\mathrm{ADB}$ provides loans directly to IDCOL. However, ADB loans to IDCOL and IDCOL's lending to sub-partners do not include gender mainstreaming as a mandatory condition. This could have been a good opportunity or entry point for implementation of ADB gender strategies related to gender mainstreaming, e.g., requiring the subcontractor to hire women

\footnotetext{
158 ADB. 2016. Summary Poverty Reduction and Social Strategy. Manila (49423-005-BAN).

159 Footnote 152 (RRP: Proposed Multitranche Financing Facility and Administration of Grant to People's Republic of Bangladesh: Power System Expansion and Efficiency Improvement Investment Program. Manila.).

160 Footnote 163 (Second Public-Private Infrastructure Development Facility)
}

and provide them the necessary working conditions, and requiring the projects supported by IDCOL to address gender discrimination and promote positive measures to address discrimination. However, IDCOL is in the process of preparing its own gender strategy, which should provide more concrete guidance for future activities.

Enabling Poor Women's Benefits from Enhanced Access to Energy in Hatiya Island (2015), an EGM-categorized project, addresses the development of a strategy to integrate gender. ${ }^{161}$ As part of the government's commitment to integrate gender and social considerations in the energy sector and to identify entry points to address gender and social inclusion issues related to the power subsector, $\mathrm{ADB}$ was asked in September 2014 to assist in developing a strategy to expand the integration of gender-related activities into the ongoing Power System Efficiency Improvement Project. The goal was to increase gender equality results by using new off-grid renewable energy options to maximize the hybrid power system in Hatiya Island. It provides the following:

(i) efficient electricity services and improved local power infrastructure, with a special focus on maximizing benefits for households headed by women by use of additional solarpowered equipment;

(ii) increased women's participation as entrepreneurs and service providers; and

(iii) gender-sensitive user education program module to improve household energy efficiency and safety, targeting households headed by women.

The GAP as developed under this TA project was implemented under the larger project. ${ }^{162}$ According to the TA report, "At the end of TA implementation, through capacity building and training, women beneficiaries in Hatiya are expected to

\footnotetext{
${ }^{161}$ ADB. 2015. Enabling Poor Women's Benefits from Enhanced Access to Energy in Hatiya Island. Manila (Project 48432-001-BAN).

162 Proposed Loan to People's Republic of Bangladesh for the Power System Efficiency Improvement Project. Manila (Loan 2769-BAN, Part B[ii]).
} 
be organized into electricity committees, which together with BPDB will support operation and maintenance of the pilot equipment and sale of electricity services (i.e., through prepaid meters). In addition, they will be responsible for livelihood promotion in Hatiya Island and work in the same manner as cooperative associations." 163

\section{- Challenges}

Regional consultations held with government, private sector, and NGOs for the formulation of the Gender Equality Diagnostic (GED) document pointed out some challenges which remain and need to be addressed. Some of these can be addressed in the short term with focused interventions, but many will require longterm sustained actions through changes in policies and program design.

A key gender challenge in the context of Bangladesh is that while there is a high demand for technical people in the energy sector, the number of women in these jobs is limited, and the sector has been traditionally male dominated. Education in science and technology is generally not promoted for women and girls, and the environment for technical work is not conducive to women. In Bangladesh, women participate in the workforce generally in areas that are deemed an extension of their gender roles. This results in less interest of families in sending girls to technical schools, and in limited opportunities for further training for those women already in the sector.

The challenges of a male-dominated sector are further compounded by the usual limitations faced by women working outside the home regarding a safe and secure working environment. Particularly in rural and peri-urban areas, the idea of women taking on traditionally male roles often leads to a dismissive or even degrading treatment of women in the technical workforce.

\footnotetext{
${ }^{63}$ ADB. 2015. Technical Assistance to People's Republic of Bangladesh for Enabling Poor Women's Benefits from Enhanced Access to Energy in Hatiya Island. Manila (Project 48432-001, Capacity Development Technical Assistance). pp. 3-4.
}

Women in Bangladesh are also constrained by family responsibilities within the home, which have to be attended to even with a full-time career in a demanding sector. As such, absence of alternative support systems is a major constraint on women's external activities.

Another key challenge for women working outside the home is the lack of access to private and suitable sanitary services. The regional consultations revealed that the government officials in energy-related field offices are not aware of how their ideas and information for new initiatives and projects, including those elements that relate to gender issues, could be forwarded to agencies like ADB or the government. In this regard, ADB could gain access to transformative ideas and opportunities with targeted and systematic outreach to technical and regional players, and help further the agenda for improved women's participation in the energy sector.

As discussed earlier, there is a lack of women at senior levels who can voice suggestions for improvement and concerns in all aspects of energy-related matters, and bring in a gender perspective to decisionmaking. The shortage of women at senior levels implies that there is a dearth of role models for younger women. Encouraging strong female role models for girls and women, both in technical education and in the work place, is also critical to overcoming the challenge of limited participation.

\section{Strengthening Gender Equality Approaches}

This section outlines actions that can be taken to strengthen gender equality approaches in the energy sector. Annex 1 provides a tip sheet on integrating gender perspectives in the energy projects. Annex 2 provides a list of useful resource materials. 


\section{Action Areas}

\section{Project Planning, Design, and Policy Making}

A. Review Energy Sector policies and programs to ensure that they address gender issues and that future policies or revisions of existing ones can be made more gender inclusive.

B. Use an area based planning methodology to address the energy needs of different locations and genders so that the energy needs of rural and urban areas for subsistence and productive requirements (e.g. agriculture, industries, and transport) are met on a sustainable basis.

C. Enable women users to play an active role in the planning and management of energy resources. Mechanisms and structures to ensure the accountability of service providers to the users should be established (if missing) and strengthened (where they exist). E.g., BREB and/or PBS.

D. Integrate technical assistance in large scale program loans from $\mathrm{ADB}$ to pilot innovative activities that would target women and their needs, and support more qualitative actions such as addressing women's energy needs.

E. Identify small pilots and initiatives that have the potential to be scaled up (e.g. RDA's biogas initiative, promotion of women entrepreneurs to form groups for marketing/direct sale of solar and energy efficient products).

F. Share results and lessons learned from “Enabling Poor Women's Benefits from Enhanced Access to Energy in Hatiya Island Technical Assistance" (2015) with researchers and project developers for possible replication and up scaling.

\section{Increasing Access to Energy}

G. Increase women's access to energy (power and fuel) to reduce their drudgery. Energy efficient technologies should be made available at affordable prices using consumer credits or other modalities to ensure profitable income generating activities for both men and women. Training on technology use should be provided to reduce women's workload and drudgery.

\section{Adaptation and Use of Technology}

H. Support organization and mobilization of women as consumers exercising agency through participation (including awareness raising activities on consumer's rights and proper energy use).

I. Continuously monitor and evaluate new technologies and projects and introduce means of obtaining user feedback, adapted to women and men's means of communication, in order to ensure modifications and adaptation to reflect the needs of the users, especially women, so that technical problems are sorted out and necessary modifications made.

\section{Increasing Employment for Women}

J. Undertake a detailed study to find out areas in which more women can be employed in the energy sector in the light of sectoral expansion plans. This should give an idea about many relevant aspects, including,

a. Activities in new, non-traditional areas that provide good employment opportunities

b. Women's barriers to pursuing careers in new fields and to accessing technology related to energy supply and use

c. Whether inclusion of boys and men can be useful in breaking stereotypes as has been shown in other countries.

\section{Responsibility}

Government of Bangladesh (GOB), Civil Society

Organizations (CSOs), private sector, and development partners

Planning Commission in coordination with Local Government Engineering Department (LGED), relevant government departments or ministries and local government bodies

Ministry of Power, Energy and Mineral Resources (MPEMR), Bangladesh Power Development Board (BPDB), Bangladesh Rural Electrification Board (BREB), LGED, Energy providers, public sector and private sector

$\mathrm{ADB}$

Planning Commission, MPEMR, development partners

\section{ADB, MPEMR}

MPEMR, Sustainable and Renewable Energy Development Authority (SREDA), BREB, Infrastructure Development Company Limited, development partners

Private training institutions with the help of appliance marketing companies

\section{All stakeholders}

National level project planners in the concerned ministries

Project design teams of development partners like ADB, World Bank (WB)

SREDA, BREB, LGED, Planning Commission, Small and Medium Enterprise (SME) Foundation, Ministry of Industries, Bangladesh Small and Cottage Industries Corporation (BSCIC), Ministry of Education

$\mathrm{ADB}, \mathrm{WB}$, and other development partners can commission studies though research organizations 


\section{Action Areas}

K. For government departments, such as BPDB, to employ a specific number of women for specific activities once they receive the necessary training.

L. Ensure market demand for future career development programs skills development programs coordinate with important private and public sector employers' associations, corporate and individual employers to seek and secure their support. Undertake pilot projects to rapidly assess the feasibility of planned activities in training and skills development of women before scaling up.

M. Promote women's entrepreneurship in manufacturing and marketing of potential energy saving technologies such as Clean Cook-stoves as long term business and employment opportunities.

N. Ensure enabling working environment by providing childcare, toilets, security for women employees

\section{Increasing Training Opportunities for Women}

O. Review different employment options to increase women's employment in the mainstream energy sector (e.g., electricity and gas) and establish linkages with training institutions and courses that cater to women and girls.

P. Promote women's training through scholarships and reservations of seats for women

\section{Institutional Capacity Building}

Q. Develop accountability for gender mainstreaming and monitoring in the sector.

R. Develop the capacity of institutions in the energy sector to address gender issues.

S. Develop the capability of teachers and students of technical universities in addressing women's needs and on the importance of women's participation in power and energy.

T. Coordinate with existing national networks by inviting to ongoing activities/programs and commissioning their services that can help in engendering and mainstreaming activities in different sectors by using their skills, experience and connections for promoting focused efforts in gender equality.

U. Develop women's leadership and representation at senior levels and on the board.

\section{Responsibility}

SREDA, BPDB, Rural Development Academy (RDA), Bangladesh Rural Development Board (BRDB), BREB

Planning Commission, MPEMR, SREDA, BREB, development partners, research organizations

MPEMR, SREDA, Ministry of Industries, ADB and other development partners, the Household Energy Platform (HEP), NGOs

SME Foundation, Bangladesh Technical Education Board (BTEB), Employers' Association, Chambers of Commerce and Industry, Women's Chamber of Commerce

Public and private sectors employers in the energy sector

Planning Commission, development partners, BPDB

Bangladesh Technical Education Board (BTEB)

\section{MPEMR with oversight from MOWCA}

Gender and Energy Network Bangladesh with support from Energy Sector organizations, MOWCA, and Development Partners

University Grants Commission and technical universities

Energy Sector organizations, SREDA, MOWCA, Development Partners

Energy sector organizations

Source: Author. 


\section{Annex 1: Tip Sheet on Questions and Design Features for Gender Mainstreaming in Energy Projects}

\begin{tabular}{|c|c|c|}
\hline $\begin{array}{l}\text { Examples of possible gender- } \\
\text { focused outcomes for } \\
\text { energy sector }\end{array}$ & $\begin{array}{l}\text { Examples of questions to consider } \\
\text { to formulate project strategies and } \\
\text { gender-related design features }\end{array}$ & Strategies and gender-related activities \\
\hline $\begin{array}{l}\text { Enhanced energy-based income- } \\
\text { generating activities and women's } \\
\text { entrepreneurship in rural and } \\
\text { urban areas }\end{array}$ & $\begin{array}{l}\text { Is reliable and adequate electrical } \\
\text { and heating energy required for } \\
\text { income-generating activities } \\
\text { available in the target area? What are } \\
\text { the constraints on access to energy } \\
\text { faced by women? } \\
\text { - Is it possible to provide the energy } \\
\text { economically? Will energy supply be } \\
\text { affordable for the enterprises? } \\
\text { - Are there specific occupations that } \\
\text { have been traditionally prevalent } \\
\text { in the area that can be supported } \\
\text { so that large number of women } \\
\text { and men can benefit by improving } \\
\text { availability of energy (e.g., village } \\
\text { weavers or potters)? } \\
\text { - Can there be discussions with } \\
\text { representatives and associations } \\
\text { of mainstream industries for } \\
\text { developing backward linkages with } \\
\text { large number of small producers in } \\
\text { the area? } \\
\text { - How will women and men be } \\
\text { informed about new opportunities? } \\
\text { Do women have the capacity to run } \\
\text { enterprises or do they need training } \\
\text { and mentoring? Who will provide } \\
\text { the training, how, and for how long? }\end{array}$ & $\begin{array}{l}\text { - Develop energy projects to increase } \\
\text { supply of electricity and other types of } \\
\text { energy. } \\
\text { - Carry out awareness programs for } \\
\text { residents, business community, local } \\
\text { government representatives, and local } \\
\text { officials on gender and energy issues, } \\
\text { available and potential opportunities for } \\
\text { participation of women in energy-related } \\
\text { income-generating activities, and how } \\
\text { more women can be involved in them. } \\
\text { - Partner with national and local } \\
\text { nongovernment organizations (NGOs) } \\
\text { and private companies to implement } \\
\text { pilot livelihood programs. Activities } \\
\text { can include training on use of labor } \\
\text { and energy-saving appliances, and offer } \\
\text { financial and business management, } \\
\text { credit, market access, marketing } \\
\text { strategies, etc. } \\
\text { - Conduct skills and technical training on } \\
\text { various processing, manufacturing, and } \\
\text { maintenance technologies for running } \\
\text { energy-based enterprises. } \\
\text { - Develop regional quality assurance- } \\
\text { related services (e.g., testing of energy } \\
\text { efficient stoves, solar lighting products) } \\
\text { for businesses with potential for } \\
\text { engagement of women. } \\
\text { - Arrange for capable institutions to } \\
\text { provide initial mentoring and hand- } \\
\text { holding for the entrepreneurs, both } \\
\text { women and men, and all aspects of } \\
\text { running small businesses. } \\
\text { existing programs for promoting women's } \\
\text { entrepreneurship. }\end{array}$ \\
\hline $\begin{array}{l}\text { Institutional awareness raised and } \\
\text { capacities built among government } \\
\text { organizations for provision of } \\
\text { gender-responsive services }\end{array}$ & $\begin{array}{l}\text { What is the level of awareness } \\
\text { of gender-energy linkages in the } \\
\text { specific organizations? } \\
\text { - Are those involved within program } \\
\text { planning departments adequately } \\
\text { briefed on gender equity in energy } \\
\text { issues? }\end{array}$ & $\begin{array}{l}\text { Build gender awareness of all officials by } \\
\text { requiring attendance to targeted training } \\
\text { programs and participation in action } \\
\text { plan development. }\end{array}$ \\
\hline
\end{tabular}




\begin{tabular}{|c|c|c|}
\hline $\begin{array}{l}\text { Examples of possible gender- } \\
\text { focused outcomes for } \\
\text { energy sector }\end{array}$ & $\begin{array}{l}\text { Examples of questions to consider } \\
\text { to formulate project strategies and } \\
\text { gender-related design features }\end{array}$ & Strategies and gender-related activities \\
\hline & $\begin{array}{l}\text { - Are women currently employed } \\
\text { in the organization? If so, in } \\
\text { what capacities? Are they well } \\
\text { represented in the management, } \\
\text { high-level committees, or } \\
\text { the boards? } \\
\text { - Do women have equal access to } \\
\text { training opportunities? Is there a } \\
\text { human resource strategy to promote } \\
\text { gender equality? } \\
\text { - Has any gender audit been } \\
\text { conducted? What are the findings } \\
\text { and lessons learned from this? } \\
\text { - Does the organization apply good } \\
\text { labor and safety standards? } \\
\text { - Are women's concerns adequately } \\
\text { reflected in the monitoring and } \\
\text { supervision schemes? }\end{array}$ & $\begin{array}{l}\text { - Train officials and staff (male and female) } \\
\text { in gender issues of risk mitigation } \\
\text { strategies, social safeguards, and all } \\
\text { similar areas; in the development } \\
\text { and implementation of action plans } \\
\text { and programs; and in performance } \\
\text { commitments. They should be able } \\
\text { to apply the skills acquired from the } \\
\text { training, and translate the skills to } \\
\text { provision of improved gender- } \\
\text { responsive services. } \\
\text { - Ensure implementation of any gender- } \\
\text { related plans that may have come out } \\
\text { of gender audits or gender action } \\
\text { plans (GAPs). } \\
\text { - Establish gender sensitivity and secure } \\
\text { work environment for women. } \\
\text { - Establish mechanisms to institutionalize } \\
\text { monitoring of existing gender equality } \\
\text { principles in the workplace. }\end{array}$ \\
\hline $\begin{array}{l}\text { Enhanced women's participation } \\
\text { in decentralized, community- } \\
\text { based, and/or managed energy } \\
\text { distribution models, and } \\
\text { strengthened technical and } \\
\text { organizational capacity }\end{array}$ & $\begin{array}{l}\text { - Are there any community-based } \\
\text { energy distribution systems in } \\
\text { the target area? If so, are women } \\
\text { involved in them? Are women } \\
\text { interested? What are the barriers to } \\
\text { their participation? } \\
\text { - Are there women with the required } \\
\text { skill and education to manage this } \\
\text { kind of community-based systems? }\end{array}$ & $\begin{array}{l}\text { - Involve women's NGOs and community- } \\
\text { based organizations in the activities. } \\
\text { - Train women to be employed as } \\
\text { operators, technicians, managers, etc. } \\
\text { - Provide gender training to existing } \\
\text { institutions and the community to accept } \\
\text { women as service providers. } \\
\text { - Conduct gender-sensitive user-education } \\
\text { programs for consumers. } \\
\text { - Invest in research and development on } \\
\text { technical and socioeconomic aspects of } \\
\text { rural energy systems. }\end{array}$ \\
\hline $\begin{array}{l}\text { Improved energy access for } \\
\text { urban poor households in areas } \\
\text { unserved by natural gas network } \\
\text { (e.g., liquefied petroleum gas } \\
\text { cylinders, municipal waste-based } \\
\text { community biogas systems, } \\
\text { improved cookstoves, etc.) }\end{array}$ & $\begin{array}{l}\text { - What is the nature and extent of } \\
\text { energy gap experienced by the target } \\
\text { groups, and how are women affected } \\
\text { by the lack of service? } \\
\text { - Is building of gender awareness } \\
\text { required for project developers } \\
\text { and designers? } \\
\text { - Is gender-disaggregated background } \\
\text { information available? } \\
\text { - What are the options available } \\
\text { for large-scale intervention? Are } \\
\text { affordable proven technologies } \\
\text { available? Are there existing } \\
\text { marketing channels that can } \\
\text { accommodate the new solutions? } \\
\text { What other new channels can } \\
\text { be developed? }\end{array}$ & $\begin{array}{l}\text { - Engage in community dialogues to } \\
\text { include views of both men and women } \\
\text { about their needs and preferences, and } \\
\text { various proposed technology options } \\
\text { being offered. Identify the difference } \\
\text { between women's and men's ability } \\
\text { to participate during the problem } \\
\text { identification and take necessary steps to } \\
\text { solve them. } \\
\text { - Take into account women's knowledge } \\
\text { and their views about design features. } \\
\text { - Commission baseline studies to find } \\
\text { out the situation on the ground and to } \\
\text { collect and use sex-disaggregated and } \\
\text { gender-specific data to raise awareness } \\
\text { and inform program and project designers } \\
\text { about women's energy needs. }\end{array}$ \\
\hline
\end{tabular}


Annex 1 continued

\begin{tabular}{|c|c|c|}
\hline $\begin{array}{l}\text { Examples of possible gender- } \\
\text { focused outcomes for } \\
\text { energy sector }\end{array}$ & $\begin{array}{l}\text { Examples of questions to consider } \\
\text { to formulate project strategies and } \\
\text { gender-related design features }\end{array}$ & Strategies and gender-related activities \\
\hline & $\begin{array}{l}\text { - How can women be involved as } \\
\text { service providers? What support } \\
\text { is required to promote women's } \\
\text { equitable involvement? } \\
\text { - Do analyses on potential } \\
\text { implications of adopted technologies } \\
\text { take gender into account? }\end{array}$ & $\begin{array}{l}\text { - Ensure availability of a greater choice } \\
\text { of efficient, nonpolluting cookstove } \\
\text { technologies using renewable and } \\
\text { traditional energy sources. } \\
\text { - Arrange for user education programs to } \\
\text { raise awareness about energy-efficient } \\
\text { technologies and induce positive } \\
\text { behavior patterns. }\end{array}$ \\
\hline
\end{tabular}




\section{Annex 2: Useful Resources for Further Reading on Gender Equality in Energy}

\begin{abstract}
Bangladesh-specific research and analyses on gender and energy

Other research and analysis articles on gender and energy
\end{abstract}

- Asian Development Bank (ADB). 2013. Bangladesh: Increasing Access to Energy. Manila. http://www.adb.org/publications/bangladesh-increasing-access-energy

- A. Berthaud et al. 2004. Integrating Gender in Energy Provision Case Study of Bangladesh. Washington, DC: World Bank. https://openknowledge.worldbank.org/ handle/10986/18856

- N. Fatema. 2005. The Impact of Structural Gender Differences and its Consequences on Access to Energy in Rural Bangladesh. Paper for Asia Sustainable and Alternative Energy (ASTAE) Energy Wing of the World Bank Group.

- S. Sheheli. 2012. Improving Livelihood of Rural Women Through Income Generating Activities in Bangladesh. PhD diss., Humboldt University of Berlin.

- ADB. 2012. Gender Toolkit: Energy: Going Beyond the Meter. Manila.

- J. Clancy and S. Dutta. 2005. Women and Productive Uses of Energy: Some light on a shadowy area. Paper presented at the United Nations Development Programme (UNDP) Meeting on Productive Uses of Renewable Energy, Bangkok, Thailand, 9-11.

- K. Dhanapala. 1998. Beyond project boundaries, improving gender impacts of village micro hydro systems. ENERGIA News. 2(3). pp. 12-14.

- S. Dutta. 2005. Energy as a key variable in eradicating extreme poverty and hunger: A gender and energy perspective on empirical evidence on MDG \#1. Report to ENERGIA and Department for International Development Knowledge and Research Programme Research Project R8346.

- For a repository of articles and resources on gender and energy, see www.energia.org

- G. Kohlin et al. 2011. Energy, Gender and Development: What are the Linkages? Where is the Evidence? Policy Research Working Paper Series. No. 5800. Washington, DC: World Bank.

- Norad. 2011. Gender Equality in Financing Energy for All: Gender-responsive energy financing can contribute to basic human rights and economic efficiency. Norad Report 20/2011 Discussion. Paper developed by Norad's gender team in cooperation with ETC/ENERGIA \&Nord/Sør-konsulentene consortium. http://www2.unwomen.org/-/ media/files/un\%20women/grb/resources/gender\%20equality\%20in\%20financing\%20 energy\%20for\%20all.pdf?vs $=425$

- S. Oparaocha and S. Dutta. 2011. Gender and energy for sustainable development. Current Opinion in Environmental Sustainability. 3(4). pp. 265-271. www.sciencedirect .com/science/article/pii/S1877343511000601

- UNDP. 2004. Energy and Gender for Sustainable Development: A Toolkit and Resource Guide. New York.

- UNDP. 2007. Will tomorrow be brighter than today? Addressing gender concerns in energy for poverty reduction in the Asia-Pacific region. Regional Energy Programme for Poverty Reduction (REP-PoR), UNDP Regional Centre in Bangkok http://www.undp.org/ content/dam/rbap/docs/Research\%20\&\%20Publications/environment_energy/RBAPEE-2006-Will-Tomorrow-Be-Brighter-than-Today.pdf

- United Nations Regional Commissions. 2013. Partnerships for Universal Access to Modern Energy Services: A Global Assessment Report on Public-Private Renewable Energy Partnerships.

- World Bank. 2013. Integrating Gender Considerations into Energy Operations. ESMAP Knowledge Series. No. 014/13 .Washington, DC: Energy Sector Management Assistance Program, World Bank. p. 3. 


\section{Bangladesh Gender Equality Diagnostic of Selected Sectors}

Annex 2 continued

Guides and case studies on gender and energy

ADB practical resources for project planning and management in the sector
- H. Khan. 2001. Battery-Operated Lamps Produced by Rural Women. In S. Misana and G. Karlsson, eds. Generating Opportunities: Case Studies on Energy and Women. New York: UNDP. www.undp.org/content/dam/undp/library/gender/Gender\%20 and\%20Environment/Generating\%20Opportunities-\%20Case\%20Studies\%20on\%20 Energy\%20and\%20Women.pdf

- ADB. 2003. Gender Checklist: Resettlement. Manila. https://www.adb.org/publications/ gender-checklist-resettlement

- ADB. 2006. Gender, Law, and Policy in ADB Operations: A Tool Kit. Manila. https://www.adb.org/documents/gender-law-and-policy-adb-operations-tool-kit

- ADB. 2009. Project Gender Action Plans: Lessons for Achieving Gender Equality and Poverty Reduction Results. Manila. https://www.adb.org/publications/project-genderaction-plans-lessons-achieving-gender-equality-and-poverty-reduction

- Further resources and guides on gender action plans, see www.adb.org/themes/gender/ project-action-plans.

- Other ADB gender checklists and toolkits are currently available for a number of themes (including water supply and sanitation, urban development and housing, etc.), and others are planned (including one on public sector management): www.adb.org/ themes/gender/checklists-toolkits. 


\section{Skills, Vocational, and Tertiary Education Sector}

\section{Summary}

Skills, vocational, and tertiary education is critical for enabling women and girls to enter the workforce on equal terms with men and to access better conditions, better pay, and better prospects. Gender discrimination and inequality in secondary, technical, and tertiary education as well as stereotyping in the choice of academic courses and subjects, and employment persist. To overcome this, it is crucial for women to make the most of available opportunities, such as, among others, resources for entrepreneurship and use of new information and communication technology. This would allow them to shift to more skilled employment with better pay and working conditions instead of staying as low-paid domestic workers subject to various forms of exploitation. However, challenges abound because, despite the initiatives for institutional reform and ensuring quality and market responsiveness, the skills, vocational, and tertiary education subsectors remain institutionally complex because they encompass both public and private institutions. NGOs too have traditionally played an active role in skills training as part of their poverty alleviation initiatives.

The elaboration of the National Skills Development Policy (NSDP), which is complemented by a separate draft gender policy on technical and vocational education and training (TVET), is an important step toward gender equality. These policy documents create the conditions for a wellcoordinated TVET delivery system, which previously was not regulated or harmonized. The strategic focus is to ensure women's access to needs-based education and market-oriented skills leading to sustainable gainful employment. The state realizes that given the magnitude and complexity of this issue, it cannot address it alone in a holistic manner. Therefore, it is making efforts to build interagency collaboration with NGOs and the private sector. Greater emphasis also needs to be put on creating awareness of the range of opportunities that technical and vocational education and training (TVET) can open.

The multisectoral efforts to achieving gender equality results in TVET can build on a number of good practices in the private and public sector, such as those developed by the Underprivileged Children's Education Programs (UCEP), Dhaka Ahsania Mission (DAM), and Building Resources Across Communities (BRAC) Skills Training Program for Advancing Resources (STAR) Program. The BRAC STAR Program is an example of a response to private sector needs in integrating TVET with the markets. ADB collaboration with government ministries and agencies has also sought to address some of the institutional constraints and to increase institutional capacity by developing the capacity and increasing the number of women secondary teachers. Some interventions have sought to address stereotypes by encouraging science education for girls. Others have addressed the need for greater security of girls by ensuring that infrastructure responds to their needs and concerns. There is a better understanding of the gaps and barriers that remain for women and girls and of how to address them, in the skills and vocational part of secondary education and in tertiary education.

The final section of this chapter outlines the possible actions to strengthen gender equality approaches in skills development sector. Annex 1 provides a tip sheet on integrating gender perspectives in skills, vocational, and tertiary education projects. Annex 2 provides a list of useful resource materials. 


\section{Sector Context}

Skills and vocational training (with emphasis on secondary education), and tertiary education are educational subsectors with indispensable roles in gender equality and women's empowerment. They are important means for removing the barriers to women's and girls' entry into the workforce, and for developing and recognizing their potentials to be on an equal footing with men and boys. For clarity in the discussion of the gender aspects of these subsectors, Box 13 provides definitions of important terms that will be used subsequently.

\section{- Institutional Setup}

The education system of Bangladesh functions under two separate ministries: (i) Ministry of Primary and Mass Education responsible for pre-primary, primary, and mass education; and (ii) the Ministry of Education (MOE) responsible for secondary and tertiary education. Secondary or post-primary education in the general stream is imparted by junior secondary schools (grades 6-8), senior secondary schools (grades 9-10), and higher secondary schools, also known as intermediate colleges (grades 11-12).

Technical and vocational education and training is the most significant element of the skills development sector. It encompasses the initiatives of the government, NGOs, and private sector.

The public sector skills development refers mainly to the technical and vocational education and training system. Vocational training and skills development activities are coordinated and implemented by two ministries-Ministry of Labour and Employment and Ministry of Expatriates' Welfare and Overseas Employment.

- Technical training programs are set up under various ministries. Under the Ministry of Labour and Employment, Bureau of Manpower, Employment and Training (BMET) offers vocational training at 22 technical training centers (TTCs), which are in the urban industrial areas and are under the remit of polytechnic schools. TTCs provide vocational training to medium-level technicians (referring to those with less training and more restricted scope of practice than professionals), and formal certificates and accreditation through licensing bodies. The technical education is placed under the MOE. In addition, other ministries and departments also have technical training programs. The Ministry of Agriculture, Department of Youth Development, Ministry of Industries, Ministry of Social Welfare, and Ministry of Women and Children Affairs also provide training to women on nontraditional skills like plumbing, masonry, electronics, and others. The Ministry of Health and Family Welfare conducts occupational training programs such as for radiographers, laboratory technicians, and sanitary technicians.

- Under the Ministry of Education, vocational training is provided at 64 technical schools and colleges. Technical schools and colleges are formerly known as vocational training institutes. Their purpose is to provide skills for employment through practical training. Levels of certification provided are (i) secondary school certificate (SSC)

\section{Box 13: Some Definitions for this Chapter}

- Skills development. It includes all forms of training and education occurring in the formal, nonformal, and on-the-job training.

- Technical and vocational education and training. It refers to those aspects of the educational process involving, in addition to general education, the study of technologies and related sciences, as well as the acquisition of practical skills, attitudes, understanding, and knowledge relating to occupations in various sectors of economic and social life.

- Technical vs. vocational schools. Technical schools teach the theory and science behind the occupation, while vocational schools take a more hands-on approach to teaching the skills needed to do the job successfully.

- Tertiary education. Also referred to as third stage, third level, and post-secondary education, it is the educational level following the completion of a secondary education. It includes universities as well as institutions that teach specific capacities of higher learning such as colleges, nursing schools, research laboratories, and distance learning.

Source: K. King and R. Palmer. 2006. Skills, Capacities and Knowledge in the Least Developed Countries: New Challenges for Development Cooperation. Background paper produced for the 2006 UNCTAD Least Developed Countries Report, Mobilizing and Developing Productive Capacity for Poverty Reduction, Centre of African Studies, University of Edinburgh. 
vocational, a 2-year course involving classes IX and $\mathrm{X}$; and (ii) higher secondary certificate (HSC) vocational, a 2-year course involving classes XI and XII. In Bangladesh, general education is compulsory up to grade 8 . After that there is an option to continue education in various branches like humanities, science, as well as vocational education. Passing SSC and HSC vocational courses opens the door for polytechnic and diploma engineering.

There is a long standing recognition of the contributions of the private sector and nongovernment organizations to technical and vocational education and training. For skills development purposes, NGOs have an advantage due to their presence and experience in rural settings dealing with poverty issues and raising awareness on social, economic, and environmental issues. Their roles in the communities are recognized. Their interventions have created awareness and confidence among rural women. Some of the features of the roles of the private sector and NGOs in TVET are the following:

- The main distinguishing factor between a private vocational institute and NGO vocational provider is that the former is for-profit, while the latter is nonprofit.

- Private skills providers are different in their composition and status. Registered providers can issue governmentapproved certification for completing a course. There are at least 119 private SSC vocational institutes in Bangladesh. Other variants of private vocational institutes include commercial colleges and agricultural institutes. There are several private non-registered institutes that provide vocational training; the actual number is not known. A substantial number of these vocational training programs are IT-based.

According to ADB (2008), over 100 NGOs have undertaken initiatives specifically targeting vocational training for the poor. ${ }^{164}$ However, although the NGO and private skills providers are $84 \%$ of the total sector and serve $52 \%$ of the total number

\footnotetext{
164 ADB. 2008. Education Sector in Bangladesh: What Worked Well and Why under the Sector-Wide Approach? Manila.
}

of students receiving basic skills, they are operating at below capacity. It is important to emphasize that the private sector is closer than the government or NGO sector to the market and the demand for skills. ${ }^{165}$

Tertiary education providers are growing. Tertiary education in Bangladesh is comprised of two categories of institutions: (i) degree-awarding universities and colleges affiliated with the National University; and (ii) private universities and colleges, of which there are more than $50 .{ }^{166}$ Since the early 1990 s, the country has experienced a spectacular growth in private universities-mostly in and around Dhaka and in a few other large cities. Bangladesh has 37 public universities providing education to the bulk of higher studies students. ${ }^{167}$ These universities are funded by the government while managed as selfgoverned organizations. There are 3,383 colleges in Bangladesh providing tertiary education, of which 3,145 are private and 238 are public. ${ }^{168}$ These colleges are affiliated with the National University, which awards the degrees.

Overall, access to tertiary level education in Bangladesh is still very limited. Only about $12 \%$ of the year 12 graduates enter higher education. More than $80 \%$ of these students are in colleges. Others are in the public and private universities.

\section{Key Gender Issues in the Sector}

\section{- Participation of Girls in Secondary Education}

Higher levels of education and skills facilitate women's economic engagement. The increase in women's education has facilitated their integration in the labor market. In Bangladesh, $60 \%$ of the increase in women's paid work during the 2000 s

\footnotetext{
${ }^{165}$ Sabur, Z.U. 2007. Context analysis/Stock taking on Skill Development in Bangladesh. Prepared for Swiss Agency for Development and Cooperation.

166 Bangladesh Bureau of Educational Information and Statistics. 2015. Bangladesh Education Statistics. Government of Bangladesh. Dhaka.

167 Bangladesh Bureau of Statistics (BBS) 2013 . Statistical Year Book. Government of Bangladesh p. 261.

${ }^{168}$ Government of Bangladesh, Bangladesh Bureau of Educational Information and Statistics. 2008. Bangladesh Education Statistics. Dhaka.
} 
was concentrated in urban areas and in manufacturing sectors (including garments manufacturing). One of the reasons is that motivation for female education is much higher in urban areas than in rural areas. ${ }^{169}$

However, despite a significant increase in participation rate and reduction in disparity between boys and girls, women and girls do not benefit from secondary or technical education as much as men and boys do. Generally, skills development and vocational and technical education systems remain flawed and ineffective. Poor quality affects boys and girls, but there are ways in which girls are particularly or differently affected, for example, through unequal treatment of girls and boys in the classroom, a curriculum that reflects gender stereotypes, and subject streaming that channels girls into the humanities rather than into science and commerce, which arguably create better possibilities of employment. Further, the need to invest in tutoring to counter poor quality teaching and to pass exams is particularly unfavorable for girls, who are less likely than boys to benefit from such additional expenditures. Poor physical facilities and the lack of toilets are particular problems for girls. Quality of education for girls is also undermined by the harassment and insecurity they experience within school premises and on the way to school. The difficulties girls have in secondary education, especially science education, also have an impact on access to technical and vocational education, on the choice of skills, and ultimately on the kinds of occupations they can access.

Stipends have facilitated the participation of girls. The girls have benefited from the stipends introduced by the government in secondary education. ${ }^{170}$ The governmentinitiated Female Stipend Project was established in 1982 with the purpose of delaying marriage, empowering girls and women, and enhancing employment opportunities. After the World Conference on Education for All in Thailand in March 1990, the project was taken up by

\footnotetext{
169 Footnote 15 (Labour Force Survey 2013).

170 J. Raynor and K. Wesson. 2006. The Girls' Stipend Program in Bangladesh. Journal of Education for International Development 2.2. http://www. equip123.net/JEID/articles/3/Bangladesh.pdf
}

the government in a much larger scale under the title, Female Secondary Stipend Project. Even though this has increased substantially the participation of girls, it has not fully addressed the problem of poor school completion among girls and their inability to enter sustainable livelihood activities. The government therefore is in the process of "vocationalizing" secondary education parallel to the current separate stream of vocational education. ${ }^{171}$

While the increased participation of girls is having positive social effects, it is not translating into further education and gainful employment. As Table 16 shows, the achievements of girls at secondary level have outpaced those of boys in terms of gross enrollment. However, dropout rates in secondary school (grades 9-10) are high for both girls and boys, but even higher among girls; completion rates are low for both, but even lower among girls.

Table 16 and Table 17 show, among others, the increase in secondary education enrollment. This has benefited from government interventions, particularly the Female Secondary Stipend Project for rural girls supported by the government and donors.

\begin{tabular}{|c|c|c|c|c|c|c|}
\hline \multicolumn{7}{|c|}{$\begin{array}{c}\text { Table 16: Gross Enrollment, Completion, } \\
\text { and Dropout Rates at Secondary Level } \\
(\%)\end{array}$} \\
\hline \multirow[b]{2}{*}{ Year } & \multicolumn{2}{|c|}{$\begin{array}{c}\text { Gross } \\
\text { Enrollment }\end{array}$} & \multicolumn{2}{|c|}{ Completion } & \multicolumn{2}{|c|}{ Dropout Rate } \\
\hline & Boys & Girls & Boys & Girls & Boys & Girls \\
\hline 2004 & 48.41 & 39.58 & 13.79 & 20.12 & 86.21 & 79.88 \\
\hline 2005 & 47.17 & 48.62 & 16.71 & 23.46 & 83.29 & 76.54 \\
\hline 2010 & 39.64 & 49.44 & 39.47 & 46.17 & 60.53 & 53.83 \\
\hline 2011 & 43.44 & 51.96 & 47.78 & 40.16 & 52.22 & 59.84 \\
\hline 2012 & 45.70 & 56.63 & 59.56 & 48.17 & 40.44 & 51.83 \\
\hline 2014 & 62.94 & 75.88 & 65.98 & 51.62 & 34.02 & 48.38 \\
\hline 2015 & 67.75 & 77.84 & 66.28 & 54.08 & 33.72 & 45.92 \\
\hline \multicolumn{7}{|c|}{$\begin{array}{l}\text { Source: Government of Bangladesh, Bangladesh Bureau of Educational } \\
\text { Information and Statistics. 2015. Bangladesh Education Statistics. Dhaka. }\end{array}$} \\
\hline
\end{tabular}


Table 17: Secondary Cycle Completion Rate, Dropout Rate, and Coefficient of Efficiency by Sex in Secondary Schools, 2014

(\%)

\begin{tabular}{|l|l|l|l|l|}
\hline Sl. No. & \multicolumn{1}{|c|}{ Indicators } & Both & Boys & Girls \\
\hline 1. & Completion rate $^{\mathrm{a}}$ & 58.06 & 65.98 & 51.62 \\
\hline 2. & Dropout rate $^{\mathrm{b}}$ & 41.94 & 34.02 & 48.38 \\
\hline 3. & Survival rate $^{\mathrm{c}}$ & 63.83 & 72.06 & 57.10 \\
\hline 4. & $\begin{array}{l}\text { Coefficient of internal } \\
\text { efficiency }\end{array}$ & 70.30 & 75.90 & 65.30 \\
\hline
\end{tabular}

${ }^{a}$ Completion rate is the percentage of students completing the last year of primary school. It is calculated by taking the total number of students in the last grade of primary school, minus the number of repeaters in that grade, divided by the total number of children of official graduation age.

Dropout rate is based on the number of students who leave school for any reason before graduation or before completion of a program without transferring to another elementary or secondary school.

c Survival rate is percentage of a cohort of pupils (or students) enrolled in the first grade of a given level or cycle of education in a given school year who are expected to reach successive grades.

d Coefficient of internal efficiency is the ideal (optimal) number of pupil-years required (i.e., in the absence of repetition and dropout) to produce a number of graduates from a given school-cohort for a cycle or level of education expressed as a percentage of the actual number of pupil-years spent to produce the same number of graduates.

Source: Bureau of Educational Information and Statistics. 2014. Bangladesh Education Statistics. Government of Bangladesh, Bangladesh. Dhaka.

\begin{tabular}{|c|c|c|c|c|c|c|}
\hline \multirow[b]{2}{*}{ Year } & \multicolumn{3}{|c|}{ Number of Teachers } & \multicolumn{3}{|c|}{ Enrollment } \\
\hline & Total & Female & $\begin{array}{c}\% \text { of } \\
\text { Female }\end{array}$ & Total & Girls & $\begin{array}{l}\text { \% of } \\
\text { Girls }\end{array}$ \\
\hline 2011 & 223,555 & 52,001 & 23.26 & $7,510,218$ & $4,026,374$ & 53.61 \\
\hline 2012 & 221,043 & 53,862 & 24.37 & $7,937,235$ & $4,229,292$ & 53.28 \\
\hline 2013 & 229,575 & 55,846 & 24.33 & $8,501,442$ & $4,519,091$ & 53.16 \\
\hline 2014 & 232,994 & 58,969 & 25.31 & $9,160,365$ & $4,875,084$ & 53.22 \\
\hline 2015 & 243,117 & 61,701 & 25.38 & $9,743,072$ & $5,193,962$ & 53.31 \\
\hline
\end{tabular}

Source: Government of Bangladesh, Bangladesh Bureau of Educational Information and Statistics. 2015. School Education 2015. Dhaka.

There is a disparity in the number of female and male teachers at secondary level. The number of female teachers as shown in Table 18 was steady at one-fourth of the number of male teachers from 2011 to 2015. There is a general dearth of qualified and experienced teachers for secondary schools, and female teachers are not entering fast enough to fill this gap. This has implications on the performance and retention of girls in secondary schools.
There are multiple reasons for lesser participation of women teachers in secondary schools. The Teaching Quality Improvement (TQI) Project which had sector-wide experience in dealing with the quality of education, provided insights into the issue of low number of female teachers. ${ }^{172}$ It identified this issue as a contributory factor to the poor performance of girls in schools. According to the TQI Project's gender analysis, factors preventing women from taking up teaching jobs were (i) social hindrance; (ii) tradition of male employment; (iii) lack of safe and decent accommodation; and (iv) lack of school facilities suitable for women, e.g., lack of separate toilet facilities, and lack of separate sitting area. The recruitment practices of school management committees (SMCs) were also described as hindering women's employment in teaching as SMCs require the potential teacher to make a donation to the school. ${ }^{173}$

Secondary school systems are usually run by the community; the state has little influence in ensuring gender parity of teachers. However, since the government is providing salaries for the teachers and providing additional support for school infrastructure development, it is gradually exerting a lot more influence over the secondary schools.

The Ministry of Education's budget allocations for women and girls is insufficient. The budget allocation of the MOE for women and girls in the secondary and tertiary levels is below one-third, according to the gender-responsive budget analysis of the Ministry of Finance. The report looks at the number of women staff as well as the Ministry's estimates of how much of its expenditure is for poverty reduction and gender mainstreaming programs within the MOE. ${ }^{174}$ It helps

\footnotetext{
172 ADB. 2012. Second Teaching Quality Improvement in Secondary Education Project. Manila (Project 40448-013-BAN).

173 ADB. 2004. Report and Recommendation of the President to the Board of Directors: Proposed Loan to the People's Republic of Bangladesh for the Teaching Quality Improvement In Secondary Education Project. Manila. (Project 26061 BAN).

174 Government of Bangladesh, Ministry of Finance. 2012. Gender Budgeting Report 2011-2012. Dhaka. https://mof.gov.bd/en/budget/11_12/genbudget/ gender_english.pdf
} 
demonstrate the ways in which social institutions that are seemingly genderneutral do in fact bear and transmit gender biases. Gender budget analyses can be applied to gender-specific expenditures, expenditures that promote gender equity within the public service, and general or mainstream expenditures. The conclusion made by the gender-responsive budget analysis is not only based on per capita allocation of budget for boys and girls, but also on reasons that marginalize girls and the additional budget needed to take necessary steps to overcome them.

\section{- Participation of Girls in Technical and Vocational Training}

Girls are underrepresented in technical and vocational training. In 2012, there were 3,327 technical and vocational education institutes in the country, and $27 \%$ of enrolled students were females (Table 19). About one-fifth of teachers in these institutes were women, and the female share of teachers was relatively higher in the SSC and HSC vocational schools. Girls, too, were most likely to enroll in SSC and HSC vocational schools (68\%) followed by polytechnic institutes or technical school/colleges (17.5\%). The female enrollment share in these schools was around one third, while female enrollment shares were around one fifth in the polytechnic and technical schools and centers and about one fourth in the textile and agriculture training institutes.

Social and cultural stereotypes on suitable occupations for boys and girls, women and men result in occupational segregation. Women and girls are excluded from certain trades and occupations and encouraged into others that are often of lower value, less productive, and low income. Vocational training institutes and programs have a few trades and training programs that are considered to be suitable for girls, like sewing, tailoring, computer

Table 19: Female Enrollment in Technical and Vocational Education Institutions, 2012

\begin{tabular}{|c|c|c|c|c|c|c|}
\hline \multirow[b]{2}{*}{ Type of Institution } & \multirow[t]{2}{*}{ Number } & \multicolumn{2}{|c|}{ Teacher } & \multicolumn{3}{|c|}{ Enrollment } \\
\hline & & Number & $\%$ Female & Number & $\%$ Female & $\begin{array}{c}\text { \% Female } \\
\text { Enrollment } \\
\text { in TVEIs }\end{array}$ \\
\hline Polytechnic institute & 218 & 4,452 & 14.82 & 136,962 & 10.79 & 8.90 \\
\hline Technical school and college & 167 & 2,813 & 16.32 & 64,236 & 22.12 & 8.60 \\
\hline Glass and ceramic institute & 1 & 21 & 19.05 & 1,018 & 6.09 & 0.04 \\
\hline Graphic arts institute & 1 & 14 & 28.57 & 682 & 7.04 & 0.03 \\
\hline Survey institute & 4 & 54 & 9.26 & 1,241 & 5.16 & 0.04 \\
\hline Technical training center & 81 & 1,292 & 16.41 & 25,960 & 33.44 & 5.24 \\
\hline Textile institute & 33 & 513 & 16.18 & 10,009 & 7.78 & 0.47 \\
\hline Textile vocational & 50 & 340 & 17.94 & 5,510 & 23.77 & 0.79 \\
\hline Agriculture training institute & 109 & 953 & 19.10 & 28,890 & 23.96 & 4.18 \\
\hline Marine technology & 1 & 50 & 8.00 & 915 & 11.48 & 0.06 \\
\hline SSC vocational (independent) & 169 & 1,976 & 20.19 & 24,426 & 27.77 & 4.10 \\
\hline SSC vocational (attached) & 1,254 & 6,216 & 23.26 & 114,227 & 35.34 & 24.40 \\
\hline HSC vocational (independent) & 576 & 5,295 & 21.61 & 105,303 & 34.45 & 21.93 \\
\hline HSC vocational (attached) & 663 & 2,333 & 20.53 & 88,797 & 39.51 & 21.20 \\
\hline Total & 3,327 & 26,322 & 19.53 & 608,176 & 27.21 & 99.98 \\
\hline $\begin{array}{l}\text { HSC = higher secondary certificate, } \\
\text { Voc = vocational. } \\
\text { Note: Percentages does not total } 100 \\
\text { Source: Government of Bangladesh, } \\
\text { Bangladesh 2012. Dhaka. }\end{array}$ & $\begin{array}{l}\mathrm{C}=\text { seconda } \\
\text { because of } \mathrm{r} \\
\text { ngladesh } \mathrm{Bu}\end{array}$ & $\begin{array}{l}\text { ool certifica } \\
\text { ing off the de } \\
\text { of Educatior }\end{array}$ & $\begin{array}{l}\text { VEI = techni } \\
\text { als. } \\
\text { nformation as }\end{array}$ & $\begin{array}{l}\text { nd vocationa } \\
\text { atistics. } 2013\end{array}$ & $\begin{array}{l}\text { 1cation institu } \\
\text { tistical Pocket }\end{array}$ & \\
\hline
\end{tabular}


operation, and more recently electronics. Boys are encouraged into mechanics, welding, electrical repair and maintenance, and machine operation, which have high demand. A few trades are emerging as gender-neutral, e.g., mobile repairs, agroprocessing such as mushroom cultivation and processing, and computer repairs. However, the streaming of girls into certain skills results in their being directed to certain occupations, leading to sex-specific occupational segregation, along with its gender discrimination in terms and conditions as well as pay.

\section{- Participation of Women in Tertiary Education}

The number of female students and teachers in tertiary education is slowly increasing but more in certain subjects than others. The number of female students presently ranges from $22 \%$ to $36 \%$ for both private and public universities, and has grown from $22 \%$ to $24 \%$ in 2004 . It is interesting that there are more female students in public universities and more women teachers in private universities.
Table 20 shows that the percentages of female teachers in both private and public universities generally fall within the range of $14 \%-18 \%$. However, in 2009 there was a sudden surge of female teachers in private universities to $30 \%$.

Women's participation has traditionally been less in the technical and scientific fields except for medicine. For example, in case of Bangladesh University of Engineering and Technoogy (BUET), one of the top-rated engineering universities in Bangladesh, the ratio of women to men disproportionately favors men both in the number of teachers and students (Table 21).

However, as shown in Table 22, women's participation is much higher in medicine than in engineering courses, ranging from $34 \%$ to $50 \%$, in both private and public universities. In public medical colleges, the participation of women has remained steady at $40 \%$. In private medical colleges, it reached $50 \%$ in 2012 , after which there is no data. The participation of women teachers, however, remains low for both public and private medical colleges.

\begin{tabular}{|c|c|c|c|c|c|c|c|c|c|}
\hline \multirow[b]{2}{*}{ Year } & \multirow[b]{2}{*}{$\begin{array}{c}\text { Type of } \\
\text { Universities }\end{array}$} & \multicolumn{4}{|c|}{ Teachers } & \multicolumn{4}{|c|}{ Students } \\
\hline & & Total & Women & Men & $\begin{array}{c}\% \text { of } \\
\text { Women }\end{array}$ & Total & Girls & Boys & $\%$ of Girls \\
\hline \multirow[b]{2}{*}{2004} & Public & 6,462 & 975 & 5,487 & 15.08 & 112,327 & 27,953 & 84,374 & 24.80 \\
\hline & Private & 4,815 & 798 & 4,017 & 16.57 & 62,856 & 14,329 & 48,527 & 22.80 \\
\hline \multirow[b]{2}{*}{2005} & Public & 6,921 & 1,085 & 5,836 & 15.67 & 116,397 & 29,475 & 86,922 & 25.30 \\
\hline & Private & 5,638 & 798 & 4,840 & 14.15 & 88,669 & 20,621 & 68,048 & 23.20 \\
\hline \multirow[b]{2}{*}{2009} & Public & 9,163 & 1,656 & 6,507 & 18.07 & 262,941 & 81,988 & 180,953 & 31.18 \\
\hline & Private & 5,710 & 1,701 & 4,009 & 29.79 & 200,939 & 49,125 & 151,814 & 24.45 \\
\hline \multirow[b]{2}{*}{2011} & Public & 9,634 & 1,784 & 7,850 & 18.52 & 182,317 & 53,050 & 129,267 & 29.10 \\
\hline & Private & 6,204 & 1,889 & 4,315 & 30.45 & 257,089 & 66,253 & 190,836 & 25.77 \\
\hline \multirow[b]{2}{*}{2012} & Public & 9,962 & 1,931 & 8,031 & 19.38 & 316,331 & 108,377 & 207,954 & 34.26 \\
\hline & Private & 10,683 & 2,784 & 7,899 & 26.06 & 280,822 & 70,977 & 209,845 & 25.27 \\
\hline \multirow[b]{2}{*}{2013} & Public & 11,252 & 1,308 & 9,944 & 11.26 & 439,549 & 160,215 & 279,334 & 36.45 \\
\hline & Private & 11,882 & 1,707 & 10,175 & 14.40 & 372,653 & 104,669 & 267,984 & 28.08 \\
\hline \multirow[b]{2}{*}{2014} & Public & 11,505 & 2,377 & 9,128 & 20.66 & 454,530 & 168,499 & 286,031 & 37.07 \\
\hline & Private & 12,522 & 3,684 & 8,838 & 29.42 & 399,182 & 106,629 & 292,553 & 26.71 \\
\hline \multirow[b]{2}{*}{2015} & Public & 12,414 & 2,721 & 9,693 & 21.92 & 493,110 & 181,450 & 311,660 & 36.80 \\
\hline & Private & 13,905 & 3,983 & 9,922 & 28.64 & 379,781 & 105,275 & 274,506 & 27.72 \\
\hline
\end{tabular}


Women's leadership presence in tertiary education is still insignificant. Women's leadership presence would ensure the participation of women in decision-making, make the institutions friendlier to girls and women, and provide role models to both girl students and women teachers. The absence of structured interventions to develop women's leadership in tertiary education has been reported by Manfredi, ${ }^{175}$ and was further endorsed by a former University Grants Commission (UGC) chairman. ${ }^{176}$ Successful senior women faculty felt that they had to seek out their own development often overseas, as there were no formal mentoring arrangements, very few development programs, and no structured capacity building or career advice. Studies of academic cultures and reports on the interviews done for the Manfredi study point to the traditionally male-dominated nature of higher education institutions. The overall academic environment, therefore, is not woman-friendly. There is strong evidence of gender discrimination against women and gender-based violence in higher education campuses. Gender discrimination is, however, worse in administrative and managerial positions. As a result, most women academics preferred their academic career dealing with teaching and students (over which they have more control), rather than the school's administrative and managerial positions. ${ }^{177}$

Lack of women in senior posts in education limits their potential to make their institutions more gender responsive and to function as role models for girls and women. The traditional roles of women still create serious constraints on their path toward professional growth. As mentioned during the regional consultations conducted in preparation of the GED, a female professor stated that many of her female colleagues do not accept promotions so that they would not

\footnotetext{
${ }^{175}$ S. Manfredi et al. 2014. Gender and Higher Education Leadership: Researching the Careers of Top Management Programme Alumni. London: Leadership Foundation for Higher Education.

${ }^{176}$ Interview with former University Grants Commission (UGC) chair. Personal Interview. Dhaka 2016

177 Footnote 175 (Gender and Higher Education Leadership).
}

Table 21: Number of Teachers and Students in Bangladesh University of Engineering and Technology by Sex

\begin{tabular}{|c|c|c|c|c|c|c|}
\hline \multirow[b]{2}{*}{ Year } & \multicolumn{3}{|c|}{ Teachers } & \multicolumn{3}{|c|}{ Students } \\
\hline & Women & Men & $\begin{array}{l}\text { Ratio of } \\
\text { Women } \\
\text { to Men }\end{array}$ & Girls & Boys & $\begin{array}{c}\text { Ratio of } \\
\text { Girls to } \\
\text { Boys }\end{array}$ \\
\hline 2000 & 57 & 443 & 12.9 & 945 & 6,270 & 15.1 \\
\hline 2002 & 65 & 414 & 15.7 & 1,137 & 6,456 & 17.6 \\
\hline 2009 & 100 & 478 & 20.9 & 1,455 & 6,088 & 23.9 \\
\hline 2010 & 128 & 521 & 24.6 & 1,468 & 6,199 & 23.7 \\
\hline 2011 & 0 & 649 & 0.0 & $\begin{array}{l}\text { Data not } \\
\text { available }\end{array}$ & $\begin{array}{l}\text { Data not } \\
\text { available }\end{array}$ & $\begin{array}{l}\text { Data not } \\
\text { available }\end{array}$ \\
\hline 2012 & 124 & 495 & 20.0 & $\begin{array}{l}\text { Data not } \\
\text { available }\end{array}$ & $\begin{array}{l}\text { Data not } \\
\text { available }\end{array}$ & $\begin{array}{l}\text { Data not } \\
\text { available }\end{array}$ \\
\hline 2013 & 124 & 495 & 20.0 & $\begin{array}{l}\text { Data not } \\
\text { available }\end{array}$ & $\begin{array}{l}\text { Data not } \\
\text { available }\end{array}$ & $\begin{array}{l}\text { Data not } \\
\text { available }\end{array}$ \\
\hline
\end{tabular}

Source: Bangladesh Bureau of Educational Information and Statistics. 2014. Bangladesh Education Statistics. Government of Bangladesh. Dhaka.

be transferred; the rules make it obligatory for all those promoted to be transferred to a different location. Providing secure residential benefits for female teachers can work as a motivational factor for accepting promotions.

The significant rise of the private sector in the provision of university education (including women-only institutions) is providing opportunities for women's participation and leadership. This is because culturally women are not encouraged to study in coeducational situations. The preference for sexsegregated education in some contexts means that some single-sex higher education institutions are being developed. These create some opportunities for women to enter leadership positions, as the top positions in these universities mostly belong to women. For example, the Asian University for Women in Bangladesh and Central Women's University (both womenonly universities) have female vicechancellors (Box 14).

\section{- Skilled Migration Opportunities for Women}

Skills development is important so that migrant women who are unskilled and uneducated, therefore underpaid and exploited, can diversify their 


\begin{tabular}{|c|c|c|c|c|c|c|c|c|c|}
\hline \multirow[b]{2}{*}{ Year } & \multirow{2}{*}{$\begin{array}{l}\text { Type of } \\
\text { Medical } \\
\text { College }\end{array}$} & \multicolumn{4}{|c|}{ Teachers } & \multicolumn{4}{|c|}{ Students } \\
\hline & & Total & Women & Men & $\begin{array}{c}\% \text { of } \\
\text { Women }\end{array}$ & Total & Girls & Boys & $\%$ of Girls \\
\hline \multirow[b]{2}{*}{2004} & Public & 1,215 & 240 & 975 & 19.75 & 11,602 & 4,675 & 6,927 & 40.29 \\
\hline & Private & 740 & 123 & 617 & 16.62 & 4,992 & 2,195 & 2,797 & 43.97 \\
\hline \multirow[b]{2}{*}{2005} & Public & 1,218 & 240 & 970 & 19.70 & 11,731 & 4,692 & 7,039 & 40.00 \\
\hline & Private & 1,037 & 123 & 914 & 11.86 & 6,954 & 2,384 & 4,570 & 34.28 \\
\hline \multirow[b]{2}{*}{2010} & Public & 1,312 & 244 & 968 & 18.60 & 11,736 & 4,704 & 7,032 & 40.08 \\
\hline & Private & 1,202 & 123 & 1,079 & 10.23 & 7,660 & 2,623 & 5,037 & 34.24 \\
\hline \multirow[b]{2}{*}{2011} & Public & 1,332 & 246 & 1,086 & 18.47 & 14,035 & 5,646 & 8,389 & 40.23 \\
\hline & Private & 1,406 & 186 & 1,220 & 13.23 & 12,845 & 5,642 & 7,203 & 41.99 \\
\hline \multirow[b]{2}{*}{2012} & Public & 1,362 & 254 & 1,108 & 18.65 & 14,060 & 5,654 & 8,406 & 40.21 \\
\hline & Private & 1,432 & 190 & 1,242 & 13.27 & 15,666 & 6,884 & 8,782 & 49.94 \\
\hline \multirow[b]{2}{*}{2013} & Public & 3,342 & 622 & 2,720 & 18.61 & $\begin{array}{l}\text { Data not } \\
\text { available }\end{array}$ & $\begin{array}{l}\text { Data not } \\
\text { available }\end{array}$ & $\begin{array}{l}\text { Data not } \\
\text { available }\end{array}$ & $\begin{array}{l}\text { Data not } \\
\text { available }\end{array}$ \\
\hline & Private & 1,562 & 190 & 1,372 & 12.16 & $\begin{array}{l}\text { Data not } \\
\text { available }\end{array}$ & $\begin{array}{l}\text { Data not } \\
\text { available }\end{array}$ & $\begin{array}{l}\text { Data not } \\
\text { available }\end{array}$ & $\begin{array}{l}\text { Data not } \\
\text { available }\end{array}$ \\
\hline \multirow[b]{2}{*}{2014} & Public & 3,342 & 622 & 2,720 & 18.61 & $\begin{array}{l}\text { Data not } \\
\text { available }\end{array}$ & $\begin{array}{l}\text { Data not } \\
\text { available }\end{array}$ & $\begin{array}{l}\text { Data not } \\
\text { available }\end{array}$ & $\begin{array}{l}\text { Data not } \\
\text { available }\end{array}$ \\
\hline & Private & 1,562 & 190 & 1,372 & 12.16 & $\begin{array}{l}\text { Data not } \\
\text { available }\end{array}$ & $\begin{array}{l}\text { Data not } \\
\text { available }\end{array}$ & $\begin{array}{l}\text { Data not } \\
\text { available }\end{array}$ & $\begin{array}{l}\text { Data not } \\
\text { available }\end{array}$ \\
\hline \multirow[b]{2}{*}{2015} & Public & 3,345 & 624 & 2,721 & 18.65 & $\begin{array}{l}\text { Data not } \\
\text { available }\end{array}$ & $\begin{array}{l}\text { Data not } \\
\text { available }\end{array}$ & $\begin{array}{l}\text { Data not } \\
\text { available }\end{array}$ & $\begin{array}{l}\text { Data not } \\
\text { available }\end{array}$ \\
\hline & Private & 1,574 & 194 & 1,380 & 12.33 & $\begin{array}{l}\text { Data not } \\
\text { available }\end{array}$ & $\begin{array}{l}\text { Data not } \\
\text { available }\end{array}$ & $\begin{array}{l}\text { Data not } \\
\text { available }\end{array}$ & $\begin{array}{l}\text { Data not } \\
\text { available }\end{array}$ \\
\hline
\end{tabular}

employment to higher category jobs with better conditions. Migration is an important route for employment for men and increasingly for women as well. Of the households covered by the Household Income and Expenditure Survey, 12.28\% reported any kind of migration either within the country or abroad; of these, $8.60 \%$ of the households reported migration abroad. ${ }^{178}$ Migration is included in this discussion because many women migrating overseas for work are uneducated and unskilled, making them more vulnerable to exploitation. An important factor that can mitigate this problem is education and skills development.

\footnotetext{
${ }^{178}$ Government of Bangladesh, Bangladesh Bureau of Statistics. 2011. Household Income Expenditure Survey 2010. Dhaka.
}

Women's migration is socially and economically significant. Female international migration started in the late 1990 s, when women were only $1.49 \%$ of the total international migrants. Although the the total size of international migration is decreasing, female international migration trends are increasing in terms of percentage and numbers. About $13 \%$ of international migrants are women. ${ }^{179}$ Only $3 \%$ of migrants work in professional categories, and women mainly migrate as housemaids, cleaners, caregivers. ${ }^{180}$ Women's proportionate contribution to remittances is more than

\footnotetext{
${ }^{179}$ As per Bureau of Manpower, Employment and Training (BMET) reports, female international migrants were 158,862 out of total international migrants 2,350,429 during 2009-2013.

180 Government of Bangladesh, Ministry of Labour and Employment. 2011. Migration from Bangladesh and overseas employment policy-BMET. Dhaka.
} 
their male counterparts because they remit on average $72 \%$ of their income home against $45 \%-50 \%$ of income sent by men. Despite the low proportion of female migrants, their per capita contribution has major impact on their respective families. ${ }^{181}$

Currently, government regulations restrict women migrants to certain categories of employment that are low skilled and low paid. In parallel to reforming these regulations, initiatives are needed to prepare women for more skilled employment categories that would provide better working conditions and higher earnings. More diversified technical and vocational education that would prepare women for better skilled jobs with the necessary life skills (language, communications, labor laws, emigration procedures, remitting money securely) is needed so that they can respond to new openings in international markets. The International Organization for Migration and UN Women have taken various initiatives in this regard.

According to the Bureau of Manpower, Employment, and Training (BMET), demand for Bangladeshi female workers is increasing significantly in traditional and new markets. As of end 2015, more than 50,000 women registered online for jobs abroad. ${ }^{182}$ The government has placed some recommendations to the labor-receiving countries, including increased salaries and weekly leave facilities for female migrant workers. However, there is a need to help negotiate their entry into higher skilled and better paid employment.

\section{- Skills Development for Women's Entrepreneurship}

Another area where vocational education and skills development can make a difference for women is their involvement in enterprise development. Wage employment is only one of the

\footnotetext{
181 "Remittance of the female migrant workers is usually for the repayment of family loan (32.61\%), followed by family consumption (31.52\%) and investment in small businesses or buying agricultural land (26.09\%).” U.K. Das. 2012. Female Migrant Workers' Remittances and Contribution to the National Economy: An Exploratory Research. http://bomsa.net/Report/R1001.pdf

${ }^{182}$ Interview with the director general of BMET.
}

\section{Box 14: Women-Only Universities}

Asian University for Women. The idea grew out of the World Bank and United Nations Task Force on Higher Education and Society. In 2000, the task force published its findings in a report entitled "Higher Education in Developing Countries: Peril and Promise" (http://www .tfhe.net/), concluding that developing countries must improve the quality of their institutions of higher learning, in both governance and pedagogy, to compete in today's increasingly globalized, knowledgebased economy. The university is home to many international students mainly from Asia such as Afghanistan, Bangladesh, Bhutan, Cambodia, the People's Republic of China, India, Indonesia, Malaysia, Nepal, Pakistan, Palestine, Sri Lanka, Syria, and Viet Nam.

Central Women's University. It is the only women's university in Dhaka that began its journey in 1993 immediately after the passing of the Private University Act of 1992. The university was established with a group of educationalists led by Professor Beggzadi Mahmuda Nasir (founder and vice-chancellor of the university). Their intention was to create an opportunity for women to pursue higher education and to equip themselves with necessary knowledge and skills for gainful employment in the age of globalization. The university is in a conservative area where female education is not encouraged. The establishment of this university has helped local girls who would have otherwise not entered higher education.

Source: Author.

possible avenues for women. Enterprise development has always been an option, but it is now increasingly regarded as a viable and legitimate possibility for gainful employment. This can range from smallscale home-based income generation to formal large-scale businesses and firms with a considerable workforce and commensurate financial capital owned and managed by women. However, the presence of women in small and medium-sized enterprises (SMEs) is still very low, and even lower in large enterprises. They face obstacles including limited access to finance, markets, business networks, and training, as well as the double burden of raising a family and running a business. Of particular importance is the need for various entrepreneurial skills such as communications, management, business financing, and technical skills related to the sector (e.g., food processing and preservation) (Box 15). 


\section{Box 15: Training of Women Entrepreneurs}

A study on women entrepreneurs in small and medium-sized enterprises conducted by Midas in 2009 found that $53.7 \%$ of the respondents had received training before business, $19.5 \%$ had received training during business, and $26.7 \%$ had not received any training. Majority of the respondents (34.8\%) said that the cost was borne by development partners, $32 \%$ by themselves, $2.9 \%$ by nongovernment organizations, $10.9 \%$ by their husbands, and $9.4 \%$ by their families. ${ }^{a}$

${ }^{\text {a }}$ The report does not specify the remaining $10 \%$.

Source: Micro Industries Development Assistance and Services. 2009. Women Entrepreneurs in SMEs: Bangladesh Perspective.

\section{Box 16: Beijing Platform for Action on Vocational Education}

The 1995 Beijing Platform for Action had highlighted the importance of vocational and continuing education. Strategic objective B.3. was to "Improve women's access to vocational training, science and technology, and continuing education.” Strategic objective B.4. was to "Develop nondiscriminatory education and training." Strategic objective B.5. was to "Allocate sufficient resources for and monitor the implementation of educational reforms.” Strategic objective B.6. was to "Promote life-long education and training for girls and women."

Source: United Nations Entity for Gender Equality and the Empowerment of Women. 1995. Platform for Action. The United Nations Fourth World Conference on Women. Beijing. September.

\section{Policy and Institutional Context for Addressing Gender Inequality}

\section{- International Commitments}

The policy directions on general and vocational education provided by the Beijing Platform for Action (Box 16) remain relevant and have not been fully translated into national policies and programs, and therefore are still aspirational. In addition, the Sustainable Development Goal (SDG) Goal 4 is to "Ensure inclusive and equitable quality education and promote lifelong learning opportunities for all." Targets include "By 2030, ensure equal access for all women and men to affordable and quality technical, vocational and tertiary education, including university."

\section{- National Policies on Education and Their Gender Features}

National educational policies presented here are the National Education Policy 2010, National Skills Development Policy (NSDP) 2011, National Skills Development Council (NSDC), Non-Formal Education
Policy 2006, technical and vocational education and training (TVET), draft National Strategy for Promotion of Gender Equality in TVET 2012, skills development strategy in the Seventh Five Year Plan, Industrial Policy 2010, National Action Plan for Women's Advancement, and the National Strategic Plan for Higher Education (2016-2026).

The National Education Policy is allencompassing, while the rest of the policies are directly related to skills and vocational subsectors. However, the study of the policies and consultations with practitioners suggest that gender considerations have not been included comprehensively. It appears that these policies have scope for greater promotion of gender equality. For instance, in the NSDP, limited emphasis is given to engaging women in nontraditional, marketable vocational activities. It is addressed in the Draft National Strategy for Promotion of Gender Equality in TVET, but the policy is still only a draft. In addition, the NSDP does not give appropriate importance to women entrepreneurship, which is set out in the Industrial Policy 2010.

Policies require more attention to the creation of information and motivation for women on employment opportunities so that they can understand the relevance of vocational, skills, or technical education. Since many women are not adequately familiar with the market and not expecting to be allowed or encouraged to work, they are less inclined to avail themselves of educational opportunities that link them to sustainable gainful livelihoods. Empowering women through skills development, vocational education, and tertiary education will require provision of exposure to new opportunities and creating motivation for them to engage in the world of work. The education policy documents generally say little about the processes that are supposed to integrate women effectively into the workforce.

Greater coordination with the private sector and interagency coordination is promoted by policy. The NSDP emphasizes the imperative to improve the supply of human resources with necessary skills and attitudes to meet the industry demand for 
skilled workers. The NSDP has provided guidance for constructing a road map. The policy also extends to and builds on other major government education policies, such as the Nonformal Education Policy 2006, Youth Policy 2008, and NSDC Action Plan. Institutional actions are now being directed toward the implementation of NSDP. One of the important dimensions of this development is the emphasis on the publicprivate partnership (PPP). In this regard, industry skills councils have been formed, some of which have been receiving technical assistance (TA) from the International Labour Organization (ILO). ILO has been also providing technical support to the NSDC (Box 17) regarding TVET governance, including standardization of TVET delivery.

Other agencies are being strengthened by National Skills Development Council for the provision of technical skills. The types of skills provided on livelihood activities are mainly gender stereotypes and traditionally associated with women, such as poultry raising, embroidery, and nursery. To cope with the growing skills needs of the population, the government has also given permission for establishing registered training organizations, where the private sector can participate through for-profit skills delivery.

An ongoing Technical and Vocational Education and Training Reform Project assisted by the ILO and funded by the European Union, and the completed ADBsupported Skills Development Project have supported significant reforms on many fronts including quality assurance arrangements and gender equality. The National Technical and Vocational Qualifications Framework (NTVQF) and the National Skills Quality Assurance System have been established along with regulations and manuals as recommended by NSDP. These developments reflect changes within the skills production system that are necessary to meet the industry demand of the supply of skilled workers. While the NSDP promotes gender equality, it does not give enough guidance toward achieving gender equality in TVET. In response to this need, the draft National Strategy for Promotion of Gender Equality was

\section{Box 17: National Skills Development Council}

The National Skills Development Council (NSDC) was established to implement the Skills Development Policy. ${ }^{a}$ The NSDC is chaired by the Prime Minister with the power to direct, coordinate, supervise, develop, and recommend initiatives and policies relating to skills development. It brings together representatives from the government, development partners, nongovernment organizations, and private sectors. Despite constraints NSDC has made progress. A substantial portion of its action plan has been implemented. For instance, it has achieved several milestones in institutional delivery, i.e., creation of 15 industry skills councils, and major government line ministries have made moves to change curricula, etc. National advocacy and social mobilization has resulted in $20 \%$ increase of women's participation in vocational education. Similar progress has been made in developing National Technical and Vocational Qualifications Framework.

The Skills Development Policy proposed the transformation of the institutional arrangement to ensure effective and efficient implementation of skills development mandate. There were two major deficiencies in the previous skills development delivery system. First, there was no central agency to coordinate skills development, since skills development was considered synonymous with vocational and technical education. Second, existing vocational and technical skills training were not geared toward a demand-driven market economy. The NSDC was therefore set up.

Source: United Nations Educational, Scientific and Cultural Organization (UNESCO). 2010. Gender Issues in Higher Education. Bangkok: UNESCO Asia and Pacific Regional Bureau for Education.

elaborated with a TA from ILO to support and complement the NSDP in a meaningful manner. Similarly, the national Nonformal Education Policy Framework and other documents support and complement each other in creating a demand-driven, marketoriented, empowering education system for all, which can enable women to enter economic realms that were formerly not open to them.

The TVET Reform Project includes the following:

- Draft National Strategy for Promotion of Gender Equality in TVET 2012.

- Introduction of technical and vocational courses in secondary, higher secondary, and madrasa levels.

- Introduction of double shift in the existing technical schools and colleges and polytechnic institutes.

- Recognition of prior learning.

- Improved access for underrepresented groups.

- Industry training and workforce development. 
Draft National Strategy for Promotion of Gender Equality in Technical and Vocational Education and Training 2012 supplements the other strategies and helps focus attention on critical gender issues and actions to be taken. The specific objectives of the strategy are as follows:

(i) Increase female participation in formal TVET institutions by $16 \%$ from the present $24 \%$ to $40 \%$ by 2020.

(ii) Increase female employment by at least $30 \%$.

(iii) Increase quotas for female teachers $(30 \%)$ and female staff $(20 \%)$.

(iv) Quotas for females in TVET management should be at least $10 \%$.

(v) Enhance positive attitudinal shifts in views regarding female trades and employment.

(vi) Ensure gender-friendly environment in education and training institutions and workplaces.

(vii) Create linkages between industry demand and supply for skills.

(viii) Establish extensive genderresponsive support systems and counseling services.

(ix) Accommodate skill training for workers in the informal economy also.

(x) Establish adequate data management systems to capture sexdisaggregated data on TVET.

The skills development strategy in the Seventh Five Year Plan seeks to continue earlier policies and address gaps, and has a special mention of gender equity. The NSDC provides the following main elements of the skills development strategy: ${ }^{183}$

- Implement the vision and mission of NSDP 2011.

- Produce educated, qualified, and skilled workforce for the accelerated economic development of the country.

- Diversify technical and vocational education programs to meet the technical staffing needs in the information technology and in areas

183 NSDC, ILO, EU. 2012. Draft National Strategy for Promotion of Gender Equality in Technical and Vocational Education and Training (TVET). Dhaka. of emerging technologies such as instrumentation and process control, construction, garments design and pattern making, electro-medical, etc.

- Encourage more women's participation in TVET to ensure empowerment, equality, and gender equity.

- Develop and modernize the existing TVET institutions with available rural technologies to meet the challenge of the fast-changing economy in the rural setting for poverty alleviation and to arrest rural-urban migration.

- Encourage private sector involvement and initiative in the delivery of technical and vocational education programs.

Gender equality measures mentioned in the Seventh Five Year Plan strategy on skills training include the following: ${ }^{184}$

- Female quota for admission into vocational and technical education institutes will be doubled. Studies show that vocational and technical education has higher returns for both males and females compared with HSC education. Although the returns to vocational and technical education have decreased for males, the returns to female students have substantially risen in both urban and rural areas, underlying the need to encourage more females to pursue this field. Accordingly, the government plans to increase the enrollment in technical education from the current $8 \%$ to $25 \%$ within the next 10 years. A target of $40 \%$ female enrollment in TVET by 2020 has been set.

- Stipends and other financial support will be provided to the poor, especially female students, to encourage enrollment, retention, and completion.

- Four new polytechnic institutes exclusively for women have been set up in four divisional headquarters (in Dhaka, Chittagong, Khulna, and Rajshahi). Three additional women's polytechnic institutes will be setup at Barisal, Sylhet, and Rangpur divisional headquarters. Seven women's technical schools and colleges in seven divisions will be established.

${ }^{184}$ Footnote 40 (Seventh Five Year Plan FY2016-2020). 
Skills development for women entrepreneurs is provided under the Industrial Policy 2010 with a revised draft (2016). The draft has a section on promoting women entrepreneurs with positive provisions for women's economic empowerment particularly related to financial inclusion and entrepreneurship. The policy defines industries of different categories and includes provisions for different incentives for industrial undertakings. Generation of productive employment, mainstreaming women in the industrialization process, and poverty alleviation were critical underlying objectives of the Industrial Policy 2010. The policy outlined necessary steps to provide women entrepreneurs with preinvestment advice and assistance in drawing up and implementing projects and with necessary assistance and services by SME Foundation and Bangladesh Small and Cottage Industries Corporation. Arranging technical training in public sector institutions was envisaged for enhancing the efficiency of women entrepreneurs.

The National Action Plan for Women's Advancement 2011 also emphasizes developing women's entrepreneurial skills. This includes upgrading the technical know-how of women workers, and developing technology suitable for women in addition to women's easy access to market, infrastructural facilities, and finances.

Bangladesh has recently developed the National Strategic Plan for Higher Education (2006-2026) for the next 20 years. The strategic plan highlights major challenges facing the sectors in Bangladesh and recommends strategies to address the issues. The strategic plan recognized that, among others, limited access, weak governance and management of institutions, and low quality of higher education are the major issues that need to be addressed. The plan proposed some policy reforms and interventions to be implemented in three consecutive phases. Some of the key recommendations are (i) depoliticization of public universities, (ii) setting up a national search committee for selecting vice-chancellors and other senior officials, (iii) strengthening of University Grants Commission (UGC), (iv) establishment of accreditation council, (v) enhanced support for research, and (vi) development of strategies for retaining and developing quality teaching staff. Although these measures will benefit women in tertiary education who are particularly affected by these problems, gender issues has not been explicitly addressed.

Some gaps remain in the existing policies, such as the following:

(i) The various policies need to adequately recognize or address women's constraints on availing vocational or skills training. Since women aspiring for skills in higher income vocation are already involved in income-generating activities and household work, they find it difficult to remain out of the home for a long time to receive training. In addition, the family also feels insecure about safety away from home. An example given during the regional consultations for this Gender Equality Diagnostic (GED) was that even in NGOoffered training courses on garment's work with a stipend in advance, women were not willing or able to avail of the opportunity.

(ii) The current skills development and vocational and tertiary education policies and interventions need to seriously target the minority and marginalized groups. This is the case specifically in the Chittagong Hill Tracts areas. The people in the Hill Tracts share a different kind of socioeconomic conditions and structure as compared with the main land. Therefore, needs-based interventions in these areas ought to be comprehensively developed. Also, information technology-enabled systems can dramatically reduce cost and time of commuting along with reducing the risk of insecurity for women.

To pursue gender equality and women's empowerment, interventions interfacing between social and institutional issues need to be developed because women face both simultaneously. Secondary, tertiary, 
and skills sectors need to further develop their capacities in providing technical and entrepreneurship skills training opportunities to women and developing the capabilities of women in market-oriented activities.

\section{Overall Good Practices and Lessons}

There are several good practices that have emerged in skills development that can be considered.

\section{- Private sector initiatives through corporate social responsibility}

The A.K. Khan Foundation (AKKF) is a nonprofit and nonpolitical social welfare organization set up by the A.K. Khan Group, an established business and industrial conglomerate, as part of its corporate social responsibility. A.K. Khan Group of companies has earmarked $30 \%$ of its profit for the well-being of the needy community, especially for the improvement of health and education services for the vulnerable groups in society. As leaders in the field of industrialization, the company is active in capacity development and TVET, and works closely with government and the private sector to ensure that supply and demand match. It works at the policy levels, directly provides skills education and support for education through the AKKF. It provides stipends and scholarships to students at different levels. In addition, it has been providing grants to improve institutional capacity of both technical and general educational institutions. Some of the instances of its support are as follows:

- A.K. Khan-UCEP Technical School, Chittagong. At present, there are 716 students in the technical school and 719 students in the general school. The AKKF is supporting a well-established model of TVET set up by Underprivileged Children's Educational Programs (UCEP). The model so far has provided quality education, but has not been able to bring in girls in equal numbers despite measures like transportation for the children. However, recent initiatives include community outreach to parents and children to explain the training options available as well as the future employment options. Targets for the recruitment of girls are also being set.

- AKKF also provided grants to universities, medical colleges, high schools, primary schools, orphanages, nursing training institutes, vocational training programs, and individual students. Half of the individual stipends are given to women to promote science education and studies in medicine. ${ }^{185}$

\section{- Linking vocational education and livelihoods}

Swisscontact, an international NGO, is contributing to vocational skills development through provision of livelihood skills and linkages. This is an approach that goes beyond classroom-based training and education to develop skills in a practical context. It supports economic, social, and ecological development by addressing missing linkages to facilitate women's empowerment in dealing with market mechanisms, such as the procurement of raw materials, transportation to markets, and being able to negotiate with stakeholders independently. One of the initiatives is the Markets for the Char portfolio, which includes agriculture or farming sectors such as maize, chili, jute, onion, groundnut, mustard, and rice in addition to handicrafts as off-farm and char transport system and financial services as cross-cutting sectors. Women are active in these areas and their skills as producers and entrepreneurs are being strengthened through these interventions. The project has implemented several interventions in these sectors since 2012 in partnership with private and public stakeholders.

\section{- Combining basic education with lifelong learning}

NGOs, including Dhaka Ahsania Mission (DAM), Building Resources Across Communities (BRAC), Proshika, Caritas, Swanirvar Bangladesh, and many others launched massive education programs targeting primarily women. An example is the approach taken by DAM. In order to provide an institutional base and a structured post-literacy and continuing

\footnotetext{
${ }^{185}$ For further info, see A.K. Khan \& Company Ltd. www.akkhan.com/csr
} 
education program, DAM established in 1992 a total of 808 ganokendras (people's centers in Bengali or community learning centers [CLCs]) as an innovative approach to basic education and lifelong learning for gender equality along with the provision of livelihood skills. An empirical investigation of this initiative of DAM was undertaken describing good practices used by two CLCs to promote gender equality in basic education and lifelong learning. These good practices included $75 \%$ female membership because of the priority given to the marginalized and illiterate, and importance given to literacy programs and skills development needed by poor women, as well as social awareness raising on, among others, gender issues and health (especially women's health), targeting both women and men. ${ }^{186} \mathrm{~A}$ similar approach was followed by the ADB-supported Post-Literacy and Continuing Education Project. In Bangladesh, particularly in rural areas, women usually find very little time for socialization. They are engaged in household chores, and their opportunity to socialize is constrained by social restriction. Programs like CLCs allow women to socialize, discuss their concerns, and facilitate the possibility of taking initiatives for their collective development. On the other hand, usually men are much less inclined to participate in CLCs since they have diverse options for socialization and interacting for business purposes.

\section{- Exposure and integration of apprentices into the workplace}

The BRAC Skills Training for Advancing Resources (STAR) program was initially conceptualized within the Basic Education for Hard to Reach Urban Working Children implemented by UNICEF and the Government of Bangladesh. The main goal of BRAC model was to provide holistic skills development training and decent employment opportunities to enable young women and men to realize their full potential. Its objectives included (i) providing competency-based skills

\footnotetext{
${ }^{86}$ A. Pant. 2003. Good Practices: Gender Equity in Basic Education and Lifelong Learning through CLCs: Experiences from 15 Countries. Bangkok: UNESCO Asia and the Pacific Regional Bureau for Education.
}

training, following the NTVQF, and soft skills development training to underprivileged youth who have dropped out of school; (ii) ensuring decent job linkage and entrepreneurship development through the creation of a skilled workforce with higher level of awareness and greater job mobility; and (iii) developing the capacity of markets and industries to take on apprentice and providing training following NTVQF in a safe and decent workplace.

Some of the key features of the STAR project are the (i) rigorous market analysis to identify trades in demand, (ii) identification of underprivileged school dropout youth, (iii) primary focus on young women $(50 \%$ female learners), (iv) special attention to person with disabilities, (v) enterprisebased practical training, (vi) classroombased theoretical training, (vii) information and guidance for entrepreneurship development, and (viii) assessment in accordance to NTVQF 4.

The duration of the program is for 6 months (5 days practical training and 1 day theoretical and soft skills training every week). Master crafts persons are local entrepreneurs selected during market analysis and trained by BRAC to provide hands-on training to the apprentices following competency-based training and assessment. Upon completion of training, BRAC supports graduates to undertake assessment exams under NTVQF. Girls are encouraged to take up nontraditional skills such as mobile phone servicing, wood furniture, basic electronics, electrical and house wiring, automobile servicing, and refrigeration and air-condition servicing, while more traditional trades are also offered such as tailoring and dressmaking, embroidery, beautification, and blockbatik. One of the strongest points of the STAR project is an overwhelming majority of girls continuing their work with the local entrepreneurs, especially in the cases of tailoring and beautification trades.

\section{- Mobile information and communication technology training}

The Information and Communication Technology (ICT) Division of the Government of Bangladesh has undertaken a project with public-private partnership (PPP) to provide training in ICT skills to 
young women in remote locations. The announcement of the program describes an innovative approach that enables women to acquire new skills within their own home. ${ }^{187}$

The mobile arrangement is also helpful in providing needs-based training with much higher coverage and less cost. The results are yet to be documented as the project has just started, but the approach itself is worth considering.

\section{- Ending the "gender digital divide" in Egypt}

The Government of Egypt has invested in ICT as it works to build a knowledgebased society and seize opportunities for women's employment and empowerment. As part of an effort to transform the "gender digital divide," the government has initiated a program known as Information and Communication Technology for Elimination of Illiteracy. Its objective is to eradicate illiteracy among 10,000 people every year in 10 of the country's 27 governorates. The program involves collaboration with the nongovernment sector to create educational content on compact discs that trainees can use anywhere. This approach makes training available in remote areas. The interactive computer-based tutorial teaches basic reading and writing skills. The curriculum reflects everyday life using sound and music effects.

Much of the success of the program is due to the introduction of the innovative "tabulator" or computer setup. Built around the concept of a traditional tableya, a low, round table traditionally used for eating in rural Egypt, the tabulator uses a single computer processor that can accommodate

\begin{tabular}{|l|c|c|c|c|c|}
\hline \multicolumn{6}{|c|}{ Table 23: Bangladesh Education Projects by ADB Gender Category } \\
\hline Year Approved & GEN & EGM & SGE & NGE & Total \\
\hline $2009-2012$ & 2 & - & - & & 2 \\
\hline $2013-2015$ & 4 & - & - & & 4 \\
\hline Total & 6 & - & & & 6 \\
\hline
\end{tabular}

$\mathrm{EGM}=$ effective gender mainstreaming, GEN = gender equity theme, $\mathrm{NGE}=$ no gender elements, $\mathrm{SGE}=$ some gender elements.

Source: SARD Gender and Development Database 2016. four independent users, each equipped with his/her own screen, keyboard, mouse, and sound card. This offers rural women an opportunity to learn ICT skills without having to travel far from home. Such an approach serves to overcome community traditions that had prevented women from becoming literate and from learning about technology. State commitment and community participation are also ingredients in the program's success. ${ }^{188}$

\section{Gender Equality in Skills, Vocational, and Tertiary Education: the ADB Experience}

Table 23 shows that all the ADB projects in the education sector approved or completed in 2009-2015 are categorized as gender equity theme (GEN), which means that they directly address gender issues in the education sector and have a big potential of contributing to gender equality and women's empowerment. This section presents the gender-related aspects, challenges, and lessons from some of these ADB-supported projects.

\section{- Secondary Education Subsector}

ADB experience in the secondary education subsector is that gender-related reforms require a long implementation period, persistent pursuit of reform agenda, and continued budgetary support to accomplish targeted improvements. It has also shown that reform is a slow process and requires action at multiple levels, through multiple strategies. For example, a school-based management approach helps to utilize hands-on training support for teachers, new facilities, and equipment provided to schools; and effective school leadership is required to bring significant changes to school management and performance and is critical for leadership to support gender reforms. The Secondary Education Sector Investment Program (Tranche 2), an ongoing investment program (from January 2014 to December

\footnotetext{
188 A.B. Mansson and U. Farnsveden. 2012. Gender and Skills Development: A Review. Background paper for the EFA Global Monitoring Report 2012 Working Paper 4. New York: UN Girls' Education Initiative.
}

187 The Daily Star. 2015. Rural Women to get ICT Training. 9 November. 
2017) categorized as GEN, supports the government's reform of secondary education (grades 6-12) into a system that builds the foundation for a skilled labor force and prepares youth to meet the requirements of a rapidly developing economy. ${ }^{189}$ It supports advanced teaching and learning programs that use ICT as well as prevocational and vocational programs, teacher development, and examination reforms. It promotes gender equitable and pro-poor stipends for students. The program will also support establishing a more decentralized and efficient allocation and use of resources, as well as strengthening sector performance monitoring.

The gender action plan (GAP) for the present phase includes activities related to training in gender concepts for National Curriculum and Textbook Board (NCTB) curriculum developers, developing genderresponsive training programs and materials for teachers, promoting science education for girls by introducing practical science teaching in schools, providing science equipment and other teaching equipment including map and charts to selected schools and madrasas. It also includes activities related to ensuring minimum standard of school infrastructure to include safe and gender friendly environment including guidelines in the terms of reference of construction and supervision consultants, and to encourage women's participation in construction work. Finally, it includes activities related to developing gender indicators on the baseline, progress, and evaluation of secondary education performance, and updating them with sexdisaggregated data.

Another completed project in secondary education, the Secondary Education Sector Development Program, ${ }^{190}$ which included a project and a program loan, also reinforces the same lesson on reform taking time. ${ }^{191}$

\footnotetext{
189 ADB. 2013. MFF Facility Concept: Secondary Education Sector Investment Program. Manila (Project 44213-016-BAN).

190 ADB. 2015. Secondary Education Sector Development Program. Manila (Project 37307-013BAN).

191 The project loan was signed on 8 November 2006, and the loan closed on 30 June 2013. The program loan was approved on 26 October 2006. The loan agreement was signed on 8 November 2006, and the loan closed on 30 September 2009.
}

The goal of the program and project loans was to help reduce poverty in Bangladesh by making secondary education more relevant to the needs of the labor market. The major development purpose was to continue the series of policy reforms initiated under the Secondary Education Improvement Project. The project completion report notes, "The project made significant impact on the education sector in general and secondary education subsector in particular in terms of increased relevance of secondary education to the demands of the labor market, poverty reduction, institutional development, improvement of gender issues, and economic and social development."192 One lesson was that implementing reforms under a project loan is generally difficult and less effective in accomplishing outcome than having a dedicated separate program loan meant for pursuing reforms. ${ }^{193}$

Targets, if set realistically, can be an important strategic tool to ensure gender is mainstreamed in the project. This was an important lesson learned from the Teaching Quality Improvement in Secondary Education (TQI-1) Project, which was followed by the second project (TQI-2), a GEN category follow-up project (from 4 December 2006 to 31 December 2015) to enhance the quality of learning in secondary school classrooms through better teaching. ${ }^{194}$ This was to be achieved through upgrading the skills, knowledge, and competencies of teachers, head teachers, and teacher educators by enhancing the learning environment in schools and strengthening institutions to support the professionalism of teaching. The focus was to increase the number of female teachers to encourage more equality in education. The central aspiration of the project was to achieve a positive symbiotic relationship between improved quality of education and the increasing participation of female teachers.

192 ADB. 2015. Completion Report: Secondary Education Sector Development Program in Bangladesh. Manila (Project 37307-013-BAN). p. 13.

193 Footnote 192 (Completion Report: Secondary Education Sector Development Program in Bangladesh). p. 14.

194 ADB. 2006. Secondary Education Sector Improvement Project. Manila (Project 30332-013BAN). The information provided in this section is based on the validation report on the stated project approved in November 2015. 
An important aspect of the project GAP was achieving the target of $30 \%$ representation of women teachers at secondary schools. Various project activities and tasks were undertaken including improving sexdisaggregated data on teachers; improving the availability of accommodation for women teachers; attracting women to training and employment in shortage subjects; setting targets for women in TQI training; promoting awareness among school management committees (SMCs), head teachers, and communities about the government target for recruitment of female teachers; and strategic planning workshops for education and administrative officials to promote adherence to the targets and the development of action plans to achieve them.

Since the project has been on the ground, women's participation has been encouraged and ensured by a circular in 2009 for the appointment of at least two women members in SMCs. However, experience has shown that increasing number of women is not enough; there has to be more follow-up training on gender and inclusive education for SMCs, particularly given the likely turnover with elections to SMCs every third year. A challenge that was not identified at the TQI planning stage was the need for measures to protect girl students and female teachers from sexual harassment and intimidation. In response, a community orientation on Zero Tolerance towards the Violation of the Rights of Girl Students and Women Teachers was carried out. ${ }^{195}$

Given the difference between the target and the current results, it will take some years to achieve the targets even with a high and steady rate of recruitment of female teachers. In such cases, targets can be set in phases, i.e., with milestones to be achieved by particular dates. The significant reduction in targets highlights some points about the use of targets. ${ }^{196}$ Any target established must be reasonable and achievable if it is to remain credible.

195 ADB. 2014. Completion Report: Teaching Quality Improvement in Secondary Education Project in Bangladesh. Manila (Project 26061-BAN).

196 The target was subsequently revised by government circular and in the GAP to $40 \%$ in urban areas, $20 \%$ in rural areas, and "relaxed" in remote and underserved areas (equivalent to a $23 \%$ overall target)
Establishing a reasonable and achievable target requires data and analysis. For example, what is reasonable and achievable as a target for women's representation in secondary teaching positions would be affected by current representation of women in those positions, supply-side barriers, demand-side barriers (factors affecting school or community decisions to hire or keep women teachers), and strategy to address barriers (specific steps to be taken and resources allocated).

Secondary education has to be relevant to the demands of the labor market as well as social needs. ADB-facilitated interventions have supported the Government of Bangladesh in increasing the relevance of secondary education to the demands of the labor market, poverty reduction, institutional development, gender equality and social inclusion, and economic and social development. There has been a great deal of effort to make the secondary education system, of which a portion is related to skills and vocational education, more responsive to the needs and priorities of women and girls. There is a better understanding of the gaps and barriers to be addressed. The Secondary Education Sector Investment Program (Tranche 2), an ongoing investment program (from January 2014 to December 2017) categorized as GEN, supports the government's reform of secondary education (grades 6-12) into a system that builds the foundation for a skilled labor force and prepares youth to meet the requirements of a rapidly developing economy. It supports advanced teaching and learning programs that use ICT, as well as prevocational and vocational programs, teacher development, and examination reforms. It promotes gender equitable and pro-poor stipends for students. Market relevant and socially inclusive skills development contents have been added in the curriculum.

The GAP for the present phase also includes activities related to training in gender concepts for NCTB curriculum developers, developing gender-responsive training programs and materials for teachers, promoting science education for girls by introducing practical science teaching in schools, providing science equipment and other teaching equipment including 
map and charts to selected schools and madrasas. It also includes activities related to ensuring minimum standard of school infrastructure to include safe and gender-friendly environment including guidelines in the terms of reference of construction and supervision consultants and to encourage women's participation in construction work. Similar to the Secondary Education Sector Investment Program, it includes activities related to developing gender indicators on the baseline, progress, and evaluation of secondary education performance, and to updating them with sex-disaggregated data.

Through another completed project, the Secondary Education Sector Improvement Project, the government recognized the need for a reoriented secondary education system that is relevant to the country's growing formal markets as well as social needs. According to the project completion report, important lessons learned from the project were as follows: (i) reforms of the education sector including gender-related reforms require a long implementation period, persistent pursuit of reform agenda, and continued budgetary support to accomplish targeted improvements; (ii) the school-based management approach helps utilize hands-on training support for teachers, new facilities, and equipment provided to schools; and (iii) effective school leadership is required to bring significant changes to school management and performance, and is critical for leadership to support gender reforms.

\section{- Skills Development and Technical and Vocational Education and Training Subsector}

Encouraging more women to participate is not enough. An important lesson from the MFF Skills Employment Investment Program (Tranche 1 and Tranche 2) is that simply encouraging more women to participate in the TVET program is not enough to integrate women and girls into TVET institutions. ${ }^{197}$ Targeted interventions are needed on the supply side, i.e., more awareness building needs to be done with the industries, priority sector associations,

\footnotetext{
197 ADB. 2014. Bangladesh. MFF Facility Concept: Skills for Employment Investment Program. Manila (Project 42466-014-BAN).
}

and decision makers. On the demand side, it is not enough to train women in managerial skills in the garments industry, for example; unless the factory owners are willing to recruit women as supervisors, women will not be able to break the glass ceiling. There needs to be a holistic approach to ensuring more women are entering TVET programs and are also being placed in nontraditional, high-skilled, and better-paid jobs in priority sectors. This must involve targeted training for women, building a conducive environment for women to work in higherpaid jobs and working at the policy level to ensure strategic approaches are adopted and implemented by the government to move the agenda forward.

The MFF Skills Employment Investment Program has integrated some key gender features to ensure women are better mainstreamed into the TVET sector. Targets and activities included in the project that focus on women and girls are (i) ensuring that more women are entering the TVET programs (at least 78,000 women trainees certified) and receiving financial support through schemes to continue in the program, especially women from poor and disadvantaged communities; (ii) integrated specific strategies and activities to ensure trained women are placed in relevant and mid-level jobs in selected priority sectors; (iii) targeted interventions designed to ensure women are gradually streamlined in nontraditional, technical, and high-skilled trades instead of the gender stereotyped jobs and industries; (iv) within the TVET system and institutions, build capacity of women to take a proactive role in the different committees and lead some of the interventions and institutions within TVET; and (v) build capacity of women staff and faculty in TVET institutions in general.

While the number of women entrants in TVET has increased significantly as a result of the ongoing and past skills development projects and the government's commitment to integrate more women into the programs, one of the key challenges that still remains is enrolling women into mid to high levels skilled trades within TVET. While efforts toward reducinggender gaps in skills training has been ongoing through government policies and actions and development sector interventions, and has resulted in increased 
women participation in the job market, in reality women have fewer opportunities than men and this vicious cycle persists in the job market. Also, while more women staff are recruited into the TVET structures and intuitions, recruitment of women in managerial and decision-making post is still a challenge.

Encouraging girls and women requires more efforts. Another lesson is that encouraging girls and women in the TVET sector needs a very systematic gender responsive policy, strategic approaches, and skilled professionals. This was learned through the Skills Development Project supported by ADB and the Swiss Agency for Development Cooperation (from June 2008 to June 2015). ${ }^{198}$ The project's outcome was strengthened TVET capacity to provide market-responsive, shortterm relevant skills training through four outputs: (i) enhanced relevance and access of TVET program, (ii) improved capacity for good quality TVET delivery, (iii) relevant skills training delivered, and (iv) project management. The information, education, and communication materials developed and used in workshops and training of teachers were useful tools for shifting the mind-set of trainees on priority occupations for women. Women friendly environment was created in eight technical teachers training colleges and vocational teachers training institutes by renovating a women's hostel and creating toilet facilities. A new girls' hostel was established at Vocational Teachers Training Institute, Bogra for increasing access to good quality and relevant skills training. The project also created awareness among the management personnel, and public and private TVET institutions about the importance of integrating gender concerns into TVET courses, and on how to create employment opportunities for women and men. In addition, the project formed the Forum of Skills Development Partners with women's participation and developed an action plan which also included women's needs and priorities.

Training does not create jobs. Another lesson is that training does not create jobs, and therefore entrepreneurship training for self-employment should be included where trainees are not ready to move into regular employment.

This project has produced an impressive set of documents on lessons to be learned for TVET and skills development. The ones relevant for GED have been reflected.

One of the central findings from the review of good practices from $\mathrm{ADB}$ and non-ADB experiences is that considerable efforts are being invested toward meaningful innovation in skills and vocational education, both in the state and non-state sectors in Bangladesh. Context-specific innovations and best practices are emerging both in urban and rural areas in Bangladesh. Such diverse efforts do not appear to have created a "critical mass" that is able to make transformative change in the domain of skills development leading to gender equality. Experience suggests that there are two major approaches for such transformative change to happen: (i) creating sound institutional mechanisms for nationwide meaningful skills delivery, and (ii) meeting the challenge of application of the skills acquired through the creation of appropriate market linkages.

\section{Strengthening Gender Equality Approaches}

This section outlines the possible actions to strengthen gender equality approaches in the skills, vocational, and tertiary education sector. Annex 1 provides a tip sheet on integrating gender perspectives in skills, vocational, and tertiary education projects. Annex 2 provides a list of useful resource materials.

198 ADB. 2008. Bangladesh. Skills Development Project. Project Number: BAN 39408-013. Manila. 


\section{Action Areas \\ Implementing Progressive Legislation \\ A. Strengthen implementation of education policies related to gender and skills. \\ B. Embed gender equity in all formal technical and vocational education and training (TVET) institutions and key instruments including the regulatory system and measures for TVET compliance. An integrated TVET policy framework is needed to promote girls' and women's access to more and better quality jobs. \\ Situating Skills Development within Continuing Education}

C. Create a synergic relationship between skills development, vocational education, and markets by seeking ways and means to extend the delivery of education within the framework of continuing education.

D. Create skills readiness by introducing skills readiness interventions even at primary levels. For instance, children could be introduced to basic tools related to vocational education through innovative and interesting means appropriate to children's psychology, emphasizing dignity of labor and breaking gender stereotypes.

\section{Making TVET Gender Responsive}

E. Consider the needs of girls and women in terms of accommodation, sanitation, transport, timing, and location to ensure a friendly environment for them for vocational education and skills development.

F. Explore strategies for on-the-job upskilling in collaboration with employers.

G. Leverage the capacity of TVET to challenge gendered social norms that impact the socioeconomic status of women and girls through, e.g., advertisements, course offerings, and job placements.

H. TVET programs and courses for women should not only include life skills and work skills, but also entrepreneurship and small business skills.

I. Promote female role models and mentors especially those working in differing occupations and industries and establish guidance and mentoring support systems for girls and working in differing occupations and industries, and guidance and mentoring support systems for girls and women during pre-training and employment.

\section{Strengthening the National Skills Development Council}

J. To address gender equality holistically, the following are needed: (i) a multidimensional strategy to address market and skills-related issues like market linkages, apprenticeship, and stipends; (ii) integration of technical skills with life skills; and (iii) ensuring working conditions. NSDC needs to progressively widen its scope by incorporating membership of stakeholders. It can support the above areas by including members of civil society, as well as by setting up a strong component of research and development wing.
Responsibility

Ministry of Education (MOE), Ministry of Women and Children Affairs (MOWCA)

MOE, MOWCA

MOE, nongovernment organizations (NGOs),

private sector

National Curriculum and Textbook Board (NCTB), MOE, International Labour Organization (ILO), United Nations Children's Fund (UNICEF)

Technical and Vocational Education and Training (TVET) and skills providers in public sector, private sector, and NGOs

Ministry of Labour and Employment, MOE, Ministry of Industries, employers' associations and labor unions and associations

TVET and skills providers in public sector, private sector, and NGOs

TVET and skills providers in public sector, private sector, and NGOs

TVET and skills providers in public sector, private sector, and NGOs

National Skills Development Council (NSDC), NGOs 


\section{Action Areas}

K. Assign a gender focal point within NSDC, who will address gender as a cross-cutting theme and work closely with industry skills councils and informal education committees within NSDC.

L. Strengthen the capacity of the national statistical system, ministries, and the private sector in generating and reporting skills-related data disaggregated by sex.

\section{NGO and Private Sector Role in Skills Development and TVET}

M. Encourage NGOs to reorganize and redefine their future development initiatives in skills training in line with market forces; develop capacity to provide necessary market-driven skills for self-employment; and create institutional linkages to help women acquire higher vocational skills for wage and selfemployment, including in the formal sector.

N. Recognize and support private sector initiatives in technical and vocational education, as they are more likely to be attuned to market needs and have unused capacity

\section{Promoting Women's Entrepreneurship and Migration}

O. Promote and support increased women's economic participation in small-scale entrepreneurship through various incentives and support for access to markets and finances, monitoring of workplace safety measures, and provision of childcare support. Appropriate vocational and technical education could also be provided, while ensuring safety and security.

P. Rural women's entrepreneurship in the form of selfemployment will require different kind of training, financing, and management. Orientation on entrepreneurship including management of finances could be included in the secondary school curriculum and as a part of continuing education.

Q. Strengthen government initiatives for providing skills development in care giving and hospitality (particularly in the European countries where there is high demand for caregivers for old people), and other areas identified according to international market demand. This would facilitate higher value female labor migration from Bangladesh in higher skill areas.
Responsibility

NSDC

NSDC, MOE, MOWCA, Bangladesh Bureau of Statistics (BBS), and private sector

NSDC, NGOs, MOE

NSDC, MOE

NSDC; NGOs; Bureau of Manpower, Employment and Training (BMET); technical training centers (TTCs)

NCTB, NGOs, NSDC, Palli Karma-Sahayak

Foundation (PKSF), Bangladesh Academy for Rural Development (BARD)

BMET, NGOs, Ministry of Expatriates' Welfare and Overseas Employment

\section{Increasing Number and Representation of Women in Tertiary Education}

R. Create interest and motivation for girls and women to enter technical and scientific subjects and fields through campaigns in the media and education institutions.

S. Introduce entry quotas to technical universities for women and provide job counseling and job fairs as well as internships with private sector to enable them to find employment on completion.

T. Provision of financial support for the poor girls and women, quality improvement of education, development of genderbalanced curricula, and promotion of girl-friendly educational institutions could be implemented to address the barriers for girls and women to access tertiary education.
All stakeholders including Government of Bangladesh (GoB)

University Grants Commission (UGC), MOE

NCTB, MOE, UGC 
Table continued

\begin{tabular}{|l|l|}
\hline Action Areas & Responsibility \\
\hline $\begin{array}{l}\text { U. Increase number of women as teachers and managers in } \\
\text { tertiary education through institutional measures such as } \\
\text { clear institutional policies and grievance mechanisms, as } \\
\text { well as social infrastructure and strong advocacy in favor of } \\
\text { gender equality. }\end{array}$ & MOE, UGC \\
\hline $\begin{array}{l}\text { V. Review policies on recruitment and selection of senior leaders } \\
\text { and managers for more transparency and accountability. } \\
\text { Investment in women's capacity building is essential in all } \\
\text { countries. This includes research-informed, women-only } \\
\text { leadership development programs; access to doctoral degrees; } \\
\text { and training and continuous professional development } \\
\text { opportunities, mentorship programs, and networks. }\end{array}$ & MOE, UGCional University \\
\hline
\end{tabular}




\section{Annex 1: Tip Sheet on Questions and Design Features for Gender Mainstreaming in Skills, Vocational, and Tertiary Education Projects}

\begin{tabular}{|c|c|c|}
\hline $\begin{array}{l}\text { Illustrative outcomes of projects } \\
\text { and related possible gender } \\
\text { equality outcomes }\end{array}$ & $\begin{array}{l}\text { Examples of questions to consider } \\
\text { in analyses to formulate project } \\
\text { strategies and gender-related } \\
\text { design features }\end{array}$ & $\begin{array}{l}\text { Examples of possible gender-related } \\
\text { design features, measures, and activities } \\
\text { that might be relevant (or adaptable) }\end{array}$ \\
\hline \multicolumn{3}{|c|}{ Creating enabling policy environment } \\
\hline $\begin{array}{l}\text { Policy and institutional } \\
\text { framework creates a favorable } \\
\text { environment for state and non- } \\
\text { state stakeholders to address } \\
\text { gender equity in skills, vocational, } \\
\text { and tertiary education. }\end{array}$ & $\begin{array}{l}\text { What are the policy gaps in relation } \\
\text { to women's needs and interests? } \\
\text { - How to make policy more } \\
\text { transformative for women? } \\
\text { - Are there policy provisions } \\
\text { regarding gender mainstreaming in } \\
\text { education and skills that can be used } \\
\text { to justify action proposed? }\end{array}$ & $\begin{array}{l}\text { - National dialogue for aligning } \\
\text { internationally acknowledged gender } \\
\text { dimensions with national policies and } \\
\text { strategies needed } \\
\text { - Identification of present policy provisions } \\
\text { that promote greater involvement of } \\
\text { women and girls in skills, vocational, and } \\
\text { tertiary education } \\
\text { - Developing policy monitoring and } \\
\text { accountability mechanisms that would } \\
\text { include women and girls as stakeholders }\end{array}$ \\
\hline $\begin{array}{l}\text { Existing policies and provisions } \\
\text { for women's entrepreneurship } \\
\text { should be aligned with education } \\
\text { and skills development policies } \\
\text { so that the area of skills for } \\
\text { entrepreneurship is supported. }\end{array}$ & $\begin{array}{l}\text { What are the areas of skill gaps for } \\
\text { women's entrepreneurship in both } \\
\text { urban and rural areas? } \\
\text { - What are the skill gaps for different } \\
\text { age groups and sectors? } \\
\text { - Where and how are skills training } \\
\text { provided? Is it appropriate for } \\
\text { women entrepreneurs? }\end{array}$ & $\begin{array}{l}\text { - Market research on demand for } \\
\text { training by women entrepreneurs and } \\
\text { identification of areas of unserved needs } \\
\text { - Scoping of training available for women } \\
\text { entrepreneurs and identification of gaps } \\
\text { - Identification of private sector, } \\
\text { nongovernment organization, and } \\
\text { government providers of training and on- } \\
\text { the-job support for women entrepreneurs }\end{array}$ \\
\hline \multicolumn{3}{|c|}{ Increasing responsiveness to markets } \\
\hline $\begin{array}{l}\text { Secondary, tertiary, and vocational } \\
\text { education are more responsive } \\
\text { to market needs and gender } \\
\text { considerations. }\end{array}$ & $\begin{array}{l}\text { - Where are women situated in the } \\
\text { labor market currently? } \\
\text { - Where are potential areas for } \\
\text { women to enter? } \\
\text { - Are there good examples of } \\
\text { nontraditional and potential } \\
\text { occupations for women that can be } \\
\text { adopted from the region? } \\
\text { - What are the constraints for women } \\
\text { to enter and stay in better-paid and } \\
\text { more productive occupations? }\end{array}$ & $\begin{array}{l}\text { - Developing partnerships with employers' } \\
\text { associations and trade unions } \\
\text { - Carrying out market surveys of demand } \\
\text { for labor } \\
\text { - Media campaigns to challenge stereotypes } \\
\text { on occupational segregation } \\
\text { - Skills development to be supplemented by } \\
\text { job placements and job counseling }\end{array}$ \\
\hline
\end{tabular}


Annex 1 continued

\begin{tabular}{|c|c|c|}
\hline $\begin{array}{l}\text { Illustrative outcomes of projects } \\
\text { and related possible gender } \\
\text { equality outcomes }\end{array}$ & $\begin{array}{l}\text { Examples of questions to consider } \\
\text { in analyses to formulate project } \\
\text { strategies and gender-related } \\
\text { design features }\end{array}$ & $\begin{array}{l}\text { Examples of possible gender-related } \\
\text { design features, measures, and activities } \\
\text { that might be relevant (or adaptable) }\end{array}$ \\
\hline $\begin{array}{l}\text { Women equipped with higher } \\
\text { value skills are suitable for } \\
\text { international labor markets. }\end{array}$ & $\begin{array}{l}\text { - How can overseas employment } \\
\text { be made more safe and secure by } \\
\text { encouraging migration for skilled } \\
\text { and formal employment? } \\
\text { - What are the skill areas and } \\
\text { professions with potential for } \\
\text { migration? And in which countries? }\end{array}$ & $\begin{array}{l}\text { Market research on demand for skilled } \\
\text { female migrants } \\
\text { - Changes to the regulatory framework for } \\
\text { migration to allow women to migrate in } \\
\text { other categories than at present } \\
\text { - Vocational training institutes and } \\
\text { programs equipped and trained to provide } \\
\text { training in new areas identified }\end{array}$ \\
\hline \multicolumn{3}{|c|}{ Increasing participation of women and girls } \\
\hline $\begin{array}{l}\text { Participation of women and girls } \\
\text { in secondary and vocational } \\
\text { education should be increased. }\end{array}$ & $\begin{array}{l}\text { - How can vocationalization of } \\
\text { secondary education be used to } \\
\text { ensure greater participation of } \\
\text { women and girls? } \\
\text { - What are the barriers to women } \\
\text { and girls availing of secondary and } \\
\text { vocational education? } \\
\text { - How can security, accommodation, } \\
\text { and timing of courses be adapted to } \\
\text { the needs of women and girls? } \\
\text { - How can entry requirements } \\
\text { be adjusted to ensure school } \\
\text { dropout girls and boys can have } \\
\text { access to training? }\end{array}$ & $\begin{array}{l}\text { - Review of residential facilities and } \\
\text { location of vocational institutes and } \\
\text { training programs } \\
\text { - Review of entry requirements } \\
\text { - Preparation of action plan to address } \\
\text { entry and retention barriers } \\
\text { - Developing closer relations with private } \\
\text { sector employers for job placements }\end{array}$ \\
\hline
\end{tabular}




\section{Annex 2: Useful Resources for Further Reading on Gender Equality in Skills, Vocational, and Tertiary Education}

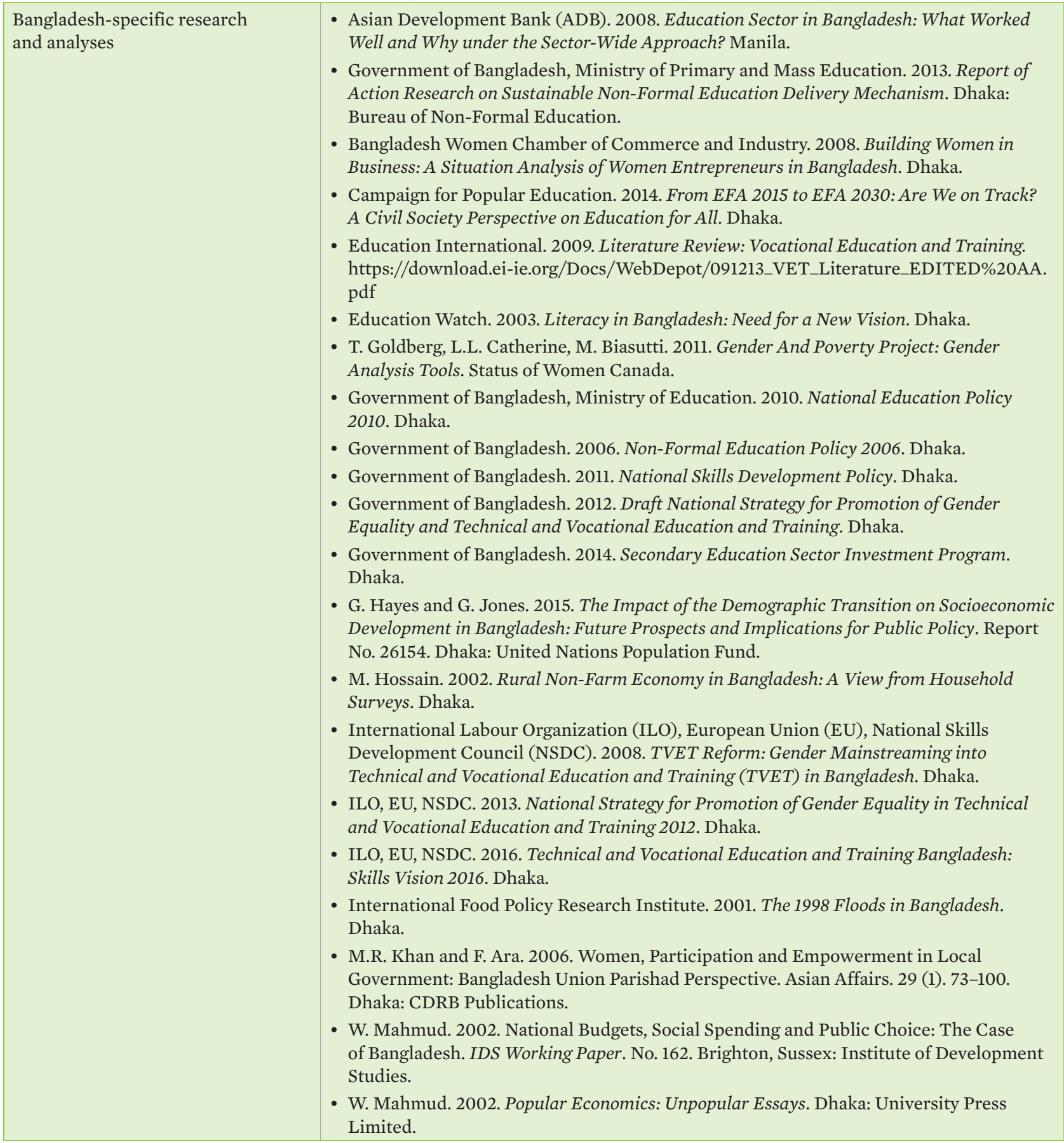

continued on next page 
Annex 2 continued

\begin{tabular}{|c|c|}
\hline & $\begin{array}{l}\text { P.P. Majumder. 2005. National Education Budget for Bangladesh and Women } \\
\text { Empowerment. Dhaka: Bangladesh Nari ProgatiSangha and Institute for Environment } \\
\text { and Development. } \\
\text { - Maxwell Stamp. 2001. Review of Relative Protection. Prepared for the Bangladesh Tariff } \\
\text { Member Countries, Federation of Bangladesh Chambers of Commerce and Industry } \\
\text { (FBCCI), Dhaka. } \\
\text { - United Nations Children's Fund. 2011. A perspective on gender equality in Bangladesh: } \\
\text { From young girl to adolescent: What is lost in Transition? Analysis based on selected } \\
\text { results of the Multiple Indicator Cluster Survey 2009. Dhaka. } \\
\text { - United Nations Population Fund. 2015. The Impact of the Demographic Transition on } \\
\text { Socioeconomic Development in Bangladesh: Future prospects and Implications for } \\
\text { Public Policy. Background paper prepared for the Bangladesh Planning Commission of } \\
\text { the General Economics Division in support of the development of the 7th Five-Year Plan } \\
\text { 2016-2020. The United Nations Population Fund, Bangladesh Country Office. Dhaka. } \\
\text { - World Bank, 2003. Bangladesh - Development Policy Review: Impressive Achievements } \\
\text { but Continuing Challenges, World Bank Other Operational Studies 14669, The World } \\
\text { Bank. }\end{array}$ \\
\hline Other research and analyses articles & $\begin{array}{l}\text { C. Chappell. 2003. Researching Vocational Education and Training: Where to Go from } \\
\text { Here? Journal of Vocational Education and Training. } 55 \text { (1). pp. 21-32. } \\
\text { - Y. Cho et al. 2013. Gender Differences in the Effects of Vocational Training: Constraints } \\
\text { on Women and Drop-out Behavior. Policy Research Working Paper. No. WPS } 6545 . \\
\text { Washington, DC: World Bank. } \\
\text { - F. Chowdhury. 2007. Customized Form of Finance for SMEs, Seminar Proceedings. } \\
\text { Dhaka: FBCCI. } \\
\text { - A. Mikkola. 2005. Role of Gender Equality in Development-A Literature Review. } \\
\text { Discussion Paper. No. 84. Helsinki Center of Economic Research. } \\
\text { - United Nations Educational, Scientific and Cultural Organization (UNESCO). } 2010 . \\
\text { Gender Issues in Higher Education. Bangkok: UNESCO Asia and Pacific Regional Bureau } \\
\text { for Education. }\end{array}$ \\
\hline Guides and case studies & $\begin{array}{l}\text { - Y. Hayami. 1998. Toward the Rural-Based Development of Commerce and Industry: } \\
\text { Selected Experiences from East Asia (Ed.), World Bank, EDI Learning Resource Series, } \\
\text { Washington, DC. } \\
\text { - R.H. Khan, A.M. Mridha, and S. Barua. 2009. Women Entrepreneurs in SMEs: } \\
\text { Bangladesh Perspective. Dhaka. } \\
\text { - C. March, I. Smyth, and M. Mukhopadhyay. 1999. A Guide to Gender-Analysis } \\
\text { Frameworks. Oxfam. } \\
\text { - A. Mikkola. 2005. Role of Gender Equality in Development-A Literature Review. } \\
\text { University of Helsinki, RUESG, and HECER. Discussion Paper No. 84. ISSN 1795-0562. }\end{array}$ \\
\hline $\begin{array}{l}\text { ADB practical resources for project } \\
\text { planning and management in } \\
\text { the sector }\end{array}$ & $\begin{array}{l}\text { - ADB and UN. 2014. BHUTAN: Gender Equality Diagnostic of Selected Sectors. Manila. } \\
\text { - ADB. 2001. Special Evaluation Study on Gender and Development. Manila. } \\
\text { - ADB. 2002. Interim Progress Report on the Policy on Gender and Development. Manila. } \\
\text { - World Bank. 2004. Bangladesh: Gender, Poverty, and the Millennium Development Goals: } \\
\text { Country Gender Strategy. Washington. https://www.openknowledge.worldbank.org/ } \\
\text { handle/10986/14669?show=full } \\
\text { - ADB. 2006. Gender, Law, and Policy in ADB Operations: A Tool Kit. Manila. https://www } \\
\text {.adb.org/documents/gender-law-and-policy-adb-operations-tool-kit } \\
\text { - ADB. 2009. Project Gender Action Plans: Lessons for Achieving Gender Equality and } \\
\text { Poverty Reduction Results. Manila. https://www.adb.org/publications/project-gender- } \\
\text { action-plans-lessons-achieving-gender-equality-and-poverty-reduction } \\
\text { - ADB. 2010. Bangladesh: Second Participatory Livestock Development Project. Manila. } \\
\text { - ADB. 2010. Basic Statistics 2010. Manila. } \\
\text { - ADB. 2011. Country Partnership Strategy: Bangladesh, 2011-2015. Manila. } \\
\text { - ADB. 2013. Facility Administration Manual: Bangladesh: Secondary Education Sector } \\
\text { Investment Program. Manila (Project 44213). }\end{array}$ \\
\hline
\end{tabular}


- ADB. 2013. Gender Equality in the Labor Market in Cambodia. Manila.

- ADB. 2014. Tool Kit on Gender Equality Results and Indicators. Manila.

- ADB. 2015. Bangladesh Gender Equality Results: Case Study Small and Medium-Sized Enterprise Development Project. Manila.

- F.S. Begum. 2014. Gender Equality and Women's Empowerment: Suggested Strategies for the 7th Five Year Plan. General Economics Division, Planning Commission, Government of Bangladesh.

- Bangladesh Institute of Development Studies. 2010. Recent Performance of the Bangladesh Economy - An Assessment of the State of the Economy and Short-Term Outlook 2009-10. Dhaka.

- ADB. 2003. Gender Checklist: Resettlement. Manila. https://www.adb.org/publications/ gender-checklist-resettlement

- Further resources and guides on gender action plans: www.adb.org/themes/gender/ project-action-plans 


\section{Bangladesh Gender Equality Diagnostic of Selected Sectors}

Over the last 2 decades, Bangladesh has made progress in women's participation in the labor force, gender parity in primary education, and women's political representation. Areas of concern include the high prevalence of violence against women, obstacles to women's access to resources and assets, unequal terms of their labor engagement, and impact of their overwhelming responsibility for care work. The Government of Bangladesh has made policy commitments toward gender equality and established an institutional framework to fulfill these. This publication intends to support the government in its attempt to address persisting gender inequalities and gaps through a multisector approach across policies, programs, and projects. It provides insights into gender issues in urban; transport; energy; and skills, vocational, and tertiary education, and gives suggestions for strengthening gender mainstreaming in projects.

\section{About the Asian Development Bank}

ADB's vision is an Asia and Pacific region free of poverty. Its mission is to help its developing member countries reduce poverty and improve the quality of life of their people. Despite the region's many successes, it remains home to a large share of the world's poor. ADB is committed to reducing poverty through inclusive economic growth, environmentally sustainable growth, and regional integration.

Based in Manila, ADB is owned by 67 members, including 48 from the region. Its main instruments for helping its developing member countries are policy dialogue, loans, equity investments, guarantees, grants, and technical assistance.

\section{ASIAN DEVELOPMENT BANK}

